Mariana Chiesa Gouveia Nascimento

\title{
REGULARIZAÇÃO FUNDIÁRIA URBANA DE INTERESSE SOCIAL NO DIREITO BRASILEIRO
}

Dissertação apresentada ao Departamento de Direito do Estado como exigência para obtenção do título de Mestre em Direito.

Orientação: Professor Associado Floriano de Azevedo Marques Neto

Faculdade de Direito da Universidade de São Paulo São Paulo, 2013 


\section{AGRADECIMENTOS}

Confesso que não imaginei que seria tão difícil redigir meus agradecimentos. De um lado a sensação de que um simples "obrigada" é insuficiente. De outro, a plena consciência de que não conseguirei nomear todos os que tiveram um papel merecedor de lembrança no decorrer deste trabalho. Ainda assim, tentarei destacar aqueles que foram cruciais para o desenvolvimento desta pesquisa.

Sei da redundância da afirmação de que sem o orientador este trabalho não seria possível, mas de fato tive um inestimável privilégio de ter sido orientada pelo Professor Floriano de Azevedo Marques Neto. Durante os três anos em que a presente temática foi maturada, estruturada, redigida, completada e corrigida, a cada passo, a sempre presente e cuidadosa avaliação do orientador, que não se restringiu apenas ao cumprimento de formalidades, serviram como verdadeira inspiração, repleta de conselhos perspicazes, cobranças em momentos estratégicos, pontos de vista inovadores, clareza na organização do raciocínio, enfim, ensinamentos que vão muito além da dissertação e que levarei daqui em diante.

A escolha do tema, devo à equipe do Direito à Cidade do Instituto Pólis e do Escritório Modelo da PUC-SP que me proporcionaram, não apenas a participação, ainda como estagiária, em processos de regularização fundiária de interesse social no Município de São Paulo, mas também um contato com aspectos da problemática que marcaram meu aprendizado e meu envolvimento com a política urbana. Fizeram parte desse processo apaixonante Nelson Saule Júnior, Ellade Imparato, Anna Cláudia Pardini Vazzoler, Patrícia Cardoso, Rodrigo Dantas, Kátia Hale, Caio Amore e Thais Berberian.

Os anos que passei desenvolvendo a pesquisa não poderiam ter sido melhores ao lado da equipe da Manesco. Aos sócios José Roberto Manesco, Eduardo Augusto de Oliveira Ramires, Floriano de Azevedo Marques Neto, Marcos Augusto Perez e Tatiana Matiello Cymbalista agradeço enormemente pelo aprendizado, acolhimento, compreensão e oportunidade de ter trabalhado ao lado de profissionais exemplares em projetos inovadores que permitiram diferentes abordagens para a presente pesquisa. Aos dois últimos sou também muito grata pela amizade que o dia a dia mais próximo proporcionou. Agradeço às amigas Marina Fontão Zago, Maís Moreno, Fernanda Esbizaro Rodrigues e 
Marina Cardoso, que acompanharam dia a dia este processo, sempre com palavras carinhosas de incentivo. Obrigada também às secretárias, Isabel Cristina Fernandes Bossato, Silvia de Souza, Regina Pereira Silva e Eliane Cristina Bozo sem as quais as angústias teriam sido bem maiores.

Ao grupo do Centro de Estudos de Direito Administrativo, Ambiental e Urbanístico (CEDAU) agradeço, em nome da Professora Titular Odete Medauar, pela qualidade das discussões e atualidade dos debates que trouxeram novos ares para a pesquisa.

Agradeço também ao Danilo Tavares da Silva, pela amizade incondicional, pelo aprendizado e pela inabalável participação, repleta de auxílios e aconselhamentos, que se iniciou com o estímulo para prestar o mestrado nesta universidade e incluiu até doação de livros relacionados ao tema; à Juliana Bonacorsi de Palma, pelo companheirismo, qualidade das intervenções, disponibilidade em ajudar e cuidadosa leitura da qualificação e do trabalho final; ao Vitor Rhein Schirato, pela contribuição na formulação do trabalho e em seu desenrolar; e à Ágata Bobbio Ferraz, pelo carinhoso apoio e leitura do trabalho final.

Às amigas, Priscila Cortez de Carvalho, Laura Borges, Maria Cláudia Cruz de Oliveira e Fernanda Ribeiro, primas, Alessandra Gouveia e Maria Clara Gouveia Lopes, sogros, Maria Christina Nogueira Monteiro e Manuel Freitas Monteiro, cunhada, Marcela Nogueira Monteiro, e irmãos Bruno e Gustavo sou grata pelo suporte indireto, mas não menos importante.

Aos meus pais, Anna Maria Chiesa e Roberto Gouveia Nascimento, agradeço pelo amor, carinho, cobrança, participação constante como leitores atentos, ainda que o contato deles com a Lei tenha se dado em outra ordem, e pela vinculação visceral às causas sociais que marca a história de ambos e são uma inspiração de vida para mim.

Por fim, agradeço ao meu companheiro Felippe Nogueira Monteiro que cuidou passo a passo da minha trajetória com um olhar crítico, mas sempre amoroso, ajudando-me na escolha dos caminhos, desde a iniciação científica até a mudança de país, e, nesta etapa final, além de ter me proporcionado o tempo necessário para desenvolver a dissertação, tornou este período a melhor experiência de nossas vidas, trazendo a uma fase repleta de angústia, muito carinho, parceria, novidades, bom humor, sossego. Enfim, ao seu lado posso dizer que foi, senão mais fácil, certamente mais feliz. 
"Eu arranjei o meu dinheiro/Trabalhando o ano inteiro/Numa cerâmica/ Fabricando potes e lá no alto da Moóca/Eu comprei um lindo lote dez de frente e dez de fundos/Construí minha maloca/Me disseram que sem planta/Não se pode construir/Mas quem trabalha tudo pode conseguir/ João Saracura que é fiscal da Prefeitura/Foi um grande amigo, arranjou tudo pra mim/Por onde andará Joca e Matogrosso Aqueles dois amigos/Que não quis me acompanhar/Andarão jogados na avenida São João/Ou vendo o sol quadrado na detenção/Minha maloca, a mais linda que eu já vi /Hoje está legalizada ninguém pode demolir/Minha maloca a mais deste mundo/Ofereço aos vagabundos/Que não têm onde dormir" (Adoniran Barbosa. Abrigo de Vagabundos, 1958) 


\section{RESUMO}

O objetivo desta dissertação é examinar o instituto da regularização fundiária urbana de interesse social como alternativa apta a contribuir para que a Administração Pública cumpra com os objetivos da política urbana no sentido de garantir o pleno desenvolvimento das funções sociais da cidade e da propriedade urbana, sem deixar de destacar as problemáticas que envolvem a adoção do mecanismo. Para tanto, o trabalho parte da conceituação da expressão adotada, tendo como referência principalmente a Lei federal de Parcelamento do Solo - Lei ${ }^{\circ}$ 6.766/1979, o Estatuto da Cidade - Lei federal $n^{\circ}$ 10.257/2001; e a Lei do Programa Minha Casa, Minha Vida - Lei federal n 11.977/2009, bem como os fundamentos jurídicos que justificam sua aplicação. Para compreender alguns aspectos da relação entre o Estado e o surgimento e aplicação do instituto objeto do trabalho, recebe relevo a abordagem histórica acerca da proliferação do acesso irregular ao solo urbano, bem como a forma de organização interfederativa pós Constituição Federal de 1988, tanto para regular quanto para executar medidas abrangidas no objeto do estudo. A compreensão da amplitude do instituto é reforçada por meio da apresentação do extenso rol de instrumentos jurídicos encontrados no ordenamento jurídico, considerando a amplitude conceitual adotada. Com relação à escassez de recursos públicos para a implementação do instituto, o trabalho identifica arranjos contratuais que podem contribuir para a viabilização de investimentos a serem aplicados em projetos de regularização fundiária urbana de interesse social. Por fim, a pesquisa aponta problemáticas internas e externas que podem ser extraídas do instituto, analisando criticamente os aspectos que envolvem a sua necessidade, utilidade e efetividade.

Palavras-Chave: política urbana, moradia, função social da propriedade, regularização fundiária urbana de interesse social. 


\begin{abstract}
This dissertation intends to analyze an urban policy instrument called the 'Urban Social Interest Land Regularization' in Brazil as an alternative tool to be used by government to achieve urban policy goals so as to ensure the full development of the social functions of the city and urban property. For this proposal, the essay begins with the definition of the expression based on three federal legislations and the constitutional basis for its use: Law $\mathrm{n}^{\circ}$ 6.766/1979; Law $\mathrm{n}^{\circ}$ 10.257/2001; and Law $\mathrm{n}^{\circ}$ 11.977/2009. To understand the relationship between the State and the instrument, the research investigates the historical approach on the proliferation of irregular access to urban land, as well as the federative organization form post-1988, both for regulatory and enforcement activity covered in the object of study. Understanding the magnitude of the institute is reinforced through the presentation of the long list of legal instruments found in the legal system. Regarding the scarcity of public resources for the implementation of the institute, the work identifies contractual arrangements that can contribute to the viability of investments to be invested in projects of Urban Social Interest Land Regularization in Brazil. Finally, the study identifies internal and external problems that can be extracted from the institute, critically analyzing the aspects involving its need, usefulness and effectiveness.
\end{abstract}

Keywords: urban policy, dwelling, social function of property, urban social interest land regularization. 


\section{LISTA DE ABREVIATURAS}

APP - Área de Preservação Permanente

BNH - Banco Nacional da Habitação

CDRU - Concessão de Direito Real de Uso

CEPAC - Certificados de potencial adicional de construção

CF - Constituição Federal

CUEFM - Concessão de Uso Especial para Fins de Moradia

EC - Emenda Constitucional

FNHIS - Fundo Nacional de Habitação de Interesse Social

FNS - Fundo Nacional de Saúde (FNS)

FUNDEB - Fundos de Manutenção e Desenvolvimento da Educação Básica e de

Valorização dos Profissionais da Educação

IBGE - Instituto Brasileiro de Geografia e Estatística

MP - Medida Provisória

ONU - Organização das Nações Unidas

PAC - Programa de Aceleração do Crescimento

PAIH - Plano de Ação Imediata para Habitação

PLANHAP - Plano Nacional de Habitação Popular

PPP - Parceria Público-Privada

PREZEIS - Plano de Regularização da ZEIS

PROFILURB - Programa de Financiamento de Lotes Urbanizados

PROHAP - Programa de Habitação Popular

SFH - Sistema Financeiro da Habitação

SNHIS - Sistema Nacional de Habitação de Interesse Social

SPU - Secretaria do Patrimônio da União

STF - Supremo Tribunal Federal

ZEIS - Zona Especial de Interesse Social 


\section{SUMÁRIO}

INTRODUÇÃO

\section{CAPÍTULO I}

REGULARIZAÇÃO FUNDIÁRIA URBANA DE INTERESSE SOCIAL 16

1.1 Fundamentos 18

1.1.1 Regularização fundiária e função social da propriedade urbana $\quad 19$

1.1.2 Regularização fundiária e direito à moradia 26

1.2 Abrangência: regularização fundiária, domínio da terra e urbanização 28

1.2.1 Lei federal $n^{\circ}$ 6.766/1979 - Parcelamento do Solo Urbano 29

1.2.2 Lei federal $\mathrm{n}^{\circ}$ 10.257/2001 - Estatuto da cidade 31

1.2.3 Lei federal no 11.977/2009 - Programa Minha Casa, Minha Vida 36

1.3 Conceito adotado no trabalho 39

1.4 Síntese conclusiva do capítulo 41

\section{CAPÍTULO II}

ASPECTOS DA RELAÇÃO ENTRE O ESTADO E A REGULARIZAÇÃO FUNDIÁRIA URBANA DE INTERESSE SOCIAL 44

2.1 Histórico do acesso irregular à moradia pela população de baixa renda 44

2.2 Competências federativas da política pública de regularização fundiária urbana de interesse social

2.2.1 Competências constitucionais $\quad 58$

2.2.2 A relação interfederativa decorrente da legislação federal infraconstitucional $\quad 62$

2.3 Síntese conclusiva do capítulo 66

CAPÍTULO III

INSTRUMENTOS PARA A REGULARIZAÇÃO FUNDIÁRIA URBANA DE INTERESSE SOCIAL

3.1 Instrumentos para a regularização dominial das áreas 68

3.1.1 Áreas públicas: a afetação de bens públicos para projetos de regularização $\begin{array}{ll}\text { fundiária urbana de interesse social } & 70\end{array}$

3.1.1.1 Concessão de direito real de uso $\quad 74$

3.1.1.2 Concessão de uso especial para fins de moradia 77 
$\begin{array}{lll}3.1 .1 .3 & \text { Aforamento } & 81\end{array}$

3.1.1.4 Doação $\quad 82$

3.1.2 Áreas privadas: usucapião especial urbana $\quad 84$

3.1.2.1 Modalidade individual $\quad 87$

3.1.2.2 Modalidade coletiva $\quad 88$

3.2 Instrumentos para compatibilização dos assentamentos às normas urbanísticas $\quad 90$

3.2.1 Zona especial de interesse social 90

3.2.2 Operações urbanas consorciadas 93

3.2.3 Consórcio imobiliário 95

3.3 Instrumentos que apresentam ambas as finalidades $\quad 97$

3.3.1 Demarcação urbanística 97

3.3.1.1 Legitimação da posse $\quad 100$

$\begin{array}{ll}\text { 3.3.2 Direito de superfície } & 102\end{array}$

$\begin{array}{ll}\text { 3.3.3 Direito de preempção } & 104\end{array}$

$\begin{array}{ll}\text { 3.3.4 Desapropriação } & 105\end{array}$

$\begin{array}{ll}\text { 3.3.4.1 Desapropriação sanção } & 108\end{array}$

3.4 Peculiaridades dos processos de regularização fundiária urbana de interesse social em Áreas de Preservação Permanente - APP 111

3.5. Síntese conclusiva do capítulo 114

\section{CAPÍTULO IV}

VIABILIZAÇÃO DE INVESTIMENTOS EM PROJETOS DE REGULARIZAÇÃO FUNDIÁRIA URBANA DE INTERESSE SOCIAL 116

4.1 Aplicação de instrumentos da política urbana 117

$\begin{array}{ll}\text { 4.1.1 Operação urbana consorciada } & 117\end{array}$

$\begin{array}{ll}\text { 4.1.2 Outorga onerosa do direito de construir } & 120\end{array}$

4.2 Instrumentos do direito administrativo 122

$\begin{array}{ll}\text { 4.2.1 Repasse de recursos } & 123\end{array}$

4.2.1.1 Convênios 124

4.2.1.2 Sistema Nacional de Habitação de Interesse Social 127

$\begin{array}{ll}\text { 4.2.2 Consórcio público } & 132\end{array}$

$\begin{array}{ll}\text { 4.2.3 Parceria público-privada } & 138\end{array}$

$\begin{array}{ll}\text { 4.2.4 Concessão urbanística } & 146\end{array}$

$\begin{array}{lll}4.3 & \text { Síntese conclusiva do capítulo } & 149\end{array}$ 


\section{CAPÍTULO V}

ANÁLISE CRÍTICA DA REGULARIZAÇÃO FUNDIÁRIA URBANA DE INTERESSE SOCIAL 152

5.1 Problemáticas internas 153

$\begin{array}{lll}5.2 & \text { Problemáticas externas } & 158\end{array}$

5.2.1 A combinação de políticas preventivas $\quad 159$

5.2.2 Procedimentalização para a definição das áreas beneficiárias de processos de regularização fundiária urbana de interesse social $\quad 165$

$\begin{array}{lll}5.3 & \text { Síntese conclusiva do capítulo } & 170\end{array}$

CONSIDERAÇÕES FINAIS 172

REFERÊNCIAS 


\section{INTRODUÇÃO}

O objetivo desta dissertação é analisar criticamente o instituto da regularização fundiária urbana de interesse social como alternativa de atuação da Administração Pública na tentativa de reduzir as desigualdades sociais decorrentes da organização do espaço urbano, por meio da inclusão formal da população de baixa renda que ocupou originalmente tal espaço de maneira irregular.

Segundo dados do IBGE (Instituto Brasileiro de Geografia e Estatística), em 1960, cerca de $55 \%$ da população brasileira vivia no campo e tal realidade começou a ser modificada dez anos depois, quando a maior parte da população passou a viver nas cidades. Dados de 2000 indicam que $80 \%$ da população brasileira vive em cidades. Isso significa que, em um período de 40 anos, as cidades que tinham cerca de 36 milhões de habitantes, passaram a ter 137 milhões, perfazendo uma diferença de 106 milhões. Desses $80 \%, 26 \%{ }^{1}$ vivem em favelas ${ }^{2}$. Levantamentos mais recentes ${ }^{3}$ indicam que nos municípios acima de 100.000 (cem mil) habitantes, aqueles que concentram a maior parcela da população urbana do país, $87 \%$ afirma possuir favelas e 92,5\% alegam ter loteamentos irregulares ou clandestinos. ${ }^{4}$

Tal diagnóstico pode ser justificado a partir de dois principais fenômenos sociais: (i) êxodo rural, que culminou na proliferação dos processos informais de desenvolvimento urbano, já que as cidades não foram adaptadas para absorver a demanda por moradia ${ }^{5}$; e (ii) ausência de políticas voltadas para interromper o ciclo da ilegalidade do acesso ao solo urbano, já que uma parcela relevante da população brasileira só tem tido acesso à moradia,

\footnotetext{
${ }^{1}$ ONU - State of the World's Cities 2010/2011.

${ }^{2}$ Para o IBGE, são consideradas favelas: "aglomerado subnormal cada conjunto constituído de, no mínimo, 51 unidades habitacionais carentes, em sua maioria, de serviços públicos essenciais, ocupando ou tendo ocupado, até período recente, terreno de propriedade alheia (pública ou particular) e estando dispostas, em geral, de forma desordenada e densa” (Disponível em: http://www.ibge.gov.br/home/presidencia/noticias/noticia_visualiza.php?id_noticia=2051. Acesso em: 11 jan. 2013).

${ }_{3}^{3}$ IBGE, Perfil dos Municípios do Brasil, 2008. Apud BALBIM, Renato. Avanços recentes no quadro normativo federal da regularização fundiária. In: Planejamento e Políticas Públicas, Brasília: IPEA, 2010, ${ }^{\circ}$ 34, jan/jun, p. 290

${ }^{4}$ BALBIM, op. cit. 2010, p. 290.

${ }^{5}$ Interessante mencionar algumas razões que podem ser extraídas da legislação e do contexto histórico: (i) condições muito priores de trabalho no campo; e (ii) estímulo à migração quando da aprovação da CLT e a definição de 8 horas de jornada de trabalho nas cidades, quando a jornada no campo era de 12 horas.
} 
por meio de processos informais. ${ }^{6}$ Nesse contexto, pode-se afirmar que o território das cidades reproduz injustiças e desigualdades, vivenciadas de maneira diferente e de acordo com as peculiaridades locais. ${ }^{7}$

Reconhecendo essa problemática estrutural relacionada ao desenvolvimento urbano brasileiro $^{8}$, o instituto da "regularização fundiária de interesse social" aparece como instrumento da política urbana na legislação federal pela primeira vez apenas em 2001, no Estatuto da Cidade, e remete o intérprete automaticamente à constatação de que se trata de um mecanismo considerado apto a trazer para a legalidade uma situação fundiária irregular que possa ser identificada como de interesse social, ou seja, que tenha como público alvo a população de baixa renda.

Considerando, entretanto, que a manutenção da precariedade da moradia associada às ocupações que se dão de forma irregular se caracteriza pela incompatibilidade com a ordem constitucional, o instituto não se apresenta restrito à legalização de determinada situação fundiária em seu aspecto dominial ou em relação à segurança jurídica da posse.

Nesse sentido, a primeira tarefa que se pretende realizar se refere à abrangência do conteúdo do termo e sua justificativa, a partir da ordem jurídica brasileira. Para tanto, o primeiro capítulo desta pesquisa, Regularização fundiária urbana de interesse social, parte da abordagem acerca dos principais fundamentos constitucionais que justificam a aplicação do instituto (1.1), notadamente a função social da propriedade (1.1.1) e o direito à moradia (1.1.2), para que seja possível empreender a delimitação conceitual do termo objeto do trabalho e sua amplitude (1.2), adotando como referencial três principais leis federais que contribuem para esta tarefa: (i) a Lei federal de Parcelamento do Solo Lei $\mathrm{n}^{\circ}$ 6.766/1979, por vincular a legalidade do parcelamento ao provimento de infraestrutura e prever processos de regularização em situações específicas referentes à ocupação por população de baixa renda (1.2.1); (ii) o Estatuto da Cidade - Lei federal $n^{\circ}$

\footnotetext{
${ }^{6}$ FERNANDES, Edésio. Introdução. In: ALFONSIN, Betânia (et alli). Regularização da Terra e Moradia: o que é e como implementar. Brasília: CAIXA/PÓLIS/FASE/ACESSO, ago./out., 2002, p.12.

${ }^{7}$ Destacam-se "as imensas diferenças entre as áreas centrais e as periféricas das regiões metropolitanas; a ocupação precária do mangue em contraposição à alta qualidade dos bairros da orla nas cidades de estuário; a eterna linha divisória entre o morro e o asfalto, e em outras variantes dessa cisão, presentes em cidades de diferentes tamanhos, diferentes perfis econômicos e regiões diversas". (ROLNIK, Raquel (coord.). Estatuto da Cidade: guia para implementação pelos nos municípios e cidadãos: Lei n.10.257, de 10 de julho de 2001, que estabelece diretrizes gerais da política urbana. 2. ed. Brasília: Câmara dos Deputados, 2002, p. 23).

${ }^{8}$ Destaca-se que apesar de se tratar de uma situação característica da urbanização nas cidades brasileiras, esse fenômeno é muito mais amplo e pode também ser encontrado em outros países em desenvolvimento, especialmente na América Latina, conforme será apresentado no decorrer do trabalho.
} 
10.257/2001, por trazer elementos conceituais que vão além da legalização do exercício da posse para atingir a regularização dos aspectos urbanísticos de parcelamentos, uso e ocupação do solo e das edificações (1.2.2); e a Lei do Programa Minha Casa, Minha Vida - Lei federal $n^{0} 11.977 / 2009$, por consolidar de modo expresso um conteúdo que não restringe a regularização fundiária à legalização da posse e, ainda, cria um procedimento administrativo específico para dar cabo ao instrumento de modo a integrar ações jurídicas, urbanísticas, ambientais e sociais (1.2.3).

No segundo capítulo, Aspectos da relação entre o Estado e a regularização fundiária urbana de interesse social, após a delimitação conceitual e considerando que o instituto tem origem a partir de uma realidade fática decorrente do desenvolvimento urbano e do fenômeno da urbanização, conforme mencionado sucintamente nos parágrafos iniciais desta introdução, faz-se importante esclarecer de que forma o Estado contribuiu para a proliferação do acesso irregular ao solo urbano (2.1) e como a Constituição Federal de 1988 (2.2) organizou as atribuições dos entes federados para normatizar e executar materialmente programas de regularização fundiária de interesse social, cabendo, ainda, o exame da legislação infraconstitucional que acaba por interferir na sistemática interfederativa em alguma medida (2.2.2).

Tendo fixadas as premissas do trabalho, tanto relacionadas à abrangência do objeto como às razões de seu surgimento e à forma como o Estado está organizado para formular e realizar projetos de regularização fundiária, a dissertação passará a identificar os instrumentos jurídicos que estão compreendidos no conceito adotado e suas características principais, com o intuito de verificar de que forma os instrumentos contribuem para a concretização do objeto do estudo.

Em Instrumentos para a regularização fundiária urbana de interesse social, terceiro capítulo desta dissertação, dividindo a abordagem entre os instrumentos destinados à regularização dominial (3.1), aqueles voltados à compatibilização dos assentamentos às normas urbanísticas (3.2) e, ainda, os que apresentam ambas as características (3.3), são examinados os seguintes mecanismos: (i) no tocando à regularização dominial de áreas públicas (3.1.1), destacam-se a Concessão de Direito Real de Uso (3.1.1.1); a Concessão de Uso Especial para Fins de Moradia (3.1.1.2); o Aforamento (3.1.1.3); a Doação (3.1.1.4); e o uso de área privadas a Usucapião Especial Urbana (3.1.2); (ii) em relação aos instrumentos voltados à regularização urbanística ressaltam-se a Zona Especial de Interesse Social (3.2.1), as Operações Urbanas Consorciadas (3.2.2) e o Consórcio 
Imobiliário (3.2.3); e (iii) no que se referem aos mecanismos que apresentam características mistas receberam relevo a Demarcação Urbanística (3.3.1); o Direito de Superfície (3.3.2); o Direito de Preempção (3.3.3) e a Desapropriação (3.3.4). Por fim, diante das peculiaridades que envolvem a regularização fundiária urbana de interesse social em Áreas de Preservação Permanente, o capítulo dedica-se também à apresentação e análise de tais especificidades (3.4).

Após a apresentação e exame do extenso rol de instrumentos jurídicos capazes de darem concretude ao instituto da regularização fundiária urbana de interesse social, o trabalho passa ao enfrentamento do tema da escassez de recursos públicos para a sua implementação que, apesar de não estar adstrito ao objeto em questão, se apresenta como elemento essencial para sua utilização em sua amplitude e complexidade pela Administração Pública.

Assim, no quarto capítulo, Viabilização de investimentos em projetos de regularização fundiária urbana de interesse social, serão apresentados possíveis arranjos jurídicos específicos da política urbana (4.1) ou típicos do direito administrativo (4.2) que podem contribuir para a viabilização de investimentos a serem aplicados em projetos de regularização fundiária urbana de interesse social. São eles: (i) a Operação Urbana Consorciada (4.1.1); (ii) a Outorga Onerosa do Direito de Construir (4.1.2); (iii) algumas possíveis formas de repasse de recursos interfederativo (4.2.1); (iv) o Consórcio Público (4.2.2); (v) a Parceria Público-Privada (4.2.3); e (vi) a Concessão Urbanística (4.2.4).

Todos os aspectos tratados, desde a delimitação do conteúdo do instituto até as formas de viabilização de investimentos a serem aplicados em projetos de regularização fundiária urbana de interesse social, contribuirão para que seja possível empreender uma abordagem crítica acerca da regularização fundiária no Capítulo V, Análise crítica da regularização fundiária urbana de interesse social, por meio da identificação de problemáticas internas (5.1) e externas (5.2) associadas à realização de projetos com esse escopo, sendo necessário o desenvolvimento de medidas específicas para que o instituto tenha efetividade.

Considerando o diagnóstico realizado a partir do histórico e do reconhecimento dessa alternativa de atuação da Administração Pública pelo ordenamento jurídico, constata-se a necessidade de analisar o instituto quanto à utilidade de sua implementação, na medida em que é composto por um extenso rol de instrumentos aplicáveis as mais variadas formas e irregularidades da ocupação do espaço urbano. Sua efetividade está 
condicionada principalmente à capacidade da Administração Pública combinar projetos de regularização fundiária, essencialmente curativos, como políticas que previnam o acesso ilegal ao solo urbano e, ainda, à procedimentalização das tomadas de decisão em tais processos, com a finalidade de garantir uma ação planejada e que considere a gama de interesses nele envolvidos. 


\section{CAPÍTULO I \\ REGULARIZAÇÃO FUNDIÁRIA URBANA DE INTERESSE SOCIAL}

Diante da especificidade do tema a ser desenvolvido nesta dissertação, faz-se importante apresentar o conceito daquilo que se denomina, já no título do trabalho, como "regularização fundiária urbana de interesse social".

Essa definição relaciona-se com duas bases fundamentais para a pesquisa: (i) a confirmação da inexistência de um conceito estanque acerca do tema, o que significa afirmar que vem sofrendo alterações no decorrer do tempo; e (ii) o fato de tais alterações representarem a tentativa de aprimoramento do instituto em decorrência de aplicações empíricas que envolveram a sua utilização pelo Poder Público (União, Estados, Distrito Federal e Municípios).

A análise dos elementos englobados no conceito de "regularização fundiária urbana de interesse social" e sua evolução no ordenamento jurídico são fundamentais para traçar os caminhos desta investigação e identificar a abrangência do conteúdo, de modo a tornar possível sua relação com os mecanismos considerados aptos a serem instrumentalizados pela Administração Pública na tarefa de ordenar o pleno desenvolvimento das funções sociais da cidade, conforme preconiza o art. 182 da Constituição Federal.

Para tanto, este capítulo analisará o quadro normativo federal que, além de dar fundamento à existência e à utilização do instituto, contribui para a acepção da expressão "regularização fundiária urbana de interesse social" aqui adotada, bem como para sua consolidação enquanto alternativa para reduzir o passivo habitacional.

O conjunto normativo aplicável ao que se pretende pode ser dividido em três grandes grupos de temas que se relacionam intrinsecamente com a regularização fundiária urbana de interesse social.

O primeiro grupo é representado pelo conjunto de fundamentos que justificam a utilização do instituto, compreendido essencialmente pelo direito à moradia, incorporado no rol dos direitos sociais previstos no art. $6^{\circ}$ pela Emenda Constitucional $n^{\circ} 26 / 2000$, e pela função social da propriedade urbana, pública ou privada, que, por meio do art. 182 da 
Constituição Federal, recebeu parâmetros mais definidos acerca de seu teor, conforme restará demonstrado.

Compreendidos no segundo grupo, encontram-se os dispositivos que colaboram para a assimilação da abrangência dada à expressão "regularização fundiária urbana de interesse social" e sua íntima relação com a urbanização e o domínio do espaço urbano.

Nesse bloco, destacam-se os seguintes marcos normativos a serem tratados em detalhe adiante: (i) Lei federal de Parcelamento do Solo - Lei $n^{\circ}$ 6.766/1979, que além de tratar do espaço urbano enquanto algo inserido em um contexto social que demanda serviços e equipamentos públicos, traz dispositivos voltados à facilitação da aprovação de parcelamentos populares ou habitações de interesse social, bem como à regularização de loteamentos e desmembramentos não autorizados ou executados em desacordo com o autorizado; (ii) Estatuto da Cidade - Lei federal $n^{\circ} 10.257 / 2001$, que fornece alguns parâmetros para a compreensão da abrangência da expressão "regularização fundiária urbana de interesse social", notadamente no que se refere à legalização do aspecto dominial em conjunto com a realização de melhorias urbanísticas, aos destinatários e às espécies de irregularidade abrangidas no conceito; e (iii) Lei do Programa Minha Casa, Minha Vida Lei federal $\mathrm{n}^{\circ} 11.977 / 2009$, que incluiu um capítulo voltado ao tratamento específico da regularização fundiária urbana de interesse social, contribuindo para a consolidação dos aspectos compreendidos no seu conceito, especificamente por meio da inclusão das medidas jurídicas, urbanísticas e ambientais no conteúdo da regularização fundiária.

Por fim, o terceiro grupo envolve a plêiade de instrumentos jurídicos utilizados para a concretização daquilo que se pretende atingir com a regularização fundiária urbana de interesse social, encontrados essencialmente na Constituição Federal, no Estatuto da Cidade, no Programa Minha Casa, Minha Vida, na Lei das Licitações e Contratos Administrativos e na Lei que regula a regularização fundiária em terras da União na Amazônia Legal.

Como se propõe, todavia, neste capítulo, buscar o conceito de regularização fundiária urbana de interesse social, fez-se importante apresentar tão somente o conjunto dos fundamentos e a disciplina normativa que delimita a abrangência do termo. Sendo assim, em função da importância evidente dos mecanismos para este trabalho, compreendidos no chamado terceiro grupo, seu tratamento específico será realizado no Capítulo III. 


\subsection{Fundamentos}

Para compreender o conceito de "regularização fundiária urbana de interesse social", é necessário reconhecer a íntima relação do instituto com direitos e garantias fundamentais constitucionalmente assegurados. Em verdade, tais direitos e garantias não apenas se relacionam com o tema da dissertação, mas podem ser identificados como fundamento para a aplicação do instituto.

A regularização fundiária tem como finalidade, conforme o próprio termo indica, tornar regular um situação fundiária que se apresenta juridicamente em desconformidade com o ordenamento jurídico. Isso significa trazer para a legalidade situações que, apesar de ilegais na sua origem, merecem ser harmonizadas com a norma jurídica, pelas mais variadas razões. Os demais adjetivos, "urbana" e "interesse social", apenas qualificam mais o tipo de regularização fundiária objeto do trabalho.

Fixada essa premissa, útil ao que se pretende neste tópico, apesar de superficial para o trabalho, duas interfaces com garantias constitucionais são facilmente identificadas.

Uma primeira relaciona-se diretamente com o direito de propriedade, bem como seu desdobramento referente à função social, previstos no art. $5^{\circ}$, incisos XXII e XXIII da Constituição Federal. Por um lado, a constatação de que a situação fundiária é ilegal remete automaticamente ao fato de que o eventual beneficiário da regularização fundiária não é o proprietário do bem e não detém título juridicamente aceito para o exercício da posse naquele espaço urbano. Por outro, é justamente a função social a que deve servir a propriedade que pode servir de fundamento para a regularização fundiária de interesse social, na medida em que sua implementação indica como consequência direta a destinação da propriedade para população de baixa renda, tornando evidente o conteúdo social a que o bem servirá.

A segunda interface encontra afinidade com o direito à moradia, previsto no art. $6^{\circ}$, caput, da Constituição Federal, que representa, de modo simplificado, a necessidade de se garantir ao ser humano o direito de utilizar algum espaço na cidade para sua habitação. Por razões históricas e estruturais identificadas no Capítulo II, tal utilização nem sempre é compatível com a legislação a priori, o que também não representa a ausência de direito à moradia. É justamente da necessidade de harmonizar esse impasse que surge a regularização fundiária urbana de interesse social como alternativa. 
Com a identificação de tais conexões, não se pretende afirmar que essas são as únicas possíveis de serem estabelecidas entre regularização fundiária urbana de interesse social e a Constituição Federal, mas são, sem dívida, as essenciais, sendo as demais apenas desdobramentos que não deixarão de ser identificados a seguir.

\subsubsection{Regularização fundiária e função social da propriedade urbana}

A relação que se estabelece entre regularização fundiária e propriedade, além de ser um tema central, confere alguns contornos importantes para a aplicação do instituto.

De início, é possível identificar certos limites aos processos de regularização fundiária de interesse social decorrentes, justamente, do direito à propriedade de quem detém o domínio de área ocupada irregularmente, por exemplo, quando há população de baixa renda ocupando área privada a menos de 5 (cinco) anos e, portanto, sem o cumprimento do lapso temporal necessário para a prescrição aquisitiva da propriedade. Nesse caso, ainda que não haja oposição do proprietário, a população não preenche os requisitos necessários para o pleito da usucapião especial urbana, prevista no art. 183 da Constituição Federal e no art. $9^{\circ}$ do Estatuto da Cidade. ${ }^{9}$

Muitas vezes, porém, é o próprio direito à propriedade que dá fundamento à regularização fundiária de interesse social, tendo em vista que a regularização pode ser um mecanismo capaz de conferir função social à determinada propriedade que a esteja descumprindo. Assim, a função social pode se apresentar como justificativa prévia à aplicação da regularização fundiária em diversas situações concretas. Nessa esteira, o próprio Estatuto da Cidade identifica a regularização fundiária como diretriz para o pleno desenvolvimento das funções sociais da cidade e da propriedade urbana, em seu art. $2^{\circ}$, inciso XIV.

A inclusão da função social no conceito de propriedade não é recente no país, tendo sua primeira previsão no art. 157, inciso III Constituição Federal de $1967 .{ }^{10} \mathrm{O}$

\footnotetext{
9 Apenas para esclarecer, na situação ilustrada, é evidente que haveria a possibilidade do Poder Público dar início a processo de regularização fundiária, mas restaria a utilização da desapropriação, já também é requisito para a demarcação urbanística o lapso de 5 (cindo) anos. No entanto, a desapropriação importaria no pagamento de indenização, que se apresenta como condicionamento que decorrem justamente do direito à propriedade do detentor do imóvel ocupado.

10 Antes de 1967, havia apenas um indicativo acerca da necessidade de encarar a propriedade como algo inserido no contexto social. Nesse sentido, a Constituição de 1946 estabelecia o uso da propriedade
} 
reconhecimento de que a propriedade, seja ela urbana ou rural, privada ou pública ${ }^{11}$, está inserida em um contexto social e, portanto, o direito de exercê-la deve ser desempenhado de modo condizente com a sua função social, acaba por transformar o conteúdo desse direito, que deixa de ser estruturado apenas na esfera individualista do proprietário.

Internaliza-se a função social como elemento no próprio conteúdo daquilo que se compreende por direito à propriedade. Segundo José Afonso da Silva, citando Fiorella D’Angelo:

[...] assim é que a função social mesma acaba por posicionar-se como elemento qualificante da situação jurídica considerada, manifestando-se, conforme as hipóteses, seja como ausência de atribuição de determinadas faculdades, seja como condição de exercício de faculdades atribuídas, seja como obrigação de exercitar determinadas faculdades de acordo com modalidades preestabelecidas. ${ }^{12}$

Nota-se que o condicionamento ${ }^{13}$ que decorre do princípio da função social da propriedade não é aqui encarado exclusivamente como "gerador de imposições negativas ao comportamento do proprietário" ${ }^{14}$, ou seja, de comandos normativos que tenham como objetivo apenas vedar condutas que descumpram a função social da propriedade. Trata-se de abranger imposições positivas no sentido do proprietário buscar exercer seu direito de

condicionado ao bem estar social (art. 147) e a Constituição de 1934 previa a impossibilidade do direito à propriedade ser exercido contrariamente ao interesse social ou coletivo (art.113, 17).

${ }^{11}$ Cumpre mencionar que a aplicabilidade do princípio da função social nas hipóteses da propriedade ser pública não é pacífica. Entretanto, por entender que se trata de um argumento sem qualquer respaldo constitucional, valho-me das palavras do jurista Floriano de Azevedo Marques Neto que bem expõem a evidente vinculação da propriedade pública à função social: "[...] nossa posição já antes externada de que todos os bens públicos devem ser, direita ou indiretamente, servientes ao atingimento de um interesse públicos, cuidando-se, neste ponto, de uma derivação do princípio da função social da propriedade." (Bens Públicos: função social e exploração econômica. O regime jurídico das utilidades públicas. Belo Horizonte: Fórum, 2009, p. 276). No mesmo sentido, Patrícia de Menezes Cardoso: "É necessário rever o conceito de propriedade pública, entendida muitas vezes como propriedade 'da Administração Pública' em sentido estrito e antagônico à função social destes imóveis para a cidade e muitas vezes ao interesse coletivo. A mera dominialidade pública não garante o cumprimento do princípio da função social da propriedade, que depende, sim, da efetiva destinação e utilização destes imóveis conforme preceitos que atendam o interesse público e efetivem uma ordem urbanística justa e sustentável” (Democratização do acesso à propriedade pública no Brasil: função social e regularização fundiária. Dissertação de mestrado. Pontifícia Universidade Católica de São Paulo, 2010, p. 18)

12 SILVA, José Afonso da. A. Direito Urbanístico Brasileiro. São Paulo: Editora Revista dos Tribunais, 1981, p. 96.

${ }^{13}$ Para José Afonso da Silva, a alteração no âmbito do conteúdo da propriedade não equivale à mera imposição de limitação ao exercício da propriedade: "O princípio da função social da propriedade á muito mais do que isso. [...] Constitui o fundamento do regime jurídico da propriedade, não de limitações, obrigações e ônus que podem apoiar-se em outros títulos de intervenção, como ordem pública ou atividade de polícia.” (SILVA, op. cit. 1981, p. 95). Não cabe ao escopo do presente tópico aprofundar o tema, tendo em vista que os efeitos práticos de se encarar a função social da propriedade como uma limitação ao direito de propriedade ou não são os mesmos. Por essa razão, adota-se a terminologia "condicionante" ou "limitantes".

${ }^{14}$ GRAU, Eros Roberto. Direito urbano. São Paulo: Revista dos Tribunais.1983, p. 65. 
maneira mais compatível com a utilidade social. ${ }^{15}$ Essa diretriz fica ainda mais evidente quando se observa no art. 182, $\S 4^{\circ}$, da Constituição Federal o estabelecimento de sanções aplicáveis às propriedades não edificadas, subutilizadas ou não utilizadas que exigem uma postura proativa do proprietário no sentido de dar função social a sua propriedade.

O conteúdo material, porém, do que se entende por função social da propriedade urbana não é facilmente extraído do ordenamento jurídico. Diferentemente da função social da propriedade rural, que encontra no art. $186^{16}$ da Constituição Federal uma delimitação material geral aplicável a todo o território nacional, a função social da propriedade urbana apresenta tão somente a diretriz no sentido de que "a propriedade urbana cumpre sua função social quando atende às exigências fundamentais de ordenação da cidade expressas no plano diretor."17

A Constituição remete claramente à norma infraconstitucional ${ }^{18}$, notadamente ao plano diretor ${ }^{19}$, a delimitação desse conteúdo, seja a propriedade pública ou privada, sem determinar o conjunto de premissas ou de elementos gerais aplicáveis a todas as

\footnotetext{
15 "A integração do princípio da função social da propriedade (ou nos conceitos de propriedade) importa em que se coloque sob contestação, por tímida e incompleta, a fórmula segundo a qual apenas não pode a propriedade ser usada de modo contrário à utilidade social. [...] verificamos que, algumas vezes, neles se inserem comandos voltados são somente à vedação do exercício da propriedade - para que não venha contrariar a utilidade social - mas à promoção do exercício da propriedade de modo mais compatível àquela utilidade." (GRAU, op. cit., p. 65).

16 "Art. 186. A função social é cumprida quando a propriedade rural atende, simultaneamente, segundo critérios e graus de exigência estabelecidos em lei, aos seguintes requisitos: I - aproveitamento racional e adequado; II - utilização adequada dos recursos naturais disponíveis e preservação do meio ambiente; III observância das disposições que regulam as relações de trabalho; IV - exploração que favoreça o bem-estar dos proprietários e dos trabalhadores." (CF)

${ }^{17}$ Art. $182, \S 2^{\circ}$ da CF.

${ }^{18}$ Ainda que a propriedade seja um direito fundamental, previsto no art. $5^{\circ}$, incisos XXII da Constituição Federal, e que, a princípio, a restrição a direitos fundamentais somente é autorizada no próprio âmbito constitucional, no caso da função social da propriedade urbana, a Constituição delegou expressamente à legislação ordinária tal incumbência. Não se trata de algo estranho à lógica Constitucional, pois, em grande medida, a Constituição fixa parâmetros mais gerais do direito deixando o detalhamento a cargo da lei ordinária, que em regra restringem, ou melhor, delimitam tais direitos fundamentais. Na hipótese de propriedade rural, essa operação fica evidenciada. Ainda que a Constituição tenha definido parâmetros gerais, é a lei que fixará, por exemplo, o conteúdo de "aproveitamento racional e adequado" (art. 186, inciso I da $\mathrm{CF}$ ).

${ }^{19}$ Conforme dispõe o art. $182, \S 1^{\circ}$ da CF, o plano diretor é obrigatório para cidades com mais de vinte mil habitantes, ou seja, não é de aprovação obrigatória em todos os Municípios brasileiros. A partir dessa constatação, duas poderiam ser as interpretações do $\S 2^{\circ}$ do mesmo dispositivo: (i) os Municípios que não são obrigados a aprovar planos diretores somente poderiam estabelecer os critérios destinados a identificar a função social de determinada propriedade se optassem por aprovar o plano diretor; (ii) ainda que a Constituição não tenha mencionado expressamente, a lei municipal de organização do espaço urbano poderia disciplinar sobre o tema. Parece-me que apenas a primeira interpretação é possível, já que adotar a segunda equivaleria a equiparar normas que claramente apresentam conteúdo diferenciado e, mais, supor que o constituinte se esqueceu de assim fazê-la. Além disso, parece evidente que a Constituição preferiu destacar o plano diretor das demais normas exaradas pelo Município acerca da política urbana.
} 
propriedades urbanas. De acordo com Fernando Dias Menezes de Almeida, no tocante à propriedade urbana privada há ao menos um aspecto material acerca da função social delimitado pela Constituição Federal: "o solo urbano não cumpre sua função social se não utilizado, subutilizado ou não edificado" ${ }^{20}$, prevista no art. 182, $4^{\circ}$ da Constituição Federal.

Observa-se que esse reconhecimento não equivale a dizer que se trata de hipótese exclusiva de não cumprimento da função social da propriedade urbana privada, mas tão somente que trata de um aspecto possível de ser identificado já na esfera constitucional.

Considerando que a Constituição estabelece, como um dos parâmetros, o descumprimento da função social da propriedade urbana quando o solo encontra-se "não edificado, subutilizado ou não utilizado", prevendo inclusive sanções ${ }^{21}$, resta saber qual o conceito desses termos até para se delimitar com clareza quais casos estão sujeitos às sanções mencionadas na Constituição.

Segundo Almeida (2004), trata-se de termos que remetem ao direito urbanístico, sendo "não edificado" o solo que não é ocupado por nenhuma edificação e "subutilizado" o solo que apresenta edificação abaixo do coeficiente de aproveitamento mínimo definido para a região onde se encontra o terreno. Para o jurista, o termo "não utilizado", por sua vez, corresponderia a determinado terreno com coeficiente de aproveitamento igual a zero, ou seja, na prática não haveria diferença entre "não edificado" e "não utilizado".

$\mathrm{O}$ argumento funda-se na intenção do autor em encontrar um critério único para o termo "utilização". Expõe o jurista que, se o termo "utilização" se referir a uso ou destinação, não haveria que se falar em "subutilizado", mas sim em mal utilizado e não utilizado. Por essa razão, a adoção do termo "utilização" para significar coeficiente de aproveitamento pareceria mais lógico. ${ }^{22}$

Entendemos, contudo, de modo diverso. Isso porque a interpretação exposta, além de tornar supérfluo o termo "não utilizado", pois não o diferencia do termo "não

\footnotetext{
${ }^{20}$ ALMEIDA, Fernando Dias Menezes de. Dos instrumentos da política urbana. Dos instrumentos em geral. Do parcelamento, edificação ou utilização compulsórios. Do IPTU progressivo no tempo. Da desapropriação com pagamento em títulos. In: ALMEIDA, Fernando Dias Menezes de; MEDAUAR, Odete (coord.). Estatuto da Cidade - Lei $n^{\circ}$ 10.527, de 10.07.2001: Comentários. São Paulo: Revista dos Tribunais Ltda., 2. ed., 2004, p. 61.

${ }^{21}$ Previstas no art. 182, §4 da CF: (i) parcelamento ou edificação compulsórios; (ii) imposto sobre a propriedade predial e territorial urbana progressivo no tempo; (iii) desapropriação com pagamento mediante títulos da dívida pública de emissão previamente aprovada pelo Senado Federal, com prazo de resgate de até dez anos, em parcelas anuais, iguais e sucessivas, assegurados o valor real da indenização e os juros legais.

${ }^{22}$ ALMEIDA, op. cit., p. 67-71.
} 
edificado", como reconhece o próprio autor, ${ }^{23}$ ainda desconsidera a possibilidade de existir imóvel "não edificado" e com coeficiente de aproveitamento igual a zero, mas com destinação compatível com sua função social. Apenas para ilustrar, tal situação pode ocorrer no caso de determinado imóvel urbano ser destinado a manter mata virgem. Nesse exemplo, o imóvel será não edificado, mas poderia ser exatamente a utilização compatível com a destinação que garante o cumprimento da função social, independentemente do coeficiente ser igual a zero.

Diante disso, parece-nos mais acertado reconhecer que o termo "utilização", quando aplicado ao solo urbano, tem mais de um sentido, pois compreende tanto o conteúdo técnico, extraído do direito urbanístico, relacionado ao coeficiente ou índice de aproveitamento e taxa de ocupação, quanto o uso ou destinação dada pelo proprietário ao solo urbano. ${ }^{24}$

Há ainda um forte argumento a ser considerado, já que a Constituição Federal estabelece três sanções a serem sucessivamente impostas, partindo do parcelamento e edificação compulsórios. Isso se deve ao marco inicial das sanções, ou seja, o parcelamento e a edificação compulsórios não se aplicam às hipóteses de uso ou destinação em desacordo com o plano diretor, mas tão somente a imóveis não edificados ou subutilizados. Essa constatação reforçaria o entendimento no sentido de que o termo "não utilizado" seria uma redundância e, portanto, equivaleria ao termo "não edificado".

Nesse sentido, o Estatuto da Cidade tratou de incluir, no rol das hipóteses de sanção prevista no art. $5^{\mathrm{o}},{ }^{25}$ a utilização compulsória. Esse alargamento, no nosso entender, é perfeitamente compatível com a Constituição Federal, pois o Estatuto da Cidade remete à possibilidade de aplicação de tais sanções à Lei Municipal específica para área definida pelo Plano Diretor, responsável pela tarefa de regular a função social da propriedade. Além disso, há outros temas que interferem de maneira muito mais agressiva no direito à propriedade, se comparada à mera aplicação de sanções, como as modalidades de desapropriação, que são inteiramente reguladas pela lei infraconstitucional.

\footnotetext{
${ }^{23}$ ALMEIDA, op. cit., p. 70.

${ }^{24}$ Destaca-se que o veto ao inciso II do art. $5^{\circ}$ do Estatuto da Cidade excluiu, acertadamente, o alargamento do conceito de subutilizado, pois tentava incluir nesse conceito os imóveis "utilizados em desacordo com a legislação urbanística ou ambiental". Entende-se por correto o veto, tendo em vista que tal conceito nos parece ser inerente ao conteúdo do termo "não utilizado".

25 “Art. $5^{\circ}$ Lei municipal específica para área incluída no plano diretor poderá determinar o parcelamento, a edificação ou a utilização compulsórios do solo urbano não edificado, subutilizado ou não utilizado, devendo fixar as condições e os prazos para implementação da referida obrigação.” (Estatuto da Cidade).
} 
Assim, em última análise, ainda que não se dê ao termo "não utilizado" o sentido aqui pretendido, como decorrência do previsto na Constituição Federal e no Estatuto da Cidade, nada há no ordenamento que impeça que outras sanções sejam disciplinadas para essa modalidade de descumprimento da função social pelo próprio plano diretor, responsável por conferir conteúdo material à função social da propriedade urbana.

No sentido de reforçar a possibilidade da lei dar concretude ao direito à propriedade e, aproveitando para trazer algumas diferenças entre a abrangência da função social da propriedade pública e privada, cumpre mencionar os ensinamentos de Floriano de Azevedo Marques Neto:

No domínio privado, esta função social será determinada pela lei e variará conforme o tipo de propriedade (urbana, rural, mobiliária, de produção etc.). No caso do domínio público, esta função social se confundirá com os usos de interesse geral que são reservados a cada espécie de bem. ${ }^{26}$

Percebe-se, no caso das propriedades públicas, além daquilo que decorre do planejamento urbano, a necessidade de se observar as espécies de bens e usos de interesse geral que são a eles reservados. Tal destinação pode ocorrer justamente por meio do Plano Diretor, instrumento que dá concretude à função social da propriedade, seja ela pública ou privada.

No caso de regularização fundiária urbana de interesse social em áreas de domínio público, há diversos elementos que se relacionam com a afetação de tais bens e ao uso em concreto, havendo situações em que o uso prevalece à afetação e vice versa. Porém, essas questões serão mais amplamente debatidas no Capítulo III em que serão abordados os instrumentos voltados à regularização fundiária de interesse social em áreas públicas.

Importa, por fim, apresentar breve abordagem acerca da existência ou não de um direito subjetivo público ao cumprimento da função social diante de uma situação fática que a descumpra. Nos dizeres de Grau:

Ser titular de um direito subjetivo é estar autorizado, pelo ordenamento jurídico, a praticar ou não praticar um ato - isto é, a transformar em ato a potência, ou seja, a aptidão para a prática de tal ato. A transformação da faculdade em ato, quando juridicamente autorizada - e aí o direito

\footnotetext{
${ }^{26}$ Bens Públicos: função social e exploração econômica. O regime jurídico das utilidades públicas. Belo Horizonte: Fórum, 2009, p. 221.
} 
subjetivo - deve ser exercida dentro dos limites da autorização. ${ }^{27}$

O direito subjetivo público representa um direito que o sujeito está autorizado a praticar considerando interesses que afetam a coletividade. Na hipótese de uma propriedade urbana não cumprir a sua função social e o Poder Público não implementar aquilo que a legislação prevê, tanto do ponto de vista das sanções, quanto do ponto de vista da promoção dessa função social na cidade, fica evidenciada a existência desse direito subjetivo público. ${ }^{28}$

Destaca-se, assim, decisão do Superior Tribunal de Justiça que reconheceu a existência de um direito subjetivo público à regularização fundiária de interesse social e um dever do Poder Público de regularizar a situação dos moradores na situação concreta. ${ }^{29}$

Cabe ao Poder Público, portanto, não apenas dar aos imóveis públicos a devida função social, mas também zelar para que ela seja devidamente observada pelos particulares que utilizam do espaço urbano para, além de habitar, desenvolver suas atividades. A omissão no tocante ao cumprimento de tais tarefas gera direito público subjetivo dos demais integrantes do espaço urbano que acabam por sofrer, direta ou indiretamente, as consequências da inação.

Desse modo, as apreciações empreendidas no presente tópico podem ser assim sintetizadas: (i) a função social da propriedade não compreende apenas imposições negativas, mas também positivas, no sentido do proprietário buscar exercer seu direito de maneira mais compatível com a utilidade social; (ii) o conteúdo material da função social

\footnotetext{
${ }^{27}$ GRAU, op. cit., p. 69.

${ }^{28}$ Neste sentido, José Afonso da Silva esclarece: "Já verificamos que normas programáticas condicionam a atividade discricionária da Administração, bem como a atividade jurisdicional. Essas atividades não podem desenvolver-se contra os fins e objetivos postos pelas normas constitucionais programáticas. Se isso ocorrer, manifesta-se um comportamento inconstitucional e o ato que dali deflui fica sujeito ao controle de constitucionalidade. [...] O princípio da função social da propriedade, por exemplo, pode ser invocado contra o abuso desse direito, em certas circunstâncias, em prol de inquilinos contra o senhorio, e especialmente impor atuações positivas ou abstenções ao proprietário, no interesse da coletividade." (Aplicabilidade das normas constitucionais. 8. ed. São Paulo: Malheiros, 2012, p. 172-174)

29 "RECURSO ESPECIAL. DIREITO URBANÍSTICO. LOTEAMENTO IRREGULAR. MUNICÍPIO. PODER-DEVER DE REGULARIZAÇÃO. 1. O art. 40 da lei 6.766/79 deve ser aplicado e interpretado à luz da Constituição Federal e da Carta Estadual. 2. A Municipalidade tem o dever e não a faculdade de regularizar o uso, no parcelamento e na ocupação do solo, para assegurar o respeito aos padrões urbanísticos e o bem-estar da população. 3. As administrações municipais possuem mecanismos de autotutela, podendo obstar a implantação imoderada de loteamentos clandestinos e irregulares, sem necessitarem recorrer a ordens judiciais para coibir os abusos decorrentes da especulação imobiliária por todo o País, encerrando uma verdadeira contraditio in terminis a Municipalidade opor-se a regularizar situações de fato já consolidadas. (...) 5. O Município tem o poder-dever de agir para que o loteamento urbano irregular passe a atender o regulamento específico para a sua constituição. 6. Se ao Município é imposta, ex lege, a obrigação de fazer, procede a pretensão deduzida na ação civil pública, cujo escopo é exatamente a imputação do facere, às expensas do violador da norma urbanístico-ambiental. 7. Recurso especial provido." (REsp 448216 / SP RECURSO ESPECIAL 2002/0084523-8 - Ministro LUIZ FUX PRIMEIRA TURMA - Data do Julgamento 14/10/2003- DJ 17.11.2003 p. 204) (grifo nosso)
} 
da propriedade urbana é delegado para esfera infraconstitucional, notadamente o Plano Diretor, mas há uma parcela desse conteúdo já definido pela Constituição Federal no art. $183, \S 4^{\circ}$ da Constituição Federal; (ii.a) os termos "não edificado", "subutilizado" e "não utilizado" são distintos e compreendem, respectivamente, o solo que não é ocupado por nenhuma edificação; o imóvel que apresenta coeficiente ou índice de aproveitamento e taxa de ocupação inferiores ao exigido no Plano Diretor; e o uso ou destinação incompatível com o Plano Diretor; (ii.b) não há inconstitucionalidade no alargamento das hipóteses em que cabem as sanções previstas no art. $183, \S 4^{\circ}$ da Constituição Federal, pelo art. $5^{\circ}$ do Estatuto da Cidade, já que a própria Constituição confere ao Plano Diretor a tarefa de regular a função social da propriedade; (iii) os bens de domínio público são condicionados pelo Plano Diretor e pelos usos de interesse geral que são a eles reservados; e (iv) há direito subjetivo público ao cumprimento da função social diante de uma situação fática que a descumpra.

\subsubsection{Regularização fundiária e direito à moradia}

A consagração do direito à moradia como direito social constitucionalmente assegurado ocorreu apenas em 2000, por meio da Emenda Constitucional n 26 (EC26). É evidente que a interpretação dos demais mandamentos constitucionais, como a dignidade da pessoa humana, prevista no art. $1^{\mathrm{o}}$, inciso III; a erradicação da pobreza e da marginalização e redução das desigualdades sociais, como objetivos fundamentais da República, previstos no art. $3^{\circ}$, inciso III; o direito à saúde, à segurança e à assistência aos desamparados, previstos no caput do art. $6^{\circ}$ antes da EC26, todos da Constituição Federal, já permitia reconhecer a moradia como um elemento essencial da vida humana em sociedade. ${ }^{30}$

Mesmo antes da EC26 e em alguns casos antes da própria Constituição Federal, o Brasil já era signatário de uma série de Tratados Internacionais ${ }^{31}$ que reconheciam a moradia como um elemento integrante dos chamados direitos humanos. Dentre o rol

\footnotetext{
${ }^{30}$ FERRAZ, Sérgio. Usucapião Especial. In: DALLARI, Adilson de Abreu; FERRAZ, Sérgio (coord.). Estatuto da Cidade: Comentários à Lei Federal no 10.257/2001. São Paulo: Malheiros, 2003, p. 144.

31 Além dos tratados, existe uma séria de declarações que, mesmo não tendo o mesmo efeito jurídico, também expõe o reconhecimento da moradia como algo essencial ao ser humano. A Declaração Universal dos Direitos Humanos de 1948 assim estabelece em seu artigo XXV: "Toda pessoa tem direito a um padrão de vida capaz de assegurar a si e a sua família saúde e bem estar, inclusive alimentação, vestuário, habitação, cuidados médicos e os serviços sociais indispensáveis [...]”. Podem ainda ser citadas as seguintes: Declaração Sobre Assentamos Humanos de Vancouver, de 1976; Declaração sobre o Desenvolvimento, de 1986; Agenda 21, de 1992; e Agenda Habitat, de 1996 (SAULE JUNIOR, Nelson. A proteção jurídica da moradia nos assentamentos irregulares. Sergio Antonio Fabris Editor: Porto Alegre, 2004, p. 119).
} 
exemplificativo, destacam-se: (i) Convenção Internacional sobre a Eliminação de Todas as Formas de Discriminação Racial, ratificada pelo Decreto $n^{\circ} 65810 / 1969^{32}$; (ii) Pacto Internacional dos Direitos Econômicos, Sociais e Culturais, aprovado em 1966, mas em vigor desde 1976, e ratificado por meio do Decreto $n^{\circ} 591 / 1992^{33}$; (iii) Convenção sobre a Eliminação de Todas as Formas de Discriminação contra a Mulher, ratificado pelo Decreto $n^{\text {o }} 4377 / 2002^{34}$; entre outros.

Diante, contudo, do entendimento do Supremo Tribunal Federal, que, de início, considerava a recepção dos tratados internacionais com status de lei ordinária federal ${ }^{35} \mathrm{e}$, posteriormente, como norma supralegal ${ }^{36}$, ou seja, em um patamar de hierarquia intermediário, entre a Constituição Federal e a lei federal ordinária ${ }^{37}$, todo esse quadro normativo de obrigações internacionalmente assumidas permanecia em patamar inferior ao constitucional, até a edição da mencionada EC26 que incorporou de maneira expressa o direito à moradia. ${ }^{38}$

Isso significou um avanço a mais do ponto de vista jurídico, mas não reduziu a dificuldade prática de dar efetividade a esse direito social. Uma das razões que pode ser destacada é o fato de tal direito apresentar um conteúdo incerto, podendo ser amplo ou

\footnotetext{
32 “Artigo V: De conformidade com as obrigações fundamentais enunciadas no artigo 2, Os Estados Partes comprometem-se a proibir e a eliminar a discriminação racial em todas suas formas e a garantir o direito de cada uma à igualdade perante a lei sem distinção de raça, de cor ou de origem nacional ou étnica, principalmente no gozo dos seguintes direitos: (...) e) direitos econômicos, sociais culturais, principalmente: (...) iii) direito à habitação."

33 “Artigo 11, item 1: Os Estados Partes do presente Pacto reconhecem o direito de toda pessoa a um nível de vida adequando para si próprio e sua família, inclusive à alimentação, vestimenta e moradia adequadas, assim como a uma melhoria continua de suas condições de vida. Os Estados Partes tomarão medidas apropriadas para assegurar a consecução desse direito, reconhecendo, nesse sentido, a importância essencial da cooperação internacional fundada no livre consentimento." (grifo nosso)

34 “Art. 14, item 2. Os Estados-Partes adotarão todas as medias apropriadas para eliminar a discriminação contra a mulher nas zonas rurais a fim de assegurar, em condições de igualdade entre homens e mulheres, que elas participem no desenvolvimento rural e dele se beneficiem, e em particular as segurar-lhes-ão o direito a: (...) h) gozar de condições de vida adequadas, particularmente nas esferas da habitação, dos serviços sanitários, da eletricidade e do abastecimento de água, do transporte e das comunicações."

${ }^{35} \mathrm{HC} 72.131 / \mathrm{RJ}, 22.11 .1995$.

${ }^{36}$ RE 466.343/SP, 13.12.2008.

${ }^{37}$ Existe uma terceira corrente que entende, com fundamento no art. $5^{\circ}, \S 2^{\circ}$ da CF, que os tratados de direitos humanos são internalizados com força de norma constitucional, não havendo, portanto, distinção hierárquica entre os direitos humanos previstos na Constituição e aqueles disciplinados por tratados internacionais. (Cf. PIOVESAN, Flávia. Temas de Direitos Humanos. São Paulo: Max Limonad, 2003).

${ }^{38}$ Percebe-se um enorme vácuo entre o processo de urbanização nas cidades brasileiras, que encontra seu marco na década de 1960, quando o país passou a ter mais pessoas morando nas cidades do que no campo, e o reconhecimento do direito à moradia pela Constituição Federal.
} 
restrito, dando margem a uma série de modulações a depender da interpretação dada ${ }^{39}$. Por exemplo, há acórdãos no Supremo Tribunal Federal que usam o mesmo direito à moradia, ora para justificar a decisão no sentido de obrigar determinado Município a retirar população que está instalada em área de risco, identificando que a situação de risco afronta o direito à moradia, ${ }^{40}$ ora para confirmar a inalienabilidade de bens de família ${ }^{41}$.

Na ausência de uma definição constitucional, legal ou infralegal acerca do conteúdo do direito em análise, propõe-se a definição adotada pelo Comitê dos Direito Econômicos, Sociais e Culturais da $\mathrm{ONU}^{42}$ que, por meio do Comentário Geral $\mathrm{n}^{\mathrm{o}} 4$, identificou sete componentes para a garantia eficaz do direito à moradia. São eles: segurança jurídica da posse, habitabilidade, disponibilidade de serviços e infraestrutura, custo acessível da moradia, acessibilidade, localização e adequação cultural. Nesse conceito, percebe-se de maneira mais evidente que o conteúdo de direito à moradia inclui o direito humano de viver com segurança, paz e dignidade.

Apenas com a definição exposta no item acima acerca da regularização fundiária já é possível verificar sua clara interface, no mínimo, com a questão da estabilidade da posse. Todavia, como será abordado ainda neste capítulo, a análise daquilo que a legislação prevê acerca do conteúdo da regularização fundiária urbana de interesse social permite observar um alargamento dessa interface entre ambos. Não poderia ser diferente, já que a regularização fundiária urbana de interesse social é um mecanismo para a concretização do direito à moradia.

\subsection{Abrangência: regularização fundiária, domínio da terra e urbanização}

Em linhas gerais, até o presente momento, é possível afirmar que a regularização fundiária apresenta interfaces com a propriedade, notadamente sua função social, tendo em vista que a regularização fundiária em grande medida busca, justamente, garantir que a função social da propriedade seja concretizada e, com o direito à moradia, na medida em que surge como mecanismo capaz de dar efetividade ao direito.

\footnotetext{
${ }^{39}$ Para se ter uma ideia da dificuldade de definição da amplitude dessa garantia, há uma organização intitulada Global Housing Policy Indicators (Disponível em: <http://globalhousingindicators.org $>$ ) que busca encontrar indicadores comuns para políticas que tenham como objetivo a garantia do direito à moradia.

${ }^{40} \mathrm{STF}$ AI $708667 \mathrm{AgR} / \mathrm{SP}$.

${ }^{41} \mathrm{STF}$ AC $2597 \mathrm{MC}-\mathrm{QO} / \mathrm{DF}$.

42 Órgão das Nações Unidas de Controle da Aplicação dos Tratados em matéria de Direitos Humanos.
} 
Fixados tais fundamentos que justificam a aplicabilidade do instituto da regularização fundiária urbana de interesse social na ordem jurídica, cumpre esclarecer a evolução desse conceito, a partir do referencial da legislação infraconstitucional, para que seja possível se chegar ao conceito adotado nesta pesquisa.

\subsubsection{Lei federal $n^{0}$ 6.766/1979 - Parcelamento do Solo Urbano}

A Lei federal $n^{\circ} 6.766$ de 19 de dezembro de 1979 representa um importante marco do ponto de vista do Direito Urbanístico brasileiro, já que alterou a visão dominante no período em que foi aprovada. ${ }^{43}$ Encarava-se, até então, o espaço urbano como "mero aglomerado de lotes privados e alguns espaços públicos, cujas restrições ao pleno exercício do direito de propriedade advinham de limitações administrativas principalmente em função das relações de vizinhança". ${ }^{44}$ Com a aprovação da Lei de Parcelamento do Solo, reconheceu-se formalmente a necessidade de envolvimento do Poder Público na definição das regras mínimas que serviriam de base para o estabelecimento das condições aceitáveis para o parcelamento do solo e sua posterior utilização, considerando o espaço urbano como um todo, e tratando o espaço urbano enquanto algo inserido em um contexto social que demandava serviços e equipamentos públicos.

A Lei sofreu alterações sucessivas ${ }^{45}$ para sua adaptação à realidade e complexidade atual, merecendo destaque a Lei federal $n^{\circ}$ 9.785/1999 que promoveu alterações no sentido de facilitar a aprovação de parcelamentos populares ou habitações de interesse social, bem como de regularizar loteamentos e desmembramentos não autorizados ou executados em desacordo com o ato de licença.

Como elementos centrais da Lei em destaque, pode-se identificar a delimitação de parâmetros legais para o loteamento e o desmembramento, institutos por meio dos quais se realiza o parcelamento do solo urbano. Há previsão acerca da necessidade da legislação

\footnotetext{
43 O "Primeiro Seminário de Direito Urbano" foi promovido em 1973 tendo sido seguido por estudos inovadores de Lima (Lima, 1973) e Moreira (Moreira Neto, 1975), lidando especificamente com Direto Urbanístico. A aprovação da progressista Lei federal $n^{\circ} 6.766$, em 1973, que regula o parcelamento do solo urbano, foi um marco fundamental, tendo consolidado uma mudança de enfoque em relação aos antigos preceitos do Código Civil. (FERNANDES, Edésio. Direito Urbanístico: entre a "cidade legal"e a "cidade ilegal". In: FERNANDES, Edésio (org.). Direito Urbanístico. Belo Horizonte: Del Rey, 1988, p.7)

${ }^{44}$ FERNANDES, op.cit., 1988, p. 6.

${ }^{45}$ Tendo a última delas sido aprovada em 2012 pela Lei $\mathrm{n}^{\circ} 12.608$.
} 
Municipal dividir o município em zonas destinadas à identificação dos usos permitidos e de índices urbanísticos de parcelamento e ocupação do solo diferenciado em cada zona, incluindo as áreas mínimas e máximas de lotes e seus coeficientes máximos de aproveitamento ${ }^{46}$.

A Lei estabelece como requisito para o parcelamento a obrigatoriedade do terreno ser servido de infraestrutura básica ${ }^{47}$, constituída pelos equipamentos urbanos de escoamento das águas pluviais, iluminação pública, esgotamento sanitário, abastecimento de água potável, energia elétrica pública e domiciliar e vias de circulação. $^{48}$ Os loteamentos devem, ainda, ter áreas destinadas a sistemas de circulação, a implantação de equipamento urbano $^{49}$ e comunitário $^{50}$, bem como a espaços livres de uso público, proporcionais à densidade de ocupação, podendo o Poder Público estabelecer faixas non aedificandi para ambas as hipóteses. ${ }^{51}$

Percebe-se que os aspectos que envolvem a estrutura urbana dos loteamentos passam a ser inseridos como requisito para o parcelamento, ou seja, torna-se um requisito de legalidade do parcelamento para a ordem jurídica.

A relação que se estabelece entre os aspectos urbanísticos e aquilo que a legislação reconhece como legal do ponto de vista da ocupação do espaço urbano é um dos elementos centrais da conceituação do tema em análise nesta dissertação. Isso porque, como será demonstrado adiante, a urbanização é elemento que compõe o conceito de regularização fundiária urbana de interesse social.

Embora a lei federal em análise não mencione especificamente o termo regularização fundiária urbana de interesse social, não deixa de tratar aspectos que envolvem, ainda que indiretamente, a regularização fundiária. Assim o faz, criando exceções às regras que a própria lei prescreve, nas hipóteses em que o loteamento ou desmembramento tenha como finalidade a realização de programas habitacionais declarados como de interesse social ou parcelamentos populares.

Cumpre salientar que mesmo não sendo o enfoque dessa lei o tema da regularização

\footnotetext{
${ }^{46}$ Art. $4^{\mathrm{o}}, \S 1^{\mathrm{o}}$ da Lei $\mathrm{n}^{\mathrm{o}} 6.766 / 1979$.

${ }^{47}$ Art. $2^{\circ}, \S 4^{\circ}$ da Lei $n^{\circ} 6.766 / 1979$.

${ }^{48}$ Art. $2^{\circ}, \S 5^{\circ}$ e $\S 6^{\circ}$ da Lei ${ }^{\circ} 6.766 / 1979$.

49 “Art. 5\%, Parágrafo único: Consideram-se urbanos os equipamentos públicos de abastecimento de água, serviços de esgoto, energia elétrica, coletas de águas pluviais, rede telefônica e gás canalizado." (Lei $\mathrm{n}^{\circ}$ $6.766 / 1979)$

50 “Art. $4^{\text {o }}, \S 2^{\text {o: }}$ : Consideram-se comunitários os equipamentos públicos de educação, cultura, saúde, lazer e similares." (Lei n ${ }^{\circ} 6.766 / 1979$ )

${ }^{51}$ Art. $5^{\circ}$ e art. $4^{\circ}, \S 3^{\circ}$ da Lei $n^{\circ} 6.766 / 1979$.
} 
fundiária e, também por isso, a questão é abordada de modo tímido, trata-se da primeira norma federal a reconhecer diferentes padrões de parcelamento, uso e ocupação do solo quando diante de projetos voltados para população de baixa renda. ${ }^{52}$

São exemplos os seguintes dispositivos: art. $4^{\circ}$, II, que estabelece exceção à regra da área mínima de $125 \mathrm{~m}^{2}$ (cento e vinte e cinco metros quadrados) e frente mínima de 5 (cinco) metros para lotes, nas hipóteses em que o loteamento se destinar a edificação de conjuntos habitacionais de interesse social; art. $18^{\circ}, \S 4^{\circ}$ e $\S 5^{\circ}$, que flexibiliza a exigência de título de propriedade para o registro do loteamento ou do desmembramento nos casos de parcelamento popular, prevendo como alternativa a disponibilização de cópias autênticas da decisão que tenha concedido a imissão provisória na posse, do decreto de desapropriação, do comprovante de sua publicação na imprensa oficial e, quando formulado por entidades delegadas, da lei de criação e de seus atos constitutivos.

A partir dos dispositivos mencionados, dois aspectos podem ser extraídos. O primeiro é o reconhecimento de que o parâmetro mínimo exigido para o lote poderia dificultar a realização de empreendimentos de habitação de interesse social e o segundo refere-se à flexibilização de regras envolvendo o registro dos lotes. Esse dois aspectos, embora aqui indicados de maneira superficial, serão mais trabalhados no decorrer do trabalho, porque são temas intrinsecamente relacionados com algumas das irregularidades fundiárias que acabam por dar ensejo a medidas de regularização.

Considerando, no entanto, a existência de previsões que se relacionam com a regularização fundiária de interesse social, dando destaque para questões que permanecem relevantes para o instituto, a Lei de Parcelamento do Solo tem uma aplicabilidade e abrangência que vão muito além do tema da regularização, razão pela qual passamos a analisar os demais quadros normativos federais.

\subsubsection{Lei federal $n^{0} 10.257 / 2001$ - Estatuto da Cidade}

Cumpre salientar que o escopo do presente tópico está restrito aos dispositivos do Estatuto da Cidade que podem contribuir para a fixação do conceito da expressão

\footnotetext{
52 Nesse sentido, "a admissão de tamanhos de lotes diferenciados para loteamentos de interesse social, mesmo não tendo alterado o regime jurídico para a produção de moradias de interesse social, representou um avanço, na medida que possibilitou a regularização, pelo Município, de casas populares construídas em parcelamentos informais”. (SAULE JÚNIOR, op. cit. 2004, p. 352).
} 
"regularização fundiária urbana de interesse social". Afirma-se, com isso, que, apesar do Estatuto da Cidade prever uma série de dispositivos que regulam instrumentos aptos a serem utilizados em processos de regularização fundiária urbana de interesse social, a análise dos instrumentos terá lugar no Capítulo III da dissertação.

Diferentemente da análise da Lei de Parcelamento do Solo Urbano, é possível, a partir da análise das disposições do Estatuto da Cidade, identificar um conteúdo mais delimitado do termo "regularização fundiária", ainda que a expressão não seja apresentada de modo simples e direto.

No art. $2^{\circ}$, inciso XIV, o Estatuto da Cidade considera a regularização fundiária e a urbanização de áreas ocupadas por população de baixa renda como diretriz para que a política urbana atinja seu objetivo de ordenar o pleno desenvolvimento das funções sociais da cidade e da propriedade urbana, nos seguintes termos:

Art. $2^{\circ}$ A política urbana tem por objetivo ordenar o pleno desenvolvimento das funções sociais da cidade e da propriedade urbana, mediante as seguintes diretrizes gerais:

$[\ldots]$

XIV - regularização fundiária e urbanização de áreas ocupadas por população de baixa renda mediante o estabelecimento de normas especiais de urbanização, uso e ocupação do solo e edificação, consideradas a situação socioeconômica da população e as normas ambientais;

Nesse primeiro dispositivo, é possível identificar as seguintes características em relação à regularização fundiária: (i) a regularização fundiária e a urbanização são ações distintas, mas interligadas; (ii) destina-se à população de baixa renda; (iii) é um mecanismo que serve como fundamento para o estabelecimento de exceções ou diferenças normativas relacionadas à urbanização, uso e ocupação; (iv) compreende aspectos relacionados ao uso e ocupação do solo e das edificações; e (v) deve ser compatível com normas ambientais.

No capítulo II do Estatuto da Cidade, destinado a identificar instrumentos da política urbana, o art. $4^{\circ}$, inciso $\mathrm{V}$, alínea "q", ${ }^{53}$ prevê a regularização fundiária no rol dos institutos jurídicos e políticos ${ }^{54}$, sem estabelecer qualquer delimitação, ou seja, é possível

\footnotetext{
53 “Art. $4^{\text {o }}$ Para os fins desta Lei, serão utilizados, entre outros instrumentos: (...) V - institutos jurídicos e políticos: (...) q) regularização fundiária.” (Estatuto da Cidade)

${ }^{54}$ Acerca dessa classificação, Adilson Abreu Dallari esclarece que a regularização fundiária mencionada no dispositivo não corresponde a específico instituto jurídico, mas, sim, identifica a prática de enfrentar situações desconformes com a legislação urbanística, registral ou civil. (Instrumentos da Política Urbana. In: DALLARI, Adilson Abreu; FERRAZ, Sérgio. Estatuto da Cidade, Comentários à Lei $n^{\circ}$ 10.527/2001. São Paulo: Malheiros, 2002, p. 82) Para Fernando Dias Menezes de Almeida, a regularização fundiária configura uma medida de caráter político que pode, de modo direto ou indireto, afetar o regime das limitações
} 
entender que o conteúdo do termo "regularização fundiária" pode ir além do exposto no mencionado art. $2^{\circ}$.

Outros elementos são inseridos no conceito, na medida em que logo no art. $4^{\circ}$, inciso $\mathrm{V}$, alínea "t" ${ }^{55}$ e depois nos artigos 26 , inciso $\mathrm{I}^{56}$ e 35 , inciso III, ${ }^{57}$ o termo "regularização fundiária" passa a fundamentar a utilização de outros instrumentos indicados pelo Estatuto da Cidade, como a (i) demarcação urbanística; o (ii) direito de preempção; e (iii) a transferência do direito de construir.

Além disso, ora o termo é utilizado de modo a identificar os destinatários, como ocorre nos artigos $2^{\circ}$, inciso XIV, e 35, inciso III, que mencionam "população de baixa renda", ora a legislação aparenta permitir que a regularização fundiária tenha qualquer outro destinatário. Entretanto, apesar do art. 4º, inciso V, alínea "t", e do art. 26, inciso I, não mencionarem expressamente a população de baixa renda como destinatária da regularização, o Estatuto da Cidade não fornece subsídios para que seja empreendida tendo como finalidade outros destinatários. ${ }^{58}$

No caso do art. 26, inciso I do Estatuto da Cidade, que regula o direito de preempção, referida afirmação evidencia-se. Isso porque, apesar do dispositivo não mencionar a necessidade de haver interesse social na regularização fundiária utilizada como justificativa para o exercício do direito de preempção, não nos parece possível que

(ALMEIDA, op. cit. 2004, p. 53). Indo além, Betânia de Moraes Alfonsin identifica a regularização fundiária como uma política pública que tem dimensões jurídicas, urbanísticas, ambientais e sociais (O significado do Estatuto da Cidade para os processos de regularização fundiária no Brasil. In: Regularização Fundiária Plena referencias conceituais. Brasília: Ministério das Cidades, 2007, p. 79). Entendemos que a regularização fundiária, ainda que tenha um caráter jurídico inerente a sua implementação (seja no tocante ao aspecto dominial do exercício da posse ou em relação à flexibilização de normas de parcelamento, uso e ocupação do solo), apresenta também um conteúdo político que a aproxima do conceito de política pública, já que, utilizando-se da definição proposta por Maria Paula Dallari Bucci, a regularização fundiária urbana de interesse social se caracteriza como um programa de ação governamental resultante de um processo juridicamente regulado no sentido de coordenar a atuação do Estado e as atividades privadas para a realização de seu objeto que se apresenta como socialmente relevante e politicamente determinado. (O conceito de política pública em direito. In: BUCCI, Maria Paula Dallari (org.) Políticas Públicas: reflexões sobre o conceito jurídico. São Paulo: Saraiva, 2006, p. 39).

55 “Art. $4^{\circ}$ Para os fins desta Lei, serão utilizados, entre outros instrumentos: [...] V - institutos jurídicos e políticos: [...] t) demarcação urbanística para fins de regularização fundiária.” (Estatuto da Cidade)

56 “Art. 26. O direito de preempção será exercido sempre que o Poder Público necessitar de áreas para: I regularização fundiária." (Estatuto da Cidade)

57 “Art. 35. Lei municipal, baseada no plano diretor, poderá autorizar o proprietário de imóvel urbano, privado ou público, a exercer em outro local, ou alienar, mediante escritura pública, o direito de construir previsto no plano diretor ou em legislação urbanística dele decorrente, quando o referido imóvel for considerado necessário para fins de: [...] III - servir a programas de regularização fundiária, urbanização de áreas ocupadas por população de baixa renda e habitação de interesse social.” (Estatuto da Cidade)

${ }^{58}$ Diferentemente da Lei do Programa Minha Casa, Minha Vida que diferencia a regularização fundiária de interesse social da regularização fundiária de interesse específico. (art. 61 da Lei n 11.977/2009). 
esse direito seja exercido em casos de regularização fundiária que não tenha interesse social. O entendimento em sentido contrário autorizaria o exercício do direito de preferência do Poder Público na compra de determinado imóvel em benefício de um destinatário que tem condições de disputar área urbana no mercado formal e, portanto, sem a atuação do Poder Público. Por tal razão, a utilização do instituto justifica-se tão somente diante da constatação do interesse social.

Sendo assim, apesar do Estatuto da Cidade deixar de qualificar expressamente o "interesse social” da regularização fundiária urbana em alguns de seus dispositivos, isso parece ser um condicionante que decorre necessariamente de sua interpretação sistemática.

Após o levantamento dos dispositivos, depreende-se que o Estatuto da Cidade buscou dar elementos para a conceituação da regularização fundiária urbana de interesse social sendo possível, a partir dos parâmetros destacados, chegar-se a uma definição.

Entender-se-ia por regularização fundiária urbana o instituto jurídico e político (i) voltado à regularização dos aspectos jurídicos de áreas ocupadas irregularmente, incluindo a possibilidade de fixação de exceções ou diferenças normativas no tocante à urbanização, uso e ocupação ${ }^{59}$, (ii) respeitadas as normas ambientais, (iii) sem determinação a priori de destinatários, mas tendo a população de baixa renda como destinatária na hipótese de haver interesse social, (iv) podendo abranger irregularidades decorrentes do uso e ocupação do solo e das edificações.

No que toca ao caráter jurídico da regularização fundiária, cabe um breve esclarecimento, já que a lei em análise não apresenta uma delimitação acerca da abrangência desse conteúdo jurídico.

Existe uma parcela jurídica da regularização fundiária que prescinde de qualquer prescrição mais objetiva da lei, pois decorre da própria expressão, como mencionado anteriormente. Trata-se da parcela relacionada à legalização do domínio, por meio da titulação da propriedade ou da posse, aos ocupantes de áreas ilegais. Regulariza-se a situação fundiária da área ocupada, tendo em vista que quem faz uso do domínio útil em tais localidades não apresenta título formalmente reconhecido pelo ordenamento jurídico

\footnotetext{
${ }^{59}$ A flexibilização das normas relacionadas à urbanização, ao uso e à ocupação do solo nada mais representa do que a possibilidade de utilizar os institutos jurídicos-urbanísticos voltados à ordenação das cidades de modo diverso, para permitir a regularização fundiária de interesse social. Conforme ensina José Afonso da Silva, são institutos jurídicos-urbanísticos "o arruamento, o loteamento, o desmembramento, o solo criado, ao índices urbanísticos (taxa de ocupação do solo, coeficiente de aproveitamento do solo, recuos, gabaritos)" (SILVA, op. cit. 1981, p. 30). Nota-se que a flexibilização pode abranger tanto normas referentes à infraestrutura urbana, quanto às normas específicas para cada lote.
} 
que o autorize a exercê-lo. Importa para essa parcela o aspecto da ilegalidade no exercício do domínio útil do bem.

Reconhecer a existência dessa parcela, porém, não significa afirmar que o conceito de regularização fundiária de interesse social se restrinja ao aspecto estritamente dominial. Tal redução poderia gerar efeitos que vão de encontro ao pretendido por meio da utilização do instituto, que serão abordadas no Capítulo $\mathrm{V}$ da dissertação.

A parcela dominial da expressão "regularização fundiária", contudo, está tão internalizada no próprio termo que não houve, na legislação, qualquer delimitação nesse sentido, partindo-se do pressuposto que esse conteúdo é decorrência lógica da expressão.

Ainda que de modo pouco profundo, entretanto, o Estatuto da Cidade vai além desse conteúdo jurídico meramente relacionado à titulação ou à regularização da posse e prevê uma íntima relação entre regularização fundiária e urbanização. Assim o faz, estabelecendo a possibilidade de flexibilização de normas referentes à urbanização, uso e ocupação do solo e das edificações para a implementação da regularização fundiária.

Tal lei amplia, portanto, o conteúdo jurídico da regularização fundiária englobando: (i) ações jurídicas destinadas à adequação das ocupações irregulares em relação à titulação dos ocupantes, bem como (ii) a flexibilização de seus aspectos urbanísticos, de uso e ocupação do solo e das edificações, compreendidas as normas relacionadas às infraestruturas urbanas, como saneamento, esgoto, energia elétrica; ao tipo de uso permitido em determinada região, bem como às áreas mínimas e máximas de lotes, à taxa de ocupação e aos coeficientes ou índices máximos de aproveitamento dos lotes.

Tal ampliação denota claramente o reconhecimento de que a regularização fundiária tem associação direta à urbanização, apesar de serem ações distintas. Por essa razão, o Estatuto da Cidade inclui no conteúdo jurídico de regularização fundiária a possibilidade de estabelecimento de normas diferenciadas relacionadas à urbanização, ao uso e à ocupação do solo e das edificações.

Desse modo, ainda que seja possível extrair do Estatuto da Cidade uma concepção ampliada do termo, procurou-se demonstrar que disciplina normativa federal acerca da regularização fundiária de interesse social, quando havia tão somente o referencial da Lei de Parcelamento do Solo e o Estatuto da Cidade, apresenta uma série de lacunas, na medida em que o ordenamento jurídico não havia consolidado de maneira mais profunda todos os aspectos abrangidos pelo conceito em questão. 


\subsubsection{Lei federal no 11.977/2009 - Programa Minha Casa, Minha Vida}

O marco jurídico federal acerca da regularização fundiária urbana de interesse social ocorreu com a Medida Provisória n $n^{\circ}$ 459/09, convertida na Lei federal $n^{\circ}$ 11.977/09, instituindo o Programa Minha Casa Minha Vida do Governo Federal. Com a inauguração de uma nova política destinada à produção de moradia popular em grande escala no país ${ }^{60}$, aliada ao fato do Projeto de Lei de revisão da Lei federal nº 6.766/1979, que tinha um capítulo destinado à regularização fundiária, não avançar na Câmara dos Deputados, a pressão política para um marco normativo referente à regularização fundiária fez-se ainda mais presente. ${ }^{61}$ Foi, então, positivado na Lei federal $\mathrm{n}^{\circ} 11.977 / 09$ o conteúdo do termo regularização fundiária, nos seguintes termos:

Art. 46. A regularização fundiária consiste no conjunto de medidas jurídicas, urbanísticas, ambientais e sociais que visam à regularização de assentamentos irregulares e à titulação de seus ocupantes, de modo a garantir o direito social à moradia, o pleno desenvolvimento das funções sociais da propriedade urbana e o direito ao meio ambiente ecologicamente equilibrado. (Grifo nosso)

Consagrou-se uma concepção ainda mais abrangente se considerado o previsto no Estatuto da Cidade, já que se insere no conceito de regularização fundiária não apenas o conjunto de medidas jurídicas já abarcadas no conceito anteriormente mencionado, mas também ambientais e sociais destinadas à regularização de assentamentos irregulares. Há, ainda, de maneira mais expressa, a inclusão de medidas anteriormente consideradas "urbanísticas", como, por exemplo, a instituição de exceções no que se refere ao zoneamento ou, ainda, a criação de diferentes padrões de construções, no próprio conteúdo

\footnotetext{
60 "Na formulação do Programa Minha Casa, Minha Vida, possivelmente devido às críticas de que as propostas iniciais do governo somente consideravam novas construções e não tocavam na questão da regularização dos assentamentos existentes, os formuladores da MP n 459/09 buscaram no PL no 3.057 a seção da regularização fundiária de interesse social e a inseriram, com algumas modificações positivas, na nova Medida Provisória que foi convertida na Lei Federal n 11.977/2009”. (FERNANDES, Edésio. Desafios da regularização fundiária de assentamentos informais consolidados em áreas urbanas. In Biblioteca Digital Fórum de Direito Urbano e Ambiental - FDUA, Belo Horizonte, ano 9, n. 49, jan/fev. 2010. Disponível em: $<\mathrm{http}$ //www.editoraforum.com.br/bid/bidConteudoShow.aspx?idConteudo=65211>. Acesso em: 21 fev. 2011).

${ }^{61}$ Segundo Renato Balbim, "verificou-se a oportunidade para a realização deste desmembramento de temas, deixando o parcelamento e seus demais aspectos no âmbito do Projeto de Lei $n^{\circ}$ 3.057/2000, de revisão da Lei $n^{\circ}$ 6.766/1979, em trâmite, e trazendo para dentro da lei de criação do programa habitacional os elementos necessários para a efetivação da regularização fundiária urbana, como forma e estratégia de se dar maior acesso à terra e, consequentemente, maior efetividade ao programa." (Avanços recentes no quadro normativo federal da regularização fundiária. In: Planejamento e Políticas Públicas. Brasília: IPEA, $2010, \mathrm{n}$. 34, jan/jun, pp. 310-311).
} 
da regularização fundiária. ${ }^{62}$

Essa relação entre regularização dominial e intervenção urbanística, ambas inseridas no conceito de regularização fundiária, fica ainda mais evidente quando a Lei em questão estabelece, em seu art. $53^{63}$, que projeto de intervenção ${ }^{64}$ passa a ser requisito para o início do processo de regularização fundiária.

Há, também, o reconhecimento de que dificilmente o aspecto dominial e a intervenção física, destinada a melhorar as condições de habitabilidade, acessibilidade e acesso a serviços públicos, acontecem de maneira sucessiva. Prevê, portanto, o art. 55, Parágrafo único, a possibilidade de realização de obras de implantação de infraestrutura básica e de equipamentos comunitários pelo Poder Público mesmo antes de concluída a regularização jurídica das situações dominiais dos imóveis.

Outro aspecto interessante de notar vem disciplinado pelo art. 47, inciso IX da Lei, incluído em 2011, pela Lei federal $\mathrm{n}^{\circ}$ 12.424. Segundo tal previsão, são etapas da regularização fundiária: as medidas jurídicas, as urbanísticas e as ambientais. Há uma clara procedimentalização do conteúdo de regularização fundiária, entendida agora como um conjunto de atos e ações intersetoriais. Aproxima-se, com isso, a regularização fundiária do conceito de política pública. ${ }^{65}$

No tocante aos destinatários da regularização fundiária, destaca-se que a recente Lei federal $n^{\circ} 11.977 / 09$ também traz alguns esclarecimentos que contribuem para o trabalho. Isso porque, a lei reconhece duas modalidades de regularização fundiária: (i) a de interesse social e (ii) a de interesse específico:

Art. $47[\ldots]$ VII - regularização fundiária de interesse social:
regularização fundiária de assentamentos irregulares ocupados,
predominantemente, por população de baixa renda, nos casos:

${ }^{62}$ Mesmo que essa interpretação já fosse possível apenas com o Estatuto da Cidade, como exposto anteriormente, com a nova normativa essa diretriz tornou-se mais clara.

63 “Art. 53. A regularização fundiária de interesse social depende da análise e da aprovação pelo Município do projeto de que trata o art. 51" (Lei do Programa Minha Casa, Minha Vida).

64 “Art. 51. O projeto de regularização fundiária deverá definir, no mínimo, os seguintes elementos: I - as áreas ou lotes a serem regularizados e, se houver necessidade, as edificações que serão relocadas; II - as vias de circulação existentes ou projetadas e, se possível, as outras áreas destinadas a uso público; III - as medidas necessárias para a promoção da sustentabilidade urbanística, social e ambiental da área ocupada, incluindo as compensações urbanísticas e ambientais previstas em lei; IV - as condições para promover a segurança da população em situações de risco, considerado o disposto no parágrafo único do art. $3^{\circ}$ da Lei $n^{\circ}$ 6.766, de 19 de dezembro de 1979; e V - as medidas previstas para adequação da infraestrutura básica." (Lei do Programa Minha Casa, Minha Vida).

${ }^{65} \mathrm{Cf}$. comentário na nota de rodapé 45 . 
a) em que a área esteja ocupada, de forma mansa e pacífica, há, pelo menos, 5 (cinco) anos;

b) de imóveis situados em ZEIS; ou

c) de áreas da União, dos Estados, do Distrito Federal e dos Municípios declaradas de interesse para implantação de projetos de regularização fundiária de interesse social;

VIII - regularização fundiária de interesse específico: regularização fundiária quando não caracterizado o interesse social nos termos do inciso VII.

Apesar de haver previsão da modalidade de regularização fundiária de interesse específico como uma possibilidade de atuação da Administração Pública, a Lei dispõe que por regularização fundiária urbana de interesse social entende-se aquela destinada à população predominantemente ${ }^{66}$ de baixa renda ${ }^{67}$.

Nota-se que, na definição de regularização de interesse social, a Lei 11.977/09 utilizase de outra expressão para identificar a hipótese de incidência: qual seja "assentamentos irregulares". Assim, a Lei prescreve por "assentamento irregular" como aquelas "ocupações inseridas em parcelamentos informais ou irregulares, localizadas em áreas urbanas públicas ou privadas, utilizadas predominantemente para fins de moradia” (art. 47, inciso VI).

Em relação a esse aspecto, porém, o dispositivo restringe a abrangência dada ao instituto da regularização fundiária urbana pelo Estatuto da Cidade. Como já indicado, o art. $2^{\circ}$ do Estatuto da Cidade prevê a possibilidade de a regularização fundiária ser aplicada a usos e a ocupações irregulares do solo e das edificações. Isso porque insere no conteúdo da regularização as irregularidades que não sejam, necessariamente, provenientes de parcelamentos irregulares, incluindo no rol as irregularidades das ou nas edificações, ou

\footnotetext{
${ }^{66} \mathrm{O}$ termo "predominantemente" decorre de uma situação fática encontrada em muitas comunidades que são eleitas para a implantação de programas de regularização fundiário de interesse social: nem todos os destinatários encontram-se naquilo que o programa define como sendo população de baixa renda. Nota-se que a lei tem a preocupação de conferir tal direito a comunidades na quais haja o predomínio de população de baixa renda, justamente para evitar que algumas exceções inviabilizem o direito de um conjunto maior de destinatários.

${ }^{67}$ Importa salientar que se trata de um termo cujo conteúdo varia de acordo com a época ou a fase econômica em que a política é implementada. Assim, a opção do legislador em manter esse conteúdo aberto tem justamente a finalidade de permitir que a Administração Pública adeque esse conteúdo ao momento em que a política será implementada. Há, porém, hipóteses que a legislação adota uma renda máxima para determinar a que camada da sociedade se destina a ação ou qual camada é considerada de baixa renda. São as hipóteses previstas no art. 18-A, $\S 1^{\circ}$, do Decreto-Lei $\mathrm{n}^{\circ}$ 9.760/46, alterado pela Lei $\mathrm{n}^{\circ}$ 11.481/07 (disciplina os bens imóveis da União), que considera regularização fundiária de interesse social aquela destinada a atender a famílias com renda familiar mensal não superior a 5 (cinco) salários mínimos, ou, ainda, na Lei no ${ }^{\circ} 11.124 / 05$ que cria o Fundo Nacional de Habitação de Interesse Social - FNHIS, na qual disciplina que, para a obtenção do acesso aos recursos do FNHIS, as ações devem ser destinadas à população com renda familiar mensal de até $\mathrm{R} \$ 1.050,00$ (mil e cinquenta reais).
} 
seja, irregularidades muito frequentemente encontradas em conjuntos habitacionais e nas habitações multifamiliares irregulares (cortiços).

Reduzindo ainda mais a esfera de aplicabilidade do instituto, a Lei estabelece que a regularização fundiária urbana de interesse social se aplica em apenas três situações: (i) na hipótese em que a área estiver ocupada de forma mansa e pacífica, há, pelo menos, 5 (cinco) anos; (ii) no caso de imóveis situados em ZEIS (Zonas Especiais de Interesse Social); ou (iii) na hipótese de áreas da União, dos Estados, do Distrito Federal e dos Municípios declaradas de interesse para implantação de projetos de regularização fundiária de interesse social.

Por fim, para completar a delimitação do tema em desenvolvimento, ressalta-se o que será considerado como "urbano".

Conforme dispõe o art. 47 da Lei $\mathrm{n}^{\circ}$ 11.977/09, incisos I e II, duas são as possibilidades previstas: (i) área urbana e (ii) área urbana consolidada. A primeira, mais ampla e que acaba por incluir a segunda, compreende "parcela do território, contínua ou não, incluída no perímetro urbano pelo Plano Diretor ou por lei municipal específica" e a segunda contempla outros elementos, quais sejam:

[...] parcela da área urbana com densidade demográfica superior a 50 (cinquenta) habitantes por hectare e malha viária implantada e que tenha, no mínimo, 2 (dois) dos seguintes equipamentos de infraestrutura urbana implantados: a) drenagem de águas pluviais urbanas; b) esgotamento sanitário; c) abastecimento de água potável; d) distribuição de energia elétrica; ou e) limpeza urbana, coleta e manejo de resíduos sólidos.

A Lei em análise aparentemente trata da regularização fundiária como um todo, mas deixa dúvidas se a intenção é mesmo essa. Em que pesem os evidentes avanços, que serão mais bem detalhados principalmente nos instrumentos por essa Lei inaugurados, e esforços no sentido de melhor disciplinar o tema, há em grande medida tão somente a delimitação de um procedimento específico de regularização fundiária, qual seja demarcação urbanística e a legitimação da posse, sendo que em relação a tais procedimentos a Lei é clara e bastante detalhada.

Tomando como base o ordenamento jurídico como um todo, porém, a regularização fundiária urbana de interesse social envolvem situações e mecanismos que vão muito além das hipóteses disciplinadas pela Lei do Programa Minha Casa, Minha Vida.

\subsection{Conceito adotado no trabalho}


Partindo, portanto, da concepção mais ampla do instituto da regularização fundiária urbana de interesse social, a dissertação não ficará adstrita à análise das medidas jurídicas voltadas à legalização do exercício da posse da população que ocupa irregularmente áreas urbanas, mas buscará inserir no estudo dos instrumentos que têm a finalidade de regularizar os assentamentos irregulares em seus aspectos também urbanísticos.

O conceito da regularização fundiária de interesse social contribuirá para a análise: (i) dos instrumentos jurídicos encontrados no Estatuto da Cidade aptos a serem utilizados para a concretização da regularização fundiária compreendida em sua concepção ampla; (ii) dos possíveis arranjos institucionais e contratuais que contribuam para a viabilização investimentos; (iii) dos aspectos críticos envolvidos na efetividade do instituto.

Importa destacar que há uma parcela de medidas que envolvem a compatibilização das ocupações às normas urbanísticas por meio da realização de intervenções físicas, abrangendo as residências, a abertura de vias, a implantação de redes de esgoto e sistema de água etc. $\mathrm{O}$ estudo de tais intervenções será abordado apenas no âmbito dos instrumentos jurídicos que contribuem para a implementação do conjunto dessas medidas como forma de atuação da Administração Pública, garantindo maior efetividade à regularização fundiária de interesse social.

Antes de indicar sinteticamente o conteúdo adotado nesta pesquisa, cumpre esclarecer algumas importantes delimitações que justificarão a abordagem que se pretende empreender.

Primeiramente, no tocante ao tipo de ocupação irregular, cumpre esclarecer que, apesar da Lei n ${ }^{\text {o }}$ 11.977/09 - Programa Minha Casa, Minha Vida - incluir no conceito de regularização fundiária de interesse social apenas os parcelamentos informais ou irregulares, entende-se que tal Lei deve ser interpretada em conjunto com o Estatuto da Cidade, que prevê a aplicabilidade da regularização fundiária ser aplicada a usos e a ocupações irregulares do solo e das edificações. Entende-se, com isso, que a regularização fundiária de interesse social pode ser aplicada tanto em casos de parcelamentos irregulares ou informais, quanto em situações em que as irregularidades se encontram inseridas nas edificações.

Além disso, as três situações previstas no art. 47, inciso VII, alíneas "a", "b" e "c" da Lei do Programa Minha Casa, Minha Vida são requisitos para a utilização apenas do 
instituto da demarcação urbanística e da legitimação da posse, tendo em vista que nem todos os instrumentos aptos a regularizar situações concertas estão sujeitos e tais critérios, e, mais uma vez, o ordenamento deve ser observado como um conjunto a ser harmonizado.

Feitas tais considerações e delimitações, a dissertação compreenderá, em linhas gerais, a regularização fundiária, abrangendo ações jurídicas destinadas à adequação das ocupações irregulares em relação à legalização da posse dos ocupantes, à flexibilização das normas referentes ao parcelamento, uso e ocupação para garantir a melhoria estrutural das ocupações e à urbanização das áreas ocupadas irregularmente, de interesse social, compreendida nesse conceito a população de baixa renda e incluindo as irregularidades relacionadas ao uso e ocupação do solo e das edificações, urbana, considerando o conceito de "área urbana" que engloba a "área urbana consolidada" para as hipóteses de regularização em Área de Preservação Permanente, no direito brasileiro.

\subsection{Síntese conclusiva do capítulo}

Este capítulo delineou o instituto da regularização fundiária urbana de interesse social, assumindo como base seus fundamentos, expressos no princípio da função social da propriedade urbana, pública ou privada, e do direito à moradia, e a amplitude conceitual a partir do referencial do ordenamento jurídico.

Considerando tal referencial, as conclusões sintetizam cinco aspectos fundamentais. O primeiro refere-se à apresentação da regularização fundiária urbana de interesse social como instrumento que se justifica na ordem jurídica a partir de sua disposição para garantir que a propriedade seja destinada a uma função social e para dar concretude ao direito à moradia.

Em segundo lugar, acerca da função social, foi possível constatar que: (i) a função social da propriedade não compreende apenas imposições negativas, mas também positivas, no sentido do proprietário buscar exercer seu direito de maneira mais compatível com a utilidade social; (ii) o conteúdo material da função social da propriedade urbana é delegado para esfera infraconstitucional, notadamente o Plano Diretor, mas há uma parcela desse conteúdo já definido no art. $183, \S 4^{\circ}$ da Constituição Federal; (ii.a) os termo "não edificado", "subutilizado" e "não utilizado" são distintos e compreendem, respectivamente, o solo que não é ocupado por nenhuma edificação; o imóvel que apresenta coeficiente ou 
índice de aproveitamento e taxa de ocupação inferiores ao exigido no Plano Diretor; e o uso ou destinação incompatível com o Plano Diretor; (ii.b) não há inconstitucionalidade no alargamento das hipóteses em que cabem as sanções previstas no art. $183, \S^{\circ}$ da Constituição Federal, pelo art. $5^{\circ}$ do Estatuto da Cidade, já que a própria Constituição confere ao Plano Diretor a tarefa de regular a função social da propriedade; (iii) os bens de domínio público são condicionados pelo Plano Diretor e pelos usos de interesse geral que são a eles reservados; e (iv) há direito subjetivo público ao cumprimento da função social diante de uma situação fática que a descumpra.

No âmbito do direito à moradia, em terceiro lugar, observa-se uma clara interface do instituto com os elementos inerentes ao conteúdo ao direito à moradia, sendo possível observar que quanto maior a amplitude que se dá à regularização fundiária, maior é a relação estabelecida entre tais elementos. Assim, afirma-se que a regularização fundiária urbana de interesse social acaba sendo um mecanismo destinado à concretização do direito à moradia.

O quarto aspecto refere-se à análise dos marcos normativos que delimitam o conteúdo da regularização fundiária urbana de interesse social, possibilitando as seguintes constatações: (i) a Lei de Parcelamento do Solo foi a primeira a reconhecer a necessidade de flexibilização dos parâmetros de parcelamento, uso e ocupação do solo para a regularizações; (ii) o Estatuto da Cidade apresenta um conceito de que não abrange a urbanização no conteúdo da regularização fundiária, apesar de reconhecer a relação entre ambas, mas engloba a possibilidade de fixação de exceções ou diferenças normativas no tocante à urbanização, uso e ocupação envolvendo irregulares do solo e das edificações; e (iii) a Lei do Programa Minha Casa Minha Vida expressa o conceito de regularização fundiária de um lado no sentido de ampliá-lo, já que inclui a urbanização no conteúdo, e de outro restringindo a aplicabilidade do instituto para situações específicas.

Por fim, o último aspecto se relaciona, portanto, com o ordenamento compreendido por esta dissertação que, em linhas gerais, considerará a regularização fundiária, abrangendo ações jurídicas destinadas à adequação das ocupações irregulares em relação à legalização da posse dos ocupantes, à flexibilização das normas referentes ao parcelamento, uso e ocupação para garantir a melhoria estrutural das ocupações e à urbanização das áreas ocupadas irregularmente, de interesse social, compreendida nesse conceito a população de baixa renda e incluindo as irregularidades relacionadas ao uso e ocupação do solo e das edificações, urbana, considerando o conceito de "área urbana" que 
engloba a "área urbana consolidada" para as hipóteses de regularização em Área de Preservação Permanente, no direito brasileiro.

Assim, percebe-se que a ampla conceituação nada mais faz do que reconhecer a abrangência e complexidade da problemática inerente aos processos de regularização fundiária urbana de interesse social. 


\section{CAPÍTULO II}

\section{ASPECTOS DA RELAÇÃO ENTRE O ESTADO E A REGULARIZAÇÃO FUNDIÁRIA URBANA DE INTERESSE SOCIAL}

Este capítulo tem a finalidade de analisar a relação que se estabelece entre o Estado brasileiro e a regularização fundiária urbana de interesse social, notadamente no tocante aos seguintes aspectos: (i) o exame acerca do papel do Estado na proliferação do acesso irregular ao solo urbano pela população de baixa renda, fato que acaba por ensejar políticas voltadas à regularização fundiária; e (ii) a análise da organização interfederativa inaugurada pela Constituição Federal de 1988 que disciplina as atribuições dos entes federados para a implementação da política pública de regularização fundiária urbana de interesse social.

No que se refere ao primeiro aspecto o estudo buscará, a partir do levantamento histórico, compreender algumas das razões que acabaram por intensificar as ocupações irregulares pela população de baixa renda, demonstrando de que forma o Estado contribuiu para esse processo, diante dos insuficientes projetos habitacionais propostos que acabaram por não interromper o processo de ocupação irregular nas cidades.

Acerca do segundo aspecto, a análise terá como objetivo a divisão de competências entre os entes federativos para a implementação da política de regularização fundiária urbana de interesse social, consideradas as atribuições legislativas e materiais, com o intuito de identificar: (i) a margem de atuação conferida pela Constituição Federal à União, aos Estados, ao Distrito Federal e aos Municípios; (ii) o papel de cada um dos entes da federação na estruturação da política pública de regularização fundiária; e (iii) eventual alteração na dinâmica interfederativa decorrente da forma como a legislação infraconstitucional relacionada ao tema detalhou a competência prevista na Constituição Federal.

\subsection{Histórico do acesso irregular à moradia pela população de baixa renda}

Levantamentos históricos sobre a formação das cidades indicam que a exclusão, refletida no território das cidades, e a proliferação de ocupações irregulares foram consequências de políticas de governo que, de maneira combinada ou isolada, não davam 
conta da demanda por moradia, dificultavam a produção legal de habitações e acabavam por não atingir a população mais carente de recursos.

Para demonstrar como o comportamento do Estado muitas vezes levou ao incremento da irregularidade ou simplesmente foi insuficiente, propõe-se analisar o histórico da legislação combinado com o momento político do país. Para tanto, o critério de seleção da legislação tem a finalidade de apresentar apenas aquelas que permitam identificar os marcos de alteração na postura estatal no sentindo de reconhecer a existência da problemática ou de criar novas alternativas na tentativa de solucioná-la. Salienta-se que esta análise adotará de maneira mais detalhada os eventos pós década de 1960, notadamente a partir do regime militar em 1964, tendo em vista que nos anos seguintes a maioria da população do país passou a viver nas cidades.

Antes disso, porém, cabe identificar brevemente alguns episódios que marcaram o início da exclusão relacionada ao acesso à moradia da população de baixa renda nas cidades.

Durante a chamada República Velha, período compreendido entre 1889 e 1930, iniciou-se a primeira etapa de industrialização no país, tendo como causa dois principais fatores. De um lado, a abolição da escravatura possibilitou que recursos anteriormente investidos na compra de escravos fossem disponibilizados para novos investimentos e, de outro, a crescente imigração de trabalhadores estrangeiros para a indústria do café expandiu a mão de obra assalariada, incrementando a parcela consumidora do país. Tais processos, aliados às condições degradantes de trabalho nas fazendas, ampliaram o deslocamento da população para as cidades de maneira acelerada, sem que o espaço urbano fosse preparado para receber esse contingente populacional. ${ }^{68}$

Com a urbanização, a única alternativa acessível no âmbito da moradia para a população de baixa renda era o aluguel de quartos nas casas de cômodo, cortiços e estalagens, que tinham como característica: ambientes reduzidos, congestionados, serviços sanitários comuns e infraestrutura precária. A provisão desse tipo de moradia era, inicialmente, realizada por pequenos investidores, sem qualquer intervenção do Estado, e chegava a propiciar ao "proprietário cerca de $50 \%$ a $100 \%$ de juros ao ano sobre o capital

\footnotetext{
${ }^{68}$ Na palavras de Céline Sanchs: "As estruturas agrárias anacrônicas, o desemprego aberto e oculto e as duras condições de vida no campo brasileiro, particularmente no Nordeste, conjugados à pressão demográfica, são fatores decisivos do êxodo rural. O 'push rural' tem um corolário: o 'pull urbano', o mito do 'Sul Maravilha' amplamente divulgado pela mídia, que permitia tentar a sorte no mercado de trabalho e ter acesso mais fácil à educação e aos serviços de saúde". (São Paulo: Políticas Públicas e Habitação Popular. São Paulo: Edusp, 1999, p. 37)
} 
investido". 69

Essa estrutura habitacional precária, aliada à falta de saneamento, aos altos índices de criminalidade e à insalubridade deram início, no final do século XIX, a uma atuação do Estado no sentido de promover políticas sanitárias nas cidades. Uma das finalidades das medidas, além de abrangerem a remodelação das áreas centrais e a criação de espaços públicos para melhorar a circulação do ar, foi a eliminação da concentração de moradias coletivas, retirando-as das áreas centrais e colocando-as nas periferias das cidades. Raquel Rolnik, ao expor o histórico da formação dos bairros operários em São Paulo, menciona:

[...] em 1894, o primeiro Código Sanitário Estadual adotou um posicionamento mais rígido em relação às habitações coletivas: elas foram proibidas e as existentes teriam de desaparecer, assim como casas subdivididas e as vilas operárias. [...] formulou-se pela primeira vez, como resposta à gravidade da situação, a proposta de incentivar empresários a construir casas operárias 'higiênicas' em terrenos situados numa raio de 15 quilômetros da cidade. ${ }^{70}$

Com isso, passaram a conviver duas alternativas de acesso da população de baixa renda à moradia: (i) a locação de cômodos, cortiços e estalagens que apesar da política empreendida no sentido de eliminá-las, continuavam existindo; e (ii) a posse, por meio da locação ou não, de terrenos na periferia das cidades, também caracterizados pela ausência de infraestrutura urbana.

Reconhecendo a importância de interferir em alguma medida nas práticas vigentes na época acerca dos acordos de locação, o Estado editou a primeira Lei do Inquilinato - Decreto $n^{o} 4.403 / 1921$, regulando prazos mínimos de vigência de contratos de locação e especificando as hipóteses em que o despejo seria cabível e as garantias do locatário nessa seara. ${ }^{71}$

Na mesma época, mais precisamente em 1916, houve a aprovação do primeiro Código Civil brasileiro. Com a finalidade de reforçar o previsto na Lei de Terras de 1850, que estabelecia a compra como única forma de aquisição da propriedade ${ }^{72}$ e buscando

69 JANUZZI, 1909, p. 41, apud RIBEIRO, 1996, p. 208 apud BEINENSTEIN, Regina. Redesenho Urbanístico e Participação Social em Processos de Regularização Fundiária. Tese de doutorado. Faculdade de Arquitetura e Urbanismo. Universidade de São Paulo, 2001, p. 16.

${ }^{70}$ ROLNIK, Raquel. A Cidade e a Lei. 3. ed. São Paulo: FAPESP e Studio Nobel, 2003, p.123-124.

71 “Art. $8^{\circ}, \S 2^{\circ}$ Nos executivos por aluguel de predios urbanos não poderão ser penhorados os bens indispensaveis dos inquilinos, taes como cama, mesa, vestuarios seus e de sua familia, utensilios e ferramentas de sua apparelhagem profissional e provisões de comida até o minimo de 300\$000." (Decreto 4.403/1921)

${ }^{72}$ Lei 601/1850, “Art. $1^{\circ}$ Ficam prohibidas as acquisições de terras devolutas por outro titulo que não seja o de compra." Destaca-se que, antes da Lei de Terras, permanecia vigente o sistema das sesmarias que legitimava a propriedade pelo uso e não pela compra. 
ampliar as garantias decorrentes da propriedade aos proprietários, o direito à propriedade foi ali previsto de maneira absoluta e individualista, ou seja, sem qualquer condicionamento em relação a sua função social, como era na época preconizado.

Assim, além da propriedade da terra ter sido dificultada quando a compra passou a ser o principal mecanismo de acesso, ${ }^{73}$ a propriedade não era ainda encarada como algo inserido em um contexto social que vinculava seu exercício. Ainda que existisse a figura da usucapião no Código Civil, o art. 550 previa um período de 30 (trinta) anos ininterruptos sem oposição e, ainda, a necessidade de reconhecimento em juízo, afastando a parcela da população de baixa renda da utilização do mecanismo, em função do desconhecimento, já que o país tinha cerca de $80 \%$ da população analfabeta, e do acesso à justiça depender da posse de recursos, inexistindo gratuidade no sistema judiciário à época.

No período que se seguiu entre 1930 e 1964, diante da ineficácia das medidas até então empreendidas, o Estado passou a se fazer mais presente. Em relação aos aluguéis, pode-se observar uma interferência mais agressiva, incluindo o congelamento dos valores cobrados pelo locador. ${ }^{74}$ No que toca aos loteamentos, por meio do Decreto-Lei $\mathrm{n}^{\mathrm{o}}$ 58/1937, o Estado passou a regular a venda de loteamentos para pagamento em prestações, medida que acabou por estimular o desenvolvimento de um mercado voltado para atender à população da baixa renda nas periferias. De maneira mais direta, observou-se a atuação mais do Estado na promoção de habitações sociais, adotando como modelo a casa própria, por meio do Decreto-Lei no 9.218/1946 que criou a Fundação da Casa Popular, que se seguiu aos Institutos e Caixas de Aposentadorias e Pensões nos quais já abrangiam a possibilidade de destinação de recursos para moradia de seus associados. ${ }^{75}$

Tais iniciativas, contudo, não davam conta da demanda crescente por moradia. Dados indicam que durante o período de existência da Fundação da Casa Própria, a estimativa da demanda por moradia atingiu 3.600.000 (três milhões e seiscentas mil) moradias, sem contar favelas e cortiços. A Fundação produziu apenas 143 conjuntos

\footnotetext{
${ }^{73}$ Em linhas gerais, antes de 1850, o sistema vigente era o das sesmarias no qual o exercício da posse e a utilização do bem para fins agrícolas eram razões suficientes a justificar o título de domínio.

${ }^{74}$ Nesse sentido, assim previa o Decreto-Lei no 1598/1942: “art. $1^{\circ}$ Durante o período de dois anos, a contar da vigência desta lei, não poderá vigorar em todo o território Nacional, aluguel de residência, de qualquer natureza, superior ao cobrado a 31 de dezembro de 1941, sejam os mesmos ou outros o locador ou sublocados e o locatário ou sub-locatário, seja verbal ou escrito o contrato de locação ou sub-locação.”

75 “Art. $1^{\circ}$. Os Institutos e Caixas de Aposentadorias e Pensões que tiverem saldos acumulados, convertidos, ou não, em títulos da Dívida Pública, e cujo patrimônio seja superior a 500:000\$000 (quinhentos contos de réis), poderão empregar até $50 \%$ (cincoenta por cento) daqueles saldos no financiamento para a aquisição, por compra ou construção, de prédios para moradia dos seus associados, de preferência os de família de prole, numerosa, o para construção de séde própria." (Decreto $\left.n^{\circ} 1.749 / 1937\right)$.
} 
habitacionais que representavam um total de 18.132 (dezoito mil cento e trinta e duas) unidades. ${ }^{76}$ Além das políticas voltadas à regulação dos aluguéis dificultarem o acesso da população de baixa renda ${ }^{77}$ e praticamente inviabilizarem o mercado de aluguéis, já que o congelamento estava associado a um período de elevados índices de inflação, a proliferação dos loteamentos nas periferias era marcada pela ausência da presença estatal e do provimento de infraestrutura urbana.

Aliado a isso, é possível identificar outros fenômenos que contribuíram ainda mais para esse processo de exclusão refletida no território, tomando como base de exemplo o início das concepções acerca do planejamento urbano no Município de São Paulo, que entendia o planejamento como algo que pudesse ser concretizado por meio da definição de zonas específicas. Entretanto, essa definição de zonas seguia a lógica de estabelecer reservas de mercado, preservando ou elevando os valores das propriedades com a finalidade de atender à população de alta renda da cidade.

Conforme demonstra Sarah Feldman:

Entre 1954 e 1957 zonas foram delimitadas numa extensão que vai do Alto da Lapa à avenida Morumbi, incluindo todos os loteamentos da Companhia City realizados segundo o padrão das cidades-jardins inglesas, e outros bairros adjacentes. O processo de definição dessas zonas mostra que, ao mesmo tempo que se busca manter o padrão original dos bairros residenciais - monofuncionais, casas isoladas, amplos espaços verdes, a legislação acomoda também possibilidade de verticalização e a introdução de outros usos - atendendo às demandas dos setores mais valorizados das cidades e aos efeitos do boom imobiliário que se dá nos anos de $1940 .^{78}$

Observa-se, ainda, que a concentração dos investimentos públicos ocorria de modo a favorecer a valorização imobiliária das regiões destinadas à construção de moradias de alto padrão. A Companhia City em São Paulo, por exemplo, atuava por meio da ingestão de recursos em empresas concessionárias de energia, gás e transporte, recebendo como contrapartida a realização prioritária de obras públicas nas áreas em que se localizam seus loteamentos, para usufruir da valorização que tais investimentos gerariam. Dentre esses benefícios, destaca-se a aprovação de leis Municipais, como o Acto 127, de 1931, que

\footnotetext{
${ }^{76}$ BIENENSTEIN, Regina. Redesenho Urbanistico e Participação Social em Processos de Regularização Fundiária. Tese de doutorado. Faculdade de Arquitetura e Urbanismo. Universidade de São Paulo, São Paulo, 2001, p. 35.

${ }^{77}$ BONDUKI, Nabil. Origens da Habitação Social no Brasil. In: Análise Social, vol. XXIX 1994, p. 729.

${ }^{78}$ FELDMAN, Sarah. Planejamento e zoneamento: São Paulo 1947-1972. São Paulo: FAPESP e EDUSP, 2005, p. 118.
} 
garantiam o padrão dos empreendimentos da Companhia. ${ }^{79}$

Tais práticas desconsideram a existência de uma camada da população hipossuficiente, principalmente em relação aos aspectos econômicos, para disputar os espaços mais bem servidos de serviços e equipamentos públicos. Apesar de serem somente exemplos, é interessante observar como tais políticas criaram um ambiente propício para o aprofundamento das desigualdades e da proliferação das formas precárias de moradia.

Diante desse quadro, nas palavras de Nabil Bonduki:

[...] se desenvolvem novas "alternativas habitacionais" baseadas na redução significativa, ou mesmo na eliminação, do pagamento regular e mensal de moradia: a favela e a casa própria autoconstruída ou autoempreendida em loteamentos periféricos carentes de infraestrutura urbana. $^{80}$

Sendo assim, constatou-se a proliferação de favelas e loteamentos periféricos, principalmente nas grandes metrópoles. No tocante às favelas, no Rio de Janeiro, entre 1948 a 1950, a população vivendo em favelas aumentou de 7\% (sete por cento) para 10\% (dez por cento) da população da cidade, representando em números absolutos um incremento de 138.837 (cento e trinta e oito mil oitocentas e trinta e sete) para 169.305 (cento e sessenta e nove mil trezentas e cinto) pessoas. Em Belo Horizonte, no ano de 1955, havia 36.432 (trinta e seis mil quatrocentas e trinta e duas) pessoas vivendo em favelas. Em São Paulo, em 1957, o número atingiu a estimativa de 50.000 (cinquenta mil) e, em Salvador, durante 1959 e 1960, 8.978 (oito mil novecentos e setenta e oito) viviam nos chamados alagados. ${ }^{81}$

Ao mesmo tempo, entretanto, em que se expandiam as favelas nas áreas urbanas, ampliavam-se de um lado a repressão a essa forma de ocupação do espaço e, de outro, certas iniciativas isoladas no sentido melhorar as condições de habitabilidade. A repressão pode ser observada na medida em que, além da existência de leis que proibiam a construção de favelas, foram criadas no Rio de Janeiro as Comissões de Extinção de Favelas. No sentido oposto, surgiam fundações, como a Fundação Leão XII no Rio de Janeiro, que atuavam com a finalidade de realizar projetos de urbanização das favelas, levando principalmente rede de energia elétrica. ${ }^{82}$

\footnotetext{
${ }^{79}$ FELDMAN, op. cit., p. 155.

${ }^{80}$ BONDUKI, op. cit., p. 729.

${ }^{81}$ BIENENSTEIN, op. cit., p. 28.

${ }^{82}$ BIENENSTEIN, op. cit., p. 36.
} 
Todo esse contexto de exclusão, acompanhado por um processo de sindicalização de trabalhadores e organização de associações de bairro, característicos do período populista que antecedeu o regime militar, passaram a ser identificados como problemáticos quando do início do regime autoritário, tendo em vista a potencialidade dos conflitos sociais que poderia gerar.

Assim, percebe-se como uma das primeiras iniciativas do regime militar a estruturação de um modelo centralizado para dar conta da questão habitacional, por meio da aprovação da Lei federal $n^{\circ} 4.380 / 1964$ que criou o Banco Nacional da Habitação (BNH), o Sistema Financeiro da Habitação (SFH), as sociedades de crédito imobiliário, as letras imobiliárias e o Serviço Federal de Habitação e Urbanismo ${ }^{83}$. A intenção era criar um sistema capaz de financiar a produção em grande escala e ao mesmo tempo ter maior conhecimento acerca da problemática, já que o Serviço Federal de Habitação e Urbanismo tinha como finalidade tanto a produção de dados acerca da situação habitacional do país, como também o incentivo à formação de fundações e associações ou a investigação tecnológica voltada à habitação e ao urbanismo. ${ }^{84}$

A captação de recursos ficava a cargo do $\mathrm{BNH}$, do $\mathrm{SFH}$, das sociedades de crédito imobiliário, as associações de poupança e empréstimo; e das Caixas Econômicas

${ }^{83}$ O Serviço Federal de Habitação e Urbanismo foi inspirado no documento produzido principalmente pelo Instituto de Arquitetos Brasileiros como resultado do Seminário Nacional de Habitação e Reforma Urbana em 1963.

84 “Art. 55. O Serviço Federal de Habitação e Urbanismo terá as seguintes atribuições: (a) promover pesquisas e estudos relativos ao deficit habitacional, aspectos do planejamento físico, técnico e sócioeconômico da habitação; (b) promover, coordenar e prestar assistência técnica a programas regionais e municipais de habitação de interêsse social, os quais deverão necessàriamente ser acompanhados de programas educativos e de desenvolvimento e organização de comunidade; (c) fomentar o desenvolvimento da indústria de construção, através de pesquisas e assistência técnica, estimulando a iniciativa regional e local; (d) incentivar o aproveitamento de mão-de-obra e dos materiais característicos de cada região; (e) estimular a organização de fundações, cooperativas, mútuas e outras formas associativas em programas habitacionais, propiciando-lhes assistência técnica; (f) incentivar a investigação tecnológica, a formação de técnicos, em qualquer nível, relacionadas com habitação e urbanismo; (g) prestar assistência técnica aos Estados e Municípios na elaboração dos planos diretores, bem como no planejamento da desapropriação por interêsse social, de áreas urbanas adequadas a construção de conjuntos habitacionais; (h) promover, em colaboração com o Instituto Brasileiro de Geografia e Estatística, a realização de estatísticas sôbre a habitação no país; (i) (Vetado); (j) prestar assistência técnica aos Estados, aos Municípios e às emprêsas do país para constituição, organização e implantação de entidades de caráter público, de economia mista ou privadas, que terão por objetivo promover a execução de planos habitacionais ou financiá-los, inclusive assisti-los para se candidatarem aos empréstimos do Banco Nacional da Habitação ou das sociedades de crédito imobiliário; (l) prestar assistência técnica na elaboração de planos de emergência, intervindo na normalização de situações provocadas por calamidades públicas; $(\mathrm{m})$ estabelecer normas técnicas para a elaboração de Planos Diretores, de acôrdo com as peculiaridades das diversas regiões do país; (n) assistir aos municípios na elaboração ou adaptação de seus Planos Diretores às normas técnicas a que se refere o item anterior." (Texto original da Lei federal n 4380/1964) 
Federais $^{85}$, por meio da poupança voluntária de letras imobiliárias e cadernetas de poupança. A produção das moradias ficava a cargo de uma articulação entre prefeituras, responsáveis pela urbanização da área onde seria construído o conjunto habitacional; Companhias Estaduais de Habitação ${ }^{86}$, que forneciam terreno próprio ou adquirido no mercado e, ainda, fiscalizavam as obras; e a iniciativa privada, por meio ou não de cooperativas. A construção dos conjuntos era realizada direta ou indiretamente, pela prefeitura e, ainda, pelas Companhias Estaduais de Habitação e pela iniciativa privada, que a Lei federal $\mathrm{n}^{\mathrm{o}} 4.380 / 1964$ encarregou da "promoção e execução de projetos de construção de habitações segundo as diretrizes urbanísticas locais ". 87

Dentre os objetivos dessa nova política habitacional, além de aspectos relacionados ao desenvolvimento da indústria da construção civil e o aumento do emprego, estava a tentativa de investir em um programa voltado para a população de baixa renda e, com isso, ver erradicada a ocupação irregular que tinha como representante a favela e congregava tensões sociais e organizações populares, às quais o regime instaurado pretendia eliminar, conforme preconiza o art. $4^{\circ}$, inciso I da Lei federal $n^{\circ} 4.380 / 1964$.

A política do BNH estava voltada para faixas de renda baixa, tendo a Lei federal $n^{\circ}$ 4.380/1964 fixado os limites dos valores unitários das habitações, sendo que, no mínimo, $70 \%$ (setenta por cento) dos recursos deviam ser destinados para habitações de valor unitário inferior a 60 (sessenta) vezes o maior salário-mínimo mensal vigente no país e, no máximo, $15 \%$ (quinze por cento) poderia ser aplicado em habitações de valor unitário compreendido entre 200 (duzentas) e 300 (trezentas) vezes o maior salário-mínimo mensal vigente no país. ${ }^{88}$ Tais limites acabavam por atingir faixas de renda de 1 (um) a 6 (seis) salários mínimos, sendo o foco da política a faixa entre 1 (um) e 3 (três) salários mínimos. ${ }^{89}$

O grande problema do modelo, no entanto, foi sua financiabilidade, na medida em

\footnotetext{
${ }^{85}$ Conforme previsto no Decreto ${ }^{0} 55.279 / 1964$.

${ }^{86}$ As Companhias Estaduais de Habitações foram criadas ao longo das décadas de 50 e 60, tendo ganhado destaque no regime militar como executoras das políticas traçadas pelo governo federal, na época.

${ }^{87}$ BIENENSTEIN, op. cit., p. 45.

${ }^{88}$ Tais condições foram alteradas em 1965 , por meio da Lei $\mathrm{n}^{\circ} 4864$, que passou a estabelecer o seguinte: "Art. 11. Os recursos destinados ao setor habitacional pelas entidades estatais, inclusive sociedades de economia mista de que o Poder Público seja majoritário, distribuir-se-ão, permanentemente, da seguinte forma: I - em habitações de valor unitário inferior a 100 (cem) vezes o maior salário-mínimo mensal, vigente no País, uma percentagem mínima dos recursos a ser fixada, bienalmente, pelo Banco Nacional de Habitação, em função das condições do mercado e das regiões, e por instituição ou tipo de instituição. II - em habitações de valor unitário compreendido entre 300 (trezentas) e 400 (quatrocentas) vezes o maior salário-mínimo, vigente no País, no máximo, 20\% (vinte por cento) dos recursos, vedadas as aplicações em habitações de valor unitário superior a 400 (quatrocentas) vezes o maior salário-mínimo citado.”

${ }^{89}$ BIENENSTEIN, op. cit., p. 44.
} 
que a faixa de beneficiário mais carente não dava conta de honrar as prestações assumidas, que, além de elevadas, estavam inseridas em um contexto de inflação e instabilidade da economia e, conforme a própria Lei federal no 4.380/1964 prevê no art. 5, os contratos de vendas, contratos de construção de habitações para pagamento a prazo ou contratos de empréstimos para aquisição ou construção de habitações poderiam prever o reajustamento das prestações mensais de amortização e juros. Como não podia ser diferente, sem o pagamento, o sistema entraria em colapso. A alternativa acabou sendo privilegiar a faixa de renda que daria conta do pagamento das prestações. Alternativa essa, porém, que desconfigurava aquilo que se pretendia com o a criação do sistema. ${ }^{90}$

Tal constatação fez com que o governo lançasse outros programas para sanar o déficit habitacional e reforçar a necessidade de atingir a população de baixa renda. Foram eles: (i) II Plano Nacional de Habitação Popular (PLANHAP), que atingiu a marca de 100.000 (cem mil) moradias na década de 1980; (ii) Programa de Financiamento de Lotes Urbanizados (PROFILURB), destinado a melhorar as condições de saneamento e infraestrutura básica; (iii) Programa de Financiamento de Material de Construção, tendo como objetivo estimular a autoconstrução como alternativa; e (iv) Programa de Erradicação de Sub-habitações, o único programa voltado a melhorar as condições das habitações, sem que isso envolvesse a realocação da população em outra área da cidade. ${ }^{91}$

No bojo de tais programas, é possível observar certa alteração na postura do Estado, tendo em vista a clara intenção em investir na permanência da população no local da

\footnotetext{
${ }^{90}$ Conforme identifica a Exposição de Motivos n. 4/1974, que propunha alterações no SFH: "Em resumo, os principais fatores que têm contribuído para uma oferta pouco satisfatória de habitações, especialmente para as camadas de população de renda mais baixa, alinham-se a seguir: (i) condições de financiamento aos mutuários finais, resultando em prestações acima da real capacidade de endividamento, especialmente para as faixas de renda familiar baixa e média; (ii) exigência, em alguns casos, de níveis de poupança inadequados; (iii) capacidade econômica limitada e potencial financeiro aquém do desejável dos Agentes que atuam nas faixas de rendimentos inferiores, especialmente as Companhias de Habitação Popular - COHABs, em decorrência de perceberem remuneração insuficiente para os seus serviços e riscos; (iv) a falta de uma organização eficiente das COHABs, de um modo geral, como entidades de Poder Público, Governos Estaduais e/ou Municipais, carecendo de instrumentos específicos de melhor racionalidade. Por outro lado, o fato das COHABs serem justamente organismos pertencentes a Estados ou Municípios, exige integral comprometimento das Unidades da Federação nos programas de habitação popular; (v) dificuldades de obtenção de Agentes Financeiros que atuem nas atuais faixas de financiamento entre Cr\$ $32.000,00$ e Cr\$ 90.000,00 em virtude da maior atratividade pelos empreendimentos de maior valor unitário, em face de maiores rendimentos e menores riscos; ( $v$ ) falta de economia de escala de uma parte dos Agente que integram o Sistema Brasileiro de Poupança e Empréstimo - SBPE, especialmente dos que não atuam nos principais centros urbanos do País; (vi) dificuldades financeiras por parte dos Estados no tocante à sua participação de infraestrutura e de equipamentos comunitários necessários à implementação do Plano Nacional de Habitação Popular - PLANHAP; (vii) elevação em termos reais, no custo dos fatores de produção da Habitação, basicamente de materiais de construção, e, como primeira consequência de um período anormal inflacionário, uma alta exagerada no custo dos terrenos, em proporção superior ao crescimento salarial."

${ }^{91}$ BIENENSTEIN, op. cit., p. 47.
} 
ocupação, seja por meio do provimento de infraestrutura ou do estímulo à autoprodução e, ainda, a melhoria da qualidade das habitações já construídas. Seguindo essa lógica que passou a ser observada no governo federal, durante a década de 1980, antes mesmo da Constituição de 1988, alguns Municípios deram início a políticas que incluíam desapropriação por interesse social, delimitação de áreas especiais de interesse social e urbanização de favelas, tendo como foco a regularização fundiária das ocupações no local onde se situavam. ${ }^{92}$

Ainda com toda essa estrutura, o modelo do BNH não logrou o êxito que pretendia e a demanda por moradia para a população de baixa renda nas cidades só crescia. ${ }^{93}$ Além das ocupações em favelas, que em grande medida já partiam de uma ilegalidade inerente ao modelo de ocupação, permanecia viável a moradia por meio dos loteamentos periféricos, não necessariamente ilegais a priori.

Em 1979, com a aprovação da Lei federal $n^{\circ}$ 6.766, grande parte da produção dos loteamentos periféricos passou para a ilegalidade. Conforme destacado anteriormente, em diversos aspectos, referido marco normativo representou um avanço. Porém, ao estabelecer regras para todos os loteamentos, não apenas àqueles que seriam pagos em prestações, vinculando loteamentos à implementação de infraestrutura urbana, delimitando os tamanhos dos lotes, prevendo o registro e a aprovação de projetos de loteamento e desmembramento, acabava por colocar na ilegalidade todo o restante das produções que atendiam à população de baixa renda e não necessariamente seguiam os parâmetros recém-definidos. ${ }^{94}$

Não se trata de defender a manutenção de moradias sem infraestrutura urbana, mas de constatar que a lei excluiu o acesso pela via legal sem criar mecanismos para que algo fosse efetivado ou contemplado no âmbito da produção popular da moradia, o que acabava por simplesmente colocar essa alternativa na ilegalidade. Além disso, a nova legislação tipificou crimes relacionados à promoção e à venda de loteamentos e desmembramentos em desconformidade com as previsões legais. A intensificação das penalidades denota que

\footnotetext{
92 São exemplos o PREZEIS, em Recife, analisado no tópico destinado às ZEIS.

${ }^{93}$ Nesse sentido, Maria Paula Dallari Bucci, citando Azevedo e Andrade, aponta: “A comparação dos dados sociais re;ativos à habitação entre 1970 e 1976 já apontava para a conclusão de que o BNH não lograra inverter a curva descendente do agravamento da situação domiciliar no Brasil. Embora superior às políticas habitacionais anteriores, levadas adiante pela Fundação da Casa Popular e pelos Institutos de Pensões, o desempenho do BNH, especialmente se considerada a relação quantitativa entre oferta de unidades construídas e a demanda, é modesto no aumento do de habitações disponíveis." (Cooperativas de Habitação no Direito Brasileiro. Saraiva: São Paulo, 2003, p. 60-61)

${ }^{94}$ MARICATO, Ermínia. Metrópole na periferia do capitalismo: ilegalidade, desigualdade e violência. São Paulo: Hucitec, 1996, p. 47, apud BIENENSTEIN, op. cit., p. 54.
} 
o mercado vinha se desenvolvendo sem muito controle do Estado.

Após a extinção no BNH, em 1986, observou-se uma desarticulação de todo a estrutura institucional criada pelo antigo modelo e o Ministério do Desenvolvimento Urbano, criado em 1985, mudou de nome diversas vezes até ser transformado, no ano de 1989, na Secretaria Especial de Habitação e Ação Comunitária. Apesar dos problemas habitacionais continuarem crescentes, o espaço institucional no âmbito federal para tratar a questão é reduzido.

Com isso, até 1995, a política habitacional federal não havia sido consolidada, ainda que alguns programas federais como o Programa de Cooperativas Habitacionais, Programa de Habitação Popular (PROHAP), Plano de Ação Imediata para Habitação (PAIH), Morar Município, Habitar Brasil tivessem sido implementados. ${ }^{95}$ Cumpre salientar que, se por um lado houve uma desarticulação no âmbito federal, por outro tal ausência ou desarticulação da política na esfera federal possibilitou uma maior autonomia dos Estados e Municípios na formulação e execução de políticas habitacionais, fato que acabou dando margem ao aparecimento de iniciativas pioneiras no âmbito da regularização fundiária de interesse social, conforme mencionado.

Durante o governo de Fernando Henrique Cardoso, alguns programas foram criados por meio da Caixa Econômica Federal: (i) Pró-moradia, destinado à população de baixa renda situada em área de risco; (ii) Conclusão de Empreendimentos Habitacionais que tinha como finalidade realizar investimento para recuperar ou concluir conjuntos habitacionais já construídos com recursos do FGTS e, ainda, construir novos conjuntos habitacionais; (iii) Crédito Direto ao Cidadão e Cartas de Crédito, ambas no sentido de fornecer crédito para o comprador e não apenas ao produtor da moradia, sendo que a primeira contemplava a compra de materiais de construção e a aquisição de imóvel, enquanto que a segunda era destinada ao financiamento de habitações novas ou usadas, reformas ou lotes urbanizados.

Com essa terceira vertente, o governo esperava ampliar o acesso à moradia, já que ampliaria o poder de compra da população. Entretanto, conforme esclarece Tachner: "Se o setor de construção civil não fosse oligopolizado, isto poderia suceder. Não parece possivel. Pelo contrário, injetando-se dinheiro no mercado, existe grande chance dos

${ }^{95}$ BIENENSTEIN, op. cit., pp. 59-60. 
preços subirem. ${ }^{, 96}$

Outro aspecto marcante relaciona-se com as diretrizes do Fundo Monetário Internacional que acabaram pautando em alguma medida as políticas do governo da época, principalmente os investimentos em setores sociais estratégicos. Assim, as Resoluções 2668 e 2.682, ambas editadas pelo Banco Central em 1999, dificultaram o crédito habitacional, na medida em que a primeira estabelece regras que restringem operações de crédito com órgãos e entidades do setor público e a segunda estabelece regramento acerca da classificação de riscos envolvendo o tomador de empréstimo, exigindo maior segurança às instituições financeiras. Segundo Ermínia Maricato:

Essa última medida ignora que o empréstimo habitacional se ampara em hipotecas e ignora mais ainda que o financiamento habitacional no Brasil não atinge a população que ganha menos de 12 salários mínimos, o que significa deixar de fora do mercado e até mesmo dos empréstimos públicos até $70 \%$ da população. ${ }^{97}$

Todavia, em que pese o tais dificuldades durante o governo do Fernando Henrique Cardoso, um importante marco deste período foi a aprovação, em 2001, do Estatuto da Cidade, no qual diversos mecanismos são positivados e se inicia uma nova fase na ordem jurídica para tratar a problemática das ocupações irregulares e da demanda por moradia no ambiente urbano.

No governo Lula, houve uma tentativa de fortalecer, de início, o aspecto institucional das políticas voltadas às cidades. Isso se deu claramente com a criação do Ministério das Cidades já em 2003, com a função de atuar em temas envolvendo os problemas centrais vivenciados pelas cidades, como habitação, saneamento e transporte. $^{98}$

\footnotetext{
${ }^{96}$ Favelas e Cortiços no Brasil: 20 anos de pesquisas e políticas. In: Cadernos de Pesquisa do LAP, São Paulo: FAUUSP, 1997, n.18, mar/abril, p. 64, apud. BIENENSTEIN, op. cit., p. 62.

${ }^{97}$ MARICATO, Ermínia. Brasil, cidades: alternativas para a crise urbana. Petrópolis: Editora Vozes, 2011, p. 100.

98 “Art. 27 Os assuntos que constituem áreas de competência de cada Ministério são os seguintes: [...] III Ministério das Cidades: a) política de desenvolvimento urbano; b) políticas setoriais de habitação, saneamento ambiental, transporte urbano e trânsito; c) promoção, em articulação com as diversas esferas de governo, com o setor privado e organizações não-governamentais, de ações e programas de urbanização, de habitação, de saneamento básico e ambiental, transporte urbano, trânsito e desenvolvimento urbano; d) política de subsídio à habitação popular, saneamento e transporte urbano; e) planejamento, regulação, normatização e gestão da aplicação de recursos em políticas de desenvolvimento urbano, urbanização, habitação, saneamento básico e ambiental, transporte urbano e trânsito; f) participação na formulação das diretrizes gerais para conservação dos sistemas urbanos de água, bem como para a adoção de bacias hidrográficas como unidades básicas do planejamento e gestão do saneamento;dando início a institucionalizar políticas." (Lei federal $\mathrm{n}^{\circ} 10.683 / 2003$ )
} 
Nessa linha, observa-se a criação do Conselho das Cidades em 2004, órgão deliberativo e consultivo vinculado ao Ministério que apresenta uma representação heterogênea, com membros da sociedade civil e membros do poder público federal e de alguns Estados. ${ }^{99}$ Em 2005, o governo criou o Sistema Nacional de Habitação de Interesse Social e o Fundo Nacional de Habitação de Interesse Social, que passaram a conviver juntamente com o Sistema Financeiro da Habitação (SFH) já existente, inaugurando uma nova fase de implementação de políticas federais no setor da habitação, notadamente em relação à regularização fundiária de interesse social.

O primeiro programa destinado especificamente para regularização fundiária de interesse social que merece destaque foi a "Programa Nacional de Apoio à Regularização Fundiária Sustentável” formulado pelo Ministério das Cidades em 2003. Entretanto, apesar do programa adotar uma concepção ampliada do conceito de regularização fundiária de interesse social, articulando legalização da posse, urbanização e integração das áreas e comunidades, uma conjuntura estrutural interferiu na estratégia original. Isso porque, o Programa Nacional de Regularização Fundiária foi concebido na Secretaria Nacional de Programas, mas a gestão dos recursos do BID e do orçamento da União para programas habitacionais era gerida por outra secretaria, a Secretaria Nacional de Habitação que herdou o Programa Habitar Brasil. Assim, ainda que houvesse uma ampla concepção da regularização fundiária sendo difundida pelo "Programa Nacional de Apoio à Regularização Fundiária Sustentável”, os recursos para implementar a parcela relacionada à urbanização estavam concentrados em outra secretaria e, portanto, em outros programas de governo. ${ }^{100}$ Sendo assim, em 2003 deu-se início ao Programa Papel Passado, por meio do qual o governo federal deu cabo ao programa de regularização fundiária de interesse

\footnotetext{
${ }^{99} \mathrm{O}$ art. 3 de seu regimento interno prevê uma série de atribuições, dentre as quais se destacam: I- propor programas, instrumentos, normas e prioridades da Política Nacional de Desenvolvimento Urbano; IIacompanhar e avaliar a implementação da Política Nacional de Desenvolvimento Urbano, em especial os programas relativos à política de planejamento e gestão do solo urbano, de habitação, de saneamento ambiental, de mobilidade e transporte urbano e metropolitano, e recomendar as providências necessárias ao cumprimento de seus objetivos; III- propor a edição de normas gerais de direito urbanístico e manifestar-se sobre propostas de alteração da legislação pertinente; [...] VI- promover a cooperação e a ação federativa entre os governos da União, dos Estados, do Distrito Federal e dos Municípios e a sociedade civil na formulação e execução da Política Nacional de Desenvolvimento Urbano; [...] XII- propor diretrizes e critérios para a distribuição regional e setorial do orçamento anual e do plano plurianual do Ministério das Cidades.

${ }^{100}$ FERNANDES, Edésio. Princípios, Bases e Desafios de uma Política Nacional de Apoio à Regularização Fundiária Sustentável. In: ALFONSIN, Betânia; FERNANDES, Edésio. Direito à Moradia e Segurança da Posse no Estatuto da Cidade, Belo Horizonte: Editora Fórum, 2004, p. 330.
} 
social, que tinha como finalidade apenas a legalização da posse. ${ }^{101}$

Outra importante vertente do governo federal no tocante à regularização fundiária de interesse social deu-se no âmbito da Secretaria do Patrimônio da União (SPU), que passou a ter como diretriz mais acentuada a destinação de terras da União à realização de processos de regularização fundiária. Notadamente em 2007, por meio da aprovação da Lei federal $\mathrm{n}^{\mathrm{o}}$ 11.481, a regularização fundiária de interesse social passou a ser mais claramente identificada como prioridade.

No âmbito da produção de novas moradias, o governo Lula lançou programas como o Programa de Aceleração do Crescimento (PAC) e o Programa Minha Casa, Minha Vida, que, além do incentivo à promoção de novas moradias e urbanização de assentamentos irregulares, ${ }^{102}$ também incorporou importantes elementos para a dimensão da regularização fundiária de interesse social.

\subsection{Competências federativas da política pública de regularização fundiária urbana de interesse social}

No federalismo brasileiro, caracterizado como cooperativo diante do estabelecimento de um rol considerável de responsabilidades comuns a todos os entes da federação, houve uma nítida opção por estabelecer diretrizes que representavam uma “divisão institucional do trabalho" a ser exercida de modo compartilhado. ${ }^{103}$ Entretanto, diversas são as opções constitucionais acerca dos encargos assumidos por cada ente a depender do tema objeto de exame.

\footnotetext{
${ }^{101}$ Em maio de 2012, o programa havia beneficiado 26.194 (vinte e seis mil cento e noventa e quatro) famílias com registro do título de regularização fundiária. Informação disponível em: $<$ http://www.cidades.gov.br/index.php/o-ministerio/destaques/1541-programa-papel-passado-do-ministeriodas-cidades-ja-beneficiou-26194-familias-com-registro-da-casa-propria>. Acesso em: 26 dez. 2012.

${ }^{102}$ Edésio Fernandes destaca que "é inegável que o quadro institucional federal tem avançado de maneira muito significativa. Com recursos do PAC na implementação de infraestrutura urbana, especialmente através de obras de saneamento ambiental, espera-se que avanços maiores na dimensão da urbanização de muitos assentamentos informais sejam possíveis." (Desafios da regularização fundiária de assentamentos informais consolidados em áreas urbanas. In: Biblioteca Digital Fórum de Direito Urbano e Ambiental - FDUA. Belo Horizonte, ano 9, n. 49, jan/fev. 2010, disponível em: <http://www.editoraforum.com.br/bid/bidConteudo Show.aspx?idConteudo=65211>. Acesso em: 21 fev. 2011).

${ }^{103}$ FARIA, Carlos Aurélio Pimenta de; ROCHA, Carlos Alberto de Vasconcelos. Federalismo, relações intergovernamentais e gestão metropolitana no Brasil. In: CASTRO, Erika; WOJCIECHOWSKI, Maciej John (orgs.). Coleção Limites das Cidades - Inclusão Colaboração e governança urbana: Perspectivas brasileiras. Belo Horizonte: PUC Minas, 2010, p. 110.
} 
Considerando a regularização fundiária urbana de interesse social, na abrangência delineada no Capítulo I da presente dissertação, serão analisados os dispositivos constitucionais que tenham como finalidade a atribuição de competência aos entes federativos em relação aos temas que são direita ou indiretamente aplicáveis ao escopo do trabalho, na medida em que não há no texto constitucional menção expressa à regularização fundiária.

Após a análise dos dispositivos constitucionais, o estudo abordará o detalhamento da competência no âmbito infraconstitucional que, seguindo a diretriz fixada na Constituição Federal, sob pena de inconstitucionalidade, acabam por interferir na dinâmica interfederativa de algum modo, conforme restará demonstrado. Nesse sentido, serão objeto de exame o Estatuto da Cidade, a Lei do Sistema Nacional de Habitação de Interesse Social e a Lei do Programa Minha Casa, Minha Vida.

\subsubsection{Competências constitucionais}

Iniciando a abordagem dos dispositivos constitucionais e já antecipando a existência de certa confusão institucional criada pela própria Constituição Federal, a atribuição de competências é, em regra, apresentada de maneira sistemática e dividida entre as chamadas competências legislativas e competências materiais ou administrativas. Considerando, portanto, o método de abordagem da constituição, optou-se por analisar cada uma dessas competências em separado.

Especificamente acerca da produção de normas, ou da chamada competência legislativa, no art. 24, inciso $\mathrm{I}^{104}$, a Constituição Federal estabelece a competência concorrente da União, dos Estados e do Distrito Federal para legislar sobre direito urbanístico. $^{105}$ Nesses casos, a União estabelece normas gerais que podem ser suplementadas pelos Estados e pelo Distrito Federal, conforme previsto no art. $24, \S 2^{\mathrm{o}^{106}}$. A competência da União em instituir normas gerais acerca da política urbana fica ainda

\footnotetext{
104 “Art. 24. Compete à União, aos Estados e ao Distrito Federal legislar concorrentemente sobre:I - direito tributário, financeiro, penitenciário, econômico e urbanístico;” (CF).

105 Parte-se diretamente para o art. 24, tendo em vista que o art. 22 que trata da competência legislativa privativa da União não apresenta conteúdo diretamente aplicável com o tema aqui desenvolvido.

106 “Art. 24. [...] $\S 2^{\circ}$ - A competência da União para legislar sobre normas gerais não exclui a competência suplementar dos Estados. $\$ 3^{\circ}$ - Inexistindo lei federal sobre normas gerais, os Estados exercerão a competência legislativa plena, para atender a suas peculiaridades." (CF)
} 
ressaltada no art. $182^{107}$ da Constituição Federal que, ao definir a competência municipal para executar a política de desenvolvimento urbano, acaba por destacar a necessidade de fixação de diretrizes gerais por lei, aqui subentendida como lei federal, que foram estabelecidas por meio da aprovação do Estatuto da Cidade.

Aos Estados, além da competência de suplementar, o art. $25, \S 3^{{ }^{108}}$ previu a possibilidade de instituição de regiões metropolitanas, aglomerações e microrregiões, para integrar a organização, o planejamento e a execução de funções públicas de interesse comum. Tal dispositivo, ainda que apresente um conteúdo mais voltado para competência material, não deixa de abranger certa competência legislativa inerente à organização e ao planejamento das funções de interesse comum.

No tocante aos Municípios, a Constituição estabelece no art. 30, incisos I e VIII ${ }^{109}$, a competência para: (i) legislar sobre assuntos de interesse local; e (ii) promover, no que couber, adequado ordenamento territorial, mediante planejamento e controle do uso, do parcelamento e da ocupação do solo urbano que, sem dúvida, compreende a esfera legislativa. Além disso, prevê no art. $182, \S 1^{\mathrm{o}}{ }^{110}$ que o plano diretor, aprovado pela Câmara Municipal, é o instrumento básico da política urbana.

No âmbito da produção de normas relativas ao desenvolvimento urbano, é possível observar que a Constituição identifica a necessidade de existirem normas gerais aplicáveis ao país como um todo e, ao mesmo tempo, normas específicas que considerem as peculiaridades locais. Percebe-se, ainda, que, nessa seara, pouco se conferiu aos Estados, restando a eles praticamente apenas suplementar as normas gerais editadas pela União, as quais, em verdade, só poderão ser concretizadas por normas Municipais.

Em linhas gerais e apenas com o intuito exemplificativo, algumas das normas que acabam por dar cabo à competência legislativa da União acerca do tema são: Lei federal de

\footnotetext{
107 “Art. 182. A política de desenvolvimento urbano, executada pelo Poder Público municipal, conforme diretrizes gerais fixadas em lei, tem por objetivo ordenar o pleno desenvolvimento das funções sociais da cidade e garantir o bem- estar de seus habitantes." (CF)

108 “Art. 25. Os Estados organizam-se e regem-se pelas Constituições e leis que adotarem, observados os princípios desta Constituição. [...] $\S 3^{\circ}$ - Os Estados poderão, mediante lei complementar, instituir regiões metropolitanas, aglomerações urbanas e microrregiões, constituídas por agrupamentos de municípios limítrofes, para integrar a organização, o planejamento e a execução de funções públicas de interesse comum.” (CF)

109 “Art. 30. Compete aos Municípios: I - legislar sobre assuntos de interesse local; [...] VIII - promover, no que couber, adequado ordenamento territorial, mediante planejamento e controle do uso, do parcelamento e da ocupação do solo urbano." (CF)

110 “Art. 182. [...] $\S 1^{\circ}$ - O plano diretor, aprovado pela Câmara Municipal, obrigatório para cidades com mais de vinte mil habitantes, é o instrumento básico da política de desenvolvimento e de expansão urbana." (CF)
} 
Parcelamento do Solo, o Estatuto da Cidade, Lei federal do Programa Minha Casa Minha Vida, o Código Florestal etc. Em relação aos Municípios, cita-se o próprio plano diretor, a lei de zoneamento, o código de obras etc.

Entendendo a regularização fundiária de interesse social como inserida nas diretrizes do desenvolvimento urbano, nas normas de direito urbanístico e como tema de interesse, claramente, local, ${ }^{111}$ a todos os entes é conferida certa responsabilidade em relação a sua formulação: a União é responsável por instituir normas gerais; os Estados são competentes para suplementar as normas gerais naquilo que couber e, ainda, instituir regiões metropolitanas que tenham como finalidade integrar Municípios para a solução conjunta da irregularidade das ocupações; e os Municípios, respeitadas as diretrizes dos demais entes quando não conflitantes com a realidade local, podem legislar sobre os assuntos que sejam de interesse local.

Observa-se que, no âmbito normativo, a estratégia de organização constitucional dos entes federativos em matéria urbanística parece bastante concatenada e harmonizada, tendo a União o papel de disciplinar aspectos gerais aplicáveis ao território nacional, sem deixar de conferir margem de competência aos Municípios para adequar a legislação às especificidades locais, cabendo ao Estado suplementar as normas gerais naquilo que couber.

Ainda assim, em matéria da formulação da política urbana, há uma clara elevação da importância conferida aos Municípios, tendo em vista que o principal instrumento a dar concretude para a política urbana, o Plano Diretor, é de competência estritamente Municipal.

No desempenho da competência material, se por um lado não se observa tal coordenação entre os entes, por outro há também um destaque do Município na execução da política urbana.

De partida, art. 21, inciso $\mathrm{XX}^{112}$, prevê que compete à União instituir diretrizes para o desenvolvimento urbano, incluindo habitação, e o inciso $\mathrm{IX}^{113}$, do mesmo dispositivo, define, também como competência da União, a edição e execução de planos nacionais e

\footnotetext{
${ }^{111}$ Tal assertiva é confirmada no art. 182 da Constituição Federal quando há um reconhecimento do poder público municipal como responsável pelo desenvolvimento urbano.

112 “Art. 21. Compete à União: [...] XX - instituir diretrizes para o desenvolvimento urbano, inclusive habitação, saneamento básico e transportes urbanos;" (CF)

113 “Art. 21. Compete à União: [...] IX - elaborar e executar planos nacionais e regionais de ordenação do território e de desenvolvimento econômico e social;" (CF)
} 
regionais de ordenação do território e de desenvolvimento econômico e social. ${ }^{114} \mathrm{Na}$ sequência, o art. 23, incisos IX e $\mathrm{X}^{115}$, estabelece a competência comum de todos os entes da federação na promoção de programas de construção de moradias e melhoria das condições habitacionais, bem como no combate às causas da pobreza e aos fatores de marginalização, promovendo a integração social dos setores desfavorecidos.

Todos esses temas relacionam-se com a regularização fundiária de interesse social em alguma medida. A construção de moradia, por exemplo, pode tanto se referir à adequação das ocupações às normas de caráter urbanístico como pode representar uma política preventiva de oferta de moradia, que atuará juntamente com a regularização fundiária e seu caráter curativo, como será adiante apontado. A expressão "melhoria das condições habitacionais" pode, também, albergar aspectos como segurança jurídica da posse, habitabilidade e acesso a serviços públicos. No mesmo sentido, a regularização fundiária também pode ser identificada como uma política de combate às causas da pobreza e aos fatores de marginalização, capaz de promover a integração social dos setores desfavorecidos.

Reforçando o papel dos Municípios na execução material, o caput do art. 182 estabelece que a política de desenvolvimento urbano, tendo como objetivo o pleno desenvolvimento das funções sociais da cidade e a garantia do bem-estar de seus habitantes, deve ser executada pelo Poder Público municipal. A Constituição Federal confere, assim, realce aos Municípios.

Cabe destacar que, no âmbito das competências materiais, pouca importância foi conferida aos Estados pela Constituição Federal. Em verdade, sua importância foi equiparada à importância da União, exceto em regiões metropolitanas, aglomerações e microrregiões, com a diferença que a União detém muito mais recursos que o Estado. Conforme já observado, durante o regime militar os Estados desempenhavam um papel central na execução material da política habitacional, período em que Companhias de Habitação Estatuais criadas nas décadas de 1950 e 1960 desenvolveram-se, ou seja, quando da aprovação da Constituição Federal de 1988, existia um aparato institucional

\footnotetext{
${ }^{114}$ Nota-se que, apesar do caput não indicar expressamente que tais hipóteses são consideradas competências materiais, a natureza das obrigação fez com que a doutrina assim o fizesse. (Cf. SILVA, José Afonso da. Curso de Direito Constitucional Positivo. 20. ed. São Paulo: Malheiros, 2001, p. 494.

115 “Art. 23. É competência comum da União, dos Estados, do Distrito Federal e dos Municípios: [...] IX promover programas de construção de moradias e a melhoria das condições habitacionais e de saneamento básico; X - combater as causas da pobreza e os fatores de marginalização, promovendo a integração social dos setores desfavorecidos;" (CF)
} 
para executar a política habitacional no âmbito Estadual que deixou de ter a mesma importância que tinha no âmbito da federação.

Mesmo nos casos de regiões metropolitanas, o debate acerca da competência Estadual e da relativização da competência Municipal, não está equacionado. Isso porque, diante de um contexto político-institucional que equilibra as três esferas de governo, a dificuldade de planejamento e execução de políticas no âmbito metropolitano decorre da relativização da autonomia Municipal, não apenas em face do Estado, mas também em relação aos demais Municípios, aliada à histórica desigualdade intra e inter-regional que gera desequilíbrios, ainda mais quando congregados nas regiões metropolitanas, aglomerações e microrregiões. ${ }^{116}$

A análise da distribuição de competências permite afirmar que a Constituição Federal procurou responsabilizar todos os entes, em alguma medida, na tarefa de regular e executar políticas voltadas à ordenação do espaço, à inclusão social e ao provimento de habitação popular nas cidades, sem, contudo, deixar de destacar o caráter descentralizador da própria Constituição, quando confere ao Município posição de destaque no âmbito da execução e formulação da política de desenvolvimento. ${ }^{117}$

\subsubsection{A relação interfederativa decorrente da legislação federal infraconstitucional}

Realizados os delineamentos constitucionais acerca das competências federativas dos entes, cumpre examinar as normas de competência previstas na legislação infraconstitucional para identificar: (i) os aspectos que contribuem para aclarar as conclusões já exaradas acima; e (ii) os complementos que podem ser extraídos da

\footnotetext{
${ }^{116}$ SOUZA, Celina. Regiões Metropolitanas. In: RIBEIRO, Luiz Cesar de Queiroz. Metrópoles: entre a coesão e a fragmentação, a cooperação e o conflito. Fundação Perseu Abramo/FASE/Observatório das Metrópolis, 2004, p. 92.

117 Destaca-se que movimento no sentido da descentralização e fortalecimento dos Municípios ou dos organismos locais não ocorreu exclusivamente no Brasil, tendo sido uma alternativa adotada em quase toda América Latina. Os problemas decorrentes desse processo são também passíveis de serem encontrados em um contexto mais ampliado, conforme constata Peter M. Ward: "Esta tendencia implica que una responsabilidad creciente de regularización recae sobre las autoridades urbanas, y a su vez plantea otros problemas importantes: la capacidad institucional, el aprendizaje y la diseminación de la mejores práticas, el desarrollo de la capacidad y la responsabilidad fiscales, la continuidad de los programas a través de distintas administraciones, la coordinación e implementación de programas en jurisdicciones metropolitanas [...]" (Foro internacional sobre regularización y mercados de la tierra. In: SMOLKA, Martim O.; MULLAHY, Laura (editores). Perpectivas Urbanas: temas críticos en políticas de suelo en América Latina, Cambridge: Lincoln Institute of Land Policy, 2007, p. 102).
} 
legislação federal ordinária. ${ }^{118}$ Para tanto, foram selecionadas três leis que apresentam interface com o tema e se propõem a tratar das competências: o Estatuto da Cidade, a Lei do Sistema Nacional de Habitação de Interesse Social e a Lei do Programa Minha Casa, Minha Vida, em relação ao capítulo da regularização fundiária.

Partindo do Estatuto da Cidade, o único dispositivo que trata expressamente da competência é o art. $3^{\circ}$, que assim prevê:

Art. $3^{\circ}$ compete à União, entre outras atribuições de interesse da política urbana:

I - legislar sobre normas gerais de direito urbanístico;

II - legislar sobre normas para a cooperação entre a União, os Estados, o Distrito Federal e os Municípios em relação à política urbana, tendo em vista o equilíbrio do desenvolvimento e do bem-estar em âmbito nacional;

III - promover, por iniciativa própria e em conjunto com os Estados, o Distrito Federal e os Municípios, programas de construção de moradias e a melhoria das condições habitacionais e de saneamento básico;

IV - instituir diretrizes para o desenvolvimento urbano, inclusive habitação, saneamento básico e transportes urbanos;

V - elaborar e executar planos nacionais e regionais de ordenação do território e de desenvolvimento econômico e social.

Percebe-se, pela análise do dispositivo, que a lei repetiu exatamente aquilo que vem previsto na própria Constituição, sem conferir qualquer delineamento, destacando tão somente as atribuições da União. Seguindo a mesma lógica, o Estatuto da Cidade releva a importância dos Municípios quando condiciona a eficácia de alguns instrumentos à lei municipal específica ou à previsão no Plano Diretor: (i) art. $5^{\circ}$, que aborda as sanções para imóveis não edificados, subutilizados e não utilizados; (ii) art. $7^{\circ}$, que estabelece regras acerca do IPTU progressivo; (iii) art. 33, sobre as Operações Urbanas Consorciadas; (iv) art. 35, que regula a transferência do direito de construir; etc.

O Estatuto da Cidade de um lado reforça a competência e importância da União, sem deixar de reconhecer o papel central do Município na execução da política urbana. Essa dupla importância não ocorre sem contexto.

O movimento no sentido da descentralização e autonomia dos Municípios na

\footnotetext{
118 Sob pena de afrontar o pacto federativo e, portanto, padecer de inconstitucionalidade, a legislação infraconstitucional não tem autorização para regular a repartição de competências. No entanto, na medida em que a distribuição de competências nem sempre abrange todos os temas de maneira direta ou, ainda, de maneira detalhada, cabe à legislação infraconstitucional detalhar tais competências, desde que respeitados as diretrizes constitucionais.
} 
Constituição de 1988 é consequência da necessária contraposição ao regime centralizado com a qual o regime democrático pretendia romper, bem como do acolhimento das reivindicações dos municipalistas durante a constituinte. Essa descentralização, porém, apesar de ser garantida formalmente, apresenta certas distorções que decorrem, principalmente, da capacidade econômica e institucional dos Municípios.

No âmbito da dependência dos Municípios em relação às transferências correntes e vinculadas, faz-se importante destacar o estudo de Maria Cristina Mac Dowell:

Em seu conjunto, os municípios apresentam um indicador de autonomia
restrita a $33 \%$, o que significa que apenas esse percentual de receita
corrente é gerado por meio da arrecadação de tributos ou outras receitas
próprias. O mesmo pode ser interpretado de outra forma: as transferências
representam $66,2 \%$ do total das receitas correntes em 2004 . [...] E quais as
consequências do retorno das transferências vinculadas? O principal
impacto, sob o ponto de vista do governo local é a redução do poder
discricionário dos governos locais quanto à alocação desses recursos. ${ }^{119}$

Fica, portanto, evidenciada a dependência dos recursos, principalmente do governo federal que os detém em maior quantidade. Desse modo, o fato do Estatuto da Cidade prever apenas a União, denota a intenção de destaque conferido à União para a realização da política urbana.

Seguindo a lógica de outros setores que procuram dar operacionalização às diretrizes constitucionais acerca das competências de modo a organizar as atribuições dos entes federados no âmbito de determinado setor de atuação, como ocorre no caso do Sistema Único de Saúde, estruturado pela Lei Orgânica da Saúde - Lei federal $n^{\circ}$ 8.080/1990 -, a Lei do Sistema Nacional de Habitação de Interesse Social - Lei federal $n^{\text {o }}$ $11.124 / 2005$ - busca fazer o mesmo.

Não obstante o estabelecimento de atribuições para a União, ${ }^{120}$ Estados, Distrito Federal e Municípios, como tentativa de articular as ações com vista ao atingimento de seus objetivos, ${ }^{121}$ o art. 17 da Lei federal $n^{\circ} 11.124 / 2005$ que trata das atribuições dos Estados, Distrito Federal e Municípios menciona apenas o seguinte:

\footnotetext{
${ }^{119}$ Financiamento urbano no Brasil: um olhar sobre as finanças municipais. In: CESARE, Claudia M. de; CUNHA, Eglaísa Micheline Pontes. Programa Nacional de Capacitação das Cidades - Financiamento das cidades: instrumentos fiscais e de política urbana. Brasil: Ministério das Cidades, 2007, p. 36.

${ }^{120}$ Art. 14, art. 15, art. 16 da Lei federal n ${ }^{0} 11.124 / 2005$.

${ }^{121}$ São objetivos: (i) viabilizar para a população de menor renda o acesso à terra urbanizada e à habitação digna e sustentável; (ii) implementar políticas e programas de investimentos e subsídios, promovendo e viabilizando o acesso à habitação voltada à população de menor renda; e (iii) articular, compatibilizar, acompanhar e apoiar a atuação das instituições e órgãos que desempenham funções no setor da habitação.
} 
Os Estados que aderirem ao SNHIS deverão atuar como articuladores das ações do setor habitacional no âmbito do seu território, promovendo a integração dos planos habitacionais dos Municípios aos planos de desenvolvimento regional, coordenando atuações integradas que exijam intervenções intermunicipais, em especial nas áreas complementares à habitação, e dando apoio aos Municípios para a implantação dos seus programas habitacionais e das suas políticas de subsídios.

Assim, a estruturação do Sistema Nacional de Habitação de Interesse Social não estabelece de maneira estruturada e coordenada as ações que devem ser empreendidas por cada ente, mas destaca o papel da União no processo de coordenação e alocação dos recursos.

No tocante especificamente ao tema da regularização fundiária, a Lei que instituiu o Programa Minha Casa, Minha Vida reforça todos os aspectos acima mencionados acerca da distribuição de competências. Desse modo, estabelece, no art. $50^{122}$, a competência comum da União, Estados, Distrito Federal e Municípios para promover a regularização fundiária e ressalta, no art. $49^{123}$, a competência municipal para a execução e adequação da política aos aspectos locais que autoriza o Município a dispor acerca do procedimento de regularização fundiária, respeitadas as diretrizes gerais fixadas nessa lei, no Estatuto da Cidade e no art. $51^{124}$, que garante margem para os Municípios definirem requisitos específicos relacionados ao projeto de regularização fundiária.

Ainda no tocante ao Programa Minha Casa, Minha Vida, importa destacar os aspectos da Lei voltados para a aquisição de novas unidades habitacionais ou requalificação de imóveis urbanos e produção ou reforma de habitações rurais, para famílias com renda mensal de até $\mathrm{R} \$ 4.650,00$ (quatro mil, seiscentos e cinquenta reais).

Isso porque, apesar de não ter a finalidade direta de organizar as atribuições aos entes federados no setor habitacional, a Lei acaba por criar um sistema de relacionamento interfederativo para dar conta da tarefa que se propõe. Assim, em linhas gerais, estabelece que a União é responsável pela disponibilização de recursos ${ }^{125}$, a serem utilizados pelos Estados, Distrito Federal e Municípios, segundo as diretrizes fixadas pela União, por

\footnotetext{
122 “Art. 50. A regularização fundiária poderá ser promovida pela União, pelos Estados, pelo Distrito Federal e pelos Municípios e também por: [...]” (Lei n $\left.{ }^{\circ} 11.977 / 2009\right)$

123 “Art. 49. Observado o disposto nesta Lei e na Lei $\mathrm{n}^{\circ}$ 10.257, de 10 de julho de 2001, o Município poderá dispor sobre o procedimento de regularização fundiária em seu território.” (Lei nº 11.977/2009)

124 “Art. 51. O projeto de regularização fundiária deverá definir, no mínimo, os seguintes elementos: [...] $\S 2^{\circ}$ O Município definirá os requisitos para elaboração do projeto de que trata o caput, no que se refere aos desenhos, ao memorial descritivo e ao cronograma físico de obras e serviços a serem realizados." (Lei $\mathrm{n}^{\mathrm{o}}$ 11.977/2009)

${ }^{125}$ Por meio dos mecanismos indicados no art. $2^{\circ}$ da Lei ${ }^{\circ} 11.977 / 2009$.
} 
exemplo, em relação aos destinatários da política. Os demais entes devem apresentar contrapartidas, como a doação de terrenos localizados em área urbana consolidada para implantação de empreendimentos vinculados ao programa e a implementação de medidas de desoneração tributária, para as construções destinadas à habitação de interesse social.

Nota-se que um impacto prático do sistema criado pelo Programa Minha Casa, Minha Vida, que atinge indiretamente o acordo interfederativo, foi no sentido de que muitos Municípios e Estados deixaram de dar andamento aos seus projetos habitacionais para aderir ao programa de governo federal.

Ainda que não se vislumbre nenhuma inconstitucionalidade ou ilegalidade nessa sistemática, importa tão somente pontuar que apesar do destaque constitucional dado aos Municípios, a capacidade de gestão e de financiamento da União conferem a ela uma posição que passa a ser exercida muitas vezes como de forte liderança, induzindo, viabilizando e até definindo e executando grandes projetos de regularização fundiária, a exemplo de outros programas: Programa Habitar Brasil - Banco Interamericano de Desenvolvimento, Programa Nacional de Regularização Fundiária e o Programa de Aceleração do Crescimento (PAC). ${ }^{126}$

\subsection{Síntese conclusiva do capítulo}

Diante dos aspectos apresentados acerca do exame da relação entre o Estado e a regularização fundiária urbana de interesse social centrados no histórico e nas competências, é possível destacar algumas considerações.

Um primeiro importante diagnóstico refere-se à ausência de articulação institucional, entre os entes federativos e dentro da própria esfera federal, para tratar a problemática habitacional após o fím do regime militar e a extinção do BNH. O resultado, na esfera federal, foi a desorganização institucional, observada por meio da falta de integração dos agentes financeiros estatais (Banco Central, Banco do Brasil, Caixa Econômica Federal) e conflitos entre os órgãos do próprio Ministério das Cidades.

No âmbito da produção de novas moradias, problemas foram, ainda, encontrados em relação às questões que envolvem o financiamento dos programas propostos para

\footnotetext{
${ }^{126}$ BALBIM, op. cit., p. 294.
} 
produção e venda de unidades habitacionais para dar conta do déficit de oferta de habitação, tendo em vista a dificuldade de estruturação de um modelo autossustentável que fosse capaz de dar retorno ao investimento realizado, quando o destinatário é a população de baixa renda.

No tocante à regularização fundiária de interesse social, ainda que tenha havido iniciativas nos Municípios desde a década de 1980 (oitenta) e, do ponto de vista normativo, importantes marcos surgiram com a Constituição Federal de 1988 e o Estatuto da Cidade, a destinação de recursos federais voltados especificamente para políticas de regularização fundiária de interesse social teve início apenas 2003 com o Programa Nacional de Regularização Fundiária Sustentável, que, apesar da concepção ampla do instituto, teve dificuldades práticas de implementar o programa, tendo um foco inicial na legalização da posse. Ressalta-se ainda que foi estabelecido muito após a década de 1970, período em que a maior parte da população brasileira passou a viver nas cidades.

Sendo assim, os programas federais foram, em grande medida, marcados: (i) pela ausência de mecanismos voltados para a regularização fundiária de interesse social, sendo recente a incorporação dessa diretriz na política habitacional; (ii) por políticas de provimento de habitação popular que não davam conta de ofertar o montante de unidades habitacionais necessário para sanar a demanda por moradia popular; e (iii) pela pouca articulação entre ambas as alternativas, regularização fundiária de interesse social e provimento de moradia popular.

A Constituição Federal confere atribuições legislativas e materiais e prevê atribuições a todos os entes, em alguma medida, no tocante aos temas que se relacionam com a regularização fundiária urbana de interesse social, sem, contudo, deixar de reconhecer e destacar a importância do Município no campo da execução e formulação da política de desenvolvimento urbano.

No âmbito da legislação infraconstitucional, duas são as conclusões possíveis: (i) não há uma preocupação de estabelecer uma sistemática que dê operacionalização às competências materiais comuns; e (ii) a União acaba tendo um papel que se sobrepõe ao dos Municípios, ainda que a Constituição Federal tenha conferido destaque ao poder público municipal. 


\section{CAPÍTULO III \\ INSTRUMENTOS PARA A REGULARIZAÇÃO FUNDIÁRIA URBANA DE INTERESSE SOCIAL}

Diante das considerações apresentadas acerca do conceito de regularização fundiária urbana de interesse social, definida como um processo que congrega ações destinadas a legalizar o exercício da posse e, ao mesmo tempo, implementar melhorias urbanísticas que abranjam desde a estrutura física das moradias até a infraestrutura de serviços públicos no local da ocupação, optou-se por separar a análise dos instrumentos jurídicos de acordo com sua destinação.

A primeira parte destinar-se-á à abordagem dos instrumentos jurídicos aptos a legalizar a situação dominial das áreas ocupadas irregularmente tanto em locais públicos quanto em locais privados, passando na sequência para análise dos instrumentos que têm um viés voltado para a regularização urbanística e, em seguida, daqueles que têm um caráter misto, abrangendo ambas as características.

O capítulo cuidará, ainda, da análise da regularização fundiária urbana de interesse social em Áreas de Preservação Permanente, diante das peculiaridades do local e das recentes previsões legais acerca do tema.

Antes, porém, de dar início à análise, cumpre esclarecer o propósito do estudo que se pretende realizar. Isso porque não se trata de analisar exaustivamente cada um dos instrumentos, mas apenas de apresentá-los em seus aspectos legais, com o intuito de contribuir para a compreensão dos instrumentos ou das dificuldades que envolvem sua utilização quando inseridos em processos de regularização fundiária urbana de interesse social.

\subsection{Instrumentos para a regularização dominial das áreas}

A análise acerca dos instrumentos jurídicos voltados para a regularização dominial pode ser dividida em dois grupos. De um lado encontram-se os mecanismos que atuam no sentido de formalizar o exercício da posse, ou do chamado domínio útil, associado à 
transferência de direitos reais e, de outro, destacam-se os instrumentos que têm como característica a transferência da propriedade do bem, ou sua aquisição primária, à população que ocupa área irregularmente.

Em projetos de regularização fundiária urbana de interesse social, observa-se a prevalência da formalização da posse, por meio do reconhecimento de direitos reais, em detrimento da transferência da propriedade, principalmente quando diante de áreas públicas.

Essa tendência pode ser identificada na análise dos novos mecanismos de regularização fundiária inaugurados pela Lei $n^{0}$ 11.977/2009, Programa Minha Casa, Minha Vida: (i) demarcação urbanística e (ii) legitimação da posse. A abordagem mais detalhada de ambos será empreendida adiante, mas é possível por ora mencionar que se trata de instrumentos destinados ao reconhecimento da posse, ainda que ela venha a ser convertida em propriedade no caso de imóvel privado.

Esse diagnóstico encontra-se em harmonia, tanto com o direito à moradia quanto com o princípio da função social da propriedade, já que não é apenas a propriedade que dá concretude ao direito à moradia ou ao princípio da função social. ${ }^{127}$

No caso da moradia, adotando o parâmetro já indicado anteriormente, sua consolidação ocorre por meio da garantia dos seguintes elementos: segurança jurídica da posse, habitabilidade, disponibilidade de serviços e infraestrutura, custo acessível da moradia, acessibilidade, localização e adequação cultural. Na medida em que a segurança jurídica pode ser atingida por meio do exercício da posse, a propriedade não é elemento essencial para a concretização do direito à moradia pelo ocupante do lote. Por meio da regularização fundiária urbana de interesse social não se trata, portanto, de garantir que todos tenham a propriedade do bem em que exercem a moradia, mas sim do dever de garantir que todos possam exercer seu direito à moradia de maneira digna, segura e adequada do ponto de vista urbanístico.

A função social da propriedade, por sua vez, encontra-se intimamente relacionado ao uso que se dá à propriedade. Trata-se de elemento que acaba por condicionar a propriedade em relação a sua função para a coletividade. Importa, pouco, portanto, o proprietário do bem, mas sim se há o cumprimento de sua função social, sendo relevante saber se o bem está em uso e se tal uso encontra-se albergado pelo ordenamento jurídico.

\footnotetext{
${ }^{127}$ Indo além, Patrícia Menezes de Cardoso afirma que "para transformar a estrutura fundiária brasileira, coibindo a concentração e a exclusão é necessário superar o paradigma da propriedade plena, pois a gestão do uso da terra não depende da transferência de domínio (desapropriação, doação).” (op. cit., p. 147).
} 
Marques Neto, ao discorrer acerca da relevância da função e seu impacto na identificação do regime jurídico a que o bem está submetido chega à seguinte conclusão:

De mais a mais, a função social da propriedade - e a relativização do caráter absoluto da propriedade que ela acarreta - põe cada vez mais frequente a existência de usos (aplicações) de bens privados que se aproximam muito do direito público. [...] Equivale dizer então que hoje o regime jurídico a que se submete um bem é diretamente relacionado a sua função para a coletividade, tornando menos relevante a pessoa titular do direito de propriedade do bem. ${ }^{128}$

Na hipótese da área ser pública, surge uma razão ainda mais relevante para tal prevalência. A transferência de direitos reais sem que haja a transferência da propriedade, permite que a Administração Pública contratualize as condições de uso, fruição e disposição do bem, podendo estabelecer encargos enquanto durar a cessão. Desta feita, o bem cedido permanece inserido em um contexto de gestão pública para o atendimento das necessidades coletivas e da implementação de políticas públicas, evitando que haja desvio de finalidade após o esforço empreendido no projeto de regularização fundiária que deu fundamento ao título.

Realizados tais esclarecimentos, passamos a analisar os instrumentos separados nesta pesquisa de acordo com o regime jurídico aplicável à área objeto da implementação da regularização fundiária urbana de interesse social.

\subsection{1 Áreas públicas: a afetação de bens públicos para projetos de regularização fundiária urbana de interesse social}

No tocante aos bens de domínio público, um aspecto que prescinde a análise dos mecanismos jurídicos aptos a serem instrumentalizados pela Administração Pública em processos de regularização fundiária urbana de interesse social refere-se ao instituto da afetação, tendo em vista sua observância prévia à utilização dos instrumentos jurídicos a seguir abordados.

O termo afetação representa a consagração de um bem público a uma dada função cometida ao Estado, em outras palavras, a demarcação de uma específica destinação, não necessariamente já em uso. Decorre, assim, do princípio da função, já que todos os

${ }^{128}$ MARQUES NETO, op. cit., 2009, p. 392. 
recursos (materiais, humanos e financeiros) do Estado só tem razão de ser se prestantes ao atendimento de necessidades coletivas. ${ }^{129}$

Essa abordagem recebe relevo neste tópico, porque, em grande medida, a afetação expressa do bem público ocupado por população de baixa renda se encontra em descompasso com tal ocupação, sendo de suma importância, assim, analisar o impacto de tal desacerto no reconhecimento do direito à permanência da população no local. Acerca do tema, quatro são as situações a que, na hipótese de ser utilizado em processos de regularização fundiária urbana de interesse social.

No caso do bem encontrar-se ocupado por população de baixa renda, duas são as possibilidades no tocante à afetação: (i) ou há coincidência entre a afetação expressa (formal) do bem e sua utilização fática (material), estando abrangida em tal afetação a possibilidade de realização de processos de regularização fundiária de interesse social; (ii) ou há um descompasso entre a afetação expressa do bem e sua utilização de fato.

$\mathrm{Na}$ hipótese de não haver ocupação prévia do bem por população de baixa renda, mas existir a intenção da Administração Pública em destinar tal bem público a projetos de regularização fundiária de interesse social, as circunstâncias são praticamente as mesmas: (iii) pode o bem ser afetado expressamente a uma finalidade condizente com tal intenção ou (iv) ter o bem afetação expressa distinta, que demandará uma alteração na afetação para dar concretude à mencionada intenção.

A primeira (i) e a terceira (iii) hipóteses apresentam-se como as mais simples. Nesses casos, há algum tipo de afetação expressa que já estabelece a vinculação do bem a uma destinação que abrange projetos de regularização fundiária de interesse social, bastando utilizar algum dos instrumentos abaixo descritos para, no primeiro caso, garantir a segurança jurídica, aos que ali exercem o domínio útil, e a realização de melhorias urbanísticas no local ou; no segundo caso, integrar o bem já afetado a projetos de regularização fundiária de interesse social, por exemplo, utilizando o bem para prover habitação a moradores que acabaram sendo realocados em decorrência de processos de regularização fundiária de interesse social realizados em outras áreas.

Destaca-se que a afetação expressa ${ }^{130}$ pressupõe a edição e um ato, legal ou

\footnotetext{
${ }^{129}$ MARQUES NETO, op. cit., p. 283.

130 Nesse caso, além de expressa, a afetação pode ser classificada também como imprópria, já que corresponde à destinação do bem a uma finalidade de interesse público, sem que haja uma predisposição do
} 
infralegal, destinando o bem a uma determinada finalidade. Tomando o exemplo aqui mencionado, seriam atos de afetação expressa: a Lei que aprova o Plano Diretor do Município estabelecendo regiões da cidade compostas por áreas públicas como Zonas Especiais de Interesse Social, voltadas para a realização de projetos habitação de interesse social; o decreto de desapropriação por interesse social, que preveja no ato expropriatório a utilização do bem para projetos de regularização fundiária de interesse social; ou, ainda, a Lei federal $n^{0} 11.952 / 2009$, que destina terras situadas em áreas da União, no âmbito da Amazônia Legal, que tenham as características expostas no art. $3^{\circ},{ }^{131}$ para programas de regularização fundiária a serem empreendidos pelos Municípios.

O segundo (ii) e o quarto (iv) casos, apesar de semelhantes, dependem de providências para alterar a afetação expressa do bem, por meio da desafetação e posterior afetação a outra finalidade. Na situação (ii), em que já existe ocupação por população de baixa renda, há uma realidade fática de uso do bem que permite pontuar uma diferença acerca de sua afetação, tendo em vista a possibilidade de considerar afetações tácitas de bens públicos a uma determinada finalidade, como ensina Marques Neto:

A afetação pode ser expressa (formal) ou tácita (material ou fática). [...] A segunda prescinde de um ato formal, manifestando-se por um fato, uma circunstância concreta de emprego do bem a uma dada finalidade, o que se coaduna, como antes dissemos, com a referência constitucional a bens públicos pela simples pertença (artigo 20, I, CF). ${ }^{132}$

Assevera-se com isso que o uso dado pode condicionar a destinação do bem. Ainda que não seja ela expressa, seria possível afirmar que o bem se encontra afetado àquela finalidade que decorre do uso ao qual o bem está servindo. Disso, surgem algumas questões não menos importantes: haveria limitação à afetação tácita? Na hipótese de inexistir uma afetação expressa, a afetação tácita deve preponderar? E se houver uma afetação expressa que indique para uma utilização diversa daquela empreendida materialmente, qual afetação deve prevalecer: a expressa ou a tácita?

bem a um uso específico de interesse geral (uso comum) ou utilidade de suporte a uma atividade de interesse geral (uso especial). (MARQUES NETO, op. cit. 2009, p. 284).

131 “Art. $3^{\circ}$ São passíveis de regularização fundiária nos termos desta Lei as ocupações incidentes em terras: I - discriminadas, arrecadadas e registradas em nome da União com base no art. $1^{\circ}$ do Decreto-Lei $n^{\circ} 1.164$, de $1^{\circ}$ de abril de 1971; II - abrangidas pelas exceções dispostas no parágrafo único do art. $1^{\circ}$ do Decreto-Lei $\mathrm{n}^{\circ} 2.375$, de 24 de novembro de 1987; III - remanescentes de núcleos de colonização ou de projetos de reforma agrária que tiverem perdido a vocação agrícola e se destinem à utilização urbana; IV - devolutas localizadas em faixa de fronteira; ou V - registradas em nome do Instituto Nacional de Colonização e Reforma Agrária - Incra, ou por ele administradas." (Lei federal n ${ }^{\circ} 11.952 / 2009$ )

${ }^{132}$ MARQUES NETO, op. cit. 2009, p 283. 
Partilhamos do entendimento de Marques Neto, no sentido de que a afetação tácita não pode ser encarada como a regra geral de destinação de bens públicos, já que:

[...] a afetação formal e expressa é a que mais se coaduna com os cânones da publicidade, da legalidade (ampla, como vimos) e mesmo da eficiência, haja vista que a edição de um ato de afetação torna tal consagração do bem presumidamente mais refletida, sopesada, favorecendo a otimização de sua gestão. ${ }^{133}$

Uma primeira conclusão seria no sentido de haver limites à afetação tácita, já que ela retira do poder público a possibilidade de previamente arbitrar acerca da destinação mais conveniente para o atingimento das finalidades coletivas. Entretanto, considerando a existência de espaço para que a afetação tácita ocorra, importa buscar parâmetros para justificar as situações fáticas que acabam condicionando a destinação do bem público.

Tentando responder às questões formuladas, cumpre primeiramente abordar o tema da inexistência de uma afetação expressa, em outras palavras, a ausência de um ato formal que previamente estabeleça determinada finalidade para o bem. Ainda assim, não nos parece correto asseverar que a afetação tácita prevaleça indistintamente. Essa prevalência é possível apenas quando a utilização material não vá de encontro com necessidades coletivas ou com a implementação de políticas públicas. Nota-se que por esse critério não importa quem utiliza tal bem, mas apenas se essa utilização é condizente com o interesse público e irá contribuir para a satisfação de necessidades coletivas.

No mesmo sentido, também não nos parece correto afirmar que a afetação expressa sempre prevaleça sobre a tácita, já que, por alguma razão, a utilização do bem condizente com a afetação expressa não ocorreu, dando margem para que outro uso emergisse. Em outras palavras, houve uma desafetação tácita que poderia fundamentar uma posterior afetação tácita. Isso pode ter ocorrido por inúmeras razões que acabam por indicar a má gestão do patrimônio público. Por outro lado, também não nos parece coerente afirmar que apenas a má gestão justificaria a alteração da destinação expressa para a destinação tácita.

Em todos os casos indicados, a solução teria que abranger a análise da situação concreta do bem público em questão. Não seria possível a priori afirmar que determinada circunstância fática prevaleça sobre a destinação formal e vice versa. A decisão acerca da prevalência de uma afetação sobre a outra haveria de considerar alguns critérios de ponderação entre o uso expressamente determinado e o uso efetivamente empreendido.

\footnotetext{
${ }^{133}$ MARQUES NETO, op. cit., 2009, p 284.
} 
Para tanto, propõe-se a aplicação dos seguintes critérios de ponderação a serem adotados pela Administração Pública: (i) sopesamento entre a destinação efetiva do bem e sua utilidade para o cumprimento de políticas públicas; (ii) a ponderação acerca dos custos (econômicos, políticos e sociais) envolvidos na alteração do uso efetivo para o uso expressamente previsto; (iii) a identificação da parcela da população beneficiada.

Ressalta-se que tais critérios devem ser utilizados nas situações em que a população não preencha os requisitos para a Concessão Especial de Uso para Fins de Moradia. Isso porque, no caso da Concessão Especial de Uso para Fins de Moradia, o ordenamento jurídico reconhece expressamente que a utilização de bens públicos para fins de moradia pode, cumprindo os requisitos abaixo delineados, gerar direito da população à permanência no local ou à garantia de seu direito à moradia em outro local quando a permanência não for possível. Nesse caso, fica evidenciado que, independentemente da afetação do bem, é o seu uso que dá margem ao surgimento do direito à regularização fundiária, sendo inaplicável o critério de sopesamento acima exposto.

Diante do apresentado, a afetação prévia de determinado bem público para fins de regularização fundiária urbana de interesse social evita questionamentos acerca da possibilidade de o bem ter essa destinação, ainda que a ausência de prévia afetação expressa não represente automática impossibilidade de a afetação ser alterada.

\subsubsection{Concessão de direito real de uso}

Em linhas gerais, a Concessão de Direito Real de Uso (CDRU), regulada pelo Decreto-Lei $\mathrm{n}^{0}$ 271/1967, caracteriza-se por ser um contrato que tem como objetivo a concessão de direitos reais sobre bens públicos a particulares, ${ }^{134}$ com a condição de que sejam destinados aos fins buscados pela lei, dentre os quais se destacam: a regularização fundiária de interesse social, urbanização, industrialização, edificação, cultivo da terra, aproveitamento sustentável das várzeas, preservação das comunidades tradicionais e seus meios de subsistência ou outras modalidades de interesse social em áreas urbanas.

No art. $7^{\circ}$ e seus parágrafos do Decreto-Lei $n^{\circ}$ 271/1967, há a identificação das principais características do instituto podendo ser: (i) gratuita ou onerosa; (ii) por tempo certo

\footnotetext{
${ }^{134} \mathrm{O}$ art. $7^{\circ}$ do Decreto-Lei $\mathrm{n}^{\mathrm{o}}$ 271/1967 prevê a aplicabilidade da CDRU também a bens privados.
} 
ou ilimitado; (iii) resolúvel, na hipótese do concessionário dar ao imóvel destinação diversa da estabelecida no contrato ou termo ou, ainda, descumprir cláusula resolutória do ajuste; e (iv) contratada por instrumento público ou particular, ou por simples termo administrativo.

Em relação ao conteúdo econômico do ajuste, entende-se que é possível haver razões que justifiquem a gratuidade em situações concretas, nas quais a população beneficiária da CDRU não detenha renda suficiente para dar conta de encargos financeiros, entretanto tal alternativa não deve ser a única adotada pela Administração Pública quando da aplicabilidade do instituto.

Isso ocorre por duas razões centrais. A primeira relaciona-se à diversidade de ocupações irregulares nas cidades que culmina em diferentes capacidades econômicas, sendo possível encontrar comunidades que tenham condições de arcar com encargos, ainda que pequenos. A segunda envolve, conforme já mencionado, a necessidade de realização de intervenções urbanísticas no sentido de garantir melhorias nas condições de habitabilidade. Tais intervenções têm custo e a onerosidade da CDRU poderia contribuir para esse custeio. É evidente que a definição dos valores não pode desvirtuar a finalidade do instituto e, no âmbito de projetos de regularização fundiária urbana de interesse social, deve sempre estar voltada para a permanência da população de baixa renda no local.

Em relação ao tema do limite temporal da CDRU, partilhamos do entendimento de que não seria compatível com o regime de contratos adotá-la por tempo ilimitado. Além do próprio Decreto-Lei $n^{0} 271 / 1967$ ser contraditório quando estabelece no caput do art. $7^{\circ}$ a possibilidade da concessão ser realizada por tempo indeterminado e em seu $\S 3^{\circ}$ a resolução antes do termo, assumindo a existência de um fim; a ausência de prazo iria de encontro ao previsto no art. $57, \S 3^{\circ}$ da Lei $n^{\circ} 8.666 / 1993$ que veda a realização de contrato por prazo indeterminado. $^{135}$

A característica da resolubilidade da CDRU reforça o caráter contratual e, portanto, sinalagmático do mecanismo, já que impõe a necessidade do concessionário permanecer vinculado às razões que justificaram a concessão. Destaca-se que a vinculação permanece ainda que haja transferência por ato inter vivos, ou por sucessão, nos termos do $\S 4^{\circ}$ do art. $7^{\circ}$ do Decreto-Lei ${ }^{\circ}$ 271/1967.

Apesar de as possibilidades de formalização envolverem a contratação por instrumento público ou particular, ou por simples termo administrativo, a CDRU não deixa

${ }^{135}$ MARQUES NETO, op. cit. 2009, p 353-359. 
de ser um contrato.

A necessidade de prévia aprovação legislativa para a utilização do instituto é outro aspecto que merece detalhamento. Isso decorre porque a própria Constituição Federal, ao tratar do tema da autorização legislativa em casos de concessão, delimitou apenas uma situação em que a autorização legislativa seria imprescindível: nas hipóteses de concessão de terras públicas da União com área superior a dois mil e quinhentos hectares (art. 49, XVII e art. $188, \S 1^{\circ}$, ambos da CF). Sendo assim, exigir autorização legislativa para qualquer CDRU acabaria por ampliar a ingerência do Legislativo na esfera do Executivo, responsável pela gestão do patrimônio público, padecendo o dispositivo de inconstitucionalidade. Entretanto, não apenas a Lei $n^{\circ}$ 8.666/1993 assim previu em seu art. 17, inciso I, alínea "f"136, como também o fizeram diversas Constituições Estatuais ${ }^{137}$ e Leis Orgânicas dos Municípios ${ }^{138}$. Diante da ausência de questionamento acerca dessa inconstitucionalidade, permanece aconselhável a edição de autorização legislativa para a CDRU.

Cumpre ainda esclarecer a abrangência dessa autorização legislativa, na medida em que duas podem ser as interpretações. A primeira seria que cada CDRU a ser contratada pela Administração Pública deveria ter uma autorização legislativa específica. Interpretação diametralmente oposta seria a de que bastaria, para o cumprimento da exigência, uma lei geral que regulasse a contratação da CDRU pelo ente federativo. Apesar de não parecer ser esta última a intenção do legislador, não nos parece adequado sequer exigir tal autorização legislativa para além do que determina a Constituição Federal, sendo mais adequada a filiação à última corrente, tendo em vista reduzir a ingerência do Legislativo, por um lado, e agilizar a gestão patrimonial pelo Executivo, por outro.

\footnotetext{
136 “Art. 17. A alienação de bens da Administração Pública, subordinada à existência de interesse público devidamente justificado, será precedida de avaliação e obedecerá às seguintes normas: I - quando imóveis, dependerá de autorização legislativa para órgãos da administração direta e entidades autárquicas e fundacionais, e, para todos, inclusive as entidades paraestatais, dependerá de avaliação prévia e de licitação na modalidade de concorrência, dispensada esta nos seguintes casos: [...] f) alienação gratuita ou onerosa, aforamento, concessão de direito real de uso, locação ou permissão de uso de bens imóveis residenciais construídos, destinados ou efetivamente utilizados no âmbito de programas habitacionais ou de regularização fundiária de interesse social desenvolvidos por órgãos ou entidades da administração pública;" (Lei n $\left.{ }^{\circ} 8.666 / 1993\right)$ (grifo nosso).

${ }^{137}$ A título exemplificativo, é possível mencionar: art.19, inciso V da Constituição Estadual de São Paulo; art. 15, inciso IV da Constituição Estadual de Pernambuco; art. 62, inciso VI da Constituição Estadual do Mato Grosso do Sul; art. 61, inciso XXXIV da Constituição Estadual de Minas Gerais.

${ }^{138}$ Exemplificando, menciona-se: art. 13, inciso VIII da Leio Orgânica do Município de São Paulo; art. 234 da Lei Orgânica do Município do Rio de Janeiro, nos casos de CDRU para implantação de indústrias, formação de distritos industriais ou implantação de pólos de desenvolvimento econômico e tecnológico; art. $82, \S 1^{\circ}$, inciso VII da Lei Orgânica de Porto Alegre.
} 
No tocante à necessidade de realização de licitação, cumpre apenas mencionar que a Lei n ${ }^{0}$ 8.666/1993 no mesmo art. 17, inciso I, alínea "f", referido acima, prevê a dispensa de licitação nas hipóteses da CDRU ser utilizada para programas habitacionais ou de regularização fundiária de interesse social.

O Estatuto da Cidade trouxe, ainda, alguns aspectos que completam a presente análise. Trata-se da possibilidade da CDRU ser contratada coletivamente quando inserida em programas e projetos habitacionais de interesse social foi prevista no art. $4^{\circ}, \S 2^{\circ}$ da Lei $\mathrm{n}^{\mathrm{o}} 10.257 / 2001$. Nesses casos, houve ainda a preocupação de reforçar o caráter de escritura pública do instituto e sua aceitação obrigatória como garantia em contratos de financiamentos habitacionais (art. 48, incisos I e II da Lei n ${ }^{0} 10.257 / 2001$ ).

\subsubsection{Concessão de uso especial para fins de moradia}

A Concessão de Uso Especial para Fins de Moradia (CUEFM) em muito se assemelha à CDRU, já que ambas são consideradas contratos que transferem, individual ou coletivamente, direitos reais a serem exercidos pelo concessionário, desde que cumpridos determinados encargos e mantida a finalidade que deu ensejo à concessão, podendo ser transferidas por ato inter vivos ou causa mortis. ${ }^{139}$

Algumas peculiaridades, no entanto, tornam a CUEFM um mecanismo bastante singular. A primeira relaciona-se com a especificidade da concessão de uso ser atribuída ao concessionário a partir da configuração de um direito oponível do possuidor que, mesmo diante de imóveis públicos, já vinha prevista no art. $183, \S 1^{\circ}$ da Constituição Federal que dispõe:

Art. 183. Aquele que possuir como sua área urbana de até duzentos e cinquenta metros quadrados, por cinco anos, ininterruptamente e sem oposição, utilizando-a para sua moradia ou de sua família, adquirir-lhe-á o domínio, desde que não seja proprietário de outro imóvel urbano ou rural.

$\S 1^{\circ} \mathrm{O}$ título de domínio e a concessão de uso serão conferidos ao homem ou à mulher, ou a ambos, independentemente do estado civil. (grifo nosso)

Em verdade, a aplicabilidade do dispositivo constitucional aos imóveis públicos acaba por decorrer de um esforço interpretativo, já que a redação do caput do mencionado

${ }^{139}$ Art. $7^{\circ}$ da MP 2.220/2001. 
dispositivo constitucional, ao fazer expressa menção à "aquisição do domínio", aparenta referir-se tão somente à usucapião, inaplicável aos imóveis públicos (art. 183, $\S 3^{\circ}$ da $\mathrm{CF}$ ). No entanto, como há expressa referência à concessão de uso no $\S 1^{\circ}$ do art. 183 da $\mathrm{CF}$, é possível concluir que duas são as hipóteses previstas pelo constituinte em relação ao dispositivo constitucional, conforme ressalta Maria Sylvia Zanella Di Pietro:

a) em relação a imóveis privados aplica-se a usucapião previsto no caput,
com a outorga do título de domínio, já que o dispositivo prevê
expressamente a aquisição do domínio como direito do possuidor que
preencher os requisitos legais; nem seria possível a outorga de título de
concessão de uso para transferência do domínio uma vez que, nesse tipo
de ato, o que se transfere é tão somente o direito de uso;
b) em relação aos imóveis públicos aplica-se a concessão de uso, com a
outorga do respectivo título de concessão de uso previsto no mesmo $\$ 1^{\circ}$,
já que o $§ 3^{\circ}$ expressamente proíbe o usucapião de imóveis públicos. ${ }^{140}$

A tentativa inicial de aprovação do instituto da CUEFM, a regular referido dispositivo constitucional, ocorreu por meio dos artigos 15 a 20 do Projeto de Lei do Estatuto da Cidade. Porém, tais dispositivos foram vetados pelo Presidente da República por três imprecisões consideradas contrárias ao interesse público: (i) ausência de ressalva ao direito à CUEFM em situações com imóveis públicos afetados ao uso comum do povo, dentre outros; (ii) ausência de data-limite para a aquisição do direito à CUEFM, tornando-o perpétuo e retirando do instituto sua característica de atuar no passivo existente à época; e (iii) necessidade de especificação de prazo para que a Administração Pública processe os pedidos de CUEFM.

Tais aspectos foram adequados e logo após dois meses da aprovação do Estatuto da Cidade, foi editada a Medida Provisória $n^{0}$ 2.220/2001 tratando da CUEFM. Ampliando em certa medida o já previsto na Constituição Federal, os artigos $1^{\circ}$ e $2^{\circ}$ da MP 2.220/2001 dispuseram acerca de duas situações que dão ensejo ao surgimento do direito à CUEFM em relação a imóvel público, situado em área urbana, objeto de posse: (i) individualmente, na hipótese do concessionário possuir como seu para sua moradia e de sua família, por cinco anos, ininterruptamente e sem oposição, até duzentos e cinquenta metros quadrados de área; (ii) coletivamente, nos casos de ocupação formada por população de baixa renda para sua moradia, onde não for possível identificar os terrenos ocupados por possuidor, e que, por cinco anos, ininterruptamente e sem oposição, esteja situada em imóvel com

\footnotetext{
${ }^{140}$ DI PIETRO, Concessão de Uso Especial para Fins de Moradia (Medida Provisória $\mathrm{n}^{\mathrm{0}}$ 2.220, de 4.9.2001). DALLARI, Adilson Abreu; FERRAZ, Sérgio (coord.). In: Estatuto da Cidade: Comentários à Lei Federal $n^{o}$ 10.257/2001. 2. ed. São Paulo: Malheiros, 2003, p. 156.
} 
dimensões superiores a duzentos e cinquenta metros quadrados.

Em ambas as situações os cinco anos de exercício ininterruptos e sem oposição devem ser contatos até 30 de junho de 2001, ou seja, atuam no sentido de consolidar situações anteriores à aprovação da MP 2.220/2001. ${ }^{141}$ Além disso, a CUEFM apenas pode ser concedida a possuidores que não sejam proprietários ou concessionários, a qualquer título, de outro imóvel urbano ou rural, sempre de forma gratuita ao homem ou à mulher ou a ambos, independentemente do estado civil (art. $1^{\circ}, \S 1^{\circ}$ da MP 2.220/2001) e, ainda, de modo perpétuo, desde que seja mantida destinação do bem à moradia e o concessionário não adquira a propriedade ou concessão de outro imóvel urbano ou rural (art. $8^{\circ}$, incisos I e II da MP 2.220/2001).

Nas hipóteses em que o direito é exercido de maneira coletiva duas peculiaridades podem ser destacadas. A primeira refere-se ao importante avanço da legislação, que se deu em consonância com o já previsto no Estatuto da Cidade em relação à usucapião especial urbana coletiva, no sentido de possibilitar a somatória das posses do possuidor e seu antecessor (art. $2^{\circ}, \S 1^{\circ}$ da MP 2.220/2001) para comprovação do tempo a ser considerado para o direito à CUEFM. Explica Saule Júnior que "esta norma é fundamental, em razão da rotatividade existente nas favelas, onde o objetivo é assegurar a moradia para a pessoa que estiver na posse do imóvel." 142

A segunda relaciona-se com a atribuição de igual fração ideal de terreno a cada possuidor, independentemente da dimensão do terreno que cada um ocupe, salvo acordo entre os possuidores estabelecendo frações ideais diferenciadas (art. $2^{\circ}, \S 2^{\circ}$ da MP 2.220/2001).

Importa relevar que nas circunstâncias de a ocupação estar inserida em local que venha a oferecer risco à vida ou à saúde dos ocupantes o art. $4^{\circ}$ da MP 2.220/2001 estabelece a obrigatoriedade do Poder Público garantir ao possuidor o exercício do direito à CUEFM, individual ou coletiva, em outro local. Por sua vez, o art. $5^{\circ}$ da MP 2.220/2001 prevê a faculdade do Poder Público assegurar o exercício do mesmo direito em outro local quando a ocupação está situada em imóvel: (i) de uso comum do povo; (ii) destinado a projeto de urbanização; (iii) de interesse da defesa nacional, da preservação ambiental e da proteção dos ecossistemas naturais; (iv) reservado à construção de represas e obras

\footnotetext{
${ }^{141}$ Nesse ponto, é possível identificar certa restrição ao direito constitucionalmente garantido pelo art. 183, tendo em vista que a Constituição Federal não limita a garantia do direito a situações configuradas antes de uma determinada data.

${ }^{142}$ SAULE JUNIOR, op.cit. 2004, p. 391.
} 
congêneres; ou (v) situado em via de comunicação.

Aspecto central, que diferencia a presente CUEFM das demais concessões de uso e que decorre do próprio dispositivo constitucional que fundamenta o instituto, refere-se ao fato de não se apresentar enquanto ato discricionário da Administração Pública. Trata-se de ato vinculado a ser conferido ao possuidor que cumpre os requisitos estabelecidos na legislação. Esse caráter de direito subjetivo é ainda evidenciado quando a própria MP 2.220/2001, em seu art. $6^{\circ}$, estabelece a possibilidade do título da CUEFM ser pleiteado na esfera judicial quando a Administração Pública ultrapassar o prazo de doze meses para decidir o pedido ou recusá-lo. Nessa senda, valemo-nos dos ensinamentos de Marques Neto:

[...] diferentemente do regime geral das concessões de uso, o direito do concessionário ao uso privativo antecede a concessão, prescinde de decisão favorável da Administração (o ato de outorga não é discricionário, mas vinculado) e desnecessita de licitação para selecionar o beneficiário. [...] $\mathrm{O}$ caráter de direito subjetivo à concessão especial para aquele que tiver preenchido a condição aquisitiva é reforçado pelo disposto no art. $6^{\circ}$ da MP 2.220/200, que assegura ao titular desse direito o recurso à via judicial para ver outorgada tal concessão. ${ }^{143}$

A MP 2.220/2001 tratou de regular, ainda, especificamente os imóveis utilizados para fins comerciais (art. $9^{\circ}$ da MP 2.220/2001), facultando ao Poder Público competente a autorizar o uso àquele que, até 30 de junho de 2001, possuiu como seu, por cinco anos, ininterruptamente e sem oposição, até duzentos e cinquenta metros quadrados de imóvel público situado em área urbana. Essa medida, no âmbito de projetos de regularização fundiária de interesse social, caracteriza o reconhecimento de que tais comunidades não são homogeneamente ocupadas apenas por moradia, tendo os pequenos comércios importante função local.

Por fim, antes de concluir a abordagem do instituto, cumpre destacar o debate acerca da constitucionalidade do art. $3^{\circ}$ da MP 2.220/2001 ${ }^{144}$ que prevê a aplicabilidade da CUEFM em relação aos imóveis dos Estados, Distrito Federal e Municípios, suscitada pelo Ministério Público do Estado de São Paulo, no âmbito do Processo no 990.10.274211-3 ainda em trâmite na $8^{\mathrm{a}}$ Câmara de Direito Público do TJSP:

A previsão genérica e uniforme de institutos jurídico-urbanísticos para

\footnotetext{
${ }^{143}$ MARQUES NETO, op. cit. 2009, p 361.

144 “Art. $3^{\circ}$ Será garantida a opção de exercer os direitos de que tratam os arts. $1^{\circ}$ e $2^{\circ}$ também aos ocupantes, regularmente inscritos, de imóveis públicos, com até duzentos e cinqüenta metros quadrados, da União, dos Estados, do Distrito Federal e dos Municípios, que estejam situados em área urbana, na forma do regulamento." (MP 2.220/2001)
} 
regularização fundiária se inclui na competência normativa da União, adstrita a normas gerais (art. 24, I, $\S 1^{\circ}$, CF). 3. A MProv 2.200/01 extrapolou esse âmbito ao tratar no art. $3^{\circ}$, de modo obrigatório, da concessão de uso especial para fins de moradia incidente sobre imóveis públicos dos Estados e dos Municípios, pois, regulou a utilização privativa de bens estaduais e municipais, matéria da alçada dos Estados, do Distrito Federal e dos Municípios, compreendida na sua autonomia (art. 18, CF). 4. Se diante da partilha de competências a União pode editar normas gerais, não lhe é dado obrigar Estados e Municípios à outorga de concessão de seus bens, cuja administração é exclusiva, suprimindo a liberdade de escolha dos institutos jurídicos de uso privativo de bem público.

Permitimo-nos discordar do entendimento exarado por uma razão muito simples: não é o art. $3^{\circ}$ da MP 2.220/2001 que estabelece a aplicabilidade da CUEFM aos Estados, Distrito Federal e Municípios, mas sim a própria Constituição Federal em seu art. 183. Foi possível constatar nos parágrafos anteriores do presente tópico que o dispositivo constitucional em questão, apesar da má redação do caput, abrange tanto o instituto da usucapião, voltada aos imóveis privados, quanto o título de concessão de uso, destinado aos de imóveis públicos. Além disso, nota-se que o dispositivo constitucional não faz qualquer limitação quanto à aplicabilidade do direito tratado, referindo-se apenas aos imóveis públicos da União. Sendo assim, não foi a União, por meio da MP 2.220/2001, que previu uma limitação à gestão de bens imóveis aos Estados, Distrito Federal e Municípios. A União apenas regulamentou um instituto que já tinha essa abrangência como decorrência da própria Constituição Federal.

\subsubsection{Aforamento}

O aforamento, também chamado de enfiteuse ${ }^{145}$, assim como os demais instrumentos analisados, confere ao beneficiário (foreiro) direitos reais de posse, uso e gozo pleno. Como regra geral, o mecanismo é utilizado com a condição de o foreiro pagar anualmente um valor (foro) ${ }^{146}$, por usufruir do domínio útil do bem e, na hipótese de

\footnotetext{
${ }^{145}$ Ambos os instrumentos são bastante semelhantes, mas o aforamento, apesar de mencionado no art. 678 do Código Civil de 1916, foi regulado no Decreto-Lei $\mathrm{n}^{\circ}$ 9.760/46 que trata especificamente de bens imóveis da União. A enfiteuse, por sua vez, foi regulada no Capítulo II do Título III - Dos Direitos Reais Sobre Coisas Alheias, do Código Civil de 1916, sendo aplicável sem referida limitação quanto ao detentor do domínio direto do bem. Entretanto, a própria legislação ora usa um termo ora usa o outro, como se representassem o mesmo mecanismo e, por essa razão, não faremos diferenciação.

146 “Art. 101 - Os terrenos aforados pela União ficam sujeitos ao foro de $0,6 \%$ (seis décimos por cento) do valor do respectivo domínio pleno, que será anualmente atualizado.” (Decreto-Lei n 9.760/46)
} 
alienação de tal domínio, em que o Poder Público opte por não exercer seu direito de preferência, o valor de 5\% do valor do imóvel (laudêmio) ao Poder Público.

O instituto foi praticamente retirado do sistema jurídico após a Constituição Federal de 1988 , tendo em vista o disposto no art. $49, \S 3^{\circ}$ do Ato das Disposições Constitucionais Transitórias, que restringiu aplicabilidade do mecanismo apenas aos terrenos de marinha e seus acrescidos.

No que se refere aos imóveis em relação aos quais permanece aplicável, a regulação do instituto pode ser encontrada no Decreto-Lei ${ }^{0}$ 9.760/1946, que após a Constituição Federal de 1988, foi alterado pela Lei $n^{0} 9.636 / 1998$ e pela Lei $n^{\circ}$ $11.481 / 2007$.

Cumpre salientar que o art. $1^{\circ}$ do Decreto-Lei $n^{\circ} 1.876 / 1981$ estabelece a isenção do pagamento de foros, taxas de ocupação e laudêmios, referentes a imóveis de propriedade da União, a pessoas consideradas carentes ou de baixa renda que tenham renda familiar mensal igual ou inferior ao valor correspondente a cinco salários mínimos.

Sendo assim, ainda que existam outros mecanismos a serem utilizados em processos de regularização fundiária de interesse social, a opção pelo aforamento, nos casos de imóveis da União situados em terrenos de marinha e seus acrescidos, continua sendo possível de ser adotada para tal finalidade.

\subsubsection{Doação}

Diferentemente dos demais instrumentos descritos no presente tópico, a doação caracteriza-se por ser uma modalidade contratual que importa em transferência da propriedade. Nos termos do disposto no art. 538 do Código Civil, considera-se doação o contrato em que, por liberalidade, estipula-se a transferência de bens ou vantagens do patrimônio de uma pessoa (doador) a outra (donatário). Tal contratação pode ser firmada com ou sem encargos, que variam desde a prestação de serviços até a remuneração em pecúnia (art. 540 do Código Civil).

Regulada essencialmente pelo Código Civil, já que em verdade as normas publicistas pouco abordam o tema, o instituto da doação sofre algumas adaptações quando utilizado pela Administração Pública, que não goza da mesma liberdade contratual se comparada aos particulares na gestão de seus negócios. 
Nesse sentido, a Lei $\mathrm{n}^{0} 8.666 / 1993$ cuidou de estabelecer dois principais requisitos gerais para que a Administração Pública utilize o instituto: (i) obrigatoriedade de lei autorizativa quando se tratar de doação de bem imóvel; e (ii) realização de licitação para escolha do doador, sendo imperativo o emprego da modalidade de concorrência para doações de bens imóveis. ${ }^{147}$

Destaca-se que a regra referente à imperatividade da realização de certame licitatório para a doação de bens imóveis é excepcionada justamente quando se está diante da utilização de tais bens para fins de regularização fundiária de interesse social.

Conforme se depreende do previsto no art. 17, quando desenvolvidos por órgãos ou entidades da administração pública, as seguintes doações ficam dispensadas de licitação: (i) emprego do bem imóvel em programas habitacionais ou de regularização fundiária de interesse social; (ii) bens imóveis de uso comercial de âmbito local com área de até $250 \mathrm{~m}^{2}$ (duzentos e cinquenta metros quadrados) e inseridos no âmbito de programas de regularização fundiária de interesse social; e (iii) terras públicas rurais da União na Amazônia Legal onde incidam ocupações até o limite de 15 (quinze) módulos fiscais ou 1.500ha (mil e quinhentos hectares), para fins de regularização fundiária, atendidos os requisitos legais. ${ }^{148}$

Cumpre salientar que os encargos expostos no art. $17 \S 1^{\circ},{ }^{149}$ referentes à possibilidade de reversão ao doador do bem objeto da doação, quando cessadas as razões que justificaram a doação, e a vedação à alienação do bem recebido pelo donatário, não se aplicam às hipóteses relacionadas à regularização fundiária de interesse social. Isso porque o $\S 1^{\circ}$ do art. 17 é claro ao indicar sua aplicabilidade apenas aos imóveis doados com base na alínea "b" do inciso I do art. 17. ${ }^{150}$ Ainda que haja ressalva mencionando as alíneas "f", "h" e "i", que tratam das hipóteses de doação para projetos de regularização fundiária de interesse social, as doações, nesse caso, são empreendidas com base em situações diversas

\footnotetext{
${ }^{147}$ Art. 17 , I e II da Lei n ${ }^{\circ} 8.666 / 1993$.

${ }^{148}$ Art. 17, I, alíneas "f", "h" e "i" da Lei no 8.666/1993.

149 “Art. $17, \S 1^{\circ}$ Os imóveis doados com base na alínea "b" do inciso I deste artigo, cessadas as razões que justificaram a sua doação, reverterão ao patrimônio da pessoa jurídica doadora, vedada a sua alienação pelo beneficiário.” (Lei no 8.666/1993) (grifo nosso)

150 “Art. 17, A alienação de bens da Administração Pública, subordinada à existência de interesse público devidamente justificado, será precedida de avaliação e obedecerá às seguintes normas: I - quando imóveis, dependerá de autorização legislativa para órgãos da administração direta e entidades autárquicas e fundacionais, e, para todos, inclusive as entidades paraestatais, dependerá de avaliação prévia e de licitação na modalidade de concorrência, dispensada esta nos seguintes casos: [...] b) doação, permitida exclusivamente para outro órgão ou entidade da administração pública, de qualquer esfera de governo, ressalvado o disposto nas alíneas f, h e i;" (Lei no 8.666/1993) (grifo nosso)
} 
da mencionada na alínea "b". Se a intenção fosse vincular os encargos a qualquer tipo de doação sem licitação, o dispositivo não indicaria apenas a situação prevista na alínea "b", mas expandiria para as alíneas "f", "h" e "i".

Por fim, ressalta-se a recente disciplina sobre o tema no que se refere a processos de regularização fundiária de interesse social em terras da União na Amazônia Legal. De acordo com a Lei $n^{0} 11.952 / 2009$, os Municípios interessados receberão doação da União para a realização de atos voltados para a regularização fundiária ${ }^{151}$, dentre os quais se destaca a possibilidade de doação gratuita de tais terras da União diretamente a beneficiários que cumpram os requisitos previstos no art. 30 , inciso I da referida lei. ${ }^{152}$

\subsection{2 Áreas privadas: usucapião especial urbana}

No tocante às áreas privadas, o único instrumento destinado apenas à legalização do exercício da posse é a usucapião especial coletiva. Portanto, ainda que outros instrumentos sejam aplicáveis em decorrência do caráter misto que engloba tanto regularização dominial quanto regularização urbanística, seu tratamento será realizado em tópico próprio.

A previsão da usucapião como instituto voltado à aquisição originária da propriedade não é recente no ordenamento jurídico. Suas modalidades, aplicáveis apenas às propriedades privadas ${ }^{153}$, encontram-se previstas na Constituição Federal $^{154}$, no Código Civil $^{155}$ e no Estatuto da Cidade ${ }^{156}$. Importa, porém, ao presente estudo a análise apenas

\footnotetext{
151 “Art. 21. São passíveis de regularização fundiária as ocupações incidentes em terras públicas da União, previstas no art. $3^{\circ}$ desta Lei, situadas em áreas urbanas, de expansão urbana ou de urbanização específica. § $1^{\circ}$ A regularização prevista no caput deste artigo será efetivada mediante doação aos Municípios interessados, para a qual fica o Poder Executivo autorizado, sob a condição de que sejam realizados pelas administrações locais os atos necessários à regularização das áreas ocupadas, nos termos desta Lei."

152 "Art. 30. O Município deverá realizar a regularização fundiária dos lotes ocupados, observados os seguintes requisitos: I - alienação gratuita a pessoa natural que tenha ingressado na área antes de 11 de fevereiro de 2009, atendidas pelo beneficiário as seguintes condições: a) possua renda familiar mensal inferior a 5 (cinco) salários mínimos; b) ocupe a área de até $1.000 \mathrm{~m}^{2}$ (mil metros quadrados) sem oposição, pelo prazo ininterrupto de, no mínimo, 1 (um) ano, observadas, se houver, as dimensões de lotes fixadas na legislação municipal; c) utilize o imóvel como única moradia ou como meio lícito de subsistência, exceto locação ou assemelhado; e d) não seja proprietário ou possuidor de outro imóvel urbano, condição atestada mediante declaração pessoal sujeita a responsabilização nas esferas penal, administrativa e civil;" Destaca-se que a Lei utiliza o termo alienação para doação ou venda (art. $2^{\circ}$, inciso IX da Lei $n^{\circ} 11.952 / 2009$ )

${ }^{153}$ Por força das vedações previstas nos seguintes dispositivos: art. 183, § $3^{\circ}$ e art. 191, parágrafo único, ambos da CF, e art. 102 do Código Civil.

${ }^{154}$ Artigos 183 e 191 da Constituição Federal.

${ }^{155}$ Artigos 1.238, 1.239, 1.240, 1.240-A e 1.242 do Código Civil.

${ }^{156}$ Artigos $9^{\circ}$ e 10 do Estatuto da Cidade.
} 
das modalidades de usucapião especial urbana, pois, diante dos seus requisitos, é possível afirmar que "a ratio inspiradora dessa usucapião foi a busca de uma solução para o problema aparentemente insolúvel da moradia nas grandes cidades, direcionando os imóveis urbanos para a realização da função social. "157

Conforme o disposto no art. 183 da Constituição Federal, tem o direito a adquirir o domínio pleno da propriedade de área urbana de até $250 \mathrm{~m}^{2}$ (duzentos e cinquenta metros quadrados), aquele que a possuir como sua, por 5 (cinco) anos, ininterruptamente e sem oposição, desde que utilize o local para sua moradia ou de sua família e não seja proprietário de outro imóvel urbano ou rural. A previsão constitucional destaca, ainda, a possibilidade do título de domínio ser conferido ao homem ou à mulher, ou a ambos, independentemente do estado civil e a impossibilidade de ser reconhecido a um mesmo possuidor mais de uma vez. ${ }^{158}$

Regulando referido dispositivo, o Estatuto da Cidade previu, com algumas alterações pontuais do texto constitucional, duas modalidades em que tais critérios seriam aplicados: (i) a individual e (ii) a coletiva. Antes, porém, de iniciar o tratamento de cada um delas em específico, cumpre apresentar algumas características que se aplicam a ambas as modalidades.

Primeiramente, em relação ao conteúdo da expressão "área urbana", notadamente em relação ao termo "urbana", duas são as possibilidades consideradas pela doutrina: (i) assumir como urbana a área localizada em zona urbana, conforme previsão do Plano Diretor ou, (ii) admitir como urbana a área que tenha destinação urbana, ou seja, tenha uso predominantemente para fins de moradia e não para fins de exploração econômico-rural, independentemente da zona em que está inserida.

A nosso ver, se a intenção da Constituição Federal fosse no sentido de restringir a aplicabilidade do mecanismo para área urbana inserida em zona urbana, assim teria feito expressamente, como o fez na hipótese de usucapião prevista no art. 191 ao indicar “terreno em zona rural". E mais, adotar esse entendimento acaba por restringir a aplicabilidade da usucapião, já que o zoneamento apresenta como característica central o caráter estático que em muito conflita com a dinâmica da expansão urbana dos Municípios.

\footnotetext{
${ }^{157}$ HORBACH, Carlos Bastide. Dos instrumentos da política urbana, Da usucapião especial urbana. Da concessão de uso especial para fins de moradia. In: ALMEIDA, Fernando Menezes de; MEDAUAR, Odete (coord.). Estatuto da Cidade - Lei $n^{\circ}$ 10.527, de 10.07.2001: Comentário. 2. ed. São Paulo: Malheiros, 2004, p. 132.

${ }^{158}$ Ambos os requisitos aplicam-se à CUEFM, conforme já mencionado em tópico dedicado ao tema.
} 
Não é incomum que áreas definidas como zona rural tenham imóveis que não desenvolvem atividade econômica rural, prevalecendo o uso tão somente destinado à moradia. Como não houve no texto constitucional essa delimitação, não há razão para que o intérprete o faça no sentido de restringir a abrangência do direito constitucionalmente garantido à usucapião especial urbana.

Destaca-se, contudo, que a Lei do Programa Minha Casa, Minha Vida, em seu art. 47, adota a primeira interpretação e estabelece, para fins de regularização fundiária de assentamentos urbanos, que área urbana equivale à parcela do território, contínua ou não, incluída no perímetro urbano pelo Plano Diretor ou por lei municipal específica. Considerando o ordenamento jurídico como um todo e na ausência de uma delimitação conceitual acerca da matéria no Estatuto da Cidade, que regulou as modalidades de usucapião especial urbana, prevalece o entendimento no sentido de que "área urbana" é aquela inserida na zona urbana identificada do Plano Diretor ou na lei municipal.

São, ainda, características comuns as seguintes: (i) sobrestamento de quaisquer ações, petitórias ou possessórias, que venham a ser propostas relativamente ao imóvel que já esteja com processo judicial de usucapião em curso; (ii) são legitimados para a propositura da ação o possuidor, isoladamente ou em litisconsórcio originário ou superveniente, os possuidores, em estado de composse, ou como substituto processual, a associação de moradores da comunidade; (iii) intervenção obrigatória do Ministério Público; (iv) benefícios da justiça e da assistência judiciária gratuita, inclusive perante o cartório de registro de imóveis, ${ }^{159}$ aos autores da ação; e (v) rito processual sumário na ação judicial de usucapião especial de imóvel urbano.

Feitos tais apontamentos aplicáveis a ambas as modalidades de usucapião especial

\footnotetext{
${ }^{159}$ A matéria referente ao registro público dos títulos de propriedade ou posse decorrentes de processos de regularização fundiária de interesse social foi questão estratégica do governo federal, já em 2003, quando foi desenvolvido o Programa Nacional de Apoio à Regularização Fundiária Sustentável. Relata Edésio Fernandes: "Dados os inúmeros relatos provenientes de pessoas de diversas partes do país, indicando a impossibilidade de levar a cabo o registro da regularização fundiária - o que se torna indispensável, dado o caráter constitutivo do registro imobiliário no Brasil-, o Programa convocou uma Jornada de Discussões Temáticas sobre a questão para identificar a origem da dificuldade, bem como para apontar alternativas para superação. Nessa oportunidade, foram identificadas três ordens de problemas: os altos custos do registro, os procedimentos exigidos para o registro da regularização; e as práticas dos cartórios e oficiais de registro que estariam inviabilizando o avanço dos programas municipais e estaduais de regularização." (Princípios, Bases e Desafios de uma Política Nacional de Apoio à Regularização Fundiária Sustentável. In: ALFONSIN, Betânia e FERNANDES, Edésio. Direito à Moradia e Segurança da Posse no Estatuto da Cidade. Belo Horizonte: Editora Fórum, 2004, p. 336-337. Atualmente, tais questões encontram-se equacionadas já que foram realizadas alterações na legislação no sentido a obrigatoriedade de registro e sua gratuidade. Outras questões, entretanto, podem surgir a partir da nova sistemática para a demarcação urbanística e legitimação da posse, em que o procedimento ocorre no próprio cartório de registro de imóveis.
} 
urbana, importa apresentar suas especificidades.

\subsubsection{Modalidade individual}

No que se refere à usucapião individual, o art. $9^{\circ}$ do Estatuto da Cidade praticamente copiou o texto constitucional, acrescentando, entretanto, dois delineamentos para a aplicação do instituto.

O primeiro refere-se à outra delimitação do conceito da expressão "área urbana", mas agora em relação à abrangência do termo "área". O caput do art. $9^{\circ}$ do Estatuto da Cidade, além de prever a "área" urbana, inclui o termo "edificação" urbana, positivando entendimento no sentido de que o próprio conteúdo do termo "área" previsto na norma constitucional já tinha o condão de abranger a área do terreno ou a área da edificação nesta inserida. $^{160}$

O segundo autoriza que o herdeiro legítimo some, de pleno direito, a posse de seu antecessor, desde que já resida no imóvel por ocasião da abertura da sucessão, privilegiando o herdeiro que, em conjunto com seu antecessor, exerceu a posse da área urbana para fins de moradia. Essa medida vinha ao encontro do entendimento doutrinário dominante à época, pois essa soma apenas seria possível quando o herdeiro também exercesse a posse. ${ }^{161}$ Nota-se que, após a aprovação do novo Código Civil, em 2002, a possibilidade de soma das posses, seja herdeiro ou não, passou a ser permitida no art. $1.243^{162}$ em qualquer das modalidades de usucapião para fins de comprovação do tempo de exercício da posse que gera a prescrição aquisitiva da propriedade.

\footnotetext{
${ }^{160}$ Prevaleceu, nesse sentido, o entendimento adotado por Celso Ribeiro Bastos, ao comentar o dispositivo constitucional: "Para nós, a área urbana a que se refere a Constituição deve ser entendida tanto em razão do terreno quando da construção. Não tendo feito o Texto Constitucional discriminação entre uma e outra, é óbvio que quis englobá-las. É de inteira aplicação aqui o brocado segundo o qual onde o texto não distingue não cabe ao intérprete distinguir." (BASTOS, Celso Ribeiro; MARTINS, Ives Gandra da Silva. Comentários à Constituição do Brasil. São Paulo: Saraiva, $7^{\circ}$ volume, 1990, p. 231).

161 “A grande maioria dos autores, ao analisar o tema concluiu pela impossibilidade de transmissão da posse ao sucessor singular, na accessio possessionis, uma vez que a ocupação para moradia exigida pela Constituição é pessoal. Por outro lado, relativamente à successio possessionis, o art. 496 seria parcialmente aplicável, desde que o sucessor seja pessoa da família habitante do imóvel usucapiendo." (HORBACH, op. cit., p. 134).

162 Segundo o disposto no art. 1.243, o possuidor pode, para o fim de contar o tempo exigido pelos artigos antecedentes, acrescentar à sua posse a dos seus antecessores (art. 1.207), contanto que todas sejam contínuas, pacíficas e, nos casos do art. 1.242, com justo título e de boa-fé.
} 


\subsubsection{Modalidade coletiva}

Em relação à usucapião especial coletiva, o art. 10 do Estatuto da Cidade estabelece algumas peculiaridades na hipótese de incidência da norma, até para adequação do instituto ao caráter coletivo. São elas: (i) a especificação da população de baixa renda como destinatária do instituto; (ii) no lugar da área máxima, a previsão de área mínima de $250 \mathrm{~m}^{2}$ (duzentos e cinquenta metros quadrados); (iii) a impossibilidade de identificar os terrenos ocupados por cada possuidor; (iv) a possibilidade do título ser reconhecido ao mesmo possuidor mais de uma vez.

Os demais critérios permanecem os mesmos, quais sejam, uso da área para fins de moradia, por cinco anos, ininterruptamente e sem oposição, desde que os possuidores não sejam proprietários de outro imóvel urbano ou rural.

Além disso, são também características dessa modalidade de usucapião: (i) possibilidade de acrescentar sua posse à de seu antecessor, contanto que ambas sejam contínuas; ${ }^{163}$ (ii) a sua declaração em juízo, a qual servirá de título para registro no cartório de registro de imóveis; ${ }^{164}$ e (iii) a criação de um condomínio, que somente será extinto por deliberação favorável tomada por, no mínimo, dois terços dos condôminos, no qual todos os possuidores detém igual fração ideal de terreno, ressalvadas as hipóteses de acordo escrito entre os condôminos, estabelecendo frações ideais diferenciadas. ${ }^{165}$

Nota-se que há algumas diferenças entre as modalidades individual e a coletiva. Em razão disso, parte da doutrina entende que o Estatuto da Cidade não apenas regulou o previsto no art. 183 da Constituição Federal, mas inaugurou um novo tipo de usucapião. Como consequência desse entendimento, o prazo para prescrição da aquisitiva da propriedade passaria a contar apenas da edição do Estatuto da Cidade em 2001, tendo em vista a necessidade dos proprietários terem ciência prévia das consequências a que podiam estar sujeitas suas propriedades, desconsiderando o período entre a aprovação da Constituição Federal e o Estatuto da Cidade para fins de contabilização do prazo.

Apesar da irrelevância da discussão atualmente, já que para fins de configuração do direito em 2013 bastaria o início da posse ser comprovado a partir de 2008, muito tempo

\footnotetext{
${ }^{163}$ Art. $10, \S 1^{\circ}$ do Estatuto da Cidade.

${ }^{164}$ Art. $10, \S 2^{\circ}$ do Estatuto da Cidade.

${ }^{165}$ Art. $10, \S 3^{\circ}$ e $\S 4^{\circ}$ do Estatuto da Cidade.
} 
depois do Estatuto da Cidade, cumpre pontuar nosso entendimento.

O fato de haver certa especificidade na previsão da modalidade coletiva da usucapião especial urbana não conduz o intérprete à conclusão necessária de que se trata de mecanismo com características inexistentes no ordenamento jurídico até a edição do Estatuto da Cidade. Como bem ressaltou Dalmo Dallari acerca da finalidade do disposto no art. 183 da Constituição Federal:

\begin{abstract}
A expressão "aquele que possuir" não implica "possuir sozinho", quem possuir em comum, o copossuidor, pode ser referido como "aquele que possuir", assim como o condomínio estará incluído nos dispositivos legais que fizerem referência àquele que for proprietário. No caso do artigo 183 da Constituição, pode-se afirmar, com absoluta segurança, que o constituinte sabia que a posse urbana para moradia é sempre coletiva, sendo extremamente raras as exceções. Estas, por sua raridade e por sua pequena expressão social, não justificariam uma disposição constitucional inovadores. Assim, portanto, sem qualquer sombra de dúvida, o artigo 183 da Constituição Brasileira permite que se use o caminho tradicional da usucapião para, tendo por base a posse comum, se obter a usucapião coletiva. ${ }^{166}$
\end{abstract}

Tomando por base os elementos diferenciadores entre as modalidades individual e coletiva, observa-se que todas as especificações empreendidas têm o condão de garantir ou reforçar o caráter social da aplicabilidade da medida coletiva, por isso incluir a população de baixa renda que vive em condições inadequadas de moradia, caracterizadas pela impossibilidade de individualização dos lotes.

Adotar o entendimento de que o marco temporal para o início da contagem do prazo seja a edição do Estatuto da Cidade equivaleria a reconhecer que, mesmo diante da nova ordem constitucional e dos princípios da função social da propriedade, defesa do meio ambiente, redução das desigualdades sociais, garantia do bem estar dos habitantes da cidade, dignidade da pessoa humana, justiça e solidariedade sociais, erradicação da pobreza e da marginalização, ${ }^{167}$ deveriam ser desprezados em prol da segurança jurídica do proprietário que teve catorze anos, entre a aprovação da Constituição Federal até o Estatuto da Cidade, para dar a sua propriedade a devida função social ou, ainda, buscar qualquer tipo de medida para retomada da posse.

\footnotetext{
${ }^{166}$ DALLARI, Dalmo. Usucapião Coletivo. In: Revista Informativa Legislativa, Brasília, a. 29 n. 115, jul/set, 1992, p 379-380.

${ }^{167}$ FERRAZ, op. cit., 2003, p. 144.
} 


\subsection{Instrumentos para compatibilização dos assentamentos às normas urbanísticas}

Pontuados os institutos voltados à regularização fundiária de interesse social em relação aos aspectos dominiais ou de legalização do exercício da posse, importa discorrer acerca dos instrumentos utilizados para a compatibilização das ocupações irregulares às normas urbanísticas, compreendidas nesse conceito as normas relacionadas a parcelamento, uso e ocupação do solo e das edificações.

\subsubsection{Zona especial de interesse social}

A Zona Especial de Interesse Social (ZEIS) é mecanismo pouco detalhado no âmbito da legislação federal, conforme será demonstrado. Essa constatação leva-nos a duas conclusões. A primeira, mais evidente, relaciona-se à necessidade de garantir ampla liberdade para que o Município discipline o tema de acordo com suas necessidades e conforme as peculiaridades de cada de suas ZEIS. A segunda pode decorrer do fato do instituto ter sido amplamente utilizado por Municípios muito antes da aprovação do Estatuto da Cidade, estando de certo modo enraizado nas políticas urbanas.

Sendo assim, antes de iniciar a abordagem da legislação, cumpre trazer à baila duas experiências relevantes sobre a utilização do mecanismo, que ocorreram em Recife e em Diadema, na década de 1980.

Em Recife dois momentos marcaram a evolução do instituto e acabaram servindo como referência para sua adoção no país. Em 1983, a Lei de Parcelamento de Solo de Recife identificou áreas como ZEIS com a finalidade de regularizá-las e, posteriormente, integrá-las à estrutura formal das cidades. Entretanto, além da demarcação ter abrangido apenas em torno de $15 \%$ das favelas existentes na época, quando as ZEIS passavam a ser integradas à estrutura formal, as regras tradicionais de uso e ocupação do solo prevaleciam e passavam a expulsar naturalmente a população de baixa renda dos locais.

Com o Plano de Regularização das ZEIS (PREZEIS), que correspondia à regulamentação da referida lei, aliado ao processo de redemocratização do país e ao fortalecimento das organizações de bairro, houve a inclusão de novas áreas e alguns mecanismos foram inseridos para evitar o desvirtuamento da ZEIS, destacando-se: (i) a fixação de dimensões máximas dos lotes; (ii) proibição de remembramento de lotes; (iii) a 
institucionalização de canais de participação da população envolvida dos processos de regularização fundiária. Tais mecanismos garantiram a institucionalização do PREZEIS, com destaque para a aprovação do Fundo do PREZEIS. ${ }^{168}$

No caso de Diadema, o mecanismo envolveu duas diferentes diretrizes. A primeira foi reservar vazios urbanos para provimento futuro de novos núcleos habitacionais de interesse social (Áreas Especiais de Interesse Social 1 - AEIS1). A segunda foi demarcar áreas já ocupadas por população de baixa renda para realização de projetos de urbanização (Áreas Especiais de Interesse Social 2 - AEIS2). Com ambas as medidas, o Município conseguiu ampliar o mercado de terras para a população de baixa renda e evitar a ocupação em áreas de mananciais. Diante, contudo, da proximidade de Diadema com outros municípios e a intensa e rápida comercialização de áreas destinadas a atender o mercado voltado para a população de baixa renda, as ocupações irregulares expandiram-se novamente. ${ }^{169}$

Tomando como base tais experiências, passamos à análise da legislação federal acerca da temática, com o intuito de demonstrar a generalidade dos dispositivos que acabam por albergar diversas soluções envolvendo o instituto da ZEIS.

$\mathrm{Na}$ esfera federal, o art. 47, inciso $\mathrm{V}$, da Lei $\mathrm{n}^{0}$ 11.977/2009 cuidou de definir a ZEIS como "parcela de área urbana instituida pelo Plano Diretor ou definida por outra lei municipal, destinada predominantemente à moradia de população de baixa renda e sujeita a regras especificas de parcelamento, uso e ocupação do solo."

Seguindo a mesma lógica, o Estatuto da Cidade arrola a ZEIS dentre os institutos jurídicos da política urbana ${ }^{170}$ e estabelece a obrigatoriedade da demarcação de zona especial de interesse social como forma de garantir áreas para habitação de interesse social, nos Planos Diretores dos Municípios que pretendem ampliar seu perímetro urbano ${ }^{171}$ ou são incluídos no cadastro nacional de municípios com áreas suscetíveis à ocorrência de deslizamentos de grande impacto, inundações bruscas ou processos geológicos ou hidrológicos correlatos. ${ }^{172}$

\footnotetext{
${ }^{168}$ ROLNIK, op. cit., 2002, p. 157.

${ }^{169}$ ROLNIK, op. cit., 2002, p. 158.

${ }^{170}$ Art. $4^{\mathrm{o}}$, inciso V, alínea "f" do Estatuto da Cidade.

171 "Art. 42-B. Os Municípios que pretendam ampliar o seu perímetro urbano após a data de publicação desta Lei deverão elaborar projeto específico que contenha, no mínimo: [...] V - a previsão de áreas para habitação de interesse social por meio da demarcação de zonas especiais de interesse social e de outros instrumentos de política urbana, quando o uso habitacional for permitido." (Estatuto da Cidade).

172 “Art. 42-A. Além do conteúdo previsto no art. 42, o plano diretor dos Municípios incluídos no cadastro nacional de municípios com áreas suscetíveis à ocorrência de deslizamentos de grande impacto, inundações
} 
De maneira simplificada, portanto, por meio da ZEIS o Município demarca determinada área para implantar projetos voltados para moradia da população de baixa renda, estando autorizado a estabelecer regras específicas de parcelamento, uso e ocupação do solo.

$\mathrm{Na}$ ausência de delimitação, as regras específicas podem abranger tanto àquelas voltadas para facilitação da aprovação de projetos de regularização fundiária perante o Poder Público quanto às destinadas para executar projetos de habitação de interesse social, com o estabelecimento de padrões de construção diferenciados se comparados às construções empreendidas pelo mercado imobiliário em situações usuais.

No mesmo sentido, a aplicabilidade a projetos voltados para moradia da população de baixa renda pode abranger diversas situações concretas. A primeira delas seria demarcar áreas no perímetro urbano que já estejam ocupadas predominantemente por população de baixa renda, como favelas, loteamentos irregulares, conjuntos habitacionais irregulares e cortiços, para ali desenvolver projetos de regularização fundiária de interesse social. Acerca dessa primeira vertente de utilização do instituto, ensina Adilson de Abreu Dallari:

As zonas especiais de interesse social são aquelas onde as circunstâncias de fato autorizam ou determinam um tratamento diferenciado, mais simples, menos elitista, dos índices urbanísticos de maneira a assegurar o direito à moradia, inserido no art. $6^{\circ}$ da Constituição Federal pela Emenda Constitucional 26, de 14.2.2002. Não se trata de criar privilégios para os economicamente fracos, nem de lhes conferir menos garantias de salubridade e segurança, mas, sim, de aplicar o direito com razoabilidade, promovendo entre os diversos objetivos e valores constitucionalmente consagrados. ${ }^{173}$

Outra utilidade não menos relevante seria utilizar o mecanismo da ZEIS, nos moldes do modelo adotado por Diadema, para demarcação de áreas no perímetro urbano em relação às quais ainda não exista ocupação por população de baixa renda, mas há intenção do Poder Público municipal em realizar projetos para incluir tais populações em regiões específicas da cidade. Nessa hipótese, o instituto serviria como mecanismo destinado a reservar espaços da cidade para o mercado de habitação de interesse social, por meio do estabelecimento de padrões diferenciados a serem atendidos nas áreas demarcadas.

bruscas ou processos geológicos ou hidrológicos correlatos deverá conter: [...] V- diretrizes para a regularização fundiária de assentamentos urbanos irregulares, se houver, observadas a Lei no 11.977, de 7 de julho de 2009, e demais normas federais e estaduais pertinentes, e previsão de áreas para habitação de interesse social por meio da demarcação de zonas especiais de interesse social e de outros instrumentos de política urbana, onde o uso habitacional for permitido." (Estatuto da Cidade).

${ }^{173}$ DALLARI, Adilson Abreu. Instrumentos de Política Urbana. In: Estatuto da Cidade: comentários à Lei Federal $n^{o}$ 10.257/2001. São Paulo: Malheiros, 2002, p. 81. 
A legislação federal não faz qualquer menção à necessidade de realização de Plano de Urbanização no âmbito da ZEIS, mas diversos Planos Diretores assim o fazem ${ }^{174}$. Essa medida, além de contribuir para o planejamento da intervenção urbanística, caso já haja ocupação no local, permite o envolvimento da população diretamente atingida nos processos decisórios que envolvem o planejamento e a execução de urbanização nesses locais.

\subsubsection{Operações urbanas consorciadas}

Outro instrumento que pode ser arrolado como mecanismo apto a contribuir para a regularização fundiária, especialmente no tocante às melhorias urbanísticas dos assentamentos irregulares nas cidades, é a operação urbana consorciada prevista nos artigos $4^{\circ}$, inciso IV, alínea "p", e 32 a 34 do Estatuto da Cidade.

O Estatuto cuidou de inserir as operações urbanas no rol dos instrumentos jurídicos da política urbana que, por sua vez, apresenta como objetivo ordenar o pleno desenvolvimento das funções sociais da cidade e da propriedade urbana. Isso significa afirmar que a utilização do instituto está voltada aos objetivos da política urbana, que serão atingidos mediante o cumprimento das diretrizes gerais fixadas no art. $2^{\circ}$ do Estatuto da Cidade. Ou seja, são as diretrizes gerais que fornecem o subsídio necessário para a interpretação e para a utilização do aparato instrumental previsto no Estatuto. Nessa senda, partilhamos do entendimento de Betânia de Moraes Alfonsin:

[...] a operação urbana deverá estar conforme as diretrizes do Estatuto da Cidade, ou seja, não é legal e pode ser anulada a operação urbana que, por exemplo, concentre benefícios da urbanização nas mãos de proprietários de glebas, isso porque, sabidamente, a justa distribuição dos benefícios e ônus decorrentes do processo de urbanização é diretriz da Política Urbana a ser implementada pelos municípios brasileiros. ${ }^{175}$

É evidente que reconhecemos a dificuldade de identificar empiricamente o descumprimento da mencionada diretriz, principalmente considerando a política urbana

\footnotetext{
${ }^{174}$ Nesse sentido: art. $157, \S 3^{\circ}$, inciso V do Plano Diretor de São Paulo; art. 32, inciso V do Plano Diretor do Recife.

175 ALFONSIN, Betânia. Operações urbanas consorciadas como instrumento de captação de mais-valias urbanas: um imperativo da nova ordem jurídico-brasileira. In: Direito Urbanístico Estudos Brasileiros e Internacionais, ALFONSIN, Betânia; FERNANDES, Edésio (coord.), Belo Horizonte: Del Rey e Boston: Lincoln Institute os Land Policy, 2006, p. 290.
} 
como um todo, ou seja, os impactos da operação consorciada para além do perímetro da própria operação. Entretanto, a intenção é fixar a importância de o mecanismo ser orientado no sentido de distribuir os benefícios da urbanização por ele gerados, já que, na ordem jurídica atual, não há espaço para a implementação de políticas que intensifiquem as desigualdades também no tocante ao território das cidades.

Tendo fixado tal premissa, de acordo com o disciplinado pelo Estatuto, lei municipal específica, baseada no plano diretor, poderá delimitar área para aplicação de operações consorciadas que se caracterizam pelo conjunto de intervenções e medidas coordenadas pelo Poder Público municipal, com a participação dos proprietários, moradores, usuários permanentes e investidores privados, tendo como objetivos a realização de transformações urbanísticas estruturais, melhorias sociais e a valorização ambiental.

A coordenação mencionada na definição, encontra respaldo nas diretrizes da política urbana ao mencionar a necessidade de "cooperação entre os governos, a iniciativa privada e os demais setores da sociedade no processo de urbanização, em atendimento ao interesse social ${ }^{\text {"176 }}$ e a menção à participação, é entendida no âmbito da diretriz acerca da gestão democrática a conduzir a política urbana. ${ }^{177}$

Por meio da operação urbana consorciada fica o Poder Público municipal autorizado a estabelecer um conjunto de alteração, que envolva os índices e características de parcelamento, uso e ocupação do solo e subsolo, bem como as normas edilícias, e, ainda, a regularização de construções, reformas ou ampliações executadas em desacordo com a legislação vigente. A realização de tais alterações deve coincidir com a finalidade do instituto, qual seja a realização de transformações urbanísticas estruturais, de melhorias sociais e a valorização ambiental, entendidos como objetivos a serem atingidos conjuntamente.

Para tanto, diferentemente da ZEIS, no caso das Operações Urbanas Consorciadas, o Estatuto da Cidade especificou a necessidade de elaboração do plano de operação urbana consorciada, contendo, no mínimo: (i) definição da área a ser atingida; (ii) programa básico de ocupação da área; (iii) programa de atendimento econômico e social para a população diretamente afetada pela operação; (iv) finalidades da operação; (v) estudo prévio de impacto de vizinhança; (vi) contrapartida a ser exigida dos proprietários, usuários permanentes e investidores privados em função da utilização dos benefícios decorrentes dos benefícios

\footnotetext{
${ }^{176}$ Art. $2^{\circ}$, inciso III do Estatuto da Cidade.

${ }^{177}$ art. $2^{\circ}$, inciso II do Estatuto da Cidade.
} 
previstos nos incisos I e II do $§ 20$ do art. 32 desta Lei; (vii) forma de controle da operação, obrigatoriamente compartilhado com representação da sociedade civil.

O fato de o plano prever a exigência de contrapartida dos proprietários, usuários permanentes e investidores privados, confere ao instituto uma ampla gama de possibilidades para alavancar recursos para os investimentos públicos na área delimitada pela operação urbana. Apenas para mencionar, já que a abordagem detalhada do tema está compreendida no Capítulo IV dedicado aos mecanismos aptos a viabilizarem investimentos em projetos da regularização fundiária de interesse social, há possibilidade da lei que aprovar a operação prever a emissão pelo Município de quantidade determinada de certificados de potencial adicional de construção (CEPAC), que serão alienados em leilão ou utilizados diretamente no pagamento das obras necessárias à própria operação e, ainda, outros instrumentos capazes de capturar a mais-valia gerada pela operação urbana.

No caso das operações urbanas, apesar da finalidade do instituto não estar voltada exclusivamente para a promoção de habitação de interesse social ou regularização fundiária de interesse social, sua formulação e execução pode incluir processos de regularização fundiária de interesse social como forma de garantir que os benefícios gerados a partir da criação de operações urbanas consorciadas sejam distribuídos de modo equitativo, incluindo a população de baixa renda, seguindo as diretrizes do Estatuto da Cidade.

\subsubsection{Consórcio imobiliário}

O consórcio imobiliário se aproxima do direito de superfície, examinado adiante, tendo em vista que ambos os institutos acabam por contribuir para a viabilização de planos de urbanização ou edificação em imóveis não edificados, subutilizados ou não utilizados. No caso do consórcio imobiliário, porém, a questão dominial é tratada de modo diverso.

Enquanto no direito de superfície há tão somente a transferência do domínio útil do imóvel para o Poder Público ou para terceiros com a finalidade de realização de obras e investimentos no bem, a título oneroso ou gratuito, no consórcio imobiliário a relação sempre será onerosa e importará em transferência do domínio pleno de parcela do imóvel ao final da realização das obras.

Segundo o art. 46, $\S 1^{\circ}$, do Estatuto da Cidade, por meio do consórcio imobiliário, o proprietário de imóvel situado em área atingida pela obrigação de que trata o caput do art. 
$5^{\circ}$ do Estatuto da Cidade transfere ao Poder Público o bem para a realização de obras e viabilização de planos de urbanização e edificação, recebendo como pagamento as unidades imobiliárias devidamente urbanizadas ou edificadas no valor correspondente ao valor do imóvel antes da execução das obras, observado o disposto no $\S 2^{\circ}$ do art. $8^{\circ}$ do Estatuto da Cidade que disciplina a indenização na hipótese de desapropriação sanção.

A legislação estabelece que o consórcio deve ser requerido pelo proprietário. Todavia, nada impede que o próprio Município na realização da política urbana, utilizando suas atribuições como ente responsável por ordenar o pleno desenvolvimento das funções sociais da cidade e da propriedade urbana, identifique áreas de interesse e ele próprio busque os particulares para a formalização de consórcios imobiliários.

A formalização do consórcio deve ser empreendida por meio de contrato que estabeleça os prazos e as condições para a transferência do terreno e para a realização das obras, bem como, antes da realização dos investimentos, estabeleça o valor do imóvel que será utilizado como referência para a contrapartida pública a ser paga após as intervenções.

No âmbito da regularização fundiária de interesse social, o instituto pode contribuir para: (i) construção de loteamentos populares ou conjuntos habitacionais de interesse social; (ii) reforma de prédios e imóveis não utilizados, situados em regiões estratégicas; (iii) realização de obras para construção de equipamentos urbanos e comunitários em regiões carentes de equipamentos e serviços; e (iii) urbanização e legalização do domínio em áreas ocupadas por população de baixa renda. ${ }^{178}$

Nesse sentido, Saule Júnior destaca a importância do instrumento em processos de regularização fundiária de interesse social, identificando algumas situações específicas que poderiam ser priorizadas na aplicação:

a) Área particular ocupada por população de baixa renda contendo litígio judicial mediante ação judicial (reintegração de posse), promovida pelo proprietário, solicitando a remoção da população ocupante. Área onde a ocupação já tenha uma longa duração e esteja consolidada para habitação de interesse social.

b) Área particular ocupada por população de baixa renda, cuja ocupação tenha duração inferior a cinco anos, e sem litígio judicial, que apresente condições urbanísticas favoráveis a ser destinada para fins de habitação de interesse social. ${ }^{179}$

Tais situações, evidentemente, não têm a pretensão de esgotar as possibilidades de

\footnotetext{
${ }^{178}$ SAULE JUNIOR, op. cit., 2004, p. 329-330.

${ }^{179}$ SAULE JUNIOR, op. cit., 2004, p. 330.
} 
utilização do instituto para fins de regularização fundiária de interesse social, mas apenas suscitar situações frequentemente encontradas nas cidades e que poderiam ser solucionadas por meio da utilização do instituto.

\subsection{Instrumentos que apresentam ambas as finalidades}

Os instrumentos a seguir analisados apresentam características que impedem seu estudo de modo a separar a regularização dominial da regularização urbanística ou, ainda, área pública e área privada. Por tais razões, optou-se por separar a análise, já destacando essa característica que será observada em todos eles no sentido de ser útil para a regularização fundiária justamente por mesclar as finalidades abrangidas nos processos de regularização fundiária urbana de interesse social.

\subsubsection{Demarcação urbanística}

A demarcação urbanística é instrumento recentemente inaugurado pela Lei do Programa Mina Casa, Minha Vida em seu art. 47, inciso III, que a define como:

[...] procedimento administrativo pelo qual o poder público, no âmbito da regularização fundiária de interesse social, demarca imóvel de domínio público ou privado, definindo seus limites, área, localização e confrontantes, com a finalidade de identificar seus ocupantes e qualificar a natureza e o tempo das respectivas posses.

Trata-se de processo no qual o Poder Público, nesse caso, qualquer dos entes federativos $^{180}$, atua diretamente com os oficiais de cartório para averbar na matrícula dos imóveis já ocupados por população de baixa renda, sua destinação voltada à realização de projetos de regularização fundiária de interesse social. ${ }^{181} \mathrm{~A}$ finalidade do procedimento não se encerra nesse ato, na medida em que, após a demarcação urbanística, a legislação prevê ações encadeadas tanto no sentido de legitimar a posse, instrumento a ser analisado

\footnotetext{
180 Destaca-se, porém, que os imóveis da União apenas podem ser demarcados por ela própria como decorrência do disposto no art. 56, $\S 4^{\circ}$ da Lei ${ }^{\circ} 11.977 / 2009$ e das normas federais de demarcação de terras da União, em especial o Decreto-Lei 9.760/1946.

${ }^{181}$ O Ministério Público questionou a ausência do judiciário no processo de regularização inaugurado pela Lei $\mathrm{n}^{0} 11.977 / 2009$, mas a legalidade do procedimento foi confirmada pelo acórdão Tribunal de Justiça do Estado de São Paulo (Apelação Cível 3529-65.2011.8.26.0576). (NALINI, José Renato. Decisão facilita regulamentação fundiária em São Paulo. Disponível em: <http://www.irib.org.br/html/noticias/noticiadetalhe.php?not=1485>. Acesso em: 26 dez. 2012).
} 
na sequência, quanto no sentido de promover a realização do projeto de regularização fundiária previsto no art. 51 da Lei $\mathrm{n}^{\mathrm{o}} 11.977 / 2009^{182}$ e o parcelamento do solo.

No tocante aos imóveis passíveis de demarcação, a lei estabelece que o processo poderá abranger parte ou a totalidade de um ou mais imóveis, de domínio público ou privado, independentemente da situação do registro de tais imóveis ${ }^{183}$, possibilitando, ainda, que incida sobre imóveis localizados em Área de Preservação Permanente (APP), respeitado o disposto no art. $54, \S 1^{\circ}, \S 2^{\circ}$ e $\S 3^{\circ}$ da Lei $n^{\circ} 11.977 / 2009$.

Dando início à análise do procedimento, o art. 56 da Lei n ${ }^{0}$ 11.977/2009 estabelece que o primeiro elemento é a instrução do auto de demarcação urbanística com a seguinte documentação: (i) planta e memorial descritivo da área a ser regularizada, nos quais constem suas medidas perimetrais, área total, confrontantes, coordenadas preferencialmente georreferenciadas dos vértices definidores de seus limites, número das matrículas ou transcrições atingidas, indicação dos proprietários identificados e ocorrência de situações mencionadas no inciso I do $\S 5^{\circ}$; (ii) planta de sobreposição do imóvel demarcado com a situação da área constante do registro de imóveis e, quando possível, com a identificação das situações mencionadas no inciso I do $\S 5^{\circ}$; e (iii) certidão da matrícula ou transcrição da área a ser regularizada, emitida pelo registro de imóveis, ou, diante de sua inexistência, das circunscrições imobiliárias anteriormente competentes.

O procedimento da demarcação urbanística encontra-se disciplinado pelo art. 56 e pode ser dividido em duas grandes esferas: (i) as etapas que envolvem apenas os órgãos responsáveis pela gestão patrimonial dos entes federados, e (ii) as etapas que ocorrem no registro de imóveis.

Antes de o processo ser iniciado no registro de imóveis, a legislação prevê as seguintes etapas: (i) notificação dos órgãos responsáveis pela administração patrimonial

\footnotetext{
182 “Art. 51. O projeto de regularização fundiária deverá definir, no mínimo, os seguintes elementos: I - as áreas ou lotes a serem regularizados e, se houver necessidade, as edificações que serão relocadas; II - as vias de circulação existentes ou projetadas e, se possível, as outras áreas destinadas a uso público; III - as medidas necessárias para a promoção da sustentabilidade urbanística, social e ambiental da área ocupada, incluindo as compensações urbanísticas e ambientais previstas em lei; IV - as condições para promover a segurança da população em situações de risco, considerado o disposto no parágrafo único do art. $3^{\circ}$ da Lei ${ }^{\circ}$ 6.766, de 19 de dezembro de 1979; e V - as medidas previstas para adequação da infraestrutura básica." (Lei $\left.\mathrm{n}^{\mathrm{o}} 11.977 / 2009\right)$.

${ }^{183}$ Diz-se independentemente da situação registral, tendo em vista que o art. 56, § $5^{\circ}$ da Lei ${ }^{\circ}$ 11.977/2009 estabelece que são passíveis de demarcação urbanística os seguintes imóveis: (i) de domínio privado com proprietários não identificados, em razão de descrições imprecisas dos registros anteriores; (ii) de domínio privado objeto do devido registro no registro de imóveis competente, ainda que de proprietários distintos; ou (iii) domínio público.
} 
dos demais entes federados; (ii) prazo de 30 (trinta) dias para manifestação acerca: (a) da anuência ou oposição ao procedimento, na hipótese de a área a ser demarcada abranger imóvel público, (b) dos limites definidos no auto de demarcação urbanística, na hipótese de a área a ser demarcada confrontar com imóvel público; e (c) eventual titularidade pública da área, na hipótese de inexistência de registro anterior ou de impossibilidade de identificação dos proprietários em razão de imprecisão dos registros existentes.

O procedimento seguirá, por meio do encaminhamento do auto de demarcação para o registro de imóveis, nas hipóteses de anuência expressa, envolvendo ou não a realização de ajustes no auto de demarcação, ou tácita, decorridos os 30 (trinta) dias.

Encaminhado o auto de demarcação urbanística ao registro de imóveis, o processo passa pelas seguintes fases: (i) identificação do proprietário da área a ser regularizada e de matrículas ou transcrições que a tenham por objeto; (ii) notificação do proprietário e dos confrontantes da área demarcada ${ }^{184}$ para, querendo, apresentarem impugnação à averbação da demarcação urbanística, no prazo de 15 (quinze) dias; (iii) se os proprietários não forem localizados nos endereços constantes do registro de imóveis ou naqueles fornecidos pelo poder público, o poder público que realizar a demarcação deverá notificar, por edital, eventuais interessados, bem como o proprietário e os confrontantes da área demarcada ${ }^{185}$; (iii) decorrido o prazo sem impugnação, a demarcação urbanística será averbada; (iv) havendo impugnação, o oficial do registro de imóveis deverá notificar o poder público para que se manifeste no prazo de 60 (sessenta) dias, sendo possível propor a alteração do auto de demarcação urbanística ou adotar qualquer outra medida que possa afastar a oposição do proprietário ou dos confrontantes à regularização da área ocupada; (v) tentativa de acordo entre o impugnante e o poder público, promovida pelo oficial de registro.

Se, ao final do procedimento, não houver acordo entre o impugnante e o poder público, a legislação estabelece que a demarcação urbanística será encerrada em relação à área impugnada. Representando a área impugnada apenas uma parcela da área objeto do auto de demarcação urbanística, o procedimento seguirá em relação à parcela não impugnada.

\footnotetext{
${ }^{184}$ A notificação dar-se-á pessoalmente ou pelo correio, com aviso de recebimento, ou, ainda, por solicitação ao oficial de registro de títulos e documentos da comarca da situação do imóvel ou do domicílio de quem deva recebê-la.

185 São requisitos para a notificação por edital: I - resumo do auto de demarcação urbanística, com a descrição que permita a identificação da área a ser demarcada e seu desenho simplificado; II - publicação do edital, no prazo máximo de 60 (sessenta) dias, uma vez pela imprensa oficial e uma vez em jornal de grande circulação local; e III - determinação do prazo de 15 (quinze) dias para apresentação de impugnação à averbação da demarcação urbanística. (art. 56, $\S 3^{\circ}$ da Lei n ${ }^{\circ} 11.977 / 2009$ )
} 
Realizada a averbação do auto de demarcação urbanística, o Poder Público dará seguimento à regularização fundiária de interesse social, elaborando o projeto previsto no art. 51 da Lei $\mathrm{n}^{0}$ 11.977/2009 e submetendo a registro o parcelamento dele decorrente, ato que permitirá a concessão de título de legitimação de posse e posterior conversão em propriedade, quando aplicável. Segundo o disposto no art. 68 da Lei n ${ }^{0} 11.977 / 2009$, não serão cobradas custas e emolumentos para o registro do auto de demarcação urbanística, do título de legitimação e de sua conversão em título de propriedade e dos parcelamentos oriundos da regularização fundiária de interesse social.

Alguns aspectos merecem considerações. Primeiramente, é notória tentativa de simplificação do processo de regularização fundiária de interesse social nos casos de ocupações já consolidadas, principalmente pela ausência, a priori, de participação do poder judiciário em relação às etapas do processo que envolvem a de regularização dominial.

Além disso, cumpre salientar que se trata de instrumento jurídico de intervenção na propriedade que se opera sem o pagamento de qualquer indenização. Isso por duas razões centrais que nos parecem razoáveis: (i) ou o proprietário do imóvel apresentou-se de maneira diligente e, nessa hipótese, a demarcação somente ocorrerá com a sua concordância; (ii) ou o proprietário logrou-se omisso em relação a sua propriedade e não se manifestou no processo de demarcação, que acabará por ocorrer sem sua concordância.

Nesse último caso, é evidente que a lei cuidou de tratar de situações já consolidadas em que, muitas vezes, o próprio proprietário tem interesse em que haja alteração do domínio, ou, ainda, são situações em que sequer é possível identificar o proprietário do imóvel.

\subsubsection{Legitimação da posse}

A opção pelo exame do instituto da legitimação da posse como parte integrante da demarcação urbanística justifica-se, já que é etapa seguinte ao registro do parcelamento decorrente do projeto de regularização fundiária de interesse social. Conforme se depreende da definição exarada no art. 47, inciso IV da Lei n ${ }^{0}$ 11.977/2009, a legitimação da posse é um ato do poder público, registrado em cartório, destinado a conferir título de reconhecimento de posse, em relação aos imóveis que sejam objeto de demarcação urbanística, para a identificação do ocupante e do tempo e natureza da posse ali exercida.

Apresenta-se como requisito para a legitimação da posse, além da demarcação 
urbanística, a realização, pelo Poder Público, do cadastro dos moradores ${ }^{186}$, sempre que estes: (i) não forem concessionários, foreiros ou proprietários de outro imóvel urbano ou rural; e (ii) não forem beneficiários de legitimação de posse concedida anteriormente. $\mathrm{O}$ título de legitimação de posse poderá ser extinto pelo Poder Público que o emitiu quando houver constatação no sentido de que o beneficiário não está na posse do imóvel e não registrou a cessão desse direito.

Conforme dispõe o art. $58, \S 2^{\circ}$ e $\S 3^{\circ}$, da Lei $n^{\circ} 11.977 / 2009$, o título de legitimação será concedido preferencialmente em nome da mulher, será registrado na matrícula do imóvel e não será concedido aos ocupantes que forem realocados em razão da implementação do projeto de regularização fundiária de interesse social, permanecendo, nesse caso, o dever do Poder Público assegurar-lhes o direito à moradia em outro local.

Apesar de a legislação possibilitar a aplicação do instituto tanto para imóveis públicos quanto para imóveis privados, prevendo indistintamente que o título devidamente registrado constitui direito em favor do detentor da posse direta para fins de moradia, a maior novidade apresenta-se quando o imóvel é privado.

Isso porque, quando o imóvel é público, a legitimação da posse se apresenta como mais uma das alternativas que o Poder Público tem para regularizar áreas públicas, nesse caso, gratuita e passível de cessão, desde que registrada, sob pena de extinção do título.

Por outro lado, sendo o imóvel privado, o art. 60 da Lei $n^{\circ} 11.977 / 2009$ prevê a possibilidade de administrativamente ocorrer a conversão do título de legitimação da posse em propriedade, decorridos 5 (cinco) anos de seu registro. Para tanto, o detentor do título de legitimação da posse deve apresentar os seguintes documentos no cartório de registro: (i) certidões do cartório distribuidor demonstrando a inexistência de ações em andamento que versem sobre a posse ou a propriedade do imóvel; (ii) declaração de que não possui outro imóvel urbano ou rural; (iii) declaração de que o imóvel é utilizado para sua moradia ou de sua família; e (iv) declaração de que não teve reconhecido anteriormente o direito à usucapião de imóveis em áreas urbanas.

Nota-se que tais documentos têm a finalidade de demonstrar o cumprimento dos seguintes requisitos, respectivamente: (i) o exercício da posse sem qualquer oposição; (ii) a inexistência de título de propriedade de outro imóvel urbano ou rural; (iii) a utilização do

\footnotetext{
186 “Art. 59, § $2^{\circ}$ A legitimação de posse também será concedida ao coproprietário da gleba, titular de cotas ou frações ideais, devidamente cadastrado pelo poder público, desde que exerça seu direito de propriedade em um lote individualizado e identificado no parcelamento registrado." (Lei n $11.977 / 2009)$.
} 
imóvel para fins de moradia; e (iv) o detentor do título de legitimação não ter tido reconhecido o direito à usucapião de imóveis em áreas urbanas.

Importa destacar, ainda, que tais requisitos são aplicáveis apenas no caso da área a que corresponde o título de legitimação ser inferior a $250 \mathrm{~m}^{2}$ (duzentos e cinquenta metros quadrados), aproximando o procedimento administrativo aos requisitos para a aquisição da propriedade por usucapião especial urbana. ${ }^{187}$ Tendo o lote área superior aos $250 \mathrm{~m}^{2}$ (duzentos e cinquenta metros quadrados), a lei estabelece a aplicabilidade dos prazos relativos a outras modalidades de usucapião.

Fica evidenciado que a possibilidade de conversão do título de legitimação da posse em propriedade se apresenta como uma forma de alteração no domínio do imóvel por processo administrativo, e, por essa razão, tem sido identificada como usucapião especial urbana extrajudicial.

\subsubsection{Direito de superfície}

O direito de superfície, que tem origem no Direito Romano, encontra-se previsto no Estatuto da Cidade como instrumento jurídico da política urbana, no artigo $4^{\mathrm{o}}$ e artigos 21 a 24, e no Código Civil ${ }^{188}$, artigos 1.369 a 1.377. À semelhança de outros institutos já analisados, como a CDRU e a CUEFM, o mecanismo tem a finalidade de atribuir direitos reais de usar, fruir e dispor ${ }^{189}$ à pessoa diversa do proprietário do imóvel, público ou privado. José Afonso da SILVA pontua que o instrumento:

[...] serve para favorecer a construção de edifícios sobre terrenos pertencentes a pessoa privada (ou pública) que, de um lado, não pretende aliená-lo e, de outro, não quer ou não tem possibilidade econômica de construir nele e nem deseja utilizá-lo de outro modo. ${ }^{190}$

A aplicabilidade do direito de superfície em processos de regularização fundiária é

\footnotetext{
${ }^{187}$ Art. 183 da Constituição Federal e art. $9^{\circ}$ do Estatuto da Cidade.

188 Apesar da previsão no Código Civil, importa esclarecer que não caberá ao presente tópico a análise comparativa do direito de superfície previsto no Código Civil e no Estatuto da Cidade, mas tão somente apresentar os dispositivos que possam sanar eventuais omissões acerca do tratamento do instituto dado pelo Estatuto da Cidade.

${ }^{189}$ Aqui, como bem ressalta Fernando Dias Menezes de Almeida, a alienação não envolve a propriedade em si, já que o superficiário não a detém, mas sim do próprio direito de superfície (ALMEIDA, Fernando Dias Menezes de. Dos instrumentos em geral. Do direito de superfície. In: ALMEIDA, Fernando Dias Menezes de; MEDAUAR, Odete (coord.). Estatuto da Cidade - Lei no 10.527, de 10.07.2001: Comentários. 2. ed. São Paulo: Revista dos Tribunais Ltda., 2004, p. 171).

${ }^{190}$ SILVA, op. cit, 1981, p. 532.
} 
evidente, tendo em vista que além de possibilitar a formalização do exercício do domínio útil, desde que esteja sendo exercido irregularmente, pode favorecer a construção de equipamentos públicos, edifícios e conjuntos habitacionais em terrenos que não tenham destinação na cidade. ${ }^{191}$

Segundo o disposto no do Estatuto da Cidade, o direito de superfície pode ser concedido, gratuitamente ou onerosamente, por tempo determinado ou indeterminado, mediante escritura pública registrada no cartório de registro de imóveis. Percebe-se que, apesar da possibilidade do direito ser transmitido por tempo indeterminado, não se trata de uma contratualização perpétua, como ocorre na enfiteuse, que apenas se extingue nas hipóteses de descumprimento das obrigações pecuniárias assumidas. A ausência de fixação de prazo apenas denota a possibilidade de denúncia unilateral. Entretanto, inexistindo regra específica acerca da operacionalização prática dessa denúncia unilateral na lei, caberia ao contrato estabelecer e, em última instância, aplicar-se-iam analogamente as regras que regem o comodato e a locação. ${ }^{192}$

O contrato que transfere direito sobre a superfície de imóvel por estabelecer sua abrangência à utilização do solo, subsolo ou espaço aéreo relativo ao terreno, atendida legislação urbanística e aos dispositivos constitucionais que regulam o uso do subsolo (art. 20, incisos IX e X, e 176 da CF).

Os encargo e tributos que incidirem sobre a propriedade superficiária serão integralmente de responsabilidade do superficiário que estará, ainda, obrigado, proporcionalmente à sua parcela de ocupação efetiva, a arcar com os encargos e tributos sobre a área objeto da concessão do direito de superfície, salvo disposição em contrário do contrato respectivo em relação a este último aspecto. ${ }^{193}$ Isso significa afirmar que, independentemente de pactuação contratual acerca da obrigação de pagamento dos encargos e tributos:

[...] o superficiário restará como responsável pela integralidade dos encargos e tributos que incidirem sobre a propriedade superficiária, ou seja, por eles poderá ser demandado caso não pagos por quem seja obrigado a tanto (o proprietário ou superficiário mesmo). ${ }^{194}$

A possibilidade do direito de superfície ser transferido a terceiros poderá ser objeto

\footnotetext{
${ }^{191}$ SAULE JUNIOR, op. cit., 2004, p. 521.

192 ALMEIDA, op. cit., 2004, p. 172.

${ }^{193}$ Art. $21, \S 3^{\circ}$ do Estatuto da Cidade.

${ }^{194}$ ALMEIDA, op. cit., 2004, p. 176.
} 
de disciplina no contrato, sendo que a transmissão aos herdeiros, no caso de morte do superficiário, já se encontra autorizada na lei e independe de pactuação contratual. ${ }^{195}$ Assim, terão direito de preferência, em igualdade de condições à oferta de terceiros, o superficiário e o proprietário nas hipóteses, respectivamente, de alienação do terreno, ou do direito de superfície. ${ }^{196}$

A extinção do direito de superfície ocorre pelo advento do termo ou pelo descumprimento das obrigações contratuais assumidas pelo superficiário. ${ }^{197} \mathrm{Com}$ isso, o proprietário recupera o pleno domínio do terreno, bem como das acessões e benfeitorias introduzidas no imóvel, independentemente de indenização, se as partes não houverem estipulado o contrário no respectivo contrato. ${ }^{198}$

\subsubsection{Direito de preempção}

O direito de preempção, nos termos do previsto no art. $25, \S 1^{\circ}$ do Estatuto da Cidade, nada mais é do que o estabelecimento do direito de preferência do Poder Público municipal para aquisição de imóvel urbano objeto de alienação onerosa entre particulares. Para tanto, o dispositivo estabelece a necessidade de: (i) haver lei autorizando a utilização do instituto para área já indicada no Plano Diretor como passível de ser sujeita à preempção; e (ii) definição de prazo não superior a cinco anos, independentemente do número de alienações referentes ao mesmo imóvel.

O Estatuto da Cidade cuidou de disciplinar as finalidades para as quais o mecanismo poderia ser utilizado, prevendo que o direito de preempção será exercido sempre que o Poder Público necessitar de áreas para: (i) regularização fundiária; (ii) execução de programas e projetos habitacionais de interesse social; (iii) constituição de reserva fundiária; (iv) ordenamento e direcionamento da expansão urbana; (v) implantação de equipamentos urbanos e comunitários; (vi) criação de espaços públicos de lazer e áreas verdes; (vii) criação de unidades de conservação ou proteção de outras áreas de interesse ambiental; e (viii) proteção de áreas de interesse histórico, cultural ou paisagístico. Assim,

\footnotetext{
195 Art. $21, \S 4^{\mathrm{o}}$ e $\S 5^{\circ}$, do Estatuto da Cidade.

${ }^{196}$ Art. 22 do Estatuto da Cidade.

${ }^{197}$ Art. 23, incisos I e II, do Estatuto da Cidade.

${ }^{198}$ Art. 24 do Estatuto da Cidade.
} 
a lei que autorizar a incidência do direito de preempção deverá enquadrar cada área indicada em uma ou mais das finalidades enumeradas.

Na sequência, o art. 27 e seus parágrafos cuidam tão somente do procedimento a ser adotado pelo proprietário que tem intenção de alienar imóvel compreendido pela área de incidência do direito de preempção. Em relação ao procedimento, cumpre apenas destacar que na hipótese de descumprimento do procedimento, o Município fica autorizado a adquirir o imóvel pelo valor da base de cálculo do IPTU ou pelo valor indicado na proposta apresentada, se este for inferior àquele.

A utilização do instituto em projetos de regularização fundiária urbana de interesse social pode ter os mais variados objetivos, dentre os quais se destacam os seguintes: (i) contribuir para a legalização do domínio da área, com a compra pelo Poder Público e posterior CDRU (ou outro mecanismo) aos ocupantes, na hipótese de já haver ocupação irregular no imóvel; (ii) garantir a ampliação do estoque de áreas públicas a serem destinadas para eventual realocação da população como decorrência da realização de projetos de regularização fundiária; ou, ainda, (iii) destinar imóveis para habitação de interesse social, aumentando a oferta e prevenindo o acesso ilegal do solo urbano. ${ }^{199}$

\subsubsection{Desapropriação}

Antes de dar início, cumpre esclarecer que a finalidade do presente tópico não é discorrer detalhadamente acerca do instituto da desapropriação, típico instrumento do Direito Administrativo, mas tão somente conceituá-lo e buscar aspectos que se relacionam ou que podem se relacionar com processos de regularização fundiária urbana de interesse social.

Situada a escopo da análise, a desapropriação apresenta-se como mecanismo que intervém na propriedade ${ }^{200}$ e é, portanto, concebida como instrumento jurídico que autoriza

\footnotetext{
199 Destaca-se que, no tocante à utilização do instituto em relação à política urbana como um todo, o Ministério das Cidades menciona as seguintes finalidades: "constituir um sistema de informações públicas sobre as alienações voluntárias que se processam no interior de um perímetro urbano estabelecido pelo Município em razão do interesse público ou social, constituir um banco de áreas públicas e controlar os preços dos terrenos, em especial em áreas urbanas cujo preço dos imóveis dos terrenos sejam elevados devido à existência de especulação imobiliária.” (ROLNIK, op. cit., 2002, p. 135).

${ }^{200}$ Nas palavras de José Afonso da SILVA: “A desapropriação atinge caráter de perpetuidade do direito de propriedade, cortando-o coativamente. [...] Quando se diz que restrições são limitações ao caráter absoluto, isso quer manifestar a idéia de que, por elas, os caracteres exclusiva e perpétuo ficam incólumes. Já a servidão atinge o caráter exclusivo, mas, por aí, também toca ao absoluto, mas não alcança o perpétuo. A
} 
o Poder Público a transferir a propriedade de determinado bem, privado ou público ${ }^{201}$, para seu patrimônio ou de seus delegatários ${ }^{202}$, desde que para tanto haja utilidade pública ou interesse social, regulados, respectivamente, pelo Decreto-Lei $n^{0} 3.365 / 1941$ e pela Lei $n^{\circ}$ 4.132/1962, ou importe em sanção por descumprimento da função social, nos termos do art. $182, \S 4^{\circ}$, inciso III da Constituição Federal. A utilização do instituto pressupõe, ainda, o pagamento de prévia e justa indenização em dinheiro, nos dois primeiros casos, e em títulos da dívida pública, no último. ${ }^{203}$

São, portanto, três as modalidades de desapropriação: (i) utilidade pública; (ii) interesse social; e (iii) sanção, como decorrência de exercício da propriedade em descumprimento da função social.

No que se refere às duas primeiras modalidades, importa ressalvar que a identificação da situação concreta da irregularidade da ocupação permitirá a análise acerca da aderência às hipóteses de utilidade pública e de interesse social previstas nas respectivas legislações, sendo que, em ambas as modalidades, são possíveis de identificar circunstâncias que permitem estabelecer correlação com eventuais processos de regularização fundiária urbana de interesse social.

No âmbito do Decreto-Lei $n^{0} 3.365 / 1941$, segundo o disposto no art. $5^{\circ}$, alínea " $i "$, com redação dada pela Lei $n^{0} 9.785 / 1999$, consideram-se casos de utilidade pública a desapropriação que apresenta como finalidade: a abertura, conservação e melhoramento de vias ou logradouros públicos; a execução de planos de urbanização; e o parcelamento do solo, com ou sem edificação, para sua melhor utilização econômica, higiênica ou estética. Ora, a depender do tipo de irregularidade, como favelas, por exemplo, e do plano de intervenção a ser empreendido no local da ocupação, a justificativa pela utilidade pública seria cabível, já que, nesse tipo de local, é comum o processo de regularização fundiária necessitar do parcelamento do solo para individualização dos lotes, abertura de vias para melhorar a circulação dentro ou fora da ocupação etc.

desapropriação corta este, e, por consequência, atinge também ou outros dois." (SILVA, op. cit., 1981, p. 536).

${ }^{201}$ Nesse caso, observa-se a regra constante do art. $2^{\circ} \S 2^{\circ}$ : “Os bens do domínio dos Estados, Municípios, Distrito Federal e Territórios poderão ser desapropriados pela União, e os dos Municípios pelos Estados, mas, em qualquer caso, ao ato deverá preceder autorização legislativa."

${ }^{202}$ Segundo autorização prevista no art. $3^{\circ}$ : "Os concessionários de serviços públicos e os estabelecimentos de caráter público ou que exerçam funções delegadas de poder público poderão promover desapropriações mediante autorização expressa, constante de lei ou contrato."

${ }^{203}$ Art. art. $5^{\circ}$, inciso XXIV da Constituição Federal. 
No que toca à desapropriação por interesse social, há previsão mais aderente aos processos de regularização fundiária urbana de interesse social, conforme se depreende da análise do artigo $2^{\circ}$, incisos IV e V da Lei $n^{\circ} 4.132 / 1962$, que estabelecem como escopo dessa modalidade expropriatória: (i) a manutenção de posseiros em terrenos urbanos onde, com a tolerância expressa ou tácita do proprietário, tenham construído sua habilitação, formando núcleos residenciais de mais de 10 (dez) famílias; e (ii) a construção de casas populares.

A desapropriação é iniciada pela edição de decreto expropriatório, podendo excepcionalmente ser declarada por $1 \mathrm{ei}^{204}$, e deve prever a finalidade da medida, sendo que seu descumprimento pode ensejar a retrocessão (retorno do bem ao expropriado), exceto no caso de imóveis desapropriados para implantação de parcelamento popular, destinado às classes de menor renda (art. $5^{\circ} \S 3^{\circ}$ do Decreto-Lei ${ }^{0} 3.365 / 1941$ ), já que, nesse caso, a finalidade que justifica a desapropriação é justamente sua destinação à população de baixa renda.

Poucas são as diferenças entre ambas as formas de desapropriação ${ }^{205}$, já que o Decreto-Lei $\mathrm{n}^{\circ} 3.365 / 1941$ também se aplica à desapropriação por interesse social nos casos em que a Lei $n^{0} 4.132 / 1962$ for omissa ou naquilo que regular o processo da desapropriação e a justa indenização devida ao proprietário.

Aspecto relevante para a presente análise refere-se à questão da necessidade de pagamento de justa indenização em dinheiro. Segundo Fernando Dias Menezes de Almeida: "consolidou-se o entendimento dos intérpretes no sentido de que a justiça da indenização está relacionada a sua identificação com o efetivo valor de mercado do bem. Dai por que falar que a indenização deve corresponder ao valor real do imóvel.",206

Independentemente do valor a ser pago pelo Poder Público, importa destacar que esse mecanismo envolve a alocação de recursos públicos antes mesmo do início das intervenções urbanísticas. Ao considerar, assim, o exame dos demais instrumentos, voltados aos processos de regularização fundiária urbana de interesse social já discutidos nesta pesquisa, é possível constatar que existem diversas alternativas outras que importam em transferência de direitos reais e a aquisição de propriedades desvinculadas do

\footnotetext{
${ }^{204}$ Art. $8^{\circ}$ O Poder Legislativo poderá tomar a iniciativa da desapropriação, cumprindo, nesse caso, ao Executivo, praticar os atos necessários à sua efetivação." (Decreto-Lei n ${ }^{\circ} 3.3 .65 / 1941$ ).

${ }^{205}$ Além das hipóteses de configuração de uma ou de outra modalidade, destaca-se que o prazo para dar início aos atos executórios da desapropriação são diversos. Na desapropriação por utilidade pública, o Poder Público tem 5 (cinco) anos para efetivar o ato expropriatório, mediante acordo ou judicialmente, dando início às providências de aproveitamento do bem expropriado, sendo que, na desapropriação por interesse social, o prazo é de 2 (dois) anos.

${ }^{206}$ ALMEIDA, op. cit., 2004, p. 104.
} 
pagamento prévio de qualquer valor.

A imperatividade de a Administração Pública atuar de modo eficiente e econômico impede que a desapropriação seja o principal mecanismo a ser utilizado para a realização de processos de regularização fundiária urbana de interesse social, tendo, portanto, uma aplicação subsidiária.

Antes, portanto, de dar início ao processo de desapropriação por utilidade pública ou interesse social, sugere-se a observância dos seguintes critérios: (i) verificar se a população preenche os requisitos para o reconhecimento da aquisição da propriedade por usucapião, individual ou coletiva, ou para o direito à CUEFM, no caso de desapropriação entre entes da federação; (ii) caso o terreno seja público, respeitada a regra da desapropriação entre entes federativos, verificar se não há interesse do ente que detém o domínio em promover a regularização fundiária de interesse social por meio da CDRU; e (iii) dar início ao processo de demarcação urbanística e de legitimação da posse, que pode implicar a conversão da posse em propriedade, no caso de imóveis públicos, sem que isso provoque dispêndio de recursos já no início do processo de titulação.

\subsubsection{Desapropriação sanção}

A desapropriação sanção se difere das demais principalmente por seu caráter de penalização do proprietário e por ser de exclusividade do Município, diante da especificidade do procedimento que culmina na utilização do instituto. Prevista no art. 182, $\S 4^{\circ}$, inciso III da Constituição Federal, e no art. $8^{\circ}$ da Lei federal $n^{\circ} 10.257 / 2001$ - Estatuto da Cidade, sua utilização acaba por sancionar o proprietário de imóvel urbano que deixa de dar a devida função social ao bem, à medida que estabelece o pagamento em títulos da dívida pública resgatáveis no prazo de até dez anos.

Nota-se que dois são os aspectos centrais para a compreensão do instrumento. $\mathrm{O}$ primeiro refere-se à análise das hipóteses de incidência que não pode olvidar do tratamento do conteúdo de função social a ser extraída do dispositivo constitucional. A segunda relaciona-se com as características da indenização e em que medida ela se diferencia daquela abordada na desapropriação por utilidade pública ou interesse social.

$\mathrm{O}$ art. $182, \S 4^{\circ}$ da Constituição Federal estabelece que lei municipal específica para área incluída no Plano Diretor pode prever a aplicação ao proprietário de imóvel urbano 
não edificado, subutilizado ou não utilizado, de acordo com as seguintes medidas sucessivas: (i) parcelamento ou edificação compulsórios; (ii) IPTU progressivo no tempo; e (iii) desapropriação sanção.

Partindo da premissa já detalhada no tópico que analisou a relação entre regularização fundiária urbana de interesse social e a função social da propriedade urbana, os conceitos dos termos "não edificado", "subutilizado" ou "não utilizado" são diferentes e compreendem, respectivamente, o solo que não é ocupado por nenhuma edificação; o imóvel que apresenta coeficiente ou índice de aproveitamento e taxa de ocupação inferiores ao exigido no Plano Diretor; e o uso ou destinação incompatível com o Plano Diretor.

Por tal razão, o Estatuto da Cidade no caput de seu art. $5^{\circ}$ cuidou de incluir, além do parcelamento e edificação compulsórios, já previstos no inciso I do $\S 4^{\circ}$ do art. 182 da Constituição Federal, a utilização compulsória ${ }^{207}$ como etapa inicial das medidas que podem culminar na desapropriação.

Depois de notificado, o proprietário passa a ter prazo, que não pode ser inferior a um ano, para dar o devido aproveitamento ao imóvel. Descumpridas as condições ou prazos da notificação, o Município fica autorizado a dar início à cobrança do IPTU progressivo do tempo (art. $7^{\circ}$ do Estatuto da Cidade). Decorridos 5 (cinco) anos de cobrança do IPTU progressivo, sem que o proprietário tenha cumprido a obrigação de parcelamento, edificação ou utilização, o Município poderá proceder à desapropriação do imóvel, com pagamento em títulos da dívida pública (art. $8^{\circ}$ do Estatuto da Cidade), sendo, portanto, uma decisão discricionária do Município.

Apesar de discricionária, contudo, não parece que tal discricionariedade possa implicar ausência perpétua de providências no sentido de dar ao imóvel sua devida função social. Ainda que a cobrança do IPTU progressivo no tempo seja uma medida confortável para o Município, já que recebe um valor mais elevado e não precisa empreender recursos, a aplicação da medida tributária não tem o condão de dar ao imóvel o adequado aproveitamento.

Ainda que a Constituição Federal em seu art. $182, \S 4^{\circ}$ tenha facultado ao Poder Público municipal a edição de lei específica destinada a obrigar o proprietário a promover o adequado aproveitamento do imóvel nas hipóteses de solo urbano não edificado, subutilizado ou não utilizado, entendemos que, uma vez editada a lei municipal tratando

\footnotetext{
${ }^{207}$ Não há, no nosso entender, inconstitucionalidade dessa medida tendo em vista que o próprio caput do art. 182 delega à lei a expedição de diretrizes gerais de execução da política urbana e, ainda, ao plano diretor o conteúdo da função social da propriedade.
} 
dos imóveis sem aproveitamento adequado, não caberia alegar discricionariedade em relação à aplicação de sanções. Isso porque, a faculdade constitucionalmente garantida relaciona-se apenas com a edição da lei, diante das diferentes situações concretas vivenciadas pelos Municípios brasileiros. Tendo sido editada a lei e concretizada a hipótese de incidência que dá fundamento à aplicação da sanção, não há margem de discricionariedade à Administração Pública para deixar de aplicá-la. ${ }^{208} \mathrm{O}$ contrário seria reconhecer de duas uma: (i) ou a irrelevância da norma que dá fundamento á sanção; (ii) a existência de exceções à aplicação da norma verificadas em concreto sem respaldo legal.

A primeira característica que diferencia essa modalidade das demais desapropriações está na forma de indenização. Nos termos do previsto no art. $8^{\circ}, \S^{\circ}$ do Estatuto da Cidade, o pagamento se dará com títulos da dívida pública, que tenham prévia aprovação pelo Senado Federal, ${ }^{209}$ resgatáveis no prazo de até dez anos, em prestações anuais, iguais e sucessivas, assegurados: (i) o valor real da indenização e (ii) os juros legais de $6 \%$ (seis por cento) ao ano ${ }^{210}$, decorrentes do pagamento dos títulos em parcelas.

No tocante ao valor real da indenização, o Estatuto da Cidade estabelece as seguintes regras: (i) refletirá o valor da base de cálculo do IPTU, descontado o montante incorporado em função de obras realizadas pelo Poder Público na área onde o mesmo se localiza após a notificação de que trata o $\S 2^{\circ}$ do art. $5^{\circ}$ dessa Lei; e (ii) não computará expectativas de ganhos, lucros cessantes e juros compensatórios.

Acerca do primeiro aspecto, entendemos que a menção à utilização da base de cálculo do IPTU se caracteriza como mera referência para a definição do valor a ser pago a título de indenização. ${ }^{211} \mathrm{O}$ desconto previsto no dispositivo indica a tentativa de retirar do

\footnotetext{
${ }^{208}$ Nessa abordagem semelhante, Ricardo P. Paes Kim afirma: "Com efeito, o art. 182, §4 $4^{\circ}$ da Constituição prevê as penalidades que deverão ser aplicadas, de forma sucessiva, aos proprietários que não atenderem às exigências do Plano Diretor, ou seja, fixa sanções que necessariamente deverão ser aplicadas, de forma protestativa. A lei não deixou margem ao administrador um campo de liberdade para a aplicação dessas sanções.” (Desapropriação-sanção urbanística no Estatuto da Cidade. In: FINK, Daniel Roberto (coord.). Temas de Direito Urbanístico 4, São Paulo: Centro de Apoio Operacional de urbanismo e Meio Ambiente, Ministério Público do Estado de São Paulo e Imprensa Oficial, 2005, p.145).

${ }^{209} \mathrm{O}$ condicionamento da emissão do título à aprovação do Senado Federal pode culminar na impossibilidade do Município desapropriar o bem. Nesse caso, seguirá o Município cobrando o IPTU progressivo no tempo, já que esse valor é devido até a imissão na posse do imóvel e tal imissão, por analogia ao previsto no art. 15, $\S 1^{\circ}$ Decreto-Lei $n^{\circ} 3.3 .65 / 1941$, ocorre apenas após o depósito do valor. (ALMEIDA, op. cit., p. 103).

210 "Tais juros não se confundem com os juros moratórios nem os juros compensatórios incidentes no pagamento das desapropriações em geral”. (ALMEIDA, op. cit., p. 101).

211 "Refletir não significa ser idêntico. Se quisesse tal consequência, o legislador teria sido explícito. E se assim o fizesse, incidiria em inconstitucionalidade, evidentemente alterando o sentido de valor justo, real, pois é notório que o valor venal arbitrado para fins de IPTU nem sempre corresponde à realidade de mercado. Essa defasagem, aliás, não pode ser imputada ao proprietário, já que o valor é fixado pelo Poder Público.
} 
valor a ser pago a título de indenização a mais-valia incorporada com a execução de obras públicas, em relação às quais o proprietário não contribuiu diretamente, mas poderia ter usufruído se tivesse optado por vendê-lo antes dos cinco anos de cobrança do IPTU progressivo. ${ }^{212}$ No que toca ao critério da ausência de incorporação das expectativas de ganhos, lucros cessantes e juros compensatórios, cumpre, apenas, destacar que são medidas condizentes com o caráter sancionatório da desapropriação em análise.

O Estatuto da Cidade estabelece, ainda, nos últimos parágrafos do art. $8^{\mathrm{o}}$, a obrigatoriedade de o Município proceder ao adequado aproveitamento, diretamente ou por meio de terceiros, do imóvel no prazo máximo de cinco anos, contado a partir da sua incorporação ao patrimônio público.

Diante dos delineamentos apontados, algumas conclusões são possíveis: (i) apesar da decisão acerca da desapropriação sanção ser discricionária, o IPTU progressivo não pode ser perpétuo, à medida que o Município é responsável por zelar para que a cidade cumpra sua função social; e (ii) ainda que a desapropriação sanção também implique dispêndio de recursos públicos, tendo havido recebimento de recursos além do comum, decorrente do IPTU progressivo no tempo, trata-se de opção mais vantajosa ao Município.

\subsection{Peculiaridades dos processos de regularização fundiária urbana de interesse social em Áreas de Preservação Permanente - APP}

De início, enfatiza-se que a análise desenvolvida no presente tópico não se dará nos moldes realizados até aqui, tendo em vista que a finalidade não está restrita ao exame dos instrumentos aplicáveis, mas pretende abranger de modo mais geral as especificidades que envolvem os processos de regularização fundiária urbana de interesse social quando diante de ocupações inseridas em Áreas de Preservação Permanente - APP.

Nota-se que, conforme demonstrado no histórico de formação das cidades

Desta última afirmação se extrai até mais um argumento: sustentar que o valor da indenização seja exatamente o valor da base de cálculo do IPTU seria o mesmo que sustentar que cabe ao poder expropriante definir unilateralmente quanto vai pagar pela desapropriação.” (ALMEIDA, op. cit., p. 105).

${ }^{212}$ Destaca-se que essa operação no sentido de buscar retirar do valor da indenização a mais-valia gerada pelos investimentos públicos, dos quais o proprietário não contribuiu diretamente e que nas cidades se torna ainda mais relevante, não é recente. A análise da desapropriação urbanística por José Afonso da Silva ressalta que "[...] as leis urbanísticas estabelecem critérios especiais para a fixação do justo preço. [...] Mas a preocupação fundamental da legislação estrangeira a esse propósito é de reputar, como preço justo, o valor do imóvel expurgado de plus-valia e de toda forma de especulação.” (SILVA, op. cit., 1981, p 542). 
brasileiras, apresentando sinteticamente no capítulo II desta dissertação, um dado presente nos processos de ocupação irregular foi a expansão das moradias destinadas à população de baixa renda para áreas nas periferias das cidades e em locais inadequados ao uso, onde o mercado imobiliário formal não tinha inserção.

Esse processo de deslocamento para periferias sem que houvesse a provisão de infraestrutura, acabava por representar a ocupação de locais de preservação ambiental, principalmente nos chamados morros ou nos locais próximos aos reservatórios de água, ou seja, em grande medida, justamente a ocupação de APP e, por essa razão, optou-se por abrir um tópico destinado ao tratamento da questão.

O conceito de APP previsto no art. $3^{\circ}$, inciso II da Lei federal $n^{\circ} 12.651 / 2012$ Código Florestal -, indica de modo genérico tratar-se de área protegida, coberta ou não por vegetação nativa, com a função ambiental de preservar os recursos hídricos, a paisagem, a estabilidade geológica e a biodiversidade, facilitar o fluxo gênico de fauna e flora, proteger o solo e assegurar o bem-estar das populações humanas. A delimitação desse conteúdo encontra-se disciplinada no artigo seguinte, que estabelece de modo minucioso as áreas abrangidas no conceito geral apresentado. ${ }^{213}$

Como decorrência da importância de tais áreas para a preservação do meio ambiente, as APPs apresentam um regime de proteção que tem como finalidade a manutenção da vegetação que protege e retarda os processos naturais de erosão,

213 “Art. $4^{\circ}$ Considera-se Área de Preservação Permanente, em zonas rurais ou urbanas, para os efeitos desta Lei: I - as faixas marginais de qualquer curso d'água natural perene e intermitente, excluídos os efêmeros, desde a borda da calha do leito regular, em largura mínima de: a) 30 (trinta) metros, para os cursos d'água de menos de 10 (dez) metros de largura; b) 50 (cinquenta) metros, para os cursos d'água que tenham de 10 (dez) a 50 (cinquenta) metros de largura; c) 100 (cem) metros, para os cursos d'água que tenham de 50 (cinquenta) a 200 (duzentos) metros de largura; d) 200 (duzentos) metros, para os cursos d'água que tenham de 200 (duzentos) a 600 (seiscentos) metros de largura; e) 500 (quinhentos) metros, para os cursos d'água que tenham largura superior a 600 (seiscentos) metros; II - as áreas no entorno dos lagos e lagoas naturais, em faixa com largura mínima de: a) 100 (cem) metros, em zonas rurais, exceto para o corpo d'água com até 20 (vinte) hectares de superfície, cuja faixa marginal será de 50 (cinquenta) metros; b) 30 (trinta) metros, em zonas urbanas; III - as áreas no entorno dos reservatórios d'água artificiais, decorrentes de barramento ou represamento de cursos d'água naturais, na faixa definida na licença ambiental do empreendimento; IV - as áreas no entorno das nascentes e dos olhos d'água perenes, qualquer que seja sua situação topográfica, no raio mínimo de 50 (cinquenta) metros; V - as encostas ou partes destas com declividade superior a $45^{\circ}$, equivalente a $100 \%$ (cem por cento) na linha de maior declive; VI - as restingas, como fixadoras de dunas ou estabilizadoras de mangues; VII - os manguezais, em toda a sua extensão; VIII - as bordas dos tabuleiros ou chapadas, até a linha de ruptura do relevo, em faixa nunca inferior a 100 (cem) metros em projeções horizontais; IX - no topo de morros, montes, montanhas e serras, com altura mínima de 100 (cem) metros e inclinação média maior que $25^{\circ}$, as áreas delimitadas a partir da curva de nível correspondente a $2 / 3$ (dois terços) da altura mínima da elevação sempre em relação à base, sendo esta definida pelo plano horizontal determinado por planície ou espelho d'água adjacente ou, nos relevos ondulados, pela cota do ponto de sela mais próximo da elevação; $X$ - as áreas em altitude superior a 1.800 (mil e oitocentos) metros, qualquer que seja a vegetação; XI - em veredas, a faixa marginal, em projeção horizontal, com largura mínima de 50 (cinquenta) metros, a partir do espaço permanentemente brejoso e encharcado." (Lei federal n 12.651/2012). 
assoreamento etc. Assim, a princípio, a identificação da área como APP importaria na inviabilidade de utilização do local para qualquer finalidade que comprometa sua permanência, incluindo nesse rol o emprego da área para fins de moradia.

Diversas, porém, são as realidades locais e regionais e a situação concreta das APPs apresenta variações, que acabam por inviabilizar a adoção indiscriminada da referida premissa, culminando na inadequação do raciocínio quando assumido de forma absoluta. Seguindo essa lógica, a Lei federal $n^{0}$ 11.977/2009 - Programa Minha Casa, Minha Vida, reconhece a possibilidade de realização de processos de regularização fundiária urbana de interesse social, ainda que a ocupação esteja inserida em APP.

Para tanto, a lei estabelece os seguintes $\operatorname{critérios}^{214}$ : (i) estar a APP inserida em área urbana consolidada $^{215}$; (ii) a APP ter sido ocupada até 31 de dezembro de 2007; e (iii) haver estudo técnico ${ }^{216}$ comprovando que a intervenção para implementação da regularização fundiária de interesse social implica a melhoria das condições ambientais em relação à situação de ocupação irregular anterior.

Além disso, a decisão por efetivar projeto de regularização fundiária de interesse social em APP é, segundo a legislação, discricionária e, como não podia ser diferente, depende de motivação, até para haver controle acerca da medida. Embora a legislação expresse claramente a opção por deixar a cargo da Administração Pública a decisão acerca da efetivação da regularização fundiária de interesse social no local, parece-nos um equívoco tal previsão. Se é requisito para a tomada de decisão a existência de estudo que comprove que a intervenção implica a melhoria das condições ambientais em relação à

\footnotetext{
214 “Art. 54, § $1^{\circ} \mathrm{O}$ Município poderá, por decisão motivada, admitir a regularização fundiária de interesse social em Áreas de Preservação Permanente, ocupadas até 31 de dezembro de 2007 e inseridas em área urbana consolidada, desde que estudo técnico comprove que esta intervenção implica a melhoria das condições ambientais em relação à situação de ocupação irregular anterior." (Lei federal n ${ }^{0}$ 11.977/2009).

215 “Art. 47. Para efeitos da regularização fundiária de assentamentos urbanos, consideram-se:

[...] II - área urbana consolidada: parcela da área urbana com densidade demográfica superior a 50 (cinquenta) habitantes por hectare e malha viária implantada e que tenha, no mínimo, 2 (dois) dos seguintes equipamentos de infraestrutura urbana implantados: a) drenagem de águas pluviais urbanas; b) esgotamento sanitário; c) abastecimento de água potável; d) distribuição de energia elétrica; ou e) limpeza urbana, coleta e manejo de resíduos sólidos;" (Lei federal n ${ }^{\circ} 11.977 / 2009$ ).

216 “Art. 54. $\$ 2^{\circ} \mathrm{O}$ estudo técnico referido no $\S 10$ deverá ser elaborado por profissional legalmente habilitado, compatibilizar-se com o projeto de regularização fundiária e conter, no mínimo, os seguintes elementos: I - caracterização da situação ambiental da área a ser regularizada; II - especificação dos sistemas de saneamento básico; III - proposição de intervenções para o controle de riscos geotécnicos e de inundações; IV - recuperação de áreas degradadas e daquelas não passíveis de regularização; V comprovação da melhoria das condições de sustentabilidade urbano-ambiental, considerados o uso adequado dos recursos hídricos e a proteção das unidades de conservação, quando for o caso; VI - comprovação da melhoria da habitabilidade dos moradores propiciada pela regularização proposta; e VII - garantia de acesso público às praias e aos corpos d'água, quando for o caso." (Lei federal nº 11.977/2009).
} 
situação de ocupação irregular anterior, não nos parece haver margem efetiva para decisão em sentido contrário à intervenção. Se assim não fosse, estaria a Lei a autorizar medida que implicasse piora das condições ambientais na APP.

Mais adequado seria considerar que a discricionariedade estaria relacionada à intenção ou não de regularizar determinada região. Nesse escopo, estaríamos diante de uma discricionariedade muito mais relacionada àquela inserida nas políticas públicas em geral do que uma discricionariedade específica para áreas de APP.

Cabe esclarecer, porém, que a discricionariedade mencionada não se aplica na hipótese da população inserida em APP cumprir os requisitos para a CUEFM. Nesse caso, a discricionariedade estaria na decisão acerca da permanência da população no local gravado como APP ou realocação para outro local. Isso significa que a discricionariedade não se estenderia à conferência ou não do título da CUEFM, até porque, nesse caso, está-se diante de um direito subjetivo da população ao título.

Acerca do ente responsável pela decisão, a princípio, cabe ao Município decidir, nos moldes acima delimitados, acerca da efetivação de projetos de regularização fundiária de interesse social em APP, mas a lei autoriza que tal decisão seja tomada pelo Estado, quando o Município não for competente para o licenciamento ambiental correspondente à área.

Feitos tais esclarecimentos, torna-se evidente que a legislação indica de um lado a possibilidade de reconhecer o direito à permanência da população de baixa renda em APPs já integradas ao tecido urbano, sem deixar de ressaltar que essa medida deve implicar a melhoria das condições ambientais da área ocupada.

\subsection{Síntese conclusiva do capítulo}

A partir da análise realizada neste capítulo é possível apresentar algumas conclusões. Primeiramente, a ampliação do conceito de regularização fundiária urbana de interesse social, compreendendo a legalização do exercício da posse, a alteração de normas urbanísticas voltadas ao parcelamento, uso e ocupação do solo e das edificações, bem como da urbanização, impacta na identificação do rol dos instrumentos aptos a serem instrumentalizados pela Administração Pública em tais processos.

Em segundo lugar, ressalta-se que a etapa de regularização do domínio não 
equivale necessariamente à conferência de título de propriedade, sendo, inclusive, a posse regularizada a melhor opção em áreas públicas, tendo em vista a manutenção do bem no âmbito da gestão pública dos bens para atendimento das finalidades coletivas.

Com relação à regularização do domínio em áreas públicas, constatou-se que a afetação prévia do bem imóvel para a implementação de projetos de regularização fundiária urbana de interesse social evita questionamentos, mas não é o único meio, já que a depender da situação concreta, a afetação tácita pode prevalecer sobre a expressa.

Outro aspecto relevante diz respeito aos institutos aptos a serem utilizados para a regularização dominial: Concessão de Direito Real de Uso, Concessão de Uso Especial para Fins de Moradia, aforamento e doação, nos casos de áreas públicas; e Usucapião Especial Urbana, na hipótese de áreas privadas.

No âmbito da identificação de instrumentos aptos a compatibilizar as ocupações irregulares às normas urbanísticas, destacam-se: as Zonas Especiais de Interesse Social, as Operações Urbanas Consorciadas e o Consórcio Imobiliário.

Como instrumentos que congregam ambas as características foram apresentados os seguintes: Demarcação Urbanística e Legitimação da Posse, Direito de Superfície, Direito de Preempção, Desapropriação e Desapropriação Sanção.

A partir do extenso rol de instrumentos, é possível afirmar que existe um marco legal bastante completo e que busca fornecer mecanismos aptos a se adequarem as mais variadas situações concretas de irregularidade. Adicionalmente, observa-se a necessidade de combinação, sempre que possível, dos instrumentos entre si, já que dificilmente apenas um deles dará conta da complexidade do processo.

Por fim, acerca da regularização fundiária urbana de interesse social em Área de Preservação Permanente, a legislação reconhece a possibilidade de permanência da população de baixa renda em tais áreas quando já integradas ao tecido urbano, sem deixar de ressaltar que tal medida deve implicar a melhoria das condições ambientais da área ocupada. 


\section{CAPÍTULO IV \\ VIABILIZAÇÃO DE INVESTIMENTOS EM PROJETOS DE REGULARIZAÇÃO FUNDIÁRIA URBANA DE INTERESSE SOCIAL}

Um dos aspectos centrais para a realização de projetos de regularização fundiária urbana de interesse social pelo poder público relaciona-se ao tema da viabilização de investimentos a serem alocados para essa finalidade. A relevância da questão não é uma característica exclusiva da regularização fundiária, mas, assim como nas demais áreas que demandam atuação estatal, apresenta-se como elemento essencial para que o instituto seja efetivamente utilizado em sua plenitude.

Compreender a regularização fundiária urbana de interesse social como instrumento que abrange desde a legalização da posse exercida de modo irregular até a urbanização do local ocupado, segundo parâmetros especiais, conforme já tratado anteriormente, representa ampliar consideravelmente os custos financeiros envolvidos nesse processo, já que, em geral, os investimentos relacionados à urbanização são significativamente maiores que os custos financeiros envolvidos apenas em processos de legalização da posse. Adicionalmente, o fato de se tratar de política voltada a atender a população de baixa renda, representa a impossibilidade dos projetos serem autossustentáveis do ponto de vista econômico-financeiro.

O capítulo, assim, cuidará de apresentar alguns dos mecanismos que podem ser utilizados para viabilizar a realização de investimentos necessários em projetos de regularização fundiária urbana de interesse social, buscando identificar alternativas que vão além da forma tradicional de alocação de recursos por meio de dotação orçamentária. ${ }^{217}$

Para tanto, a análise considerará: (i) a aplicação de instrumentos da política urbana que podem servir para viabilizar recursos diretamente em projetos de regularização fundiária; e (ii) o levantamento de alguns instrumentos do direito administrativo que podem

\footnotetext{
${ }^{217}$ Importa destacar que em grande medida ou projetos de regularização fundiária de interesse social contam com financiamento externo, conforme identifica Peter M. WARD ao tratar do tema em relação aos países da América Latina: "Los mecanismos financeiros para la regularización: varios de los más notables y exitosos proyectos dependieron del financiamento externo, y muchos proyectos aparentan acarrear subsidios explícitos e implícitos." (WARD, op. cit., 2007, p. 102).
} 
ser úteis para o atingimento da finalidade pretendida: (a) por possibilitarem o repasse de recursos interfederativos; (b) por permitirem que haja um envolvimento de mais de um ente da Federação na promoção da regularização possibilitando uma repartição dos encargos e custos; e (c) por possibilitarem uma pactuação com a iniciativa privada de longo prazo, que permite congregar diversos escopos, garantindo que determinado escopo economicamente mais vantajoso venha a subsidiar a parcela menos vantajosa economicamente na contratação (como aquela voltada à regularização fundiária de interesse social).

\subsection{Aplicação de instrumentos da política urbana}

A análise empreendida no capítulo anterior identificou os instrumentos da política urbana capazes de serem utilizados em processos de regularização fundiária urbana de interesse social para garantir a legalização da posse, a flexibilização de normas de parcelamento, uso e ocupação do solo e a urbanização dos assentamentos. Entretanto, alguns dos instrumentos, além da finalidade identificada, podem contribuir para viabilizar recursos ou para estimular a realização de investimento diretamente em tais processos.

\subsubsection{Operação urbana consorciada}

A operação urbana consorciada é instrumento jurídico que permite a realização de um conjunto de intervenções e medidas de caráter urbanístico em área específica da cidade com a finalidade de promover transformações urbanísticas estruturais, melhorias sociais e valorização ambiental.

Para tanto, o Estatuto da Cidade estabelece a necessidade de aprovação de lei específica e de elaboração de plano da operação urbana consorciada contendo, dentre outros elementos previstos no art. 33 do Estatuto da Cidade, as contrapartidas que serão exigidas dos proprietários, usuários permanentes e investidores privados em razão da utilização dos benefícios decorrentes da alteração de índices e características do parcelamento, uso e ocupação do solo e subsolo, bem como das normas edilícias, e, ainda, da regularização.

É justamente a possibilidade de fixação de tais contrapartidas que torna a operação urbana consorciada um mecanismo capaz de alavancar recursos para viabilizar o financiamento das mais variadas formas de investimento na área delimitada no plano de 
urbanização, incluindo nesse rol a implementação de projetos voltados à regularização fundiária urbana de interesse social.

As razões que justificam a fixação das contrapartidas e a posterior aplicação dos recursos por ela gerados podem ser extraídas da análise sistemática do Estatuto da Cidade.

No que se refere ao estabelecimento de contrapartidas em operações urbanas consorciadas, duas são as principais razões que o justificam: (i) a necessidade de compensação dos impactos causados em decorrência dos benefícios auferidos aos particulares, já que a alteração de parâmetros urbanísticos importa em realização de investimento na infraestrutura urbana capaz de suportar fisicamente a consequência de tais alterações; e (ii) a recuperação da mais-valia fundiária ${ }^{218}$ gerada, não apenas como decorrência da realização de investimentos públicos na área da operação, mas também das decisões tomadas pelo poder público que acarretem em valorização imobiliária. ${ }^{219}$

Em relação à utilização dos recursos gerados a partir das contrapartidas, o fundamento para sua aplicação pode ser encontrada na necessidade: (i) de financiamento das intervenções públicas no âmbito da operação, bem como (ii) de redistribuição da maisvalia gerada com o instituto. Isso porque a aplicação dos recursos arrecadados com as contrapartidas deve ser orientada tanto no sentido de contribuir para o atingimento da finalidade da própria operação urbana consorciada (promoção de transformações urbanísticas estruturais, melhorias sociais e valorização ambiental), como também para a justa distribuição dos benefícios e ônus decorrentes do processo de urbanização, segundo a diretriz prevista no art. $2^{\circ}$, inciso IX do Estatuto da Cidade.

\footnotetext{
${ }^{218}$ A expressão "mais-valia fundiária" representa os incrementos no valor da terra que são gerados durante as etapas de produção e reprodução no processo de urbanização e podem ocorrer como decorrência do processo de planejamento urbano, incluindo a regulação do uso e ocupação do solo, da realização de investimentos em infraestrutura urbana. (FURTADO, Fernanda. Instrumentos para a gestão social da valorização da terra: fundamentação, caracterização e desafios. In: CESARE, Claudis M. De; CUNHA, Eglaísa Micheline Pontes (coord.). Programa Nacional de Capacitação das Cidades. Financiamento das Cidades: Instrumentos Fiscais e de Política Urbana., Brasília: Ministério das Cidades, 2007, p. 243-244.)

${ }^{219}$ Essa interpretação é possível, tendo em vista que o art. 33, inciso VI do Estatuto da Cidade, prevê apenas a possibilidade de fixação de contrapartida sem vinculá-la, necessariamente, à realização de investimento pelo Poder Público. Nesse sentido, acerca do avanço que as operações urbanas consorciadas trouxeram para o tema da recuperação da mais-valia fundiária, antes centrada apenas no instituto da contribuição de melhoria que se encontra limitado à valorização decorrente de obras públicas e ao valor do investimento da obra, importa destacar o exposto por Betânia de Moraes Alfonsin: "Hoje, no marco de uma operação urbana, é possível recuperar mais-valia de natureza distinta, aquelas que decorrem de tomadas de decisão pelo poder público no processo de Planejamento Urbano, ainda que essas decisões não acarretem qualquer ônus ao poder público. Se das decisões decorrer valorização imobiliária, há autorização legal para recuperação de mais-valias, em notável avanço da legislação brasileira atinente à matéria." (Operações Urbanas Consorciadas como instrumento de captação de mais-valias urbanas: um imperativo da ordem jurídicourbanística brasileira. In: Direito Urbanístico. Estudos Brasileiros e Internacionais. ALFONSIN, Betânia de Moraes e FERNANDES, Edésio, Belo Horizonte: Del Rey, 2006, p. 296.)
} 
Nota-se que não há no Estatuto da Cidade uma prévia definição acerca das formas que as contrapartidas devem assumir, havendo clara margem para que o administrador municipal estabeleça de maneira livre quais as contrapartidas que serão aceitas, desde que preveja tais alternativas no plano da operação. Isso significa afirmar que não há uma determinação legal no sentido de que as contrapartidas devam ser pecuniárias, razão pela qual podem assumir outras formas, como a cessão de terreno, a realização de determinada obra pública etc.

O Estatuto, em seu art. 34, cuidou de identificar tão somente uma das hipóteses que contribui para a arrecadação de recursos pelo poder público municipal: a emissão de quantidade determinada de certificados de potencial adicional de construção - CEPAC, que poderão ser alienados em leilão ou utilizados diretamente no pagamento das obras necessárias à própria operação. ${ }^{220}$

A despeito da possibilidade dos CEPACs serem comercializados no mercado financeiro, sua conversão em solo criado $^{221}$ somente pode ser concretizada na área específica da operação urbana consorciada, ${ }^{222}$ assim como os recursos arrecadados com a emissão de tais títulos também somente podem ser aplicados na área da operação urbana consorciada que deu fundamento a sua emissão. Essa, em verdade, é a orientação para qualquer das contrapartidas arrecadadas pelo Município no âmbito da operação urbana consorciada, tendo em vista o disposto no art. 33, $\S 1^{\circ}$ do Estatuto da Cidade, que estabelece que os recursos auferidos em função das contrapartidas estabelecidas devem ser aplicados exclusivamente na área incluída na operação urbana consorciada.

Ainda que o Estatuto tenha sido expresso em relação ao local de aplicação das contrapartidas, há entendimento no sentido de ser possível o oferecimento de contrapartida fora da área da operação urbana consorciada, no caso da contrapartida ser um bem imóvel de utilização vinculada à promoção de habitação de interesse social ou ao atendimento do

\footnotetext{
${ }^{220}$ O CEPAC, por ser considerado um valor mobiliário, está sujeito é Lei $\mathrm{n}^{\circ} 6.385 / 1976$, bem como à regulamentação da Comissão de Valores Mobiliários, notadamente a Instrução n ${ }^{\circ} 401 / 2003$.

221 Nas palavras de Eros Grau, o instituto do solo criado pode ser definido como: "[...] resultado de construção praticada em volume superior ao permitido nos limites do coeficiente único de aproveitamento. Tudo quanto se construa, pois, além do quantum convencionado em tal coeficiente, inclusive no andar térreo, é entendido como solo criado." (GRAU, op. cit.,1983, p. 57)

${ }^{222}$ Cumpre salientar que sua conversão depende de licença de construção, sendo que o exercício do direito de construir acima do coeficiente de aproveitamento básico deve ser solicitado em concreto, ou seja, em determinado lote no local da operação urbana consorciada.
} 
interesse público. $^{223}$

Entendemos, no entanto, que tal solução seja uma exceção que depende de alguns requisitos, como bem assinala Karlin Olbertz:

[...] a hipótese de oferecimento de contrapartidas na forma de imóveis localizados fora da área da operação é cabível, desde que haja uma relação entre tal contrapartida e as finalidades da operação e desde que haja previsão na lei específica da operação. ${ }^{224}$

Além da observância das mencionadas condicionantes, é necessário verificar se a medida é condizente com a justa distribuição dos benefícios decorrentes do processo de urbanização gerados com a operação urbana consorciada. Reforça-se mais esse aspecto, tendo em vista o histórico relatado anteriormente, no sentido de alijar a população de baixa renda dos benefícios gerados com urbanização. Nessa esfera, estudo desenvolvido por Mariana Fix em relação a duas operações urbanas empreendidas no Município de São Paulo, Água espraiada e Faria Lima, revela como muitas vezes as operações urbanas consorciadas acabam por reforçar processos de segregação sócio-espacial e exclusão territorial da população de baixa renda. ${ }^{225}$

Diante do apresentado, fica evidenciada a possibilidade do instituto alavancar recursos, pecuniários ou não, que possam vir a ser utilizados em processos de regularização fundiária urbana de interesse social na área circunscrita na operação urbana consorciada, sendo, inclusive, um dos caminhos para incluir a população de baixa renda como beneficiária da urbanização decorrente da implementação da operação urbana.

\subsubsection{Outorga onerosa do direito de construir}

A outorga onerosa do direito de construir nada mais é do que a possibilidade de cobrança de contrapartida em função da outorga dos seguintes benefícios ${ }^{226}$ : (i) do direito

\footnotetext{
223 Nesse sentido, conferir: CABRAL, Luciola Maria de Aquino. Operação urbana Consorciada: possibilidades e limitações. In: Revista Magister de Direito Ambiental e Urbanístico, Porto Alegre, n.19, ago./set., 2008, p. 34; e CARVALHO FILHO, José dos Santos. Comentários ao Estatuto da Cidade. 3.ed. rev. ampl. e atual. Rio de janeiro: Lumen Juris, 2009, p. 228. Apud OLBERTZ, Karlin. Operação Urbana Consorciada. Belo Horizonte: Editora Fórum, 2011, p. 115.

${ }^{224}$ OLBERTZ, Karlin. Operação Urbana Consorciada. Belo Horizonte: Editora Fórum, 2011, p. 116.

${ }^{225}$ Parceiros da exclusão: duas histórias da construção de uma nova cidade em São Paulo. Faria Lima e Água espraiada. São Paulo: Boitempo, 2001. Apud ALFONSIN, op. cit., 2006, p. 294.

${ }^{226} \mathrm{O}$ instituto, em verdade, é muito semelhante ao CEPAC, com a diferença de não estar necessariamente vinculado às operações urbanas consorciadas e de não ser securitizado e comercializado no mercado financeiro.
} 
de construir acima do coeficiente de aproveitamento básico adotado para a área em que a propriedade urbana está inserida, podendo o Plano Diretor determinar coeficiente de aproveitamento básico único ou diferenciado para áreas dentro da zona urbana ou, ainda, (ii) de alterar o uso do solo em região também previamente identificada no plano diretor. ${ }^{227}$

Por coeficiente de aproveitamento, entende-se o valor que representa a relação entre a área edificável e a área do terreno, sendo que o plano diretor deverá definir os limites máximos a serem atingidos pelos coeficientes de aproveitamento, considerando a proporcionalidade entre a infraestrutura existente e o aumento de densidade esperado em cada área. $^{228}$

Para a aplicação da outorga onerosa, há necessidade de aprovação de lei específica, que pode ser o próprio Plano Diretor, estabelecendo as seguintes condições mínimas a serem observadas: (i) a fórmula de cálculo para a cobrança; (ii) os casos passíveis de isenção do pagamento da outorga; e (iii) a contrapartida exigida do beneficiário.

No tocante à aplicação dos recursos, o Estatuto não a vincula à área em que o benefício foi concedido, como ocorre no âmbito da operação urbana consorciada, mas estabelece as finalidades que devem ser perseguidas com a utilização dos recursos arrecadados. São elas: (i) regularização fundiária; (ii) execução de programas e projetos habitacionais de interesse social; (iii) constituição de reserva fundiária; (iv) ordenamento e direcionamento da expansão urbana; (v) implantação de equipamentos urbanos e comunitários; (vi) criação de espaços públicos de lazer e áreas verdes; (vii) criação de unidades de conservação ou proteção de outras áreas de interesse ambiental; (viii) proteção de áreas de interesse histórico, cultural ou paisagístico.

Diferentemente da operação urbana consorciada que estabelece finalidades de modo mais abstrato (transformações urbanística, melhorias sociais e valorização ambiental), a opção do legislador no caso da outorga onerosa foi de pré-definir ações determinadas de modo a vincular a administração pública municipal, dentre as quais três

\footnotetext{
227 Desse modo, o Estatuto da Cidade consagrou praticamente todas as alternativas de aplicação do solo criado experimentadas pelas cidades, com exceção das operações interligadas que não vinculavam o solo criado a áreas específicas, podendo ocorrer em qualquer local da cidade, envolviam qualquer alteração de índice, sem limite máximo, e eram solicitadas pelo privado interessado, ou seja, não se inseria em um contexto de planejamento urbano. (ROLNIK, op. cit., 2002, p. 69.)

${ }^{228}$ Nota-se que o Estatuto da Cidade cuidou de vincular o benefício do direito de construir ao coeficiente de aproveitamento básico do imóvel em determinada área, deixando de prever outras alternativas, como, por exemplo, a de estabelecer como critério a densidade básica, como fez o Plano Diretor de Natal, em 1994, que estabeleceu a cobrança do solo criado a partir de densidades superiores a 180 habitante/hectare em área residencial. (ROLNIK, op. cit., 2002, p. 69.)
} 
delas, (i), (ii) e (iii), relacionam-se direta ou indiretamente com o tema da regularização fundiária de interesse social.

Isso garantiu que o impacto causado pela concessão do benefício de construir acima do coeficiente de aproveitamento básico, ou de alterar o uso previamente estabelecido, fosse compensado com a execução de atividades voltadas para a realização de investimento em infraestrutura urbana e em projetos destinados à moradia da população de baixa renda

Além disso, o fato de não ter havido uma vinculação direta entre o local de arrecadação da contrapartida pela outorga do direito de construir e a aplicação dos recursos flexibiliza a escolha acerca da área urbana que merece receber investimentos.

Desse modo, a outorga onerosa do direito de construir representa instituto apto a contribuir para a arrecadação de recursos a serem aplicados em finalidades específicas, dentre as quais se destacam ações relacionadas direta ou indiretamente com a regularização fundiária urbana de interesse social, considerada a circunscrição da área urbana como um todo.

\subsection{Instrumentos do direito administrativo}

Este tópico tem como finalidade indicar alguns instrumentos do direito administrativo que podem ser úteis para a realização de projetos de regularização fundiária urbana de interesse social pelo poder público.

A eleição dos instrumentos teve como fundamento a identificação das alternativas de ajuste capazes de contemplar a regularização fundiária de interesse social em sua plenitude, bem como de viabilizar recursos ou garantir vantagens econômico-financeiras ao ente interessado em dar cabo a projetos de regularização fundiária.

Assim, foram selecionados mecanismos capazes de viabilizar: (i) o repasse interfederativo de recursos; ${ }^{229}$ (ii) a repartição de encargos e custos entre mais de um ente da federação; ou, ainda, (iii) a formalização de parcerias com a iniciativa privada que

\footnotetext{
${ }^{229}$ Foge ao escopo da presente análise o repasse para entidades privadas. Isso porque, ainda que a legislação autorize esse repasse, a intenção do tópico é demonstrar de que forma o poder público pode angariar recursos para implementar projetos de regularização fundiária, ainda que, após a captação de recursos, ele conte com a iniciativa privada para a execução do projeto.
} 
trouxessem vantagens econômico-financeiras para a administração pública, seja pela contratualização de longo prazo, seja pela possibilidade de reunião de diversos escopos, garantindo um subsídio cruzado entre ações mais ou menos vantajosas do ponto de vista econômico, já que a regularização fundiária de interesse social apresenta pequena, ou nenhuma, capacidade de gerar recursos que subsidiem o valor dos investimentos necessários a sua implementação.

\subsubsection{Repasse de recursos}

A opção por tratar das transferências de recursos, notadamente aquelas que ocorrem no âmbito interfederativo, decorre do fato de ser este um importante aspecto da estrutura federativa brasileira, sendo um dos veículos utilizados para organizar a alocação de recursos no sentido de dar cabo à realização de políticas públicas pelos entes de modo articulado.

O repasse pode ocorrer a título voluntário ou compulsório. São voluntárias ${ }^{230}$ as transferências de recursos, correntes ou de capital, ${ }^{231}$ entre entes da Federação, a título de cooperação, auxílio ou assistência financeira, que não decorram de determinação constitucional ou legal. As demais transferências que, portanto, decorrem de determinação constitucional ou legal estão incluídas no rol dos repasses considerados obrigatórios, como, por exemplo, a repartição das receitas tributárias previstas na Seção VI do Capítulo I do Título VI da Constituição Federal.

Para formalizar tais transferências, a legislação apresenta variado rol de instrumentos jurídicos, dentre os quais se destacam o convênio, o contrato de repasse e o termo de compromisso, que, embora semelhantes, apresentam algumas importantes diferenças abaixo apresentadas.

Assim, este tópico apresentará a abordagem do instituto do convênio, tendo em

\footnotetext{
${ }^{230}$ Art. 25 da Lei Complementar $n^{\circ} 101 / 2000$.

231 “Art. 11 - A receita classificar-se-á nas seguintes categorias econômicas: Receitas Correntes e Receitas de Capital. $\S 1^{\circ}$ São Receitas Correntes as receitas tributária, de contribuições, patrimonial, agropecuária, industrial, de serviços e outras e, ainda, as provenientes de recursos financeiros recebidos de outras pessoas de direito público ou privado, quando destinadas a atender despesas classificáveis em Despesas Correntes. $\S 2^{\circ}$ São Receitas de Capital as provenientes da realização de recursos financeiros oriundos de constituição de dívidas; da conversão, em espécie, de bens e direitos; os recursos recebidos de outras pessoas de direito público ou privado, destinados a atender despesas classificáveis em Despesas de Capital e, ainda, o superávit do Orçamento Corrente." (Lei federal n ${ }^{\circ} 4.320 / 1964$ )
} 
vista que, além de ser o tradicional veículo utilizado no âmbito das transferências voluntárias, há possibilidade de aplicação do instituto para diversos escopos; bem como do repasse de recursos no âmbito do Fundo Nacional de Habitação de Interesse Social (FNHIS) que apresenta fonte de financiamento específica para projetos de regularização fundiária urbana de interesse social, a ser formalizada por meio de contrato de repasse, em caráter voluntário, ou termo de compromisso, de modo compulsório.

\subsubsection{Convênios}

O convênio é instituto tradicionalmente utilizado para repasse de recursos. Sua definição encontra-se consolidada na doutrina administrativista, que estabelece o conceito a partir da contraposição entre convênio e contrato. Nesse sentido, reconhece-se o convênio como instrumento jurídico que permite a associação do poder público com entidades públicas ou privadas para a realização de um objetivo de interesse comum, diferentemente dos contratos em que existem interesses contrapostos, como assinala Hely Lopes Meirelles:

Convênio é acordo, mas não é contrato. No contrato as partes têm interesses diversos e opostos; no convênio os partícipes têm interesses comuns e coincidentes. Por outras palavras: no contrato há sempre duas partes (podendo ter mais de dois signatários), uma que pretende o objeto do ajuste (a obra, o serviço, etc.), outra que pretende a contraprestação correspondente (o preço, ou qualquer outra vantagem), diversamente do que ocorre no convênio, em que não há partes, mas unicamente partícipes com as mesmas pretensões. Por essa razão, no convênio a posição jurídica dos signatários é uma só, idêntica para todos, podendo haver apenas diversificação na cooperação de cada um, segundo suas possibilidades para a consecução do objetivo comum, desejado por todos. $^{232}$

Pela definição apresentada, apreende-se que o elemento central a diferenciar a figura do convênio do instituto do contrato administrativo está justamente na relação de cooperação inerente ao convênio que torna inexistente o antagonismo presente nos contratos. $^{233}$ Essa cooperação justifica a aplicabilidade da Lei federal $n^{0}$ 8.666/1993,

\footnotetext{
${ }^{232}$ MEIRELLES, Hely Lopes. Direito Administrativo Brasileiro. 21. ed. São Paulo: Malheiros, 1996, p. 358. 233 Acerca da inconsistência dessa conceituação, valho-me dos ensinamentos de Floriano de Azevedo Marques Neto: "E neste sentido, o entendimento que ora exponho se presta fundamentalmente a gizar que o caráter bilateral, pactual e obrigacional dos convênios (que os faz integrantes da categoria de atos jurídicos de natureza contratual) não os faz confundíveis com os contratos stricto sensu e muito menos os torna espécies
} 
apenas "no que couber", conforme apregoa seu art. $116 .{ }^{234}$ Ainda que a cooperação não seja atributo exclusivo convênios, ${ }^{235}$ embora inerente a este, importa apresentar outras características do convênio, a partir da análise do art. $116, \S 1^{\circ}$ a $\S 6^{\circ}$, da Lei federal $n^{\circ}$ 8.666/1993 deu ao convênio.

Primeiramente, o caput do art. 116 menciona que os convênios podem ser firmados por órgãos e entidades da Administração, abrangendo, portanto, a administração direta e indireta.

Segundo a Lei federal $n^{\circ}$ 8.666/1993, a formalização do convênio depende da apresentação de plano de trabalho pelo interessado contendo, no mínimo, as seguintes informações: (i) identificação do objeto a ser executado; (ii) metas a serem atingidas; (iii) etapas ou fases de execução; (iv) plano de aplicação dos recursos financeiros; (v) cronograma de desembolso; (vi) previsão de início e fim da execução do objeto, bem assim da conclusão das etapas ou fases programadas; (vii) se o ajuste compreender obra ou serviço de engenharia, comprovação de que os recursos próprios para complementar a execução do objeto estão devidamente assegurados, salvo se o custo total do empreendimento recair sobre a entidade ou órgão descentralizador. Nota-se a intenção do legislador em regular os convênios que tenham como finalidade a realização de projetos específicos, sem a delimitação acerca do objeto até para garantir maior flexibilidade para a

de contratos administrativos. Porém, deixa entrever que os convênios estabelecem obrigações para as partes convenentes, obrigações porém que não se fazem uma em relação ou em contra-partida à outra e sim ambas com vistas ao objetivo comum (convenial)." (Os Consórcios Públicos. In: Revista Eletrônica de Direito do Estado, Salvador, Instituto de Direito Público da Bahia, no. 3, julho/agosto/setembro, 2005, p. 21. Disponível em: <http://www.direitodoestado.com.br>. Acesso em: 22 nov. 2012). Seguindo a mesma lógica e reconhecendo o caráter também contratual do convênio, Fernando Dias Menezes de Almeida esclarece: "Ou seja, o convênio é, no Brasil, no mais das vezes, instrumento para criação de situação subjetiva - ainda que envolvendo situações convergentes - e, nesse aspecto, merece receber o tratamento jurídico do contrato (no sentido estrito que lhe dá tradicionalmente a doutrina). " (Contrato Administrativo. São Paulo: Quartier Latin, 2012, p. 243).

${ }^{234}$ Com o intuito de fornecer mais subsídios a justificar a diferença entre convênio e contrato, Maria Sylvia Zanella Di Pietro assevera: "O convênio tem em comum com o contrato o fato de ser um acordo de vontades. Mas é um acordo de vontades com características próprias. Isto resulta da própria Lei $\mathrm{n}^{0} 8.666 / 93$, quando no art. 116, caput, determina que suas normas se aplicam aos convênios 'no que couber'. Se os convênios tivessem natureza contratual, não haveria necessidade dessa norma, porque a aplicação da Lei já decorreria dos artigos $1^{\circ}$ e $2^{\circ}$." (Direito Administrativo. 18. ed. São Paulo: Atlas, 2005, p. 297)

${ }^{235} \mathrm{O}$ tema da cooperação como elemento passível de ser encontrado também nos contratos será mais bem detalhado no tópico dos consórcios públicos, mas cumpre aqui mencionar o entendimento de Marçal Justen Filho: "Mas precisamente e especialmente no âmbito do direito administrativo, trata-se de conjugar a figura do contrato com o postulado do Estado de Direito Democrático. Duas decorrências principais derivarão dessa conjugação. A primeira reside na constatação de que se reserva ao contrato a uma utilização cada vez mais intensa e efetiva. A idéia de um Estado de Direito Democrático tende a reduzir a utilização dos instrumentos jurídicos autorizativos, substituídos por uma atuação de natureza cooperacional." (Curso de Direito Administrativo. 6. ed. Belo Horizonte: Editora Fórum, 2010, p. 437). 
Administração Pública definir. ${ }^{236}$

Após a assinatura do convênio, a entidade ou órgão repassador deverá dar ciência da formalização do ajuste à Assembleia Legislativa ou à Câmara Municipal correspondente.

A forma de colaboração pode se dar de diversos modos: (i) recursos financeiros; (ii) recursos humanos; (iii) uso de equipamentos ou imóveis; etc. No caso de repasse de recursos financeiros, a Lei estabelece a necessidade de o repasse ser efetuado em parcelas e de acordo com o plano de aplicação, previamente aprovado no plano de trabalho. ${ }^{237} \mathrm{~A}$ aplicação dos recursos, em qualquer modalidade, deve ser restrita ao cumprimento do objeto do convênio. Os dispêndios efetuados no âmbito do convênio, bem como eventuais créditos, devem sem comprovados por meio de prestações de contas. ${ }^{238}$

Durante a execução do convênio, os saldos provenientes do ajuste devem ser aplicados em cadernetas de poupança de instituição financeira oficial se a previsão de uso dos recursos for igual ou superior a um mês, ou em fundo de aplicação financeira de curto prazo ou operação de mercado aberto lastreada em títulos da dívida pública, quando a previsão de utilização for menor.

Ao final, quando da conclusão, denúncia, rescisão ou extinção do convênio, os saldos financeiros remanescentes serão devolvidos à entidade ou órgão repassador dos recursos, no prazo improrrogável de 30 (trinta) dias do evento.

\footnotetext{
${ }^{236}$ Não obstante a definição não mencionar a possibilidade de o convênio versar sobre "serviços contínuos", não parece ter excluído essa possibilidade. Nesse sentido, Di Pietro aponta: "É evidente, contudo, que os convênios podem ter por objeto a prestação de serviços contínuos, desde que estejam presentes as características apontadas com relação aos ajustes dessa natureza; nesse caso, o art. 116 será aplicado naquilo que couber.” (DI PIETRO, op. cit., 2005, pp. 299-300). Todavia, ainda que se entenda ser possível a utilização do convênio para formalizar o repasse de recursos que tenha como fundamento a realização de "serviços contínuos", essa alternativa deverá ser implementada apenas na hipótese de inexistir ajuste que melhor formalize a relação que se pretende estabelecer de modo continuado. Isso porque diante do rol de opções que a administração pública faz jus, existem diversos outros mecanismos que podem ser mais adequados a depender da situação concretamente observada.

${ }^{237} \mathrm{Em}$ algumas hipóteses o recurso fica retido. São elas: I - quando não tiver havido comprovação da boa e regular aplicação da parcela anteriormente recebida, na forma da legislação aplicável, inclusive mediante procedimentos de fiscalização local, realizados periodicamente pela entidade ou órgão descentralizador dos recursos ou pelo órgão competente do sistema de controle interno da Administração Pública; II - quando verificado desvio de finalidade na aplicação dos recursos, atrasos não justificados no cumprimento das etapas ou fases programadas, práticas atentatórias aos princípios fundamentais de Administração Pública nas contratações e demais atos praticados na execução do convênio, ou o inadimplemento do executor com relação a outras cláusulas conveniais básicas; III - quando o executor deixar de adotar as medidas saneadoras apontadas pelo partícipe repassador dos recursos ou por integrantes do respectivo sistema de controle interno. (art. 116, $\S 3^{\circ}$, da Lei federal $n^{\circ} 8.666 / 1993$ ).

${ }^{238}$ No âmbito federal, a regulação específica dos convênios firmados com a União encontra-se na Instrução Normativa da Secretaria do Tesouro Nacional n ${ }^{\circ}$ 01/1997.
} 
Nesse ponto, destaca-se o aspecto referente à possibilidade do pacto ser denunciado a qualquer tempo, já que o convênio não é fundado em vínculo contratual. ${ }^{239}$ Nota-se que, sem embargo de ser uma construção doutrinária, não parece ter sido a opção da legislação. Quando se exige um detalhamento do plano de trabalho nos termos acima descritos, do atingimento de metas, de etapas de execução etc., fica evidenciado o vínculo que se estabelece entre os partícipes no convênio, de um lado a execução do objeto e de outro o repasse de recursos.

Diante do apresentado, percebe-se que o convênio é um instrumento destinado à formalização da captação de recursos, financeiros, humanos e de bens, no qual a ausência de delimitação acerca dos temas que podem ser objeto da relação convenial tornam o instrumento apto a ser utilizado para a viabilização dos mais variados projetos, sendo possível incluir a regularização fundiária urbana de interesse social nesse rol.

\subsubsection{Sistema Nacional de Habitação de Interesse Social}

Criado pela Lei federal $\mathrm{n}^{0} 11.124 / 2005$, o Sistema Nacional de Habitação de Interesse Social (SNHIS) foi estruturado com o objetivo de viabilizar o acesso da população de menor renda à terra urbanizada e à habitação digna e sustentável, por meio da implementação de programas, abrangendo investimento e subsídio, de modo articulado, tanto entre os órgãos e instituições da esfera federal, como Ministério das Cidades e Caixa Econômica Federal, quanto entre os entes da federação.

No âmbito do SNHIS foi criado o Fundo Nacional de Habitação de Interesse Social (FNHIS) que apresenta como finalidade o financiamento de programas no âmbito do SNHIS e é o mecanismo pelo qual os recursos são centralizados e repassados para as demais esferas de governo ou para entidades privadas sem fins lucrativos ${ }^{240}$, respeitados os critérios previstos no art. $12, \S 6^{\circ}$ da Lei federal $n^{\circ} 11.124 / 2005 .^{241}$

\footnotetext{
239 Acerca do tema, conferir ARAÚJO, Edmir Neto de. Do negócio jurídico administrativo. São Paulo: Revista dos Tribunais, 1992, p. 146.

${ }^{240}$ A participação de entidades privadas sem fins lucrativos pode ser destacada no âmbito de da Produção Social da Moradia.

241 “Art. $12 \S 6^{\circ}$ Os recursos do FNHIS também poderão, na forma do regulamento, ser aplicados por meio de repasse a entidades privadas sem fins lucrativos, cujos objetivos estejam em consonância com os do Fundo, observados os seguintes parâmetros: I - a definição de valor-limite de aplicação por projeto e por entidade; II - o objeto social da entidade ser compatível com o projeto a ser implementado com os recursos repassados;
} 
Para receber recursos do FNHIS no âmbito do repasse interfederativo, o art. 12 da Lei federal $n^{\circ} 11.124 / 2005$ estabelece as seguintes obrigações aos Estados, Distrito Federal e Municípios: (i) constituição de fundo, com dotação orçamentária própria; (ii) constituição de conselho que contemple a participação de entidades públicas e privadas, bem como de segmentos da sociedade ligados ao setor de habitação, garantindo vagas aos representantes dos movimentos populares; (iii) apresentação de Plano Habitacional de Interesse Social; (iv) formalização do termo de adesão ao SNHIS; e (v) elaboração de relatórios de gestão.

Além de tais requisitos, referida Lei estabelece que o repasse efetivo de recursos fica condicionado ao oferecimento de contrapartidas do ente, seja por meio de recursos financeiros, de bens imóveis urbanos ou de serviços vinculados aos respectivos empreendimentos habitacionais realizados no âmbito dos programas do SNHIS, ${ }^{242}$ a serem formalizadas por meio de contrato de repasse firmado junto à Caixa Econômica Federal, agente operador do FNHIS. ${ }^{243}$

Assim, diferentemente de outros fundos especiais, como Fundo Nacional de Saúde (FNS) e os Fundos de Manutenção e Desenvolvimento da Educação Básica e de Valorização dos Profissionais da Educação (FUNDEB), que apresentam uma parcela de repasse automático de recursos, ${ }^{244}$ o FNHIS prevê tão somente o repasse condicionado à

III - o funcionamento regular da entidade por no mínimo 3 (três) anos; IV - a vedação de repasse a entidade que tenha como dirigentes membros dos Poderes Executivo, Legislativo, Judiciário, do Ministério Público e do Tribunal de Contas da União, bem como seus respectivos cônjuges, companheiros e parentes em linha reta, colateral ou por afinidade até o $2^{\circ}$ grau, ou servidor público vinculado ao Conselho Gestor do FNHIS ou ao Ministério das Cidades, bem como seus respectivos cônjuges, companheiros e parentes em linha reta, colateral ou por afinidade até o $2^{\circ}$ grau; $\mathrm{V}$ - o repasse de recursos do Fundo será precedido por chamada pública às entidades sem fins lucrativos, para seleção de projetos ou entidades que tornem mais eficaz o objeto da aplicação; VI - a utilização de normas contábeis aplicáveis para os registros a serem realizados na escrita contábil em relação aos recursos repassados pelo FNHIS; VII - a aquisição de produtos e a contratação de serviços com recursos da União transferidos a entidades deverão observar os princípios da impessoalidade, moralidade e economicidade, sendo necessária, no mínimo, a realização de cotação prévia de preços no mercado antes da celebração do contrato, para efeito do disposto no art. 116 da Lei $n^{\circ} 8.666$, de 21 de junho de 1993; VIII - o atendimento às demais normas aplicáveis às transferências de recursos pela União a entidades privadas." (Lei federal $\mathrm{n}^{\mathrm{0}} 11.124 / 2005$ )

${ }^{242}$ Art. $12, \S 2^{\circ}$ Lei federal $n^{\circ} 11.124 / 2005$.

${ }^{243}$ Art. 16 da Lei federal $\mathrm{n}^{\circ} 11.124 / 2005$ e art. $7^{\circ}$, inciso VII do Decreto $\mathrm{n}^{\mathrm{o}} 5.796 / 2006$.

${ }^{244}$ No caso do repasse no âmbito do SUS, a legislação estabelece que parcela dos recursos é repassada de forma regular e automática diretamente do Fundo Nacional de Saúde para os fundos dos Estados, Municípios e Distrito Federal, independentemente de convênio ou instrumento similar (art. $3^{\circ}$ da Lei $n^{\circ} 8142 / 1990$ ). Na área da educação, os recursos dos Fundos de Manutenção e Desenvolvimento da Educação Básica e de Valorização dos Profissionais da Educação (FUNDEB) também são repassados automaticamente para contas únicas e específicas dos Governos Estaduais, do Distrito Federal e dos Municípios, vinculadas ao respectivo Fundo (art. 17 da Lei no 11.494/2007). 
formalização do contrato de repasse ${ }^{245}$ que dependerá de aprovação da proposta de programa a ser desenvolvido com recursos do FNHIS, bem como da contrapartida oferecida.

$\mathrm{O}$ art. 11 da Lei federal $\mathrm{n}^{\circ} 11.124 / 2005$ estabelece previamente algumas das ações dentre as quais o Fundo já estaria autorizado a aplicar recursos ${ }^{246}$ e, portanto, receber propostas dos demais entes. Ainda assim, a elaboração das propostas deve seguir as diretrizes de programas já lançados na esfera federal, caracterizando-se como mera adesão ao programa formulado na esfera federal, restando pouca autonomia para sua formulação no âmbito dos Estados, Distrito Federal e Municípios. As propostas são encaminhadas no âmbito de um processo de seleção de propostas inaugurado na esfera federal, no qual há a definição dos objetivos do programa, das contrapartidas que serão aceitas e dos beneficiários que devem ser contemplados com a ação pública.

Um exemplo desse modelo de repasse é o Programa de Urbanização, Regularização e Integração de Assentamentos Precários, subsidiado com recursos do FNHIS. A finalidade do programa é a realização de:

"[...] intervenções necessárias à regularização fundiária, segurança,
salubridade e habitabilidade de população localizada em área inadequada
à moradia ou em situações de risco, visando a sua permanência ou
realocação, por intermédio da execução de ações integradas de habitação,
saneamento ambiental e inclusão social". ${ }^{247}$

Para apresentar propostas, o ente interessado, além de ter aderido ao SNHIS e preenchido todos os requisitos acima mencionados, deve oferecer contrapartidas de acordo com os percentuais mínimos e máximos definidos no processo de seleção de propostas, nos seguintes termos:

\footnotetext{
${ }^{245}$ Art. $1^{\circ}, \S 1^{\circ}$, inciso II: "contrato de repasse - instrumento administrativo por meio do qual a transferência dos recursos financeiros se processa por intermédio de instituição ou agente financeiro público federal, atuando como mandatário da União." (Decreto $\mathrm{n}^{\circ}$ 6.170/2007)

246 São elas: (i) aquisição, construção, conclusão, melhoria, reforma, locação social e arrendamento de unidades habitacionais em áreas urbanas e rurais; (ii) produção de lotes urbanizados para fins habitacionais; (iii) urbanização, produção de equipamentos comunitários, regularização fundiária e urbanística de áreas caracterizadas de interesse social; (iv) implantação de saneamento básico, infraestrutura e equipamentos urbanos, complementares aos programas habitacionais de interesse social; (v) aquisição de materiais para construção, ampliação e reforma de moradias; e (vi) recuperação ou produção de imóveis em áreas encortiçadas ou deterioradas, centrais ou periféricas, para fins habitacionais de interesse social.

247 Informações disponíveis no site do Ministério das Cidades: <http://www.cidades.gov.br/index.php/ programas-e-acoes/487-programa-urbanizacao-regularizacao-e-integracao-de-assentamentos-precarios $>$. Acesso em: 13 nov. 2012.
} 


\begin{tabular}{|c|c|l|}
\hline \multicolumn{2}{|c|}{$\begin{array}{c}\text { Limites (percentuais } \\
\text { do valor do } \\
\text { investimento) }\end{array}$} \\
\cline { 1 - 2 } Mínimo & Máximo & \\
\hline $2 \%$ & $4 \%$ & De até 50.000 (cinquenta mil) habitantes \\
\hline $4 \%$ & $8 \%$ & $\begin{array}{l}\text { Acima de } 50.000 \text { (cinquenta mil) habitantes localizados } \\
\text { em área prioritárias no âmbito do PNDR, SUDENE, } \\
\text { SUDAM e Região Centro-Oeste }\end{array}$ \\
\hline $8 \%$ & $40 \%$ & Demais \\
\hline
\end{tabular}

\begin{tabular}{|c|c|l|}
\hline \multicolumn{2}{|c|}{$\begin{array}{c}\text { Limites (percentuais } \\
\text { do valor do } \\
\text { investimento) }\end{array}$} & \multicolumn{2}{|c|}{ ESTADOS E DISTRITO FEDERAL } \\
\cline { 1 - 2 } Mínimo & Máximo & \\
\cline { 1 - 2 } $10 \%$ & $20 \%$ & $\begin{array}{l}\text { Localizados em área prioritárias no âmbito do PNDR, } \\
\text { SUDENE, SUDAM e Região Centro-Oeste }\end{array}$ \\
\cline { 1 - 2 } $20 \%$ & $40 \%$ & Demais \\
\hline
\end{tabular}

Além disso, os programas devem beneficiar área ocupada por no mínimo $60 \%$ (sessenta por cento) de famílias com renda de até $\mathrm{R} \$ 1.050,00$ (um mil e cinquenta reais); e, ainda, ser ocupada há mais de cinco anos ou estar localizada em situação que configure risco ou insalubridade. Por fim, há o estabelecimento de um rol de atividades que podem ser custeadas com os recursos repassados no âmbito do programa, tais como: (i) elaboração de projetos técnicos; (ii) aquisição do terreno e sua legalização; (iii) regularização jurídicofundiária do assentamento; (iv) edificação das unidades habitacionais; etc.

Ainda que haja previsão acerca do repasse de recursos no âmbito do SNHIS, previsto na Lei federal $\mathrm{n}^{0} 11.124 / 2005$, não há uma obrigatoriedade em realizá-lo, deixando na referida lei certa margem para a que o agente operador do FNHIS decida em concreto, diante das propostas e contrapartidas apresentadas.

O formato estruturado pela Lei federal $n^{0} 11.124 / 2005$ foi alargado em 2007, pela Lei federal $\mathrm{n}^{0} 11.578$, tendo em vista que as ações já executadas no âmbito do SNHIS incluídas nas ações do Programa de Aceleração do Crescimento (PAC), passaram a seguir outras regras. Ainda que haja certa semelhança, no lugar do contrato de repasse, o 
mecanismo passou a ser o repasse obrigatório, por meio de termo de compromisso contendo: (i) identificação do objeto a ser executado; (ii) metas a serem atingidas; (iii) etapas ou fases de execução; (iv) plano de aplicação dos recursos financeiros; (v) cronograma de desembolso; (vi) previsão de início e fim da execução do objeto, bem como da conclusão das etapas ou fases programadas; e (vii) comprovação de que os recursos próprios para complementar a execução do objeto, salvo se o custo total do empreendimento recair sobre a entidade ou órgão descentralizador, quando a ação compreender obra ou serviço de engenharia.

Desse modo, o FNHIS passou a firmar, além dos contratos de repasse, que apresentam a voluntariedade como característica central, os termos de compromisso no âmbito do PAC, cujo repasse é obrigatório, ou seja, havendo cumprimento dos requisitos exigidos pela Lei federal $\mathrm{n}^{\circ} 11.578 / 2007$, não há margem de decisão acerca da formalização ou não do repasse.

Essa pode ser uma das razões pela qual se observa, a partir do relatório de auditoria produzido pela Controladoria Geral da União em 2010, a baixa execução orçamentária da transferências correspondentes às ações "não PAC". Comparadas ainda a outros programas de financiamento federal, como o Programa Minha Casa Minha Vida, a discrepância fica ainda mais evidente. Enquanto as transferências no âmbito do FNHIS chegam a 37,15\%, no máximo, as despesas no âmbito do Programa Minha Casa Minha Vida apresentam uma ampla superação da meta orçamentária prevista, chegando a 3000\% (três mil por cento) superiores aos valores inicialmente previstos.

A partir do exposto, é possível observar que o FNHIS apresenta-se como alternativa para que Estados, Distrito Federal e Municípios ou, ainda, entidades privadas sem fins lucrativos, recebem recursos a título de repasse para implementação de programas de regularização fundiária urbana de interesse social. Entretanto, o recebimento de recursos no âmbito do FNHIS para a realização de projetos de regularização fundiária urbana de interesse social apresenta entraves decorrentes: (i) da ausência de repasse automático que envolva diretamente programas de regularização fundiária de interesse social; (ii) da impossibilidade dos Estados, Distrito Federal e Municípios formularem os programas de modo diverso do estabelecido na esfera federal; (iii) da priorização de outros programas de governo na esfera federal. 


\subsubsection{Consórcio público}

Previsto no art. 241 da Constituição Federal, cuja redação foi dada pela Emenda Constitucional $n^{0}$ 19/1998, o consórcio público é instrumento capaz de viabilizar a gestão associada de serviços públicos, bem como a transferência total ou parcial de encargos, serviços, pessoal e bens essenciais à continuidade dos serviços transferidos, entre a União, os Estados o Distrito Federal e os Municípios. Trata-se de mecanismo por meio do qual dois ou mais entes da Federação unem esforços para a realização de um objetivo comum, ${ }^{248}$ de modo a possibilitar um rearranjo no âmbito do exercício das competências constitucionais.

A despeito da semelhança com o convênio, o marco legal dos consórcios públicos cuidou de estabelecer uma série de peculiaridades que os tornam uma alternativa diferenciada para a promoção de políticas públicas. ${ }^{249}$

Um primeiro aspecto que desponta se refere à forma de sua constituição, à medida que o art. $3^{\circ}$, caput, da Lei federal $n^{\circ} 11.107 / 2005$, que regulamenta o instituto, cuidou de estabelecer a constituição do consórcio público por meio de contrato. Essa iniciativa do constituinte e do legislador foi de encontro ao entendimento de parcela da doutrina administrativista que afastava o consórcio da figura do contrato, tendo em vista a relação colaborativa inerente aos consórcios e a ausência de antagonismo de interesses. ${ }^{250}$

Salienta-se, entretanto, que o elemento da cooperação não é atributo inexistente nos contratos administrativos. Muito pelo contrário. A evolução dos arranjos aos quais a administração pública pode fazer uso tem cada vez mais adotado a colaboração como aspecto presente de maneira mais ou menos explícita a depender da modalidade contratual

\footnotetext{
${ }^{248}$ A própria expressão "consórcio público" remete "à ideia de conjugação, ao somatório de esforços e ao concurso de meios e capacidades para que dois ou mais entes atinjam objetivos no todo ou em parte comuns, convergindo e concertando seus esforços." (MARQUES NETO, op. cit., 2005, p.8.)

249 Acerca da diferença entre consórcio e convênio, Marques Neto afirma: "Tenho para comigo que a distinção que se pode extrair do artigo 241 diz respeito ao tipo de cooperação concertada entre os entes. Enquanto no convênio se estabelece uma relação de cooperação em que um ente fornece meios para que o outro exerça suas competências, provendo-o do quanto necessário e transferindo-lhe eventualmente obrigações, no consórcio há uma soma de esforços por meio da qual os entes consorciados, de forma perene, passam a exercer cada qual suas competências através do ente consorcial. Naquele (convênio) delega-se o exercício de uma atividade pública de um ente para outro. Neste (consórcio) exerce-se conjuntamente as competências de cada ente por um ente por eles integrado.” (MARQUES NETO, op. cit., 2005, p.14)

${ }^{250}$ Nesse sentido, Di Pietro ressalta: "Existem pontos comuns entre o consórcio e o convênio, porque o objetivo é o de reunir esforços para a consecução de fins comuns às entidades consorciadas ou conveniadas. Em ambos, existe um acordo de vontades que não chega a ser um contrato, precisamente pelo fato de os interesses serem comuns, ao passo que, no contrato, os interesses são contrapostos." (DI PIETRO, op. cit., 2005, p. 300-301).
} 
utilizada. Essa, inclusive, é a razão pela qual o vocábulo "parceria" tem sido adotado para qualificar parcela dos contratos administrativos, conforme ensina Di Pietro:

[...] o vocábulo parceria é utilizado para designar todas as formas de sociedade que, sem formar uma nova pessoa jurídica, são organizadas entre os setores público e privado, para a consecução de fins de interesse público. Nela existe a colaboração entre o poder público e a iniciativa privada nos âmbitos social e econômico, para a satisfação de interesses públicos, ainda que, do lado do particular, se objetive o lucro. Todavia, a natureza econômica da atividade não é essencial para caracterizar a parceria, como também não é a ideia do lucro, já que a parceria pode darse com as entidades privadas sem fins lucrativos que atuam essencialmente na área social e não econômica. ${ }^{251}$

No mesmo sentido, Odete Medauar destaca que, em verdade, o reconhecimento de que há um módulo contratual da administração pública decorrente do consenso, acordo, cooperação e parceria entre administração e particulares já podia ser depreendido mesmo nos contratos administrativos clássicos, se fosse abandonada a concepção restrita de contrato, vigente no século XIX:

Tal afirmação pode ser feita se for deixado de lado a concepção restrita de contrato, vigente no século XIX, centrada na autonomia da vontade, na igualdade absoluta entre as partes e na imutabilidade da vontade inicial das mesmas. Se for retomada a ideia básica de contrato, predominante na Grécia clássica e no Direito Romano mais antigo, centrada no intercâmbio de bens e prestações, regido pelo direito, pode-se cogitar de um módulo contratual formado por vários tipos de contratos, com regimes jurídicos diversos. ${ }^{252}$

Apenas para exemplificar, já que transborda ao escopo do presente tópico esmiuçar o tema, destacam-se algumas modalidades de contratos administrativos em que fica evidente o caráter da colaboração: (i) as concessões de serviços públicos, regidas pela Lei federal $n^{0} 8.987 / 1995$, na qual é delegada ao particular a prestação de um serviço público, sob regulação estatal; (ii) os contratos de gestão com Organizações Sociais, criados pela Lei federal $\mathrm{n}^{\text {o }}$ 9.637/1998, objeto deste estudo; (iii) os Termos de Parceria com Organizações da Sociedade Civil de Interesse Público (OSCIP) da Lei federal 9.790/1999;

251 DI PIETRO, Maria Sylvia Zanella. Parcerias na Administração Pública. Concessão, Permissão, Franquia, Terceirização, Parceria Público-Privada e outras Formas. 6. ed. São Paulo: Atlas, 2008, p. 22. Marques Neto acrescenta: "No direito administrativo, doutro bordo, este afastamento do caráter contratual para os ajustes de vontade em que não estejam presentes a bilateralidade e o antagonismo de vontades tampouco se sustenta nos dias de hoje sobretudo quando se multiplicam ajustes que, sem estas duas especificidades, são tratados como contratos. [...] Bem se vê, portanto, que existem contratos submetidos ao direito público e que, inobstante, não são especificamente bilaterais e nem envolvem sinalagma, antagonismo de vontades." (MARQUES NETO, op. cit., 2005, p. 22).

${ }^{252}$ MEDAUAR, Odete. O Direito Administrativo Moderno. 7. ed. São Paulo: RT, 2003, pp. 228 e 229. 
e, mais recentemente, (iv) parcerias público-privadas, regidas pela Lei federal $\mathrm{n}^{\circ}$ $11.079 / 2005$.

Fixada, portanto, a natureza contratual do consórcio, a Lei estabelece a necessidade de prévia subscrição de protocolo de intenções para celebração do contrato de consórcio público. Para tanto, além da ratificação do protocolo de intenções em cada uma das casas legislativas dos entes da Federação envolvidos no consórcio, ${ }^{253}$ são cláusulas obrigatórias do protocolo aquelas previstas no art. $4^{\circ}$ da Lei federal $n^{\circ} 11.107 / 2005,{ }^{254}$ dentre as quais se destacam: (i) a previsão de que o consórcio público é associação pública ou pessoa jurídica de direito privado ${ }^{255}$ sem fins econômicos, ou seja, que constitui personalidade jurídica própria, passando a compor a administração indireta dos entes envolvidos no contrato de consórcio; ${ }^{256}$ (ii) a possibilidade de celebração de contratos, dentre os quais se destaca o contrato de programa, no caso de a gestão associada envolver também a prestação de serviços por órgão ou entidade de um dos entes da Federação consorciados.

A criação de entidade com personalidade jurídica própria garante maior autonomia, econômico-financeira e administrativa, para que o próprio ente consorcial efetive o objetivo da cooperação, assumindo obrigações de maneira mais independente.

\footnotetext{
${ }^{253}$ Buscando garantir o pacto federativo, a União pode se consorciar com os Estados, os Estados podem se consorciar com outros Estados ou Municípios dentro de seu território e os Municípios podem formalizar consórcio com o Estado em que se localiza e demais Municípios.

254 “Art. $4^{\circ}$ São cláusulas necessárias do protocolo de intenções as que estabeleçam: I - a denominação, a finalidade, o prazo de duração e a sede do consórcio; II - a identificação dos entes da Federação consorciados; III - a indicação da área de atuação do consórcio; IV - a previsão de que o consórcio público é associação pública ou pessoa jurídica de direito privado sem fins econômicos; V - os critérios para, em assuntos de interesse comum, autorizar o consórcio público a representar os entes da Federação consorciados perante outras esferas de governo; VI - as normas de convocação e funcionamento da assembléia geral, inclusive para a elaboração, aprovação e modificação dos estatutos do consórcio público; VII - a previsão de que a assembléia geral é a instância máxima do consórcio público e o número de votos para as suas deliberações; VIII - a forma de eleição e a duração do mandato do representante legal do consórcio público que, obrigatoriamente, deverá ser Chefe do Poder Executivo de ente da Federação consorciado; IX - o número, as formas de provimento e a remuneração dos empregados públicos, bem como os casos de contratação por tempo determinado para atender a necessidade temporária de excepcional interesse público; $\mathrm{X}$ - as condições para que o consórcio público celebre contrato de gestão ou termo de parceria; XI - a autorização para a gestão associada de serviços públicos, explicitando: a) as competências cujo exercício se transferiu ao consórcio público; b) os serviços públicos objeto da gestão associada e a área em que serão prestados; c) a autorização para licitar ou outorgar concessão, permissão ou autorização da prestação dos serviços; d) as condições a que deve obedecer o contrato de programa, no caso de a gestão associada envolver também a prestação de serviços por órgão ou entidade de um dos entes da Federação consorciados; e) os critérios técnicos para cálculo do valor das tarifas e de outros preços públicos, bem como para seu reajuste ou revisão; e XII - o direito de qualquer dos contratantes, quando adimplente com suas obrigações, de exigir o pleno cumprimento das cláusulas do contrato de consórcio público." (Lei federal no 11.107/2005).

${ }^{255}$ Apesar da possibilidade do consórcio assumir natureza jurídica de direito privado, a legislação estabelece a observância das normas de direito público no que concerne à realização de licitação, celebração de contratos, prestação de contas e admissão de pessoal, que será regido pela Consolidação das Leis do Trabalho - CLT. (Art. $6^{\circ}$, § $2^{\circ}$ da Lei federal no $11.107 / 2005$ ).

${ }^{256}$ Art. $6^{\circ}$ da Lei federal $n^{\circ} 11.107 / 2005$.
} 
No âmbito econômico-financeiro, a autonomia pode ser observada quando a lei prevê a necessidade de realização de contrato de rateio, firmado entre o ente da Federação e o consórcio público, regulado pelo art. $8^{\circ}$ da Lei federal $n^{0} 11.107 / 2005 .{ }^{257}$ Com isso, garante-se maior previsibilidade acerca do montante de recursos repassados, bem como o compromisso assumido entre os entes em relação a tais recursos. ${ }^{258}$

No campo da autonomia administrativa, o contrato de programa é o veículo pelo qual o consórcio formaliza com órgão da administração direta ou entidade da administração indireta a prestação de serviços, a transferência de encargos, serviços, pessoal ou bens, no âmbito da gestão associada. Os detalhamentos do contrato de programa encontram-se previstos no art. 13 da Lei federal $n^{\circ} 11.107 / 2005$, que estabelece a aplicabilidade da legislação referente às concessões e permissões de serviços públicos.

Apesar da regulação do contrato de programa aproximá-lo do regime das concessões e permissões que regulam a delegação de serviços públicos em estrito senso, ${ }^{259}$ entendido como aqueles prestados com exclusividade pelo estado no âmbito do exercício

257 “Art. $8^{\circ}$ Os entes consorciados somente entregarão recursos ao consórcio público mediante contrato de rateio. $\S 1^{\circ} \mathrm{O}$ contrato de rateio será formalizado em cada exercício financeiro e seu prazo de vigência não será superior ao das dotações que o suportam, com exceção dos contratos que tenham por objeto exclusivamente projetos consistentes em programas e ações contemplados em plano plurianual ou a gestão associada de serviços públicos custeados por tarifas ou outros preços públicos. $\S 2^{\circ}$ É vedada a aplicação dos recursos entregues por meio de contrato de rateio para o atendimento de despesas genéricas, inclusive transferências ou operações de crédito. $\S 3^{\circ}$ Os entes consorciados, isolados ou em conjunto, bem como o consórcio público, são partes legítimas para exigir o cumprimento das obrigações previstas no contrato de rateio. $\$ 4^{\circ}$ Com o objetivo de permitir o atendimento dos dispositivos da Lei Complementar $n^{\circ} 101$, de 4 de maio de 2000, o consórcio público deve fornecer as informações necessárias para que sejam consolidadas, nas contas dos entes consorciados, todas as despesas realizadas com os recursos entregues em virtude de contrato de rateio, de forma que possam ser contabilizadas nas contas de cada ente da Federação na conformidade dos elementos econômicos e das atividades ou projetos atendidos. $\S 5^{\circ}$ Poderá ser excluído do consórcio público, após prévia suspensão, o ente consorciado que não consignar, em sua lei orçamentária ou em créditos adicionais, as dotações suficientes para suportar as despesas assumidas por meio de contrato de rateio." (Lei federal $n^{\circ} 11.107 / 2005$ ).

258 "Com isso, observadas as normas de direito financeiro, especialmente as de responsabilidade fiscal, o consórcio adquire a segurança de haver como contratados os recursos que lhe serão entregues, fazendo-os exigíveis, fornecendo segurança para a sua gestão administrativo-financeira." (RIBEIRO, Wladimir António. Nota Técnica sobre a Legalidade e Constitucionalidade do Anteprojeto de Lei criado pela Portaria 1.391/Ccivil/2003. In: Revista Eletrônica de Direito do Estado, Salvador, Instituto de Direito Público da Bahia, no. 3, julho/agosto/setembro, 2005. Disponível em: $<$ http://www.direitodoestado.com.br $>$. Acesso em: 22 nov.2012).

${ }^{259}$ A classificação dos serviços públicos entendidos em sentido estrito foi instituída doutrinariamente com a finalidade identificar os serviços públicos exclusivamente prestados pelo Estado, sendo passíveis de delegação à iniciativa privada no âmbito do art. 175 da Constituição Federal. Entretanto, com a aprovação da Lei das Parcerias Público-Privadas, é possível afirmar que os serviços públicos passíveis de delegação, com fundamento no art. 175 da Constituição Federal, foram ampliados, tendo em vista que as modalidades de delegação previstas na referida lei abrangem também aqueles serviços públicos não exclusivos, como saúde e educação. Acerca do tema, conferir: SCHIRATO, Vitor Rhein. A noção de serviço público nas parcerias público-privadas. In: Revista de Direito Público da Economia RDPE, Belo Horizonte, ano 5, n. 20, pp. $219-$ 235, out./dez. 2007. Disponível em: <http://www.bidforum.com.br/bid/PDI0006.aspx?pdiCntd=49825>. Acesso em: 02 jul. 2012. 
de atividade econômica, delegados de acordo com a Lei federal $n^{0} 8.987 / 1995$, não é possível extrair da regulação dos consórcios públicos ou dos contratos de programa que apenas esses serviços sejam passíveis de contratação. Isso porque, além da expressão "serviços públicos" na Constituição Federal ser utilizada no sentido de englobar nesse conceito serviços que não tenham necessariamente referido conteúdo, como os serviços de saúde e educação, o art. 241 cuidou de mencionar o termo "gestão" e não somente a execução ou prestação de tais serviços públicos. ${ }^{260}$

Por fim, cumpre destacar que a retirada de ente da Federação do consórcio público dependerá tão somente de ato formal de seu representante na assembleia geral do consórcio, na forma previamente disciplinada no protocolo de intenções. Embora o procedimento seja simples, a saída de um dos entes ou, ainda, a extinção do consórcio público não prejudicará as obrigações já constituídas, inclusive os contratos de programa, cuja extinção dependerá do prévio pagamento das indenizações eventualmente devidas.

Traçadas as diretrizes gerais do instrumento, sua aplicabilidade no âmbito de projetos de regularização fundiária urbana de interesse social pode ocorrer em decorrência das mais variadas situações que, de alguma maneira, justificam a atuação conjunta de mais de um ente na busca por uma solução, principalmente diante da constatação de que muitos assentamentos irregulares estão inseridos em localidades que ultrapassam a circunscrição de um determinado Município.

A urbanização da Favela Naval, localizada em uma região que compreendia o município de Diadema e o Município de São Bernardo do Campo, pode ilustrar a questão. O tratamento da problemática foi iniciado em 2005, por meio do consorciamento dos Municípios estimulados pela Câmara Regional do Grande ABC, e, apesar dos Municípios diretamente envolvidos na questão terem objetivos diferentes, já que Diadema pretendia realizar a urbanização da favela, com recursos federais provenientes do Habitar Brasil, e São Bernardo do Campo tinha como objetivo central a implementação de um anel viário na região, com recursos federais do Programa de Transporte Urbano juntamente com o BID, a parceria foi formalizada diante do reconhecimento da interdependência de ambos os

\footnotetext{
${ }^{260}$ MARQUES NETO esclarece: "No artigo 241, o texto alude apenas à gestão de serviços públicos genericamente considerados. E cuida-se não de exploração ou prestação (o que permitiria pensar naqueles serviços públicos espécie de atividade econômica) e, sim, de gestão (algo muito mais amplo, inerente à titularidade do serviço).” (MARQUES NETO, op. cit., 2005, p. 15).
} 
projetos. $^{261}$

Situação frequentemente encontrada em regiões metropolitanas, que apresentam uma concentração de favelas e loteamentos irregulares decorrentes de uma problemática conjunta e interligada, ${ }^{262}$ o consórcio público pode ser capaz de formalizar o acordo entre os entes e a flexibilização das competências, já que apenas a criação de regiões metropolitanas pelos Estados não tem se demonstrado suficiente para a união de esforços necessária para o tratamento conjunto da complexidade dos problemas metropolitanos, por razões históricas ${ }^{263}$ e como decorrência da necessidade de flexibilização da competência Municipal, que dificilmente ocorre de modo compulsório. ${ }^{264}$

Os consórcios públicos, portanto, são mecanismos úteis para: (i) possibilitar uma repartição de encargos e custos entre mais de um ente da federação para a realização de

\footnotetext{
${ }^{261}$ Segundo aponta o estudo coordenado por Hugh KELLAS: "Os projetos rodoviários e de assentamento mobilizaram recursos da ordem de 113 milhões de reais: 26 milhões de reais investidos em Diadema por meio do PAC e cerca de 87 milhões de reais investidos em São Bernardo, dos quais 32 milhões de reais são do PAC e 55 milhões de reais são provenientes do Programa de Transportes Urbanos, financiados pelo Banco Mundial. [...] A principal dificuldade do momento é coordenar o ritmo e os prazos das intervenções." (KELLAS, Hugh. Região do Grande ABC. Diadema e São Bernardo do Campo - O Projeto da Favela Naval. In: Inclusão, colaboração e governança urbana. Experiências brasileiras e canadenses. Coleção Limites da Cidade. Canadá: The University of British Columbia; Observatório das Metrópoles; Belo Horizonte: Editora PUC Minas, 2010, p. 37-38 e 41).

${ }^{262}$ Reforçando a problemática no âmbito metropolitano, Suzana Pasternak vai além e afirma: “[...] o fenômeno da favelização é nitidamente metropolitano: em 1980, 79,16\% dos favelados estavam nas 9 (nove) regiões metropolitanas" (PASTERNAK, Suzana. Favelas e cortiços: vinte anos de pesquisa urbana no Brasil, Cadernos IPPUR, Rio de Janeiro, Ano X, nº 2, 1996, p. 92).

${ }^{263}$ Azevedo e Guia identificam três fases históricas que acabam por justificar a dificuldade prática da problemática metropolitana ser tratada no âmbito apenas da criação de regiões metropolitanas. Na primeira fase, compreendida entre os anos de 1973 e 1988, como decorrência do próprio regime militar, o instituto ficou marcado pela centralização e pelo autoritarismo, já que eram instituídas pela União e ficavam a cargo dos Estados, sem qualquer envolvimento do Município. A segunda, marcada pelo movimento municipalista e pelo neolocalismo pós-Constituição de 1988 , identificava no art. $25, \S 3^{\circ}$, da Constituição Federal, foi mero resquício do regime militar. Ainda que a lógica fosse um pouco diferente, na medida em que a atual Constituição, além de prever que a instituição das regiões metropolitanas, aglomerações e microrregiões se dá pelo Estado, há um expresso reconhecimento da autonomia político, administrativa e financeira do Município que antes não havia. A terceira, tendo como marco inicial meados da década de 1990 e até hoje em desenvolvimento, caracteriza-se pela celebração de diversas parcerias metropolitanas e pelo processo de formação de redes nacionais, abrangendo associações voluntárias no âmbito metropolitano e compulsórias na esfera supranacional - exemplificada pela gestão das bacias hidrográficas. (AZEVEDO, Sérgio de; GUIA, Virgínia Rennó dos Mares. Os Dilemas da Gestão Metropolitana no Brasil. In: Metrópoles: entre a coesão e a fragmentação, a cooperação e o conflito. Fundação Perseu Abramo/FASE/Observatório das Metrópolis, 2004, p.106).

${ }^{264}$ Atualmente, ainda que haja um contexto político-institucional que equilibra as três esferas de governo, a dificuldade de planejamento e execução de políticas no âmbito metropolitano não decorre mais da ausência de um reconhecimento de interesses ou problemas comuns e interligados, e sim da relativização da autonomia Municipal, não apenas em face do Estado, mas também em relação aos demais Municípios, aliada à histórica desigualdade inter e intra-regional que gera desequilíbrios, ainda mais quando congregados nas regiões metropolitanas, aglomerações e microrregiões. (SOUZA, Celina. Regiões Metropolitanas. In: Metrópoles: entre a coesão e a fragmentação, a cooperação $e$ o conflito. Fundação Perseu Abramo/FASE/Observatório das Metrópoles, 2004, p. 92).
} 
projetos de regularização fundiária urbana de interesse social; e (ii) contribuir para a solução conjunta em regiões metropolitanas, onde há concentração de irregularidades passíveis de serem inseridas no objeto da regularização fundiária urbana de interesse social.

\subsubsection{Parceria público-privada}

Antes de iniciar a abordagem do tema, importa salientar que no presente tópico o termo Parceria Público-Privada (PPP) será utilizado de modo restritíssimo ${ }^{265}$ para designar tão somente as modalidades contratuais previstas na Lei federal $n^{\circ} 11.079 / 2005$ - Lei das PPPs: concessão patrocinada e concessão administrativa. Nesse sentido, a apresentação das alternativas contratuais terá como foco, além da análise acerca da aplicabilidade a projetos de regularização fundiária urbana de interesse social, as características peculiares dessa forma de ajuste que possibilitam a viabilização de investimento no setor.

A Lei das PPPs, por meio das concessões patrocinada e administrativa, cuidou de alargar o conteúdo de serviços passíveis de delegação pelo Poder Público à iniciativa privada, tendo em vista que antes de 2005 a regulação do art. $175^{266}$ da Constituição Federal decorria apenas da Lei federal $n^{\circ} 8.987 / 1995$, que deixa pouca margem para a delegação de serviços públicos que não sejam exclusivamente explorados pelo Poder Público. ${ }^{267}$

\footnotetext{
${ }^{265}$ Diz-se em sentido restritíssimo, tendo em vista a classificação adotada por Marques Neto. Considerando a variedade de significados que o termo "parceria público-privada" por assumir, o autor divide a abrangência do termo em três grupos. Além do sentido restritíssimo, já mencionado, o termo pode ser utilizado: (i) de maneira ampla para designar qualquer tipo de parceria que o poder público estabelece com a iniciativa privada para o desenvolvimento de atividades de interesse coletivo, abrangendo, desde os mecanismos de fomento até atividades contratuais, incluindo a criação de sociedades de economia mista; (ii) de modo restrito para identificar as contratações realizadas pelo Poder Público com a finalidade de satisfazer necessidades coletivas, como a formalização de contrato de gestão, termos de parceria, concessões e permissões, e as parcerias público-privadas regidas pela Lei federal $\mathrm{n}^{\circ} 11.079 / 2005$. (Fundamentos e conceituação das PPP. In MARQUES NETO, Floriano de Azevedo; SCHIRATO, Vitor Rhein (coord.). Estudo Sobre a Lei das Parcerias Público-Privadas., Belo Horizonte: Editora Fórum, 2011, p. 21-22).

266 “Art. 175. Incumbe ao Poder Público, na forma da lei, diretamente ou sob regime de concessão ou permissão, sempre através de licitação, a prestação de serviços públicos. Parágrafo único. A lei disporá sobre: I - o regime das empresas concessionárias e permissionárias de serviços públicos, o caráter especial de seu contrato e de sua prorrogação, bem como as condições de caducidade, fiscalização e rescisão da concessão ou permissão; II - os direitos dos usuários; III - política tarifária; IV - a obrigação de manter serviço adequado." (CF, grifo nosso)

${ }^{267}$ Ainda que se reconheça a possibilidade da concessão de obra pública ser também regulada pela mencionada norma, não cabe ao presente estudo abordar o tema com profundidade.
} 
De modo sintético, a interpretação dominante até a aprovação da Lei das PPPs adotava como premissa que, estando o art. 175 da Constituição Federal inserido no Título VII referente à ordem econômica e financeira, apenas os serviços públicos passíveis de exploração econômica exclusiva pelo Poder Público estariam compreendidos no conceito de "serviço público" previsto pelo caput do dispositivo constitucional, ou seja, serviços públicos comerciais e industriais do Estado ${ }^{268}$ previstos na Constituição Federal, como os serviços postal, de telecomunicações, de energia elétrica e de transporte.

O fato do inciso III, Parágrafo único do art. 175 da Constituição Federal, mencionar a "política tarifária", além de reforçar a lógica de que o conceito compreendia apenas os serviços passíveis de exploração econômica exclusiva pelo Poder Público (passíveis de cobrança de tarifa), importava na necessidade do serviço ser também divisível, como decorrência do próprio conceito de tarifa.

Sem embargo de parecer coerente, a interpretação narrada parte de algumas premissas que não podem ser extraídas dos dispositivos constitucionais e correspondem à tentativa de buscar respaldo constitucional a um entendimento cristalizado entre alguns doutrinadores, no sentido de que "só há concessão de serviço público quando o Estado considera o serviço em causa como próprio e como privativo do Poder Público „269, sendo “indispensável - sem o quê não se caracterizaria como concessão de serviço público - que o concessionário se remunere pela 'exploração' do próprio serviço concedido ,270.

Não parece possível, no entanto, definir o conteúdo de "serviço público" passível de delegação como aquele de exploração exclusiva pelo Poder Público e divisível, apenas pelo fato do termo ter sido mencionado em dispositivo inserido no título destinado à Ordem Econômica. Em primeiro lugar, porque não há essa delimitação no dispositivo constitucional. Em segundo, tendo em vista que não são apenas os serviços públicos de exploração exclusiva do Poder Público que apresentam um conteúdo econômico passível de exploração. ${ }^{271}$ É, inclusive, o conteúdo econômico de alguns serviços não exclusivos

\footnotetext{
${ }^{268}$ DI PIETRO, op. cit.,2005, p. 105.

${ }^{269}$ MELlo, Celso Antônio Bandeira de. Curso de Direito Administrativo. 20. ed. São Paulo: Malheiros, 2005 , p. 673.

${ }^{270}$ MELLO, op. cit., p. 665.

${ }^{271}$ Seriam, portanto, delegáveis, os serviços públicos compreendidos no conceito de atividade econômica em sentido amplo, segundo classificação de Eros Grau (A ordem econômica na Constituição de 1988. 13. ed. São Paulo: Malheiros, 2008, p.135), permanecendo excluídos da possibilidade de delegação aquelas atividades que envolvem de alguma maneira o manejo do poder estatal, como as funções de regulação, planejamento, atividade jurisdicional, exercício do poder de polícia etc., conforme a própria Lei das PPPs excepciona no art. $4^{\circ}$, inciso III.
} 
que permite a convivência de serviços públicos e privados em um mesmo setor, como ocorre com a saúde, a educação e a habitação, por exemplo. ${ }^{272}$

A exploração econômica dos serviços públicos exclusivos e os não exclusivos dá-se de modo diverso, já que não há cobrança de tarifa nesse último caso, tendo em vista serem, em regra, gratuitos ou indivisíveis. Daí decorre o segundo equívoco, no nosso entender. Não é possível depreender do dispositivo constitucional que apenas os serviços passíveis de cobrança de tarifa ${ }^{273}$ sejam delegáveis por meio de concessão. $\mathrm{O}$ fato de a constituição mencionar a política tarifária, não importa na necessária vinculação entre o serviço público e a cobrança de tarifa, já que a política tarifária pode indicar, justamente, a inexistência de tarifa. Essa é a função do dispositivo, indicar a necessidade de haver uma avaliação acerca da necessidade e viabilidade da cobrança de tarifa. ${ }^{274}$

Considerando, portanto, inadequada a conceituação restritiva de "serviço público" previsto no art. 175 da Constituição Federal e, consequentemente, da abrangência da concessão ali disciplinada, a Lei das PPPs surge não apenas inaugurando outras possíveis formas de concessão de serviços públicos, ampliando o conceito anteriormente disseminado e positivado pela Lei federal $n^{\circ} 8.987 / 1995$, como também criando novos mecanismos para garantir a atratividade de projetos de PPP e a repartição mais agressiva de riscos com a iniciativa privada.

Iniciando o exame da Lei das PPPs, cumpre de partida expor o conceito de cada uma das alternativas de contratuais criadas para delegação de serviços pelo Poder Público $^{275}$ ao concessionário. ${ }^{276}$

\footnotetext{
${ }^{272}$ Marques Neto ressalta sobre o tema: "Ou seja, os serviços públicos que podem ser objeto de delegação nos termos do art. 175 ( e na forma que a lei vier a predicar conforme o $\$ 1^{\circ}$ deste art. 175) hão de ser, por sua natureza delegáveis (sem que isso pressuponha renúncia de competência ou trespasse de poder extroverso), terão natureza econômica (poderão ser objeto de exploração econômica, é dizer, explorados com vista a obtenção de lucro), mas não estão reduzidos àqueles serviços públicos em sentido restritíssimo de que nos fala Alexandre Santos Aragão (os serviços públicos industriais clássicos, remunerados por tarifa, que sejam dividíveis e sejam fruíveis diretamente pelo administrado-usuário-consumidor)" (MARQUES NETO, op. cit., 2011, p. 25).

${ }^{273} \mathrm{Ou}$ outra forma de exploração do bem ou do serviço que venha a gerar receitas alternativa, acessória ou complementares, conforme o disposto no art. 11 da Lei federal $\mathrm{n}^{\circ}$ 8.987/1995.

${ }^{274}$ Conferir Marques Neto em Concessão de Serviço Público sem ônus para o Usuário. In: WAGNER JUNIOR, Luiz Guilherme Costa (coord.). Direito Público. Estudos em Homenagem ao Professor Adilson Abreu Dallari. Belo horizonte: Del Rey, 2004, pp. 331-351.

${ }^{275}$ A Lei das PPPs estabelece como "Poder Público", o previsto no art. $1^{\circ}$ da "Art. $1^{\circ}$ Esta Lei institui normas gerais para licitação e contratação de parceria público-privada no âmbito dos Poderes da União, dos Estados, do Distrito Federal e dos Municípios. Parágrafo único. Esta Lei se aplica aos órgãos da Administração Pública direta, aos fundos especiais, às autarquias, às fundações públicas, às empresas públicas, às sociedades de economia mista e às demais entidades controladas direta ou indiretamente pela União, Estados, Distrito Federal e Municípios."
} 
Segundo o disposto no art. $2^{\circ}, \S 1^{\circ}$, a concessão patrocinada nada mais é do que uma concessão comum regulada pela Lei federal $n^{\circ}$ 8.987/1995, seja de serviço ou de obra pública, que, em decorrência do objeto, não tem viabilidade econômico-financeira apenas com o recolhimento das tarifas, sendo imprescindível o pagamento adicional de contraprestação pública pecuniária pelo Poder Público para que o objeto seja realizado.

A concessão administrativa prevista no art. $2^{\circ}, \S 2^{\circ}$, por sua vez, é o contrato de prestação de serviços, que pode compreender obras e fornecimento de bens, de que a Administração Pública seja a usuária direta ou indireta. A partir desse conceito, a concessão administrativa por abranger: (i) a delegação de serviços que não sejam necessariamente "serviços públicos", mas que tenham a Administração como usuária direta, como a construção e operação de estádios ou de centros administrativos; e (ii) a delegação de serviços públicos em que a Administração seja identificada como usuária indireta, como os serviços de saúde, educação e habitação de interesse social, por exemplo. Como em ambos os casos a Lei das PPPs identifica a Administração Pública como usuária do serviço, é ela que remunera o concessionário por meio de contraprestação pública. ${ }^{277}$

É evidente que o fato da Administração Pública remunerar o concessionário por meio da contraprestação pública não importa em afirmar que a remuneração está restrita ao pagamento da contraprestação pública pela Administração, no caso da concessão administrativa, ou que somente pode ser completada com a cobrança de tarifa, no caso da concessão patrocinada. A Lei das PPPs, seguindo orientação da Lei federal n 8.987/1995, prevê a possibilidade de serem inseridas como parte da remuneração, as receitas alternativas, complementares, acessórias ou de projetos associados, nesse caso, para garantir a redução da contraprestação pública ou a modicidade tarifária.

Além de tais características, há algumas vedações para a contratação por meio de PPP, não sendo permitida nos seguintes casos: (i) valor do contrato inferior a $\mathrm{R} \$$ 20.000.000,00 (vinte milhões de reais); (ii) período de prestação do serviço inferior a 5 (cinco) anos e superior a 35 (trinta e cinco) anos, capaz de garantir a amortização dos investimentos; ou (iii) contrato que tenha como objeto único o fornecimento de mão-de-

\footnotetext{
${ }^{276}$ Apenas para registro, já que foge ao escopo do trabalho uma abordagem mais profunda do tema, a Lei das PPPs exige, para a assinatura do contrato de concessão, a criação de uma Sociedade de Propósito Específico $\left(\operatorname{art.} 9^{\circ}\right.$ ). Segrega, assim, os recursos envolvidos na concessão, do patrimônio das empresas que compõem a SPE.

${ }^{277}$ Nota-se que não há, nesse caso, a necessidade do pagamento ser pecuniário, sendo possível que o contrato estabeleça outras formas de remuneração.
} 
obra, o fornecimento e instalação de equipamentos ou a execução de obra pública. ${ }^{278}$

Denota-se com tais limitações o fato das PPPs serem ajustes contratuais voltados à realização de objeto de grande vulto financeiro, a ser amortizado no longo prazo.

Acerca do escopo da contratação, a impossibilidade da concessão ter como objeto único o fornecimento de mão-de-obra, o fornecimento e instalação de equipamentos ou a execução de obra pública, tem como finalidade embutir no contrato a obrigatoriedade de prestação de um serviço. Mais do que uma simples vedação, a Lei acaba por reforçar uma importante característica das PPPs: a possibilidade do escopo contratual congregar uma série de atividades diversas. Por meio de um único contrato, o Poder Público está autorizado a delegar um conjunto de ações diferentes entre si (obras, fornecimento de mãode-obra, fornecimento de bens, prestação de serviços) que passam a ser responsabilidade de apenas um concessionário.

Como a prestação dos serviços é elemento essencial para a delegação por meio de PPP, o pagamento da contraprestação será obrigatoriamente precedido da disponibilização do serviço ou de parcela fruível do serviço objeto do contrato de parceria públicoprivada. ${ }^{279}$ Isso significa que enquanto a totalidade ou parcela dos investimentos na construção ou aquisição de bens reversíveis não tiver sido efetuada a ponto de tornar ao

\footnotetext{
${ }^{278}$ Há, ainda, uma vedação que decorre do art. 28: “A União não poderá conceder garantia ou realizar transferência voluntária aos Estados, Distrito Federal e Municípios se a soma das despesas de caráter continuado derivadas do conjunto das parcerias já contratadas por esses entes tiver excedido, no ano anterior, a cinco por cento da receita corrente líquida do exercício ou se as despesas anuais dos contratos vigentes nos dez anos subsequentes excederem a cinco por cento da receita corrente líquida projetada para os respectivos exercícios" (grifo nosso). Percebe-se, com isso, que a despeito de não ser uma vedação expressa, acaba por limitar a contratação de PPP pelos Estados, Distrito Federal e Municípios, que dependem das transferências voluntárias da União. Para pequenos Municípios, essa limitação acaba por inviabilizar a contratação por meio de PPP. Entretanto, como a Lei das PPPs prevê a possibilidade de entidades da Administração pública direta e indireta, seria possível que a contratação se desse por meio, por exemplo, de eventual consórcio público formado por outros Municípios cujas capacidades financeiras não permitem realizar esse tipo de contratação sozinhos.

${ }^{279}$ Com a aprovação da Medida Provisória n ${ }^{\circ}$ 575/ 2012 a Lei passou a prever expressamente, já que antes havia interpretação possível que levava a mesma conclusão, duas situações: (i) a possibilidade de segregar a parcela do pagamento referente aos investimentos destinados à construção ou aquisição de bens reversíveis, da parcela referente à remuneração pela prestação dos serviços, prevista em lei específica; (ii) a realização do pagamento referente à parcela dos investimentos antes do término completo das obras, desde que garantida a proporcionalidade entre o montante repassado e as etapas concluídas (e, portanto, parcela fruível do objeto). Apenas para registro, em relação ao primeiro item, a finalidade de autorizar expressamente a separação do pagamento teve como mote a explicitação de um entendimento que vinha se consolidando em projetos de PPP no sentido de excluir da contraprestação pública o valor referente à construção ou à aquisição de bens reversíveis da base de cálculo para o recolhimento de alguns tributos, conforme disciplina do art. $6^{\circ}, \S 3^{\circ}$, incisos I e II da Lei das PPPs. Como exemplo de projetos que já abrangiam esse entendimento, é possível mencionar: (i) PPP do Complexo Datacenter, no âmbito do governo federal, promovida pelo Banco do Brasil e pela Caixa Econômica Federal; e a (ii) PPP para construção e operação de unidades de ensino no Município de Belo Horizonte.
} 
menos parte do objeto contratual fruível, não há pagamento do Poder Público ao parceiro privado.

Em decorrência dessa exigência, o concessionário acaba por ser incentivado a cumprir de maneira eficiente a etapa de construção ou aquisição de materiais, tendo em vista que sua remuneração está diretamente atrelada a essa eficiência. Seguindo a mesma lógica, ou seja, de incentivar a eficiência e a qualidade da prestação dos serviços, a Lei das PPPs estabelece a possibilidade da remuneração ser vinculada ao desempenho, conforme metas e padrões de qualidade e disponibilidade definidos no contrato.

Por diversas razões, que vão desde o momento da contraprestação até o elevado vulto dos investimentos e a vinculação da remuneração à prestação dos serviços, há um pressuposto de que a grande maioria dos projetos de PPP depende de financiamento para serem viabilizados pela iniciativa privada. Com o intuito de facilitar a obtenção de financiamento, a legislação trouxe inovações no sentido de permitir que: (i) o Poder Público ofereça garantia de que cumprirá suas obrigações de pagamento da contraprestação; ${ }^{280}$ (ii) haja transferência do controle da sociedade de propósito específico para seus financiadores (step-in right) ${ }^{281}$ (iii) os direitos emergentes da concessão sejam oferecidos em garantia aos financiadores etc. ${ }^{282}$

Outro aspecto a ser destacado em relação às PPPs relaciona-se à alocação de riscos entre o Poder Público e o parceiro privado. Segundo o art. $4^{\circ}$, inciso VI, da Lei das PPPs, o contrato de concessão deve especificar de modo objetivo a repartição de riscos entre as partes, inclusive os referentes a caso fortuito, força maior, fato do príncipe e álea econômica extraordinária, ${ }^{283}$ tradicionalmente alocados ao Poder Público por força do art. 65, inciso II alínea "d" da Lei federal n 8.666/1993.

Por fim, ao final do contrato, haverá a reversão dos bens ao Poder Público, tendo eles sido inicialmente cedidos ou construídos pelo parceiro privado no âmbito da

\footnotetext{
280 “Art. $8^{\circ}$ As obrigações pecuniárias contraídas pela Administração Pública em contrato de parceria público-privada poderão ser garantidas mediante: I - vinculação de receitas, observado o disposto no inciso IV do art. 167 da Constituição Federal; II - instituição ou utilização de fundos especiais previstos em lei; III - contratação de seguro-garantia com as companhias seguradoras que não sejam controladas pelo Poder Público; IV - garantia prestada por organismos internacionais ou instituições financeiras que não sejam controladas pelo Poder Público; V - garantias prestadas por fundo garantidor ou empresa estatal criada para essa finalidade; VI - outros mecanismos admitidos em lei." (Lei das PPPs)

${ }^{281}$ Art. $9^{\circ}, \S 1^{\circ}$, da Lei das PPPs.

${ }^{282}$ Art. $5^{\circ}, \S 2^{\circ}$, incisos II e III, da Lei das PPPs.

${ }^{283}$ Art. $5^{\circ}$, inciso III, da Lei das PPPs.
} 
concessão. $^{284}$

Realizado o panorama geral da Lei das PPPs e antes de dar início ao exame de sua aplicabilidade a projetos de regularização fundiária urbana de interesse social, cumpre mencionar, sinteticamente, as principais características abordadas: (i) são passíveis de delegação por meio de PPP serviços públicos, exclusivos e não exclusivos; (ii) há pagamento de contraprestação pública pela Administração; (iii) a contratação envolve elevado vulto de investimento, a ser realizado no longo prazo; (iv) há conjugação de diversas obrigações em um mesmo objeto, desde que haja a prestação de serviços; (v) a remuneração variável de acordo com o desempenho; (vi) maior repartição de riscos com a iniciativa privada, mitigando do risco de inadimplência do Poder Público; e (vii) há reversibilidade dos bens ao final do contrato.

Considerando tais características e confrontando-as ao objeto de estudo desta dissertação, é possível aproximar a regularização fundiária urbana de interesse social dos serviços públicos não exclusivos, por não ser um serviço industrial, divisível e não ser vedada a sua realização pela iniciativa privada, mas com conteúdo econômico, observado facilmente no mercado de provisão de moradias.

A despeito da existência de um conteúdo econômico, sendo, inclusive, a cobrança do usuário possível em tese, já que apenas algumas medidas expressamente o vedam, ${ }^{285}$ tal cobrança não pode desvirtuar o instituto, já que a finalidade dos processos de regularização fundiária é justamente envidar esforços para manter a população no local em que se situam, ainda que exceções sejam imperativas em algumas situações. ${ }^{286}$

Isso significa que, no âmbito das concessões patrocinadas, diante da impossibilidade de incluir a regularização fundiária urbana de interesse social como serviço delegável pela Lei federal $n^{\circ}$ 8.987/1995, restaria abarcar a regularização como obrigação do concessionário para a realização do objeto do contrato, ainda que o serviço ou a obra pública a serem delegados sejam outros. ${ }^{287}$ Situação similar ocorre, por exemplo, com a obrigação de realizar as atividades de execução material da desapropriação para a

\footnotetext{
${ }^{284}$ Aplicam-se às PPPs as hipóteses de extinção previstas na Lei federal no 8.987/1995.

${ }^{285}$ Há vedação expressa de cobrança: (i) Concessão de Uso Especial para Fins de Moradia; e (ii) Legitimação da posse.

${ }^{286}$ Como realocações diante da necessidade de urbanização ou de retirar população situada em área de risco.

${ }^{287}$ Apenas para exemplificar, não haveria qualquer ilegalidade em prever no contrato de concessão de obra a ser realizada em um terreno que está total ou parcialmente ocupado por população de baixa renda, a obrigação de o concessionário realizar a regularização fundiária, em seu conteúdo, antes de dar início à obra que será explorada para fins de remuneração.
} 
construção de uma rodovia, que pode ser atribuída ao concessionário.

Por outro lado, no caso da concessão administrativa, a regularização fundiária urbana de interesse social pode ser incluída no próprio objeto de delegação. Nesse caso, o concessionário pode ficar responsável por todas as etapas envolvidas no processo, desde o cadastramento até a urbanização da área, ou de parcela delas, desde que haja a inclusão da prestação de serviços por no mínimo 5 (cinco) anos, além da realização de obras de construção ou reforma de moradias e urbanização do assentamento. Nessas hipóteses, os serviços envolvidos podem estar relacionados aos processos de legalização do exercício da posse ou, ainda, à manutenção das áreas comuns do assentamento devidamente regularizado.

Sendo possível o enquadramento do projeto às diretrizes da Lei das PPPs, importa destacar de que modo esse formato de ajuste pode contribuir para reduzir os custos e viabilizar investimentos em projetos de regularização fundiária urbana de interesse social.

Para tanto, o contrato de concessão deve, de um lado, incluir no objeto da contratação a exploração de receitas alternativas, complementares, acessórias ou, ainda associar projetos que contribuam para a redução da contraprestação pública e, de outro, estabelecer uma remuneração que garanta ao privado um retorno compatível com os encargos e riscos assumidos para a realização do contrato.

Interessante notar que a reversão, nesse caso, ocorre apenas em relação às áreas públicas dentro do assentamento, já que a intenção com a regularização fundiária é melhorar as condições de moradia para a população que ali vive, para garantir sua permanência no local, com exceção das situações já mencionadas. Ainda que o parceiro privado realize investimento no assentamento como um todo, a reversibilidade ao Poder Público será apenas daquela correspondente à infraestrutura urbana estabelecida.

Cumpre notar que mesmo inexistindo reversão total das obras ao Poder Público, não nos parece possível que haja uma alteração da destinação de tais bens para fins diversos da habitação de interesse social que justificou a intervenção pública no local.

Diante do exposto, ainda que se considere como premissa que a realização de projetos de regularização fundiária urbana de interesse social apresenta um conteúdo econômico não atrativo para a iniciativa privada, a adoção do modelo das PPPs pode ser utilizada para viabilizar esse tipo de empreendimento, principalmente pelas seguintes vantagens: (i) permite a conjugação de diversos escopos em um único contrato, a serem 
realizados no longo prazo; (ii) contribui para a agilização da etapa de execução do plano de urbanização; (iii) autoriza o estabelecimento de receitas alternativas, acessórias e complementares, bem como a associação de projetos para dar viabilidade econômica ao empreendimento; (iv) prevê instrumentos que facilitam a captação de financiamento pela iniciativa privada; e (v) permite uma maior divisão de riscos entre o poder público e a iniciativa privada, se comparado aos tradicionais contratos de empreitada regidos pela federal $n^{0} 8.666 / 1993$.

\subsubsection{Concessão urbanística}

A concessão urbanística, diferentemente dos demais instrumentos analisados neste capítulo, não apresenta um quadro normativo federal consolidado que tipifique expressamente essa modalidade de concessão dentre as possíveis formas de delegação pelo poder público. No entanto, a análise conjunta do Decreto-Lei ${ }^{\circ} 3.365 / 1941$, da Lei federal $\mathrm{n}^{\circ}$ 6.766/1964, da Lei federal $\mathrm{n}^{\circ} 8.987 / 1995$ e do Estatuto da Cidade permite identificar a concessão urbanística como alternativa de ajuste para a realização de finalidades urbanísticas. $^{288}$

Previamente ao exame dos dispositivos que acabam por sustentar a compatibilidade $^{289}$ do instituto ao ordenamento jurídico, cumpre destacar que, conforme a própria terminologia indica, a concessão urbanística nada mais é do que a delegação à iniciativa privada de um direito de realizar um plano de urbanização para determinada área urbana, abrangendo uma série de atividades, em que o retorno do concessionário advém da

\footnotetext{
${ }^{288}$ Apesar de haver certa semelhança entre a "concessão urbanística" e a "concessão de obra pública", já que ambas importam em realização de obra por um delegatário do poder público, estamos de acordo com os ensinamentos de Marçal Justen Filho que identifica as seguintes diferenças: "Daí se infere que a concessão urbanística pode até apresentar parentesco com a concessão de obra pública, mas possui algumas peculiaridades diferenciadoras. [...] O primeiro reside na possibilidade da pluralidade e heterogeneidade de obras públicas comportadas no âmbito da contratação. [...] O tópico peculiar consiste na possibilidade de atribuição de encargos de outra natureza, que não configurem obra pública." (Concessões urbanísticas e outorgas onerosas. In: WAGNER JÚNIOR, Luiz Guilherme Costa (coord.). Direito público: estudos em homenagem ao professor Adilson Abreu Dallari. Belo Horizonte: Del Rey, 2004, p. 526).

${ }^{289}$ Adota-se o conceito de compatibilidade seguindo orientação do jurista Charles Eisenmann, que diferencia a compatibilidade da conformidade para fins de análise do conteúdo de legalidade ao qual a Administração Pública está sujeita. Segundo o autor, compatibilidade significa atuar sem contrariar a norma, enquanto que conformidade representa a atuação da Administração apenas quando autorizada expressamente pela norma. (EISENMANN, Charles. O direito administrativo e o princípio da legalidade. In: Revista de Direito Administrativo, Rio de Janeiro, v. 56, abr./jun., 1959, p. 47 et seq). No caso ora em análise, trata-se justamente de reconhecer a possibilidade de aplicação da concessão urbanística como decorrência da compatibilidade do instituto às normas existentes.
} 
própria exploração da urbanização empreendida. ${ }^{290}$

Para tanto, de pronto o concessionário depende da possibilidade de ingerência sobre a área delimitada para a execução das obras inseridas no âmbito do plano de urbanização. Daí surge uma primeira interface com o ordenamento jurídico, a necessidade de utilização da desapropriação urbanística prevista dentre as hipóteses de utilidade pública no art. $5^{\circ}$, alínea "i", do Decreto-Lei n ${ }^{\circ} 3.365 / 1941,{ }^{291}$ e no art. 44 da Lei federal n 6.766/1964. ${ }^{292}$

As finalidades inerentes à desapropriação urbanística, quais sejam a urbanização, requalificação urbanística, parcelamento ou edificação, a diferem da desapropriação administrativa usual, por duas razões centrais: (i) a aplicação do instituto por zona, inserida no plano de urbanização, e não necessariamente em face de um bem imóvel específico; ${ }^{293} \mathrm{e}$ (ii) a possibilidade de alienação dos bens expropriados após a desapropriação, já que é a própria destinação da área, após as devidas intervenções, que justifica o manejo da expropriação. ${ }^{294}$ Sendo assim, se de um lado a desapropriação urbanística garante que determinada região, e não apenas um bem imóvel, seja desapropriada para fins de urbanização, de outro o próprio instituto prevê a possibilidade de exploração econômica dos bens desapropriados para fins de urbanização.

A concessão urbanística, portanto, apenas introduz a figura do delegatário para a execução do plano de urbanização e posterior exploração econômica dos bens envolvidos no processo, em total congruência com a concessão de obra pública, sendo, portanto,

\footnotetext{
${ }^{290}$ Segundo José Afonso da Silva, a concessão urbanística caracteriza-se por ser: "instrumento de outorga, a particulares, de atividade urbanística, mormente na execução de planos ou projetos de reurbanização ou de renovação urbana, elaborado pelas Municipalidades.” (SILVA, op. cit., 1981, p. 375.)

291 “Art. $5^{\circ}$ i) a abertura, conservação e melhoramento de vias ou logradouros públicos; a execução de planos de urbanização; o parcelamento do solo, com ou sem edificação, para sua melhor utilização econômica, higiênica ou estética; a construção ou ampliação de distritos industriais." (Decreto-Lei n 3.365/1941) (grifo nosso).

292 “Art. 44. O Município, o Distrito Federal e o Estado poderão expropriar áreas urbanas ou de expansão urbana para reloteamento, demolição, reconstrução e incorporação, ressalvada a preferência dos expropriados para a aquisição de novas unidades." (Lei federal n 6.766/1964).

293 Conforme José Afonso da Silva: “A desapropriação urbanística, ao contrário, é compreensiva e generalizável, atingindo áreas e setores completos, retirando os imóveis, aí abrangidos, do domínio privado, para afetá-los ao patrimônio público, para depois serem devolvidos ao setor privado, uma vez urbanificados ou reurbanizados." (SILVA, op. cit., 1981, p. 538).

294 Adilson de Abreu DALLARI esclarece: "Tem-se entendido a doutrina, com perfeito respaldo jurisprudencial, que, nos casos expressamente previstos na legislação que disciplina a desapropriação, é perfeitamente possível que o Poder Público desaproprie um bem, pague o valor correspondente à indenização e, depois, subsequentemente, entregue o mesmo bem a outro particular, que lhe dará a destinação que serviu de fundamento para o exercício da competência expropriatória." (DALLARI, Adilson de Abreu. Concessões urbanísticas. In: Fórum de Direito Urbano e Ambiental - FDUA, Belo Horizonte, ano 5, n. 27, maio/jun. 2006. Disponível em: <http://www.bidforum.com.br/bid/PDI0006.aspx?pdiCntd = 35920>. Acesso em: 22 set. 2012)
} 
regulada, no que couber, pela Lei federal $n^{\circ} 8.987 / 1995 .^{295}$

O Estatuto da Cidade, em complemento, estabelece as diretrizes que devem conduzir a política urbana e, consequentemente, a aplicação de instrumentos voltados ao atingimento de seu objetivo, qual seja ordenar o pleno desenvolvimento das funções sociais da cidade e da propriedade urbana. Desse modo, ainda que a concessão urbanística não tenha sido disciplinada expressamente como instrumento da política urbana pelo Estatuto da Cidade, sua realização pelo Poder Público deve ser conduzida de forma harmônica com os princípios que orientam a política urbana como um todo, previstos no art. $2^{\circ}$ do Estatuto da Cidade.

Não obstante a concessão urbanística ter aspectos que a aproximam das operações urbanas consorciadas, como a existência de um plano de urbanização para área delimitada prevendo o conjunto de intenções com a participação dos envolvidos, ${ }^{296}$ ambos os institutos não são fungíveis entre si, no nosso entender.

Isso ocorre porque, na concessão urbanística, há a delegação, por meio de contrato, da execução de um plano de urbanização para determinada área urbana a um concessionário que irá explorar economicamente os benefícios da urbanização, por prazo determinado que seja suficiente para a amortização dos investimentos, enquanto que na operação urbana consorciada o papel do Poder Público é de elaboração e coordenação da execução do plano, recolhendo ele próprio as contrapartidas decorrentes da flexibilização das normas de uso e ocupação do solo.

Ainda assim, entretanto, na ausência de uma disciplina específica federal, a concessão urbanística deve seguir, de acordo com o que couber, as normas aplicáveis as operações urbanas consorciadas, notadamente no que se refere à elaboração do plano de urbanização.

O principal obstáculo para a inclusão de processos de regularização fundiária

\footnotetext{
${ }^{295}$ Em que pese o art. $2^{\circ}$ a Lei federal n 8.987/1995 ter definido apenas duas modalidades de concessão, a concessão de serviço público e a concessão de serviço público precedida de obra pública, a concessão apenas de obra pública, sem seu atrelamento obrigatório a prestação de um serviço público, está compreendida no art. $1^{\circ}$ da mesma Lei federal $n^{\circ}$ 8.987/1995. Além disso, a doutrina é uníssona ao identificar essa possibilidade de ajuste contratual, conforme se depreende dos seguintes trechos selecionados: "Hoje já se reconhece a existência desse contrato, como modalidade autônoma em relação ao em relação ao de concessão de serviço público; ele tem por objeto a execução de um obra, sendo secundária a prestação ou não de um serviço público." (DI PIETRO, op. cit. 2005, p. 287). "A exploração de obra pública, decorrente de concessão dela (sabe-se qualquer pessoa mediocremente versada na matéria), configura concessão de obra pública, e não concessão de serviço público. Assim, a lei fez evidente confusão." (MELLO, op. cit., p. 671).

296 Tais semelhanças são apontadas por Adilson de Abreu Dallari (DALLARI, op. cit., 2006).
} 
urbana de interesse social em contratos de concessão urbanística decorre da necessidade de comercialização dos bens após a execução do plano de urbanização de modo a viabilizar a exploração econômica a ser empreendida pelo concessionário. Tal necessidade de exploração econômica, porém, não pode ser interpretada de maneira inconsequente.

A concessão urbanística tem uma finalidade que vai muito além da possibilidade de exploração econômica da área urbanizada ou requalificada. Em verdade, a possibilidade de exploração econômica caracteriza-se como meio para atingir ao fim desejado, qual seja, melhorias urbanísticas em áreas delimitadas da cidade. Tal finalidade está inseria em um contexto legal que prevê, dentre outras diretrizes, as seguintes: (i) a justa distribuição dos beneficios e ônus decorrentes do processo de urbanização; e (ii) a cooperação entre os governos, a iniciativa privada e os demais setores da sociedade no processo de urbanização, em atendimento ao interesse social.

Assim, a inclusão de processos de regularização fundiária urbana de interesse social no plano de urbanização e, consequentemente, do contrato de concessão urbanística poderia ser uma das formas de garantir a compatibilidade do instituto com as diretrizes da política urbana, atendendo ao interesse social, já que parte dos recursos arrecadados no âmbito da exploração econômica seriam utilizados para subsidiar projetos de interesse social diretamente relacionados aos processos de urbanização.

Assim, a vantagem para o Poder Público em incluir a regularização fundiária de interesse social no contrato de concessão urbanística está em viabilizar investimentos no setor sem ter que, com isso, alocar recursos financeiros diretamente do orçamento público, e ao mesmo tempo contribuir para que o instrumento atinja as finalidades de interesse social que orientam a política urbana.

\subsection{Síntese conclusiva do capítulo}

Este capítulo apresentou de que forma seria possível utilizar instrumentos, específicos da política urbana ou não, para viabilizar investimentos em projetos de regularização fundiária urbana de interesse social, partindo da premissa que tais projetos, por si só, tem pouca ou nenhuma capacidade de serem autossustentáveis do ponto de vista econômico-financeiro.

Sinteticamente, em relação aos instrumentos examinados, pode-se apontar distintos 
aspectos. O primeiro refere-se ao exame do instituto da Operação Urbana Consorciada, que evidencia a possibilidade de utilização do mecanismo para alavancar recursos, pecuniários ou não, por meio da cobrança de contrapartidas exigidas dos beneficiários da operação, sendo a aplicabilidade de tais recursos em processos de regularização fundiária urbana de interesse social uma decorrência da interpretação das diretrizes do Estatuto da Cidade, além de garantir a inclusão da população de baixa renda como beneficiária da urbanização decorrente da operação urbana.

Outro aspecto diz respeito à outorga onerosa do direito de construir, pois contribui para a arrecadação de recursos, pecuniários ou não, que apresentam como possível destinação a regularização fundiária urbana de interesse social, tendo o diferencial de poderem ser aplicados em qualquer local da área urbana;

O convênio é instrumento apto para viabilizar recursos, à medida que permite a captação interfederativa de recursos, financeiros, humanos e de bens, para a viabilização dos mais variados projetos, cabendo, nesse rol, a regularização fundiária urbana de interesse social.

No âmbito do SNHIS, o repasse de recursos para projetos de regularização fundiária urbana de interesse social, ainda que possível, acaba por ser limitada em função: (i) da ausência de repasse automático que envolva diretamente programas de regularização fundiária de interesse social; (ii) da impossibilidade dos Estados, Distrito Federal e Municípios formularem os programas de modo diverso do estabelecido na esfera federal; (iii) da priorização de outros programas de governo na esfera federal.

Os consórcios públicos podem ser utilizados como forma de repartição de encargos e custos entre mais de um ente da federação para a realização de projetos de regularização fundiária urbana de interesse social, além de ser alternativa aplicável para a solução conjunta do problema em regiões metropolitanas, onde há concentração de irregularidades passíveis de serem inseridas no objeto da regularização fundiária urbana de interesse social;

A adoção do modelo das PPPs pode ser utilizada para viabilizar investimentos em projetos de regularização fundiária urbana de interesse social, pelas seguintes razões: (i) permite a conjugação de diversos escopos em um único contrato, a serem realizados no longo prazo; (ii) contribui para a agilização da etapa de execução do plano de urbanização; (iii) autoriza o estabelecimento de receitas alternativas, acessórias e complementares, bem 
como a associação de projetos para dar viabilidade econômica ao empreendimento; (iv) prevê instrumentos que facilitam a captação de financiamento pela iniciativa privada; e (v) permite uma maior divisão de riscos entre o poder público e a iniciativa privada, se comparado aos tradicionais contratos de empreitada regidos pela Lei federal $n^{\circ}$ 8.666/1993.

Por fim, a concessão urbanística, por meio da possibilidade de exploração econômica da área concedida após a execução do plano de urbanização e da necessidade do instituto ser utilizado de modo compatível com as diretrizes da política urbana estabelecidas no Estatuto da Cidade, acaba por permitir a viabilização de investimentos na regularização fundiária urbana de interesse social. 


\section{CAPÍtULLO V \\ ANÁLISE CRÍTICA DA REGULARIZAÇÃO FUNDIÁRIA URBANA DE INTERESSE SOCIAL}

Nos capítulos anteriores, apresentou-se o instituto da regularização fundiária urbana de interesse social enquanto processo, fundado na garantia da função social da propriedade urbana e no direito à moradia, que teve seu conteúdo ampliado pela legislação de modo a congregar um conjunto de ações complexas que envolvem desde a legalização do exercício da posse até a urbanização, a serem implementadas por meio de um extenso rol de instrumentos jurídicos, aplicados de acordo com a situação concreta da irregularidade.

O objetivo deste capítulo, no entanto, é a identificação do processo de regularização fundiária urbana de interesse social, enquanto alternativa de atuação do Poder Público para incluir a população de baixa renda, que vive de maneira ilegal, na cidade formal, examinando se tal finalidade do instrumento apresenta-se de fato concretizada com a sua implementação.

Salienta-se que, do ponto de vista metodológico, optou-se por não abordar um estudo de caso específico, diante da dificuldade de apenas um caso sintetizar a problemática como um todo, tendo em vista que os aspectos críticos podem ocorrer tanto internamente, nesse caso, com variações de intensidade em cada situação concreta, como externamente aos processos de regularização fundiária urbana de interesse social, conforme será demonstrado.

Por tais razões, a análise será empreendida de modo a considerar problemáticas comuns entre os processos de regularização fundiária urbana de interesse social, que se apresentam com intensidades diversas a depender da situação concretamente observada, e acabam por afetar em alguma medida a efetividade do instituto.

O capítulo apresentará, em cada um dos aspectos problemáticos suscitados, as formas de mitigação de tais problemas, seja por meio dos mecanismos que a própria legislação tratou de abordar ou da identificação de outros aspectos que podem contribuir para o enfrentamento das dificuldades, ainda que não expressamente previstos na legislação. 


\subsection{Problemáticas internas}

Consideram-se problemáticas internas aos processos de regularização fundiária urbana de interesse social aquelas que de alguma maneira dificultam sua efetividade por razões inerentes ao processo, sejam elas decorrentes: (i) da concepção adotada; (ii) da complexidade no desencadeamento do processo; ou, ainda, (iii) dos custos nele envolvidos.

A primeira delas, que decorre da adoção de uma concepção restrita do instituto da regularização fundiária urbana de interesse social, pode ser observada a partir da experiência disseminada na década de 1990 pelo Banco Mundial, tendo como fundamento a teorização de Hernando de Soto, no sentido de separar a legalização do exercício da posse da urbanização e promover a conferência de títulos de propriedade em massa, adotada por alguns países na America Latina, notadamente no Peru e no México.

Supunha-se, em síntese, que a política da conferência de títulos de propriedade à população de baixa renda que vivia de modo ilegal seria capaz de introduzi-la no mercado formal de crédito e financiamento, fato que acabaria por culminar em dois resultados diretos: (i) facilitação de investimento do próprio morador na melhoria das condições de moradia; e (ii) redução considerável do mercado informal de realização de negócios em geral, encontrado nos assentamentos ilegais. Ambas as consequências contribuiriam diretamente para o fomento da economia do país, transformando o chamado por ele de "capital morto" em capital revertido em benefício desta, já que a informalidade chegava a movimentar cerca de U\$9,3 bilhões que não estariam sendo usufruídos pelo mercado formal do país como um todo. ${ }^{297}$

Seguindo a orientação do teórico, o Peru deu início a uma massiva política de regularização fundiária exclusivamente dominial que culminou em aproximadamente 1.134.000 (um milhão cento e trinta e quatro mil) títulos outorgados, no período de 1996 até 2000 , à população que ocupava áreas de modo irregular. ${ }^{298}$ Entendia-se que a transformação da posse ilegal em propriedade privada, permitiria que o título fosse utilizado como garantia para empréstimos e financiamentos, fato que, por sua vez,

\footnotetext{
${ }^{297}$ FERNANDES, Edésio. La influencia de El misterio del capilal de Hernando de Soto. In: SMOLKA, Martin O. e MULlAHY, Laura. Perspectivas urbanas, Temas críticos en políticas de suelo en América Latina. Cambridge: Lincoln Institute of Land Police, 2007, p. 110.

${ }^{298}$ CALDERÓN, Julio. El misterio del crédito. In: SMOLKA, Martin O. e MULLAHY, Laura. Perspectivas urbanas, Temas críticos en políticas de suelo en América Latina. Cambridge: Lincoln Institute of Land Police, 2007, p.118.
} 
alimentaria a economia por meio da geração de renda a famílias até então excluídas do mercado imobiliário do país. ${ }^{299}$ Contudo, o esperado impacto positivo na economia do Peru com a política de transformação da posse irregular em propriedade privada não obteve o êxito esperado.

A pouca relação que se estabelece entre a concessão de títulos de propriedade e o acesso ao crédito, tendo como fundamento o ocorrido no Peru, foram bem sintetizadas por Julio Caldéron, que identificou as razões pelas quais a teoria não logrou o êxito esperado: (i) o país passou por uma recessão econômica entre 1998 e 1999 que afetou os bancos privados, dificultando a concessão de crédito; (ii) a aplicação de recursos próprios para a melhoria das condições físicas das residências ilegais supera a dos empréstimos bancários; (iii) a concessão de empréstimo em bancos privados se baseia mais no fluxo de renda do beneficiário e na estabilidade desse fluxo do que no título de propriedade; e (iv) a principal fonte de empréstimos advêm de entidades públicas ou é realizada com subsídio público, sendo que, nesses casos, se constata o empréstimo tanto em situações regularizadas como irregulares.

Além de tais características, observa o autor que a política de concessão de títulos de propriedade em massa acabou por manter a população de baixa renda vulnerável às pressões do mercado imobiliário sendo frequentemente expulsas para regiões ainda mais periféricas, após a obtenção da propriedade e a valorização inerente a tal formalização, já que os valores, como em qualquer outro seguimento do mercado de terras, refletem a expectativa de uso futuro do terreno. ${ }^{300}$

Com isso, restou evidenciado que apenas a concessão de títulos de propriedade como expressão da regularização fundiária de interesse social não tem o condão de integrar a população na cidade formal e não proporciona como decorrência lógica a melhoria das condições de moradia, conforme esperado pelo teórico Hernando de Soto. Essa concepção pode servir, inclusive, como facilitador para as pressões de mercado, que acabam por culminar na expulsão da população do local, após a obtenção da propriedade, e consequente expansão da irregularidade para outros locais da cidade.

Buscando evitar ambas as consequências desastrosas para o que se propõe com a aplicação do instituto da regularização fundiária urbana de interesse social, quais sejam a

\footnotetext{
299 SPINAZZOLA, Patrícia Cezário Silva. Impactos da Regularização Fundiária no Espaço Urbano. Dissertação de mestrado. Faculdade de Arquitetura e Urbanismo. Universidade de São Paulo, 2008, p. 20.

${ }^{300}$ CALDERÓN, Julio. Mercado de tierras urbanas, propriedade y probreza. Lima, Lincon Instituto of Land Policy. Sinco Editores, 2006.
} 
ausência de melhoria nas condições de moradia e a expulsão posterior da população, o ordenamento brasileiro contribuiu de duas maneiras diversas.

Uma das alternativas foi considerar a legalização da posse apenas como uma das etapas da regularização fundiária a ser integrada também à urbanização, conforme previsto no ordenamento jurídico brasileiro desde 2001 com o Estatuto da Cidade, ${ }^{301}$ e adotado pelo governo federal já no primeiro programa voltado à regularização fundiária urbana de interesse social, o Programa Nacional de Regularização Fundiária Sustentável iniciado em 2003, sendo que as primeiras experiências de regularização fundiária de interesse social realizadas por Municípios, até mesmo antes da Constituição Federal de $1988^{302}$, compreendiam tanto a legalização da posse quanto a urbanização.

Por outro a legislação criou as Zonas Especiais de Interesse Social, que acabam por demarcar determinada área para o atendimento da população de baixa renda. Se por um lado, tenta-se evitar que as pressões do mercado imobiliário desvirtuem o processo de regularização fundiária empreendido, por meio da fixação da destinação da área para ações de interesse social, por outro, a medida deixa explícita a incapacidade ou a dificuldade de incluir de fato essa população nas áreas residenciais "não especialmente destinadas ao interesse social".

Outros são os impasses inerentes aos processos de regularização fundiária urbana de interesse social que acabam por impactar negativamente sua efetividade, em menor ou maior escala a depender do caso concreto. Um exemplo é a lentidão característica dos processos de legalização do exercício da posse, causada por diversos fatores que permeiam os processos administrativos, notadamente o registro dos títulos, e o Judiciário, quando envolvido em alguma das fases do processo de regularização fundiária de interesse social. ${ }^{303}$

Essa problemática é de certo modo passível de ser extraída da análise da própria legislação pátria. Não sem razão, algumas das Leis relacionadas ao instituto da regularização fundiária urbana de interesse social tiveram que alterar a Lei federal $\mathrm{n}^{0}$ 6.015/1973, que dispõe sobre os registros públicos, para prever expressamente a obrigatoriedade de registro de títulos decorrentes de processos de regularização

\footnotetext{
${ }^{301}$ A análise detalhada do tema foi empreendida no primeiro capítulo da dissertação.

302 As experiências nos Municípios de Recife e Diadema encontram-se expostas no item da dissertação referente às ZEIS.

${ }^{303}$ WARD, Peter M. Foro internacional sobre regularización e mercados de la tierra. In: SMOLKA, Martin O.; MULlAHY, Laura. Perspectivas urbanas, Temas críticos en politicas de suelo en América Latina. Cambridge: Lincoln Institute of Land Police, 2007, p. 101.
} 
fundiária, ${ }^{304}$ reforçando a inexistência de opção do cartório acerca da aceitação do título. A gratuidade $^{305}$ de tais registros é outra característica que tem o propósito de torná-los acessíveis à população beneficiada da regularização fundiária de interesse social, caracterizada pela reduzida capacidade econômica.

Seguindo essa linha e buscando retirar, quando possível, o judiciário do processo de regularização fundiária urbana de interesse social, o novo marco normativo do instituto, a Lei do Programa Minha Casa Minha Vida, cria um procedimento inteiramente administrativo, sem, portanto, o envolvimento do judiciário em qualquer das etapas, para a realização regularização fundiária de interesse social, conforme se depreende da análise dos institutos da demarcação urbanística e da legitimação da posse.

Outra característica relaciona-se com o nível de segurança jurídica decorrente da regularização do exercício da posse, já que não há necessariamente uma alteração no nível de segurança a depender da ocupação e da situação da irregularidade. ${ }^{306}$ Isso porque, diante da demora na obtenção do título aliada a outros fatores, tratados adiante, é comum haver intervenções públicas mesmo antes da legalização da posse, fato que acaba por contribuir para a consolidação da ocupação. Por sua vez, uma ocupação consolidada que tenha acesso a algum nível de serviço público afasta, em alguma medida, o risco real de despejo forçado, fazendo com que a sensação de segurança ocorra de modo independente da existência ou não de título formal que reconheça a legalidade do exercício da posse. ${ }^{307}$

Cabe ainda destacar como aspecto interno ao processo de regularização fundiária de interesse social que o custo de urbanizar uma área já ocupada é muito superior ao custo de urbanizar previamente uma área a ser ocupada no futuro, ${ }^{308}$ por uma razão muito simples e

\footnotetext{
304 “Art. 167 - No Registro de Imóveis, além da matrícula, serão feitos: I - o registro: [...] 28) das sentenças declaratórias de usucapião; (Redação dada pela Medida Provisória $n^{\circ}$ 2.220, de 2001); [...] 37) dos termos administrativos ou das sentenças declaratórias da concessão de uso especial para fins de moradia; (Redação dada pela Medida Provisória $n^{\circ} 2.220$, de 2001) [...] 39) da constituição do direito de superfície de imóvel urbano; (Incluído pela Lei $\mathrm{n}^{\circ} 10.257$, de 2001) 40) do contrato de concessão de direito real de uso de imóvel público; (Redação dada pela Medida Provisória ${ }^{\circ}$ 2.220, de 2001) 41) da legitimação de posse; (Incluído pela Lei $n^{\circ} 11.977$, de 2009); 42) da conversão da legitimação de posse em propriedade, prevista no art. 60 da Lei no 11.977, de 7 de julho de 2009; (Incluído pela Lei no 12.424, de 2011)." (Lei federal n ${ }^{\circ} 6.015 / 1973$ ). ${ }^{305}$ Art. $12, \S 2^{\circ}$ do Estatuto da Cidade.

${ }^{306}$ WARD, op. cit., p. 99.

${ }^{307}$ Nessa esfera, destaca também Jean-Louis Van Gelder: “Once the first official services or infrastructure) enter a settlement, residents interpret it as implying, or at least contributing to, official recognition, which adds to both feelings of legitimacy and perceptions of tenure security, knowing that it is unlikely that the state will destruct infrastructure it has contributes to itself." (Tales of Deviance and Control: On Space, Rules, and Law in Squatter Settlements. In: Law and Society Review, v.44, n.2, 2010, p. 257).

${ }^{308}$ No caso de ocupações irregulares, a lógica da ocupação do solo urbano é completamente invertida, já que pela legislação, a ocupação é a última etapa de uma sequência de ações que se inicia com a implementação
} 
que decorre do próprio histórico das ocupações irregulares: as áreas ocupadas irregularmente são, em regra, inadequadas para o uso, o que acaba por dificultar a implementação da infraestrutura, demandando maiores investimentos. ${ }^{309}$

Nesse sentido, o programa Favela-Bairro realizado no Rio de Janeiro, reconhecido internacionalmente como sendo de êxito em termos de urbanização, ${ }^{310}$ teve, no período de 1994 a 1997, um dispêndio de recurso equivalente a U\$ 300.000 .000 (trezentos milhões de dólares). ${ }^{311}$

A constatação de que o custo de urbanizar uma área já ocupada é superior, aliada aos princípios da Administração Pública que buscam atuar de maneira econômica e eficiente, acabam por elevar a regularização fundiária urbana de interesse social ao caráter de exceção, a ser utilizado apenas em situações já consolidadas, e, ainda, por tornar imperativa a necessidade de a Administração fazer uso das formas de ajustes que contribuam para a viabilização de investimentos no setor, conforme destacado no capítulo anterior.

Diante do apresentado, é possível sintetizar as seguintes conclusões acerca dos aspectos internos aos processos de regularização fundiária urbana de interesse social que acabam comprometendo a sua efetividade: (i) a legislação brasileira apresenta um avanço ao considerar a regularização fundiária de interesse social um processo que compreende a dimensão da regularização dominial e a urbanização das ocupações irregulares; (ii) há impasses inerentes aos processos de regularização que a legislação cuidou de mitigar, como ocorre com cartórios e com o judiciário; e (iii) os custos elevados para a urbanização de assentamentos irregulares reforçam a necessidade desse tipo de medida ser adotada pelo Poder Público como exceção para ampliar a sua atuação no sentido de viabilizar

de infraestrutura urbana. (DAMASIO, Cláusio P. e SMOLKA, Martin O. El Urbanizador Social: un experimento en políticas del suelo en Porto Alegre. In: SMOLKA, Martin O. e MULLAHY, Laura, Perspectivas urbanas, Temas críticos en políticas de suelo en América Latina, Cambridge: Lincoln Institute of Land Police, 2007, p. 135)

${ }^{309}$ Ao analisarem a Área Metropolitana da Cidade do México (AMCM), Afonso Iracheta Cenecorta e Martim O. Smolka constatam: "Do ponto de vista econômico, o padrão disperso dos assentamentos ao longo da franja metropolitana, em especial os ilegais, majoritariamente em locais inadequados, e o déficit na infraestrutura multiplicam os custos de urbanização em relação a um desenvolvimento planejado, com uma consequente distribuição ineficaz dos recursos sociais para o desenvolvimento urbano. Um exemplo claro desse processo ;e o Valle de Chalco dentro da AMCM, A introdução de serviços básicos representou investimentos várias vezes maiores que os usualmente necessários para localizações normais, porque esse imenso assentamento ilegal está localizado em terra quase sem capacidade de mecânica de construção." (O Paradoxo da Regularização Fundiária: acesso à terra servida e pobreza urbana no México. In: Cadernos IPPRU, Rio de Janeiro, ano XIV, n.1, jan/jul, 2000, pp.100-101).

${ }^{310}$ Indicado pela ONU como exemplo a ser seguido por outros países no Relatório Mundial das Cidades 2006/07. (disponível em: < http://www0.rio.rj.gov.br/habitacao/favela_bairro.htm>. Acesso em: 28 nov. 2012).

${ }^{311}$ WARD, op. cit., p. 101. 
investimentos por meio da utilização de outros modelos de ajuste.

\subsection{Problemáticas externas}

Seguindo na apresentação dos resultados indesejados de processos de regularização fundiária urbana de interesse social, que acabam por comprometer sua efetividade, importa trazer à baila as principais problemáticas identificadas do ponto de vista externo ao instituto: (i) a ampliação das ocupações irregulares do espaço urbano como consequência de processos de regularização fundiária urbana de interesse social; e (ii) a ausência de continuidade da ações voltadas à regularização, bem como sua utilização para fins eleitoreiros.

No tocante ao primeiro aspecto, observa-se que a mera sinalização da Administração Pública no sentido de promover a regularização fundiária acaba por contribuir para a proliferação de ocupações ilegais, servindo de estímulo a ela, como bem destaca Martim O. Smolka:

No Brasil, por exemplo, à eleição da prefeita Luiza Erundina, do Partido dos Trabalhadores, na cidade de São Paulo, segue uma explosão de ocupações e/ou invasões - muitas usadas como estratégia para a conquista de um terreno regularizado... O mesmo aconteceu como consequência das promessas de companha de Leonel Brizola no Rio, ou do Triunfo de Miguel Arraes como governador de Pernambuco, em 1986 - "que se traduziu em treze invasões de terras em pouco mais de um mês". ${ }^{312}$

Se a mera sinalização no sentido de promover regularização fundiária importa na geração de mais irregularidades, isso ocorre como decorrência da necessidade de se combinar políticas de prevenção à irregularidade e não apenas regularizar as situações ilegais. $\mathrm{O}$ oferecimento de alternativas de acesso ao mercado formal pela população de baixa renda acaba sendo elemento externo essencial para o efetividade da implementação de processos de regularização fundiária urbana de interesse social.

Em adendo, o histórico da implementação de processos de regularização fundiária urbana de interesse social demonstra que a realização de investimento público, direta ou indiretamente, em infraestrutura urbana nas ocupações irregulares, apresenta diversas características, ${ }^{313}$ dentre as quais se destacam especialmente: (i) a descontinuidade dos

\footnotetext{
${ }^{312}$ SMOLKA, Martim O. Regularização da ocupação do solo urbano: a solução que é parte do problema, o problema que é parte da solução. In ALFONSIN, Betânia de Moraes, e FERNANDES, Edésio, A lei e a ilegalidade na produção do espaço urbano. Belo Horizonte: Del Rey, 2003, p. 279.

${ }^{313}$ WARD, op. cit., 99.
} 
programas de governo voltados à solução da problemática da irregularidade; ${ }^{314}$ e (ii) a associação das intervenções à realização de práticas clientelistas em períodos eleitorais. ${ }^{315}$

Como forma de mitigar ambas as consequências, o Estatuto da Cidade apresenta clara diretriz no sentido de inserir os processos de regularização fundiária urbana de interesse social no âmbito do planejamento urbano, expresso por meio do Plano Diretor ou lei correspondente, a ser empreendido de modo democrático. Entretanto, a nosso ver, mais do que inserir no Plano Diretor, medida que acaba sendo demasiadamente genérica e limitada àquilo que cabe ao Plano Diretor, adiante abordado, é importante que haja uma procedimentalização ${ }^{316}$ no âmbito da atuação administrativa para a escolha das áreas que serão efetivamente beneficiadas.

Pontuados os aspectos externos que afetam a efetividade da realização de processos de regularização fundiária urbana de interesse social, passamos ao exame de cada uma das soluções apresentadas.

\subsubsection{A combinação de políticas preventivas}

Conforme demonstrado, quando a consequência dos processos de regularização fundiária urbana de interesse social passa a ser o aumento da irregularidade no espaço urbano,

\footnotetext{
${ }^{314}$ Acerca do tema, destaca Edésio Fernandes: “As intervenções do Poder Público através de programas de regularização têm se dado de maneira isolada, setorial, sem que haja a devida integração entre tais programas e o contexto mais amplo das políticas urbanas [...]." (FERNANDES, op. cit., 2004, p. 357).

${ }^{315}$ A frequente associação entre políticas de regularização fundiária e práticas clientelistas foi ressaltada por Jean-Luis Van Gelder, ao estudar os assentamentos informais em Buenos Aires: "Perhaps even more important is a settlement's dependency on state actors and agencies for its development and the fact that tenure security alqays remains partial without full legality, as sociopolitical pacts against eviction and official toleration of informal occupations are vulnerable to change (Van Gelder 2010). The ambiguity that characterizes this situation in Buenos Aires, leads processes of state intervention to be subject to clientelist practices in wich servicing and settlement upgrading are presented as favors granted to settlers, instead of being an expression of their rights." (GELDER, op. cit., p. 261). No mesmo sentido, mas agora voltado à realidade brasileira, Ana Cláudia Duarte Cardoso afirma: "Em termos práticos, quanto maior o assentamento informal, maiores são as chances de este ser rapidamente melhorado, à medida que oferece um maior número de votos (Leeds, citado em Gilbert \& Gugger, 2000, p. 149)" (Assentamentos informais e a pobreza urbana. Belém em foco. In: VALENÇA, Márcio Moraes (org.), Cidade (i)legal, Rio de Janeiro: Mauad X, 2008, p. 184).

${ }^{316} \mathrm{O}$ termo "procedimentalização" é adotado em sentido amplo, correspondendo ao gênero no qual o processo é espécie. Isso porque, pretende-se analisar tanto as ações a serem desempenhadas pela própria Administração Pública para assegurar a continuidade das iniciativas de regularização fundiária para além de um único governo, como o envolvimento dos sujeitos interessados na tomada de decisão. Daí porque a adoção do termo "processo" poderia reduzir a abrangência da análise. Acerca da diferença entre ambos os conceitos, Odete Medauar ensina: "Essa evolução culmina, principalmente, na concepção do procedimentogênero, como representação da passagem do poder em ato. Nesse enfoque, o procedimento consiste na sucessão necessária de atos encadeados entre si que antecede e prepara o ato final. O procedimento se expressa em processo se for prevista também a colaboração de sujeitos, sob prisma contraditório." ( $A$ processualidade no direito administrativo. São Paulo: Revista dos Tribunais, $2^{\text {a }}$ ed., 2008, p. 43.)
} 
fica evidenciada a ausência de alternativas de acesso ao solo urbano pela via da legalidade.

Isso decorre porque a regularização fundiária tem uma finalidade que lhe é inerente no sentido de contribuir de maneira curativa para a problemática das ocupações irregulares constituídas. Como seu conteúdo é apenas curativo, o instituto não tem a capacidade de, por si só, reverter o processo de acesso ilegal ao solo urbano, sendo imprescindível para a sua efetividade que haja uma combinação com políticas voltadas a prevenir o acesso ilegal ao solo e às edificações urbanos. ${ }^{317}$

Identificando a problemática de sinalizar a intenção de promover a regularização fundiária, é interessante mencionar a experiência vivenciada em Aguascalientes, no México, trazida por Martim O. Smolka, na qual a administração local anunciou que não regularizaria nenhum assentamento entre 1993 e 1998 e fortaleceu a fiscalização no sentido de evitar o parcelamento irregular. Tal decisão foi complementada por uma política de reserva territorial para provisão pública e, com preço reduzido do solo, atingindo uma redução das ocupações irregulares que chegaram a menos de $1 \% .{ }^{318}$

Daí a importância da regularização fundiária urbana de interesse social ser combinada com políticas preventivas que viabilizem a oferta de moradias para a população de baixa renda no âmbito do mercado formal.

Nesse sentido, destaca, com precisão, Edésio Fernandes:

Desde uma perspectiva ampla, o desenvolvimento informal é um problema. Esse problema deve ser enfrentado de duas maneiras principais, que devem ser necessariamente combinadas:

- políticas preventivas que articulem políticas fundiária com políticas urbanas, habitacionais, ambientais e fiscais, sobretudo na esfera local; envolvendo terras vazias de propriedade privada e pública, especialmente áreas centrais e imóveis vazios e subutilizados privados ou públicos, bem como envolvendo as administrações públicas em todas as esferas governamentais, o setor privado, as comunidades organizadas (cooperativas, ONGs, movimentos sociais, etc.) e outros setores como a universidade para dar assistência técnica e jurídica às administrações municipais e às comunidades; $\mathrm{e}$

- políticas curativas de regularização fundiária de interesse social de

\footnotetext{
${ }^{317}$ Segundo Martim O. Smolka, "o dilema é que não regularizar, simplesmente, não é uma opção política (senão social e humanitária). O desafio apresenta-se em como regularizar sem alimentar o círculo vicioso da irregularidade assegurando um conteúdo preventivo a tais politicas e programas." (SMOLKA, op. cit., p. 287).

${ }^{318}$ SMOLKA, op. cit., p. 277.
} 
assentamentos já consolidados. ${ }^{319}$

De maneira sintética e sem a pretensão de esgotar o tema, a oferta de moradias para a população de baixa renda pode ser ampliada por meio da implementação das mais variadas ações, dentre as quais se destacam: (i) a produção de novas unidades habitacionais voltadas ao atendimento da população de baixa renda; (ii) a reforma de imóveis abandonados, frequentemente encontrados em centros urbanos; (iii) o oferecimento de subsídio para a locação, chamada de "locação social”, para que o acesso não seja limitado a compra de imóvel por meio de financiamento; (iv) melhoria nas condições de financiamento para facilitar a aquisição de imóvel; (vi) o provimento de terrenos urbanizados a preços acessíveis; etc.

Não obstante a variedade de possibilidades aptas a contribuir para reverter a lógica do acesso ilegal ao espaço urbano, tais ações não são nenhuma novidade e vem sendo implementadas há algum tempo. ${ }^{320}$ Mesmo assim, a proliferação das irregularidades permanece sendo uma problemática corrente nas cidades brasileiras.

Ainda que outros fatores possam ser trazidos para justificar essa insuficiência da política habitacional para garantir a redução do acesso ilegal da população de baixa renda ao espaço urbano, ${ }^{321}$ é possível afirmar que a oferta não tem dado conta da existente demanda por moradia por parte da população de baixa renda. De um lado, porque os projetos empreendidos não tem ofertado moradia em número suficiente para suprir adequadamente a demanda e, de outro, porque continua havendo um mercado ilegal de promoção das moradias para população de baixa renda.

Tendo ambas as razões como norte, quais sejam a necessidade de ampliar a escala de produção de moradia de interesse social e reduzir ou eliminar o desenvolvimento do mercado informal, passamos a analisar de maneira breve iniciativas recentes que podem contribuir para o incremento da oferta, ora por envolver a produção em grande escala e ora por criar mecanismos que podem funcionar como atrativos para que o mercado informal passe a se desenvolver na legalidade.

\footnotetext{
319 FERNANDES, op. cit., 2010. No mesmo sentido, Betânia de Moraes ALFONSIN: "É importante reconhecer, no entanto, que o desenvolvimento de políticas de regularização fundiária, embora necessário, não é suficiente para dar conta daquele que é, de fato, o grande desafio urbano brasileiro: prevenir a produção irregular das cidades, por mecanismos legais e políticas públicas capazes de ofertar lotes e unidades habitacionais legais e compatíveis com a remuneração da população de baixa renda de nossas cidades." (ALFONSIN, op. cit., 2007, pp. 96-97).

${ }^{320}$ Conforme foi possível observar no capítulo II tão somente com a exposição de alguns programas federais.

321 Por exemplo, a ausência de priorização das políticas habitacionais, a escassez de recursos, a desorganização institucional para tratar a problemática etc.
} 
No âmbito da ampliação da oferta de unidades habitacionais de interesse social, importa destacar o modelo das Parcerias Público-Privadas, notadamente a concessão administrativa, ${ }^{322}$ já abordado anteriormente, enquanto alternativa para viabilizar investimentos em projetos de regularização fundiária urbana de interesse social.

Conforme destacado, além do ajuste contratual permitir um escopo ampliado, envolvendo obras e serviços (que podem abranger a manutenção das próprias unidades habitacionais e dos espaços comuns, a gestão do financiamento das unidades etc.), o fato da remuneração ser atrelada ao início da prestação dos serviços, podendo ser complementadas com receitas ancilares, bem como não ser o equilíbrio contratual fundado em planilha de preços dos materiais utilizados, ${ }^{323}$ mas sim da composição entre obrigações e riscos assumidos pelas partes, torna a etapa de obras célere, de um lado, porque o parceiro privado deseja receber a remuneração o quanto antes e, de outro, porque são reduzidas as hipóteses que ensejam um pleito de reequilíbrio contratual, fator que atrasa o andamento das obras.

Seguindo essa diretriz, o Projeto Jardins Mangueiral, desenvolvido pelo Governo do Distrito Federal, é a experiência pioneira de PPP no setor de habitação popular no Brasil. Por meio da concessão administrativa, o Distrito Federal contratou a construção de 8.000 (oito mil) unidades habitacionais de interesse social ${ }^{324}$ e a operação dos serviços de gestão do condomínio. A sustentabilidade econômica do empreendimento foi garantida por meio de contraprestação pública pecuniária, envolvendo o pagamento mensal dos serviços de gestão condominial, e não-pecuniária, abrangendo a cessão de direito de exploração econômica do empreendimento, com a venda das unidades habitacionais e gestão do financiamento de tais unidades, e a transferência da propriedade das áreas comerciais previamente estabelecidas. Destaca-se que o projeto foi iniciado em 2009 e já se encontra

\footnotetext{
${ }^{322}$ A concessão administrativa é modalidade adequada para projetos de habitação de interesse social, tendo em vista que esse tipo de serviços não pode ser inserido no conceito de serviços públicos em estrito senso, por não ser exclusivamente prestado pelo Estado e, ainda, por não ser aplicável à cobrança de tarifa.

${ }^{323}$ Como ocorre no modelo tradicional de execução indireta, notadamente por meio das modalidades de empreitada, em que a Lei federal $n^{0}$ 8.666/1993 estabelece um regime nada flexível em relação à alocação dos riscos e qualquer alteração no equilíbrio contratual decorrente dos fatos arrolados no art. 65, II, "d", da Lei federal $n^{\circ} 8.666 / 1993$ pode ensejar seu reequilíbrio, sendo que, nesse caso, o reequilíbrio é realizado com fundamento nas planilhas de preços dos materiais e seus quantitativos apresentada durante a licitação.

${ }^{324}$ Apesar de o projeto ser voltado para habitação de interesse social, importa destacar que em Brasília, estão incluídas, nesse conceito, famílias que recebem até 12 (doze) salários mínimos, enquanto que, a título de comparação, no Município de São Paulo, habitação de interesse social á para famílias que recebem até 5 (cinco) salários mínimos e habitação para moradia popular engloba faixa de renda de até 10 (dez) salários mínimos.
} 
quase finalizado. $^{325}$

No mesmo sentido, o Estado de São Paulo, por meio do Chamamento Público $n^{\circ}$ 4/2012 editado pelo Conselho Gestor do Programa Estadual de Parcerias Público-Privadas, deu início ao processo de chamamento $^{326}$ para o recebimento de estudos técnicos e modelagem de projetos de Parceria Público-Privada (PPP) de Habitação de Interesse Social a serem elaborados e pela iniciativa privada. A intenção do projeto é viabilizar a oferta de 50.000 (cinquenta mil) novas unidades habitacionais, tendo como prioridade: (i) habitação na região central da cidade de São Paulo; (ii) o provimento de moradias para a erradicação de áreas de risco; (iii) habitação para o desenvolvimento sustentável do Litoral Paulista. Não obstante o projeto ainda não ter sido contratado, já que se encontra em fase de elaboração dos estudos, é interessante notar a percepção de que esse formato de parceria por contribuir para a execução de tais empreendimentos em escalas elevadas.

Passando para o exame da possibilidade de reduzir o desenvolvimento do mercado ilegal de imóveis urbanos, atraindo esses investidores para a produção e comercialização de imóveis dentro da legalidade, salienta-se experiência empreendida em Porto Alegre por meio do chamado Urbanizador Social, previsto no Plano Diretor e regulamentado pela Lei Municipal $n^{\circ} 9.162 / 2003$ e pelo Decreto Municipal n ${ }^{0} 14.428 / 2004$.

Explicando a finalidade do mecanismo, esclarece Betânia Alfonsin:

A proposta encerrada no instrumento do "Urbanizador Social" é a de constituir um braço complementar da política municipal de habitação, fazendo que, para além de se garantir a segurança da posse e o direito à moradia dos que moram irregularmente, se ofereçam alternativas para que a população de baixa renda possa adquirir lotes no mercado imobiliário de forma regular e com preço acessível ao poder aquisitivo dessa população. Por meio do Urbanizador Social, portanto, o município pode estabelecer uma relação privilegiada tanto com os empreendedores privados regulares da cidade quanto com aqueles que hoje são loteadores clandestinos (nesse último caso, buscando atraílos para a regularidade), oferecendo-lhes, nos dois casos, incentivos para que os lotes produzidos tenham preços de fato acessíveis à

\footnotetext{
${ }^{325}$ Informações disponíveis em: <http://www.jardinsmangueiral.com.br/>. Acesso em: 30 dez. 2012.

${ }^{326}$ Por meio dos artigos 21 e 31, respectivamente das Leis federais $n^{\circ} 8.987 / 1995$ e $n^{\circ}$ 9.074/1995, além da legislação reforçar a possibilidade Poder Público receber estudos técnicos da iniciativa privada, agora envolvendo a modelagem de projetos de concessões e Parceria Público-Privada (PPP), também autorizou o eventual ressarcimento do autor dos estudos no caso de sua utilização no processo licitatório, bem como a participação do autor dos estudos no certame licitatório, antes vedado pelo art. $9^{\circ}$, inciso II da Lei federal $\mathrm{n}^{\circ}$ 8.666/1993. A partir de autorização geral, o tema foi regulado pela União, por meio do Decreto $n^{\circ}$ 5.977/2006, tendo alguns Estados, Municípios e o Distrito Federal estabelecido regras próprias. Sobre o tema, conferir: SILVA, Danilo Tavares da. Licitação na Lei ${ }^{0}$ 11.074/04. In: MARQUES NETO, Floriano de Azevedo e SCHIRATO, Vitor Rhein (coord.). Estudo Sobre a Lei das Parcerias Público-Privadas, Belo Horizonte: Editora Fórum, 2011, p. 75.
} 


\section{população de baixa renda. ${ }^{327}$ (grifo nosso)}

Assim, o instituto caracteriza-se por ser uma forma de parceria entre o Poder Público e a iniciativa privada, formalizada por meio de termo de compromisso, para o produção de habitação de interesse social.

De um lado, o Poder Público fica responsável por, dentre outros aspectos previstos no art. $5^{\circ}$ da Lei Municipal $n^{\circ}$ 9.162/2003: (i) priorizar a tramitação administrativa de empreendimentos promovidos pelo Urbanizador Social, de modo a agilizar o processo de aprovação do empreendimento; (ii) possibilitar a urbanização parcial e/ou progressiva do empreendimento; (iii) gravar a gleba como Área Especial de Interesse Social, podendo propor alteração do regime urbanístico; e (iv) transferir, em favor do Urbanizador Social, o potencial de construção das áreas que serão objeto de destinação pública, de acordo com o art. $6^{\circ}$ da Lei Municipal $n^{\circ} 9.162 / 2003$.

Como encargos do Urbanizador Social, o art. $8^{\circ}$ da Lei Municipal n ${ }^{\circ}$ 9.162/2003 estabelece o seguinte: (i) apresentação de planilha do custo do empreendimento, bem como do perfil socioeconômico dos adquirentes; (ii) produção de lotes ou unidades habitacionais a preço compatível com a urbanização social; (iii) oferecimento de contrapartida ao Município, que pode realizá-la por meio do repasse ao Poder Público de um percentual dos lotes produzidos, da comercialização direta de parte dos lotes com adquirentes indicados pelo Poder Público, da doação de terreno a ser destinado a outras finalidades públicas ou a construção de equipamentos públicos, bem como de conversão do valor da contrapartida em abatimento no preço final dos lotes.

Sintetizando o apresentado, buscou-se no presente tópico indicar que, apesar de existirem uma série de mecanismos que podem atuar no sentido de prevenir o acesso irregular do solo urbano pela população de baixa renda, diante da constatação de que apenas a regularização fundiária urbana de interesse social não é capaz de reverter a lógica do acesso ilegal por ser essencialmente curativa, há necessidade do Poder Público atuar em duas vertentes que podem ser combinadas entre si: (i) aumentando a escala na produção de habitação de interesse social; e (ii) buscando trazer para a legalidade a produção de lotes que se desenvolvem na ilegalidade, por meio de incentivos e não apenas se utilizando do tradicional método de repressão.

\footnotetext{
${ }^{327}$ ALFONSIN, Betânia. Depois do Estatuto da Cidade: ordem jurídica e política urbana em disputa. Porto Alegre e o Urbanizador Social. In: Revista Brasileira de Estudos Urbanos e Regionais, v. 7, n. 2, 2005, p. 53.
} 


\subsubsection{Procedimentalização para a definição das áreas beneficiárias de processos de regularização fundiária urbana de interesse social}

Além da constatação de que os processos de regularização fundiária urbana de interesse social não são efetivos se deixarem de ser combinados com políticas preventivas, a realização de tais processos sofre com outros problemas externos que acabam por afetar a sua efetividade. Trata-se da descontinuidade de investimentos públicos para dar conta do processo como um todo, bem como da realização de práticas clientelistas em períodos eleitorais, ambos decorrentes da falta de planejamento e de responsabilização dos governos com políticas empreendidas por governos anteriores.

A tentativa de vincular os processos de regularização fundiária urbana de interesse social ao planejamento urbano, expresso por meio do Plano Diretor ou lei correspondente e, ainda, pelo próprio Sistema Nacional de Habitação de Interesse Social que estipula a necessidade de desenvolvimento do Plano de Habitação para receber recursos, acaba sendo uma forma de mitigar ambas as consequências.

Não há na ordem jurídica, no entanto, a estipulação clara da necessidade de procedimentalização da tomada de decisão acerca da escolha das áreas que serão efetivamente beneficiadas na esfera da própria Administração Pública, tendo em vista que os planos desenvolvidos no âmbito do planejamento urbano acabam indicando um rol de possíveis beneficiárias, deixando a decisão a ser tomada em concreto pela Administração.

Não obstante se considere correta a orientação de deixar a cargo da Administração Pública decidir em concreto as priorizações que serão feitas no âmbito da política de regularização fundiária urbana de interesse social, essa decisão também deve respeitar um procedimento que leve em conta: (i) a existência ou não de situação de risco, priorizando o tratamento das situações que apresentam risco à vida da população beneficiária; (ii) as demandas entendidas como prioritárias pelos beneficiários; (iii) o grau de consolidação da área ocupada; (iv) o grau de dificuldade envolvido no processo de legalização do exercício da posse; (v) o nível de organização social da população beneficiada; (vi) a existência de demarcação do local como zona especial de interesse social; (vii) os custos envolvidos no processo; (viii) a possibilidade de combinar o processo de regularização fundiária urbana de interesse social com outros projetos que venham a contribuir para a sua financiabilidade; etc. 
Em suma, garantir que a decisão seja tomada de modo a considerar o maior número de variáveis possíveis, bem como de interesses envolvidos no processo de regularização fundiária urbana de interesse social.

O tema da procedimentalização das tomadas de decisão da Administração Pública está diretamente relacionado ao tradicional instituto do regime de direito público: a discricionariedade administrativa. Apesar de tradicional, sua concepção original vem sofrendo consideráveis alterações, notadamente no tocante à motivação que dá embasamento para a decisão do administrador, bem como naquilo que se refere à abrangência do controle a que tais decisões estão sujeitas.

Mencionadas alterações, por evidente, impactam na conduta a ser desempenha pela Administração Pública no processo de tomada de decisão, não apenas no sentido de explicitar com detalhamento as razões que levaram à adoção de determinada escolha, mas principalmente na busca pela legitimação das opções adotadas. ${ }^{328}$ Esse movimento, em verdade, relaciona-se intrinsecamente com a alteração da noção de supremacia do interesse público como princípio legitimador do exercício de prerrogativas exorbitantes pela Administração Pública em relação aos administrados, de modo absoluto.

Apresentando brevemente a questão, o princípio da supremacia do interesse público é adotado para justificar a existência de prerrogativas públicas e unilaterais necessárias para o exercício da atividade administrativa, bem como para garantir que o aparato estatal seja utilizado para atingir uma finalidade pública e não aos interesses privados de grupos específicos. Nesse sentido, o interesse público encontrar-se-ia em patamar de superioridade aos interesses privados, suficiente para legitimar a decisão da administração pública em um sentido e não em outro.

Percebe-se como elemento central dessa teorização a existência de um antagonismo entre "interesses privados" e interesse público, já que, se tal antagonismo não existisse, não haveria razão para colocar o interesse público em patamar de superioridade.

\footnotetext{
${ }^{328}$ Situando tal questão no âmbito da doutrina administrativista, Odete Medauar esclarece: "Se num primeiro momento da atenção doutrinária o processo administrativo significava meio de observância dos requisitos de validade do ato administrativo e garantia de respeito aos direitos dos indivíduos, seus objetivos foram se ampliando à medida em que se alteravam as funções do Estado e da Administração, as relações entre Estado e sociedade e as próprias concepções do Direito Administrativo. Extrapolou-se o perfil do processo administrativo ligado somente à dimensão do ato administrativo em si, para chegar até a legitimação do poder. Saiu-se da perspectiva interna para chegar a perspectivas sociais e políticas da processualidade administrativa." (MEDAUAR, op. cit., 2008, p. 65).
} 
Considerando, pois, o antagonismo como cerne do raciocínio, um exemplo comum da necessidade desse tipo de prerrogativa para o exercício da atividade administrativa e o atingimento do interesse público seria o instituto da desapropriação ${ }^{329}$. Nesse exemplo, o antagonismo de interesses coloca-se da seguinte forma: necessidade de utilizar determinada propriedade para uma finalidade pública versus o interesse do proprietário em manter-se em sua propriedade. Percebe-se que o raciocínio só faz sentido se considerarmos os interesses envolvidos na desapropriação de maneira tão restrita e isolada dos demais interesses da sociedade que só se enxerga o antagonismo no interesse privado do particular dono do imóvel desapropriado, afastando toda a complexidade da sociedade e os demais interesses privados envolvidos que não são antagônicos e se beneficiam do exercício da supremacia do interesse público. ${ }^{330}$

Sendo assim, outra forma de abordar a questão colocada seria no sentido de reconhecer que a Administração Pública, ao promover uma desapropriação, pondera os interesses privados existentes na sociedade em face da situação concreta que enseja sua atuação e acaba por escolher os interesses privados que irá privilegiar por meio da aplicação de prerrogativas públicas. Segundo Marques Neto:

Num Estado republicizado, a legitimação da atuação do poder político depende, permanentemente, da capacidade de demonstrar, discursivamente, o porquê da ação desigual no sentido de privilegiar um ou outro interesse público em confronto. Mais ainda, tal legitimidade advém igualmente da capacidade de se fazer presente e atuante como garante dos interesses públicos difusos. ${ }^{331}$

Essa abordagem diversa ocorre, não em função da redução da importância do interesse público, mas como decorrência da compreensão de que se trata de expressão que apresenta um conteúdo extremamente aberto, em que a mera indicação de superioridade

\footnotetext{
${ }^{329}$ Nesse sentido, Celso Antônio Bandeira de Mello expõe: "Afinal, o princípio em causa (supremacia do interesse público) é um pressuposto do convívio social. [...]. Para não deixar sem referência constitucional algumas aplicações concretas especificamente dispostas na Lei maior e pertinentes ao Direito Administrativo, basta referir os institutos da desapropriação e da requisição (art. $5^{\circ}$, XXIV e XXV), nos quais é evidente a supremacia do interesse público sobre o privado." (Curso de Direito Administrativo. 18. ed. São Paulo: Malheiros, 2004, p.87)

${ }^{330}$ Ao mesmo tempo que há o interesse privado do proprietário, cuja propriedade será desapropriada, como antagônico, há uma série de outros interesses privados envolvidos que seriam beneficiados da desapropriação, por exemplo, no caso da desapropriação beneficiar população de baixa renda no âmbito de determinado projeto de regularização fundiária urbana de interesse social. Isso significa dizer que não é o antagonismo entre interesses públicos e privados que justifica o exercício das prerrogativas públicas decorrentes do princípio da supremacia do interesse público, tendo em vista que o interesse público em questão sempre acaba por beneficiar, mesmo que indiretamente, interesses privados.

331 A Republicização do Estado e os Interesses Públicos. Tese de doutorado. Faculdade de Direito. Universidade de São Paulo, 1999, p. 254.
} 
não dá conta da complexidade das relações travadas entre Administração Pública e administrados no contexto contemporâneo. ${ }^{332}$

Nessa esteira, a formação da vontade pública para eleição das prioridades sofre um deslocamento da esfera unilateral da Administração Pública para perquirir a consensualidade na tomada de decisões, que abrange além da função de arbitramento, " $a$ função de composição desses interesses, por meio da qual a Administração busca harmonizar os interesses em conflito seja entre os particulares, seja em relação ao próprio Poder Público." 333

Para tanto, mesmo existindo margem de discricionariedade, cabe à Administração Pública estabelecer um procedimento prévio que garanta, no caso concreto, a identificação dos interesses conflitantes, da melhor forma de arbitrá-los e da possibilidade de harmonizálos. Esse imperativo bem espelha a ideia de que "a Administração Pública, hoje, é menos uma adjudicadora de direitos previstos em lei e muito mais um árbitro de interesses públicos legítimos colidentes em cada situação concreta." 334

Nota-se que a própria Lei federal $n^{0} 11.977 / 2009$, que regula o Programa Minha Casa, Minha Vida, segue a lógica aqui exposta quando condiciona a efetivação da demarcação urbanística em imóvel privado, que dá início ao processo de regularização fundiária, à concordância do proprietário. Ambos são considerados assim como interesses públicos legítimos.

No caso da regularização fundiária urbana de interesse social, o procedimento, que em grande medida encontra sua diretriz no próprio planejamento urbano, buscará justificativa para a escolha entre tal e qual área, tal e qual irregularidade e tal e qual mecanismo, tendo em vista a enorme gama de institutos que, inclusive, podem ser combinados para o atingimento das finalidades coletivas, conforme delineado nos Capítulos anteriores.

\footnotetext{
332 “O princípio da supremacia do interesse público, parece-nos, deve ser aprofundado de modo a adquirir a feição da prevalência dos interesses públicos e desdobrando-se em três subprincípios balizadores da função administrativa: (i) a interdição do atendimento de interesses particularísticos (v.g., aqueles desprovidos de amplitude coletiva, transindividual); (ii) a obrigatoriedade de ponderação de todos os interesses públicos enredados no caso específico; e (iii) a imprescindibilidade de explicitação das razões de atendimento de um interesse público em detrimento dos demais”. (MARQUES NETO, Floriano de Azevedo. Regulação Estatal e Interesses Públicos, São Paulo: Malheiros, 2002, p. 165.)

${ }^{333}$ PALMA, Juliana Bonacorsi de. Atuação Administrativa Consensual: Estudo dos acordos substitutivos no processo administrativo sancionador. Dissertação de Mestrado. Faculdade de Direito. Universidade de São Paulo, 2010, p. 151-152.

334 MARQUES NETO, Floriano de Azevedo. Discricionariedade Administrativa e Controle Judicial da Administração. In: Boletim de Direito Administrativo, junho/2002, p.462.
} 
Além de o procedimento contribuir para a Administração Pública melhor adjudicar interesses, tem um papel central como mecanismo de legitimação da opção adotada, seja por congregar aspectos que contribuem para a fundamentação da decisão proveniente do exercício da discricionariedade, seja por garantir maior permeabilidade às demandas, principalmente da população de baixa renda, que, no âmbito da política de regularização fundiária urbana de interesse social, é a beneficiária direta. ${ }^{335}$

Em relação ao tema, há ainda outro aspecto a ser salientado e que, além de também decorrer dessa nova forma de entender a atuação da Administração Pública, pode contribuir para a fundamentação da decisão adotada. Trata-se da necessidade da atuação da administração deixar de ser conduzida apenas por critérios de legalidade e ilegalidade, e passar a ser governada por juízos de ponderação que envolvam os demais princípios constitucionais dentre os quais se destacam, por óbvio, os direitos fundamentais e sociais.

Esse fenômeno, caracterizado pelo alargamento do conceito de lei, é identificado como a chamada submissão da Administração à jurisdicidade, sendo que a atividade administrativa passa a encontrar fundamento: (i) na lei, quando constitucional; (ii) diretamente na Constituição; ou (iii) no direito, ainda que contrário à lei, por meio de uma ponderação com outros princípios constitucionais que não apenas o da legalidade. Sobreleva-se, pois, a importância dos princípios e regras constitucionais na densificação do ambiente decisório do administrador. Nesse sentido, “o agir administrativo pode encontrar espeque e limite diretamente em regras ou princípios constitucionais, dos quais decorrerão, sem necessidade de mediação do legislador, ações ou omissões da Administração." 336

Tais juízos de ponderação são, inclusive, previstos como diretrizes gerais da política urbana no art. $2^{\circ}$ do Estatuto da Cidade e caracterizam-se, portanto, como premissas para a adoção dos institutos voltados à regularização fundiária urbana de interesse social.

O exame empreendido, portanto, permite concluir que a procedimentalização da tomada de decisão delegada pela legislação à Administração Pública é mecanismo apto a

\footnotetext{
335 Ressaltando a relevância do envolvimento da sociedade, tomando como base o processo mais amplo de planejamento urbano no município de São Paulo refletido na implantação da legislação sobre zoneamento, Sarah Feldman esclarece que tal processo é marcado "pela utilização de estratégias que negam qualquer debate com a sociedade e qualquer preocupação em legitimar o instrumento para além do círculo de interlocutores que se mobilizavam em torno de interesses particulares e localizados." (FELDMAN, op. cit., p.282).

${ }^{336}$ BINENBOJM, Gustavo. Uma Teoria do Direito Administrativo. Rio de Janeiro: Renovar, 2006, p. 70.
} 
garantir que a atuação administrativa seja realizada a partir da ponderação: (i) de interesses privados legítimos, especialmente da população de baixa renda; (ii) de mecanismos aptos a serem adotados e (iii) de formas de viabilização de investimentos. Desse modo, a Administração atua no sentido de legitimar as prioridades eleitas.

Por meio de tal mecanismo, não há dúvida de que o risco à efetividade decorrente do fator externo relacionado à descontinuidade de investimentos públicos em projetos de regularização fundiária urbana de interesse social, bem como à realização de práticas clientelistas em períodos eleitorais seria naturalmente mitigado, diante da dificuldade de uma decisão bem embasada, ponderada e legitimada pelo processo, podendo ser revertida sem custo político.

\subsection{Síntese conclusiva do capítulo}

O capítulo apresentou uma análise crítica do instituto da regularização fundiária urbana de interesse social de modo a identificar aspectos problemáticos, internos ou externos aos processos de regularização, que acabam por afetar em alguma medida sua efetividade, bem como as formas passíveis de mitigar tais ineficácias.

De modo sintético, algumas conclusões podem ser expressas. Primeiramente, foram destacados três aspectos que afetam internamente a efetividade da regularização fundiária urbana de interesse social: (i) a amplitude da concepção do instituto; (ii) a complexidade e lentidão decorrentes do desencadeamento do processo; e, ainda, (iii) os elevados custos nele envolvidos.

Acerca de cada uma das problemáticas internas, restou demonstrado que: (i) a legislação brasileira contribui no sentido de mitigar a ineficácia do instituto quando: (a) adota uma concepção ampla, que compreende a dimensão da regularização dominial e da urbanização, (b) estabelece regras claras no âmbito do registro dos títulos originados em processos de regularização fundiária, bem como (c) cria um procedimento inteiramente administrativo, sem a participação do judiciário; e (ii) os custos elevados para a urbanização de assentamentos irregulares reforçam a necessidade: (a) desse tipo de medida ser adotada pelo Poder Público em sede de exceção; e (b) do Poder Público buscar viabilizar investimentos por meio da utilização de outros modelos de ajuste, tratados no quarto capítulo. 
Como problemáticas externas ao instituto, foram apresentadas as seguintes constatações: (i) a regularização fundiária urbana de interesse social acaba por gerar mais irregularidade; e (ii) há descontinuidade da ações voltadas à regularização, bem como sua utilização para fins eleitoreiros.

No que se refere à ampliação da irregularidade, constatou-se a necessidade de reconhecer o caráter curativo inerente à regularização fundiária urbana de interesse social e, portanto, combiná-la com políticas preventivas. Entretanto, o estabelecimento de políticas preventivas deve ter como norte: (i) o aumento da escala na produção de habitação de interesse social; e (ii) a busca por resgatar o produtor de lotes ilegais para a produção dentro da legalidade, por meio de incentivos e não apenas fazendo uso do tradicional método de repressão.

Acerca da descontinuidade dos processos de regularização fundiária ou, ainda, seu uso para fins eleitoreiros, apresentou-se como elemento central para mitigar esse risco de desvirtuamento do processo de regularização, a criação de um procedimento na esfera administrativa que permita o exercício da discricionariedade a partir da ponderação: (i) de interesses privados legítimos, especialmente da população de baixa renda; (ii) de mecanismos aptos a serem adotados em casa caso concreto; e (iii) das melhores formas para viabilização de investimentos. Sendo assim, a melhor forma de combater o desvirtuamento, seria por meio da institucionalização de um procedimento que contribua para uma decisão fundamentada e legitimada. 


\section{CONSIDERAÇÕES FINAIS}

Tendo percorrido o instituto da regularização fundiária urbana de interesse social em sua plenitude, desde de os seus fundamentos até as suas deficiências, evidenciou-se o dilema central que envolve a aplicação do instituto. De um lado o reconhecimento de que as ocupações irregulares do espaço urbano geram direitos à população de baixa renda que demandam uma atuação interventiva do Poder Público para serem concretizados. De outro, a sensação de que apenas a regularização fundiária não tem o condão de garanti-los, já que apresenta sérias problemáticas inerentes ou externas ao instituto que não foram completamente equalizadas na esfera institucional.

Situando o tema em concepção ampla, foi possível concluir que a regularização fundiária urbana de interesse social, fundada no princípio da função social da propriedade urbana e no direito à moradia, compreende ações voltadas à população predominantemente de baixa renda, que englobam a legalização da posse dos ocupantes, a flexibilização das normas referentes ao parcelamento, uso e ocupação, para garantir a melhoria estrutural das ocupações, e a urbanização do solo e das edificações ocupados irregularmente em área urbana, incluindo Área de Preservação Permanente nos casos de área urbana consolidada.

Percebe-se que a conceituação adotada acaba por deixar evidente a complexidade das questões envolvidas nos processos de regularização fundiária de interesse social.

A análise das origens das irregularidades, ainda que apresentadas de modo sucinto, possibilitou constatar que a ausência de um mercado formal para atender à população de baixa renda tem fundamento: (i) na incapacidade das políticas de provimento de habitação popular darem conta de ofertar o montante de unidades habitacionais necessário para sanar a demanda por moradia popular; (ii) nas opções de alguns governos no sentido de conduzir o desenvolvimento do espaço urbano em benefício de elites; (iii) na desarticulação da execução das políticas formuladas; (iv) na ausência de mecanismos voltados para a regularização fundiária urbana de interesse social, sendo recente a incorporação dessa diretriz na política habitacional; e (v) na pouca articulação entre regularização fundiária urbana de interesse social e provimento de moradia popular. 
No âmbito das competências, a Constituição Federal cuidou de responsabilizar a todos os entes, em alguma medida, pela formulação de normas e pela execução de políticas que abrangem a regularização fundiária urbana de interesse social, e, ao mesmo tempo, conferir papel de destaque aos Municípios. No entanto, a dependência do Município em relação aos recursos federais ou a sua reduzida capacidade institucional, acabam por encurtar a margem de autonomia dos Municípios na prática, passando a ter a União papel central, não apenas, mas também no que toca a regularização fundiária de interesse social.

O exame dos instrumentos, incluindo aqueles voltados para a legalização do exercício da posse, a alteração de normas urbanísticas voltadas ao parcelamento, uso e ocupação do solo e das edificações, bem como da urbanização, admite concluir que a legislação oferece um aparato completo de mecanismos aptos a se adequarem às mais variadas situações concretas de irregularidade. Nada impede, ainda, que tais instrumentos sejam combinados entre si para atingir a finalidade da regularização fundiária.

A abordagem do instituto para além dos moldes tradicionalmente encontrados na doutrina, permitiu trazer para a análise, além dos institutos utilizados para a legalização do exercício da posse, flexibilização de normas urbanísticas e urbanização, alguns instrumentos capazes de viabilizar a realização de investimentos em processos de regularização fundiária urbana de interesse social, tendo em vista que tais projetos, isoladamente, têm pouca ou nenhuma capacidade de serem autossustentáveis do ponto de vista econômico-financeiro e, ainda, demandam elevados investimentos. Nesse sentido, há uma enorme quantidade de possibilidades de arranjos contratuais que garantem fontes e formas de custeio diferenciadas a depender da situação concreta e da necessidade do Município.

Por fim, a análise crítica da regularização fundiária urbana de interesse social permitiu afirmar que suas ineficiências decorrem de fatores internos, que, de certo modo, vem sendo mitigados pela legislação, e externos, que acabam por demandar a combinação da política de regularização com políticas de caráter preventivo no sentido de evitar que o único meio de acesso da população de baixa renda ao espaço urbano seja pela via da ilegalidade, e a procedimentalização da tomada de decisão no âmbito da discricionariedade que envolve a escolha das áreas beneficiadas como forma de evitar que tais procedimentos sejam utilizados de maneira descontinuada e clientelista. 


\section{REFERÊNCIAS}

ALDRICH, Brian C.; SANDHU, Ranvinder S. Housing the Urban Poor: Policy and Practice en Developing Coutries. London e New Jersey: Zed Books, 1995.

ALEXY, Robert. Teoria dos direitos fundamentais. São Paulo: Malheiros, 2008.

ALFONSIN, Betânia. Depois do Estatuto da Cidade: ordem jurídica e política urbana em disputa. Porto Alegre e o Urbanizador Social. In Revista Brasileira de Estudos Urbanos e Regionais, v. 7, n. 2, 2005, pp. 47-59.

. Direito à moradia: instrumentos e experiências de regularização fundiária nas cidades brasileiras. IPPUR/FASE - Observatório de Políticas Urbanas, v. 01, 1997.

. (et alli). Regularização da Terra e Moradia: o que é e como implementar. Brasília: CAIXA/PÓLIS/FASE/ACESSO, ago./out., 2002.

. Operações urbanas consorciadas como instrumento de captação de mais-valias urbanas: um imperativo da nova ordem jurídico-brasileira. In ALFONSIN, Betânia; FERNANDES, Edésio (coord.). Direito Urbanístico Estudos Brasileiros e Internacionais, Belo Horizonte: Del Rey e Boston: Lincoln Institute os Land Policy, 2006, pp. 287-300.

- O significado do Estatuto da Cidade para os processos de regularização fundiária no Brasil. In: Regularização Fundiária Plena referencias conceituais. Brasília: Ministério das Cidades, 2007, pp. 69-98.

ALFONSIN, Jacques Távora. Reforma urbana. "invasões" de áreas urbanas favelas. In: Estudos Jurídicos, São Leopoldo, v. 19, n. 46, maio/ago, 1986.

ALMEIDA, Fernando Dias Menezes de. Contrato Administrativo. São Paulo: Quartier Latin, 2012.

. Dos instrumentos em geral. Do direito de superfície. In: ALMEIDA, Fernando Dias Menezes de; MEDAUAR, Odete (coord.). Estatuto da Cidade - Lei $n^{\circ}$ 10.527, de 10.07.2001: Comentários. 2. ed. São Paulo: Revista dos Tribunais Ltda., 2004, pp. 163-186.

. Dos instrumentos da política urbana. Do parcelamento, edificação ou utilização compulsórios. Do IPTU progressivo no tempo. Da desapropriação com pagamento em títulos. In: ALMEIDA, Fernando Dias Menezes de; e MEDAUAR, Odete (coord.). Estatuto da Cidade - Lei $n^{o}$ 10.527, de 10.07.2001: Comentários. 2. ed. São Paulo: Revista dos Tribunais Ltda., 2004, pp. 41-119.

; MEDAUAR, Odete (coord.). Estatuto da Cidade - Lei $n^{o}$ 10.527, de 10.07.2001: Comentários. 2. ed. São Paulo: Revista dos Tribunais Ltda., 2004. 
ARAÚJO, Edmir Neto de. Do negócio jurídico administrativo. São Paulo: Revista dos Tribunais, 1992.

AZEVEDO, Sérgio de; GUIA, Virgínia Rennó dos Mares. Os Dilemas da Gestão Metropolitana no Brasil. In: RIBEIRO, Luiz Cesar de Queiroz (org.). Metrópoles: entre a coesão e a fragmentação, a cooperação e o conflito. Fundação Perseu Abramo/FASE/Observatório das Metrópolis, 2004, pp. 97-101.

BALBIM, Renato. Avanços recentes no quadro normativo federal da regularização fundiária. In: Planejamento e Políticas Públicas, Brasília: IPEA, n. 34, jan/jun, 2010, pp. 289-320.

BASTOS, Celso Ribeiro; MARTINS, Ives Gandra da Silva. Comentários à Constituição do Brasil, São Paulo: Saraiva, $7^{\circ}$ volume, 1990.

BASTOS, Paulo. Urbanização de favelas. In: Estudos Avançados, São Paulo, v. 17, n. 47. jan./abr, 2003, pp. 212-221.

BIENENSTEIN, Regina. Redesenho Urbanístico e Participação Social em Processos de Regularização Fundiária. Tese de doutorado. Faculdade de Arquitetura e Urbanismo. Universidade de São Paulo, São Paulo, 2001.

BINENBOJM, Gustavo. Uma Teoria do Direito Administrativo. Direitos Fundamentais, Democracia e Constitucionalização. Rio de Janeiro: Renovar, 2006.

BONDUKI, Nabil. Origens da Habitação Social no Brasil. In: Análise Social, Lisboa, vol. XXIX, 1994, pp. 711-732.

BUCCI, Maria Paula Dallari. Políticas Públicas: reflexões sobre o conceito jurídico. São Paulo: Saraiva, 2006.

- Políticas Públicas e Direito Administrativo. In: Revista de Informação Legislativa, Brasília, a. 34, n. 133, jan./mar, 1997, pp. 89-98.

Cooperativas de habitação no direito brasileiro. São Paulo: Saraiva, 2003.

CALDAS, Roberto Correia da Silva Gomes. O fenômeno da legalização das favelas e sua transmutação em concessões públicas. In: Interesse Público, Porto Alegre, v.8. n. 37, 2006, pp. 321-334.

CALDERÓN, Julio. El misterio del crédito. In: SMOLKA, Martin O. e MULLAHY, Laura (editores). Perspectivas urbanas, Temas críticos en políticas de suelo en América Latina, Cambridge: Lincoln Institute of Land Police, 2007, pp. 116-121.

Mercado de tierras urbanas, propriedade y probreza. Lima: Sinco Editores; e Cambridge: Lincon Instituto of Land Policy, 2006. 
CARDOSO, Ana Cláudia Duarte. Assentamentos informais e a pobreza urbana. Belém em foco. In: VALENÇA, Márcio Moraes (org.), Cidade (i)legal, Rio de Janeiro: Mauad X, 2008, pp. 163-218.

CARDOSO, Patrícia de Menezes. Democratização do acesso à propriedade pública no Brasil: função social e regularização fundiária. Dissertação de mestrado. Pontifícia Universidade Católica de São Paulo, São Paulo, 2010.

CARNEIRO, Ruy de Jesus Marçal. A Constituição Federal de 1988 e a politica urbana. In: FADAP-Revista Jurídica, Tupã, n.1, 1998, pp. 1-52.

CARVALHO FILHO, José dos Santos. Propriedade, política e Constituição. In: Revista da EMERJ, Rio de Janeiro, v.6, n. 23, 2003.

CENECORTA, Afonso Iracheta; SMOLKA, Martim O. O Paradoxo da Regularização Fundiária: acesso à terra servida e pobreza urbana no México. In: Cadernos IPPUR, Rio de Janeiro, a. XIV, no 1, 2000, pp 87-117.

CORDEIRO, Débora Ortegosa. Politicas de intervenção em favelas e as transformações nos programas, procedimentos e práticas: a experiência de atuação do município de Embu. Dissertação de mestrado. Faculdade de Arquitetura e Urbanismo. Universidade De São Paulo, São Paulo, 2009.

COSTA, Fernanda Carolina Vieira da; BUENO, Laura Machado de Mello. Ocupação e Favelas. In: ALFONSIN, Betânia (et alli). Regularização da Terra e Moradia: o que é e como implementar. Brasília: CAIXA/POLIS/FASE/ACESSO, ago./out., 2002, pp. 70-81.

COSTA, Maria Alice Nunes. Sinergia e capital social na construção de políticas sociais: a favela da mangueira no Rio de Janeiro. In: Revista de Sociologia e Política, Curitiba, n. 21, nov., 2003, pp. 147-163.

COSTA, Regina Helena. O Estatuto da Cidade e os novos instrumentos da política urbana. In: Revista de Direito Imobiliário, São Paulo, v.24, n.51, jul./dez., 2001.

CUSTODIO, Helita Barreira. Desafetação e concessão de bens de uso comum do povo invadidos e transformados em favelas incompatibilidades juridico-urbanistico-ambientais. In: Revista de Direito Civil, Imobiliário, Agrário e Empresarial, São Paulo, v.14, n.53, 1990.

DALLARI, Adilson de Abreu. Concessões urbanísticas. In: Fórum de Direito Urbano e Ambiental - FDUA, Belo Horizonte, a. 5, n. 27, maio/jun. 2006. Disponível em $<$ http://www.bidforum.com.br/bid/PDI0006.aspx?pdiCntd=35920>. Acesso em: 22 set. 2012.

. Desapropriações para fins urbanísticos. Rio de Janeiro: Forense, 1981.

; FERRAZ, Sérgio (coord.). Estatuto da cidade: Comentários à Lei Federal $n^{o}$ 10.257/2001. 2. ed. São Paulo: Malheiros, 2003. 
Instrumentos da Política Urbana. In DALLARI, Adilson Abreu; FERRAZ, Sérgio. Estatuto da Cidade, Comentários à Lei $n^{\circ}$ 10.527/2001. São Paulo: Malheiros, 2002, pp. 71-86.

; MARQUES NETO, Floriano de Azevedo; SUNDFELD, Carlos Ari. Parcerias público-privadas. São Paulo: Malheiros, 2005.

; FIGUEIREDO, Lucia Valle. Temas de Direito Urbanístico. São Paulo: Revista dos Tribunais, 1987.

DALLARI, Dalmo. Usucapião Coletivo. In: Revista Informativa Legislativa, Brasília, a. 29 n. 115, jul./set., 1992, pp. 373-380.

DAMASIO, Cláusio P.; SMOLKA, Martin O. El Urbanizador Social: un experimento en políticas del suelo en Porto Alegre. In: SMOLKA, Martin O. e MULLAHY, Laura (editores). Perspectivas urbanas, Temas críticos en políticas de suelo en América Latina.. Cambridge: Lincoln Institute of Land Police, 2007, pp. 135-142.

DI PIETRO, Maria Sylvia Zanella. Concessão de Uso Especial para Fins de Moradia (Medida Provisória $\mathrm{n}^{\mathrm{o}}$ 2.220, de 4.9.2001). In: DALARRI, Adilson de Abreu; FERRAZ, Sérgio (coord.). Estatuto da cidade: Comentários à Lei Federal $n^{\circ} 10.257 / 2001$. 2. ed. São Paulo: Malheiros, 2003, pp. 149-170.

. Direito Administrativo. 18. ed. São Paulo: Atlas, 2005.

- Parcerias na Administração Pública. Concessão, Permissão, Franquia,

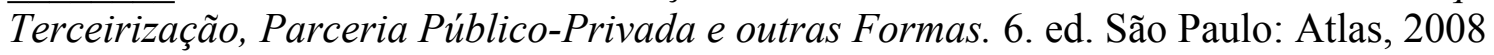

Uso privativo de bem público por particular. São Paulo: Revista dos tribunais, 1983.

D'OTTAVIANO, Maria Camila Loffredo e SILVA, Sérgio Luis Quaglia. Regularização Fundiária no Brasil: velhas e novas questões. In: Planejamento e Políticas Públicas, Brasília, nº 34, jan/jun, 2010, pp. 201-229.

DOWELL, Maria Cristina Mac. Financiamento urbano no Brasil: um olhar sobre as finanças municipais. In: CESARE, Claudia M. de; CUNHA, Eglaísa Micheline Pontes. Programa Nacional de Capacitação das Cidades - Financiamento das cidades: instrumentos fiscais e de politica urbana. Brasil: Ministério das Cidades, 2007, p. 36

EISENMANN, Charles. O direito administrativo e o princípio da legalidade. In: Revista de Direito Administrativo, Rio de Janeiro, v. 56, abr./jun., 1959.

FARIA, Carlos Aurélio Pimenta de; ROCHA, Carlos Alberto de Vasconcelos. Federalismo, relações intergovernamentais e gestão metropolitana no Brasil. In: CASTRO, Erika; WOJCIECHOWSKI, Maciej John (org.). Coleção Limites das Cidade - Inclusão Colaboração e governança urbana: Perspectivas brasileiras. Belo Horizonte: PUC Minas, 
2010, pp. 101-119.

FELDMAN, Sarah. Planejamento e zoneamento - São Paulo 1947-1972. São Paulo: FAPESP; Edusp, 2005.

FELIPE, Arley César. Apontamentos sobre a divisão da competência urbanística no federalismo brasileiro atual. In: Revista do Curso de Direito da Universidade de Uberlândia, Uberlândia, v. 27, n. 1, jun., 1998.

FERNANDES, Edésio. Desafios da regularização fundiária de assentamentos informais consolidados em áreas urbanas. In: Biblioteca Digital Fórum de Direito Urbano e Ambiental - FDUA, Belo Horizonte, ano 9, n. 49, jan/fev. 2010. Disponível em: $<$ http://www.editoraforum.com.br/bid/bidConteudoShow.aspx?idConteudo=65211 $>$.

Acesso em: 21 fev. 2011.

Direito Urbanístico: entre a "cidade legal"e a "cidade ilegal". In: FERNANDES, Edésio (org.). Direito Urbanístico. Belo Horizonte: Del Rey, 1988.

. Introdução. In: ALFONSIN, Betânia (et alli). Regularização da Terra e Moradia: $o$ que é e como implementar. Brasília: CAIXA/PÓLIS/FASE/ACESSO, ago./out., 2002, p.12-13.

. La influencia de El misterio del capilal de Hernando de Soto. In: SMOLKA, Martin O. e MULLAHY, Laura (editores). Perspectivas urbanas, Temas críticos en políticas de suelo en América Latina. Cambridge: Lincoln Institute of Land Police, 2007, pp. 108-115.

; PEREIRA, Helena Dolabela. Legalização das favelas: Qual é o problema de Belo Horizonte? In: Planejamento e Políticas Públicas, Brasília, n. 34, jan/jun, 2010, pp. 171-199.

Política Nacional de Regularização Fundiária: contexto, propostas e limites. In:

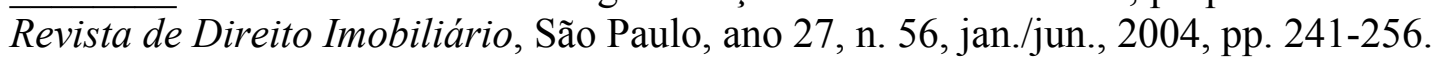

- Princípios, Bases e Desafios de uma Política Nacional de Apoio à Regularização Fundiária Sustentável. In: AFONSIN, Betânia; FERNANDES, Edésio. Direito à Moradia e Segurança da Posse no Estatuto da Cidade. Belo Horizonte: Editora Fórum, 2004, pp. 309-364.

FERRAZ, Sérgio. Usucapião Especial. In: DALLARI, Adilson de Abreu; FERRAZ, Sérgio (coord.). Estatuto da Cidade: Comentários à Lei Federal $n^{o}$ 10.257/2001. São Paulo: Malheiros, 2003, p. 137-148.

FIX, Mariana. Parceiros da exclusão: duas histórias da construção de uma nova cidade em São Paulo. Faria Lima e Água espraiada. São Paulo: Boitempo, 2001.

FURTADO, Fernanda. Instrumentos para a gestão social da valorização da terra: 
fundamentação, caracterização e desafios. In: CESARE, Claudis M. De, CUNHA, Eglaísa Micheline Pontes (coord.). Programa Nacional de Capacitação das Cidades. Financiamento das Cidades: Instrumentos Fiscais e de Política Urbana. Brasília: Ministério das Cidades, 2007, pp. 243-262.

GARCIA, Maria. Política urbana e a questão habitacional. In: Cadernos de Direito Constitucional e Ciência Política, São Paulo, v. 6, n. 22, jan./mar., 1998.

GASPARINI, Diógenes. Desapropriação. In: Boletim de direito administrativo - BDA, São Paulo, ano 20. n. 7, jul. 2004.

Global Housing Policy Indicators, Disponível em: <http://globalhousingindicators.org>. Acesso em: 15 ago. 2012.

GOMES, Daniela; SANTIN, Janaína Rigo. Estatuto da Cidade: a função social da propriedade urbana. In: Revista do Direito, Santa Cruz do Sul, n. 24, jul./dez., 2005.

GRAU, Eros Roberto. A ordem econômica na Constituição Federal de 1988. 13. ed. São Paulo: Maleiros, 2008.

Direito urbano. São Paulo: Revista dos Tribunais, 1983.

GELDER, Jean-Louis Van. Tales of Deviance and Control: On Space, Rules, and Law in Squatter Settlements. In: Law and Society Review, v.44, n.2, 2010, pp. 239-268.

HARVEY, David. A Justiça Social e a Cidade. São Paulo: Hucitec, 1980.

HOLSTON, James. Legalizando o Ilegal: propriedade e usurpação no Brasil. In: Revista Brasileira de Ciências Sociais, n. 21, ano 8, 1993, pp. .

HORBACH, Carlos Bastide. Dos Instrumentos da política urbana, Da usucapião especial urbana. Da concessão de uso especial para fins de moradia. In: ALMEIDA, Fernando Menezes de; MEDAUAR, Odete (coord.). Estatuto da Cidade - Lei $n^{o}$ 10.527, de 10.07.2001: Comentário. 2. ed. São Paulo: Malheiros, 2004.

IBGE - Base Operacional. Disponível em: <http://www.ibge.gov.br/home/presidencia/ noticias/noticia_visualiza.php?id_noticia=2051>.Acesso em: 11 jan. 2013.

JANNUZZI, Paulo de Martino. Indicadores para diagnóstico, monitoramento e avaliação de programas sociais do Brasil. In: Revista do Serviço Público, Brasília, abr./jun., 2005.

JUSTEN FILHO, Marçal. Concessões urbanísticas e outorgas onerosas. In: WAGNER JÚNIOR, Luiz Guilherme Costa (coord.). Direito público: estudos em homenagem ao professor Adilson Abreu Dallari. Belo Horizonte: Del Rey, 2004, pp. 523-539.

Curso de Direito Administrativo. 6. ed. Belo Horizonte: Editora Fórum, 2010. 
KELLAS, Hugh. Região do Grande ABC. Diadema e São Bernardo do Campo - O Projeto da Favela Naval. In: KELLAS, Hugh (org.) Inclusão, colaboração e governança urbana. Experiências brasileiras e canadenses. Coleção Limites da Cidade. Canadá: The University of British Columbia; Observatório das Metrópoles; Belo Horizonte: Editora PUC Minas, 2010, pp. 35-73.

KIM, Ricardo P. Paes. Desapropriação-sanção urbanística no Estatuto da Cidade. In: FINK, Daniel Roberto (coord.). Temas de Direito Urbanístico 4, São Paulo: Centro de Apoio Operacional de urbanismo e Meio Ambiente, Ministério Público do Estado de São Paulo e Imprensa Oficial, 2005, pp. 141-157.

KOJRANSKI, Nelson. As favelas: o desafio de sua regularização jurídica. In: Revista do Instituto dos Advogados. São Paulo, v.7, n.14, jul./dez., 2004.

LÖFSTRAND, Cecilia; THÖRN, Catharina. The Construction of Gender and Homelessness in Sweden. In: Open House International, vol. 29, n. 2, jun., 2004.

MARCOVITCH, Jacques (org.). Crescimento Econômico e Distribuição de Rendas. São Paulo: Edusp e Senac, 2007.

MARICATO, Ermínia. Brasil, cidades: alternativas para a crise urbana. Petrópolis: Editora Vozes, 2011.

MARQUES, Eduardo Cesar; BICHIR, Renata Mirandola. Estado e espaço urbano: revisitando criticamente as explicações sobre as políticas urbanas. In: Revista de Sociologia e Política, Curitiba, n.16, jun., 2001.

MARQUES NETO, Floriano de Azevedo. As parcerias público-privadas e o financiamento das infra-estruturas. In: Fórum de contratação e gestão pública, Belo Horizonte, v. 3, n. 29, mai., 2004.

.A Republicização do Estado e os Interesses Públicos. Tese de doutorado.

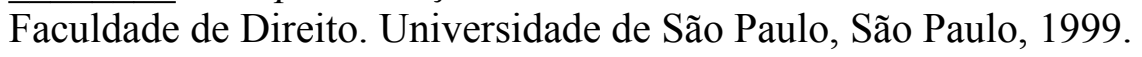

Bens Públicos: função social e exploração econômica. O regime jurídico das utilidades públicas. Belo Horizonte: Fórum, 2009.

.Os consórcios públicos. In: Revista de direito do estado - RDE, Rio de Janeiro, n. 2., abr./jun. 2006.

. Concessão de Serviço Público sem ônus para o Usuário. In: WAGNER JUNIOR, Luiz Guilherme Costa (coord.). Direito Público. Estudos em Homenagem ao Professor Adilson Abreu Dallari. Belo horizonte: Del Rey, 2004, pp. 331-351.

Contratos administrativos. In: Boletim de licitações e contratos - BLC, São Paulo, jan., v. 19, n. 1, 2006. 
Discricionariedade Administrativa e Controle Judicial da Administração. In:

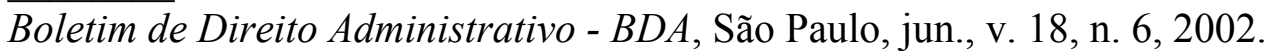

Fundamentos e conceituação das PPP. In: MARQUES NETO, Floriano de Azevedo; SCHIRATO, Vitor Rhein (coord.). Estudo Sobre a Lei das Parcerias PúblicoPrivadas. Belo Horizonte: Editora Fórum, 2011 pp. 13-29.

. Outorga Onerosa e Direito de Construir (Solo Criado). In: DALARRI, Adilson de Abreu; FERRAZ, Sérgio (coord.). Estatuto da cidade: Comentários à Lei Federal $n^{o}$ 10.257/2001. São Paulo: Malheiros, 2003, pp. 221-244.

; LOPES QUEIROZ, João Eduardo. Planejamento. In: José CARDOZO, Eduardo Martins; LOPES QUEIROZ, João Eduardo Lopes; SANTOS, Márcia Walquiria Batista dos (orgs.). Curso de Direito Administrativo Econômico. São Paulo: Malheiros, v. II, 2006, p. 40-127.

. Regulação Estatal e Interesses Públicos. São Paulo: Malheiros, 2002.

MEDAUAR, Odete. Caracteres do Direito Urbanístico. In: Revista de Direitos Difusos, São Paulo, v. 2, 2000.

. Convênios e Consórcios administrativos. In: Boletim de direito administrativo $B D A$, São Paulo, a. 11. n. 8, ago., 1995.

Destinação dos bens expropriados. São Paulo: Max Limonad, 1986.

Diretrizes Gerais. In: ALMEIDA, Fernando Dias Menezes de; MEDAUAR, Odete (coord.). Estatuto da Cidade - Lei 10.257, de 10.07.2001: Comentários. São Paulo: Revista dos Tribunais, 2004, pp. 15-40.

. O Direito Administrativo Moderno. 7. ed. São Paulo: RT, 2003.

. A processualidade no direito administrativo. 2. ed., São Paulo: Revista dos Tribunais, 2008.

MEIRELLES, Hely Lopes. Direito Administrativo Brasileiro. 21. ed. São Paulo: Malheiros, 1996.

. Direito Municipal Brasileiro. São Paulo: Malheiros, 1996.

MELlo, Celso Antônio Bandeira de. Curso de Direito Administrativo. 20. ed. São Paulo: Malheiros, 2005.

MOREIRA NETO, Diogo de Figueiredo. Introdução ao direito ecológico e ao direito urbanístico. Rio de Janeiro: Forense, 1975. 
MUKAI, Sylvio Toshiro. Constitucionalidade da concessão especial para fins de moradia. In: Fórum de Direito Urbano e Ambiental, Belo Horizonte, v. 3, n. 13, jan./fev., 2004.

NALINI, José Renato. Decisão facilita regulamentação fundiária em São Paulo. Disponível em: $\quad<$ http://www.irib.org.br/html/noticias/noticia-detalhe.php?not=1485>. Acesso em: 26 dez. 2012.

OLBERTZ, Karlin. Operação Urbana Consorciada. Belo Horizonte: Editora Fórum, 2011.

PALMA, Juliana Bonacorsi de. Atuação Administrativa Consensual: Estudo dos acordos substitutivos no processo administrativo sancionador. Dissertação de Mestrado. Faculdade de Direito. Universidade de São Paulo, São Paulo, 2010.

PASTERNAK, Suzana. Favelas e cortiços: vinte anos de pesquisa urbana no Brasil. In: Cadernos IPPUR, Rio de Janeiro, a. X, n. 2, 1996, pp. 89-115.

. Loteamentos Irregulares no Município de São Paulo: uma avaliação espacial urbanística. In: Planejamento e Políticas Públicas, Brasília, n. 34, jan/jun, 2010, pp. 131-170.

; BOGUS, Lucia Maria Machado. Moradia e segregação na cidade de São Paulo. In: Territórios, Bogotá, 2004, pp. 79-107.

PELAEZ, Leon Cortinas. Derechos humanos y urbanismo (De una axiologia constitucional vulnerada). In: Revista de Derecho Urbanistico, Madrid, v. 27, n. 131, jan./fev., 1993.

PIOVESAN, Flávia. Temas de Direitos Humanos. São Paulo: Max Limonad, 2003

REIS, José Carlos Vasconcelos dos. Os municípios no Estado federal brasileiro. In: Revista de Direito Administrativo, Rio de Janeiro, n. 228, abr./jun., 2002.

RIBEIRO, Wladimir António. Nota Técnica sobre a Legalidade e Constitucionalidade do Anteprojeto de Lei criado pela Portaria 1.391/Ccivil/2003. In: Revista Eletrônica de Direito do Estado, Salvador, Instituto de Direito Público da Bahia, n.3, jul./ago. /set., 2005. Disponível em: <http://www.direitodoestado.com.br>. Acesso em: 22 nov. 2012.

ROLNIK, Raquel. A Cidade e a Lei. 3. ed. São Paulo: FAPESP e Studio Nobel, 2003.

- Estatuto da Cidade: guia para implementação pelos nos municípios e cidadãos: Lei n.10.257, de 10 de julho de 2001, que estabelece diretrizes gerais da politica urbana. Brasília: Câmara dos Deputados, 2002.

; CARVAlHO, Celso Santos de; RIBEIRO, Sandra Bernardes Ribeiro;

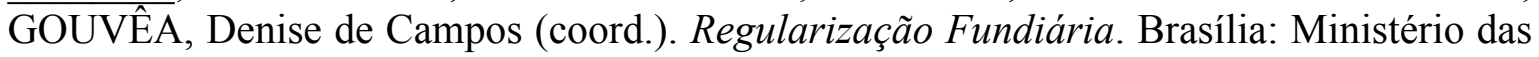
Cidades, 2005.

SARLET, Ingo Wolfgang. O Direito Fundamental à Moradia na Constituição: Algumas 
Anotações a Respeito de Seu Contexto, Conteúdo e Possível Eficácia. In: Revista Brasileira de Direito Público, Belo Horizonte, a. 1, n. 2, jul./set., 2003.

SAULE JUNIOR, Nelson. Direito Urbanístico: vias jurídicas das políticas urbanas. Porto Alegre: Sergio Antonio Fabris Editor, 2007.

. A proteção jurídica da moradia nos assentamentos irregulares. Porto Alegre: Sergio Antonio Fabris Editor, 2004.

SALLES, Venício Antônio de Paula. Regularização fundiária. In: ROLNIK, Raquel (org.), Regularização fundiária sustentável - conceitos e diretrizes, Brasília: Ministério das Cidades, 2007, pp. 130-188.

SCHECHINGER, Carlos Morales. Alguns peculiaridades del mercado de suelo urbano. Texto preparado para o curso de educação a distância: Mercados de Solo em Cidades Latino Americanas, mar., 2005.

- Notas sobre la regulación del mercado de suelo y sus instrumentos. Texto preparado para o curso de educação a distância: Mercados de Solo em Cidades Latino americanas, março, 2005.

SANCHS, Céline. São Paulo: Políticas Públicas e Habitação Popular. São Paulo: Edusp, 1999.

SCHIRATO, Vitor Rhein. A noção de serviço público nas parcerias público-privadas. In: Revista de Direito Público da Economia RDPE, Belo Horizonte, a. 5, n. 20, pp. 219-235, out./dez. 2007. Disponível em: <http://www.bidforum.com.br/bid/PDI0006.aspx?pdiCntd= 49825>. Acesso em: 02 jul. 2012.

SILVA, Danilo Tavares da. Licitação na Lei $\mathrm{n}^{0}$ 11.074/04. In MARQUE NETO, Floriano de Azevedo; SCHIRATO, Vitor Rhein (coord.). Estudo Sobre a Lei das Parcerias Público-Privadas. Belo Horizonte: Editora Fórum, 2011, pp. 71-96.

SILVA, José Afonso da. Aplicabilidade das normas constitucionais. 8. ed. São Paulo: Malheiros, 2012

. Curso de Direito Constitucional Positivo. 20. ed. São Paulo: Malheiros, 2001.

Direito Urbanístico Brasileiro. São Paulo: Editora Revista dos Tribunais, 1981.

SILVA, José Marcelo Tossi. Regularização fundiária: decisões e normas da E. Corregedoria Geral da Justiça do Estado de São Paulo. In: Revista de Direito Imobiliário. São Paulo. v. 28, n. 58, jan./jun., 2005.

SINGER, Paul. Economia política da urbanização. São Paulo: Brasiliense, 1979. 
SMOLKA, Martim O. Regularização da ocupação do solo urbano: a solução que é parte do problema, o problema que é parte da solução. In: AFONSIN, Betânia; FERNANDES, Edésio (orgs.). A Lei e a ilegalidade na produção do espaço urbano. Belo Horizonte: Del Rey; Cambridge: Lincon Institute of Land Policy, 2003, pp. 87-117.

SOUZA, Celina. Regiões Motropolitanas: trajetória e influência das escolhas institucionais. In: RIBEIRO, Luiz Cesar de Queiroz (org.) Metrópoles: entre a coesão e a fragmentação, a cooperação e o conflito. Fundação Perseu Abramo /FASE /Observatório das Metrópolis, 2004, pp.61-96.

SPINAZZOLA, Patrícia Cezário Silva. Impactos da Regularização Fundiária no Espaço Urbano. Dissertação de mestrado. Faculdade de Arquitetura e Urbanismo. Universidade de São Paulo, São Paulo, 2008.

SUNDFELD, Carlos Ari. O Estatuto da Cidade e suas diretrizes gerais. In: DALARRI, Adilson de Abreu; FERRAZ, Sérgio (coord.). Estatuto da cidade: Comentários à Lei Federal $n^{o}$ 10.257/2001. São Paulo: Malheiros, 2003, pp. 44-60.

TAVARES, José de Farias. Estatuto da Cidade e o sistema jurídico nacional. In: Revista de Direito Constitucional e Internacional, São Paulo, v. 14, n. 56, jul./set., 2006.

VICHI, Bruno de Souza. Política Urbana: Sentido jurídico, competências e responsabilidades. Belo Horizonte: Fórum, 2007.

WAGNER JÚNIOR, Luiz Guilherme Costa (coord.). Direito público: estudos em homenagem ao professor Adilson Abreu Dallari. Belo Horizonte: Del Rey, 2004.

WARD, Peter M. Foro internacional sobre regularización y mercados de la tierra. In: SMOLKA, Martim O., MULLAHY, Laura (editores). Perpectivas Urbanas: temas criticos en políticas de suelo en América Latina, Cambridge: Lincoln Institute of Land Policy, 2007, pp. 98-105.

\section{Legislação}

BRASIL. Constituição da República Federativa do Brasil de 1988. Brasília, 1988. Disponível em: <http://www.planalto.gov.br/ccivil_03/constituicao/constituicao.htm>. Acesso em: 15 dez. 2012.

BRASIL. Decreto n. 4.403, de 22 de dezembro de 1921. Regula a locação dos predios urbanos e dá outras providencias. Rio de Janeiro, 1921. Disponível em: < http://www2.camara.leg.br/legin/fed/decret/1920-1929/decreto-4403-22-dezembro-1921569624-publicacaooriginal-92854-pl.html>. Acesso em: 10 set. 2012. 
BRASIL. Decreto-Lei n. 58, de 10 de dezembro de 1937. Dispôe sôbre o loteamento e a venda de terrenos para pagamento em prestações. Rio de Janeiro, 1937. Disponível em: < http://www.planalto.gov.br/ccivil_03/decreto-lei/1937-1946/Del058.htm>. Acesso em: 11 set. 2012.

BRASIL. Decreto-Lei n. 3.365, de 21 de junho de 1941. Dispõe sobre desapropriações por utilidade pública. Brasília, 1941. Disponível em: $<$ http://www.planalto.gov.br/ccivil_03/decreto-lei/del3365.htm>. Acesso em: 20 out. 2012.

BRASIL. Decreto-Lei n. 9.218, de $1^{\circ}$ de maio de 1946. Autoriza a instituição da "Fundação da Casa Popular". Rio de Janeiro, 1946. Disponível em: < http://www2.camara.leg.br/legin/fed/declei/1940-1949/decreto-lei-9218-1-maio-1946417087-publicacaooriginal-1-pe.html >. Acesso em: 10 set. 2012.

BRASIL. Decreto-Lei n. 9.760, de 5 de setembro de 1946. Dispõe sôbre os bens imóveis da União e dá outras providências. Brasília, 1946. Disponível em: $<$ http://www.planalto.gov.br/ccivil_03/decreto-lei/de19760.htm>. Acesso em: 13 out. 2012.

BRASIL. Decreto-Lei n. 271, de 28 de fevereio de 1967. Dispõe sôbre loteamento urbano, responsabilidade do loteador concessão de uso e espaço aéreo e dá outras providências. Brasília, 1967. Disponível em: <http://www.planalto.gov.br/ccivil_03/decretolei/del0271.htm>. Acesso em: 15 set. 2012.

BRASIL. Decreto-Lei n. 1.876, de 15 de julho de 1981. Dispensa do pagamento de foros e laudêmios os titulares do domínio útil dos bens imóveis da União, nos casos que especifica, e dá outras providência. Brasília, 1981. Disponível em: $<$ http://www.planalto.gov.br/ccivil_03/decreto-lei/1965-1988/Del1876.htm>. Acesso em: 20 out. 2012.

BRASIL. Emenda Constitucional n. 26, de 14 de fevereiro de 2000. Altera a redação do art. $6^{\circ}$ da Constituição Federal. Brasília, 2000. Disponível em: $<$ http://www.planalto.gov.br/ccivil_03/constituicao/Emendas/Emc/emc26.htm>. Acesso em: 8 ago. 2012.

BRASIL. Instrução CVM n. 401, de 29 de dezembro de 2003. Dispõe sobre os registros de negociação e de distribuição pública de Certificados de Potencial Adicional de Construção - CEPAC. $2003 . \quad$ Brasília, Disponível em: $<$ http://www.cvm.gov.br/asp/cvmwww/atos/exiato.asp?file=linstlinst401.htm>. Acesso em: 23 nov. 2012.

BRASIL. Lei n. 601, de 18 de setembro de 1850. Dispõe sobre as terras devolutas do Império. Rio de Janeiro, $1850 . \quad$ Disponível em: $<$ http://www.planalto.gov.br/ccivil_03/Leis/L0601-1850.htm>. Acesso em: 22 dez. 2012.

BRASIL. Lei n. 4.132, de 10 de setembro de 1962. Define os casos de desapropriação por interesse social e dispõe sobre sua aplicação. Brasília, 1962. Disponível em: $<$ http://www.planalto.gov.br/ccivil_03/leis/L4132.htm >. Acesso em: 18 out. 2012. 
BRASIL. Lei n. 4.380, de 21 de agosto de 1964. Institui a correção monetária nos contratos imobiliários de interêsse social, o sistema financeiro para aquisição da casa própria, cria o Banco Nacional da Habitação (BNH), e Sociedades de Crédito Imobiliário, as Letras Imobiliárias, o Serviço Federal de Habitação e Urbanismo e dá outras providências. Brasília, $1964 . \quad$ Disponível em: $<$ http://www.planalto.gov.br/ccivil_03/leis/L4380.htm>. Acesso em: 25 out. 2012.

BRASIL. Lei n. 6.015, de 31 de dezembro de 1973. Dispõe sobre os registros públicos, e dá outras providências. Brasília, 1973. Disponível em: $<$ http://www.planalto.gov.br/ccivil_03/leis/L6015.htm>. Acesso em: 28 out. 2012.

BRASIL. Lei n. 6.766, de 19 de setembro de 1979. Dispõe sobre o Parcelamento do Solo Urbano e dá outras providências. Brasília, 1979. Disponível em: $<$ http://www.planalto.gov.br/ccivil_03/leis/L6766.htm>. Acesso em: 9 dez. 2012.

BRASIL. Lei n. 8.080, de 19 de setembro de 1990. Dispõe sobre as condições para a promoção, proteção e recuperação da saúde, a organização e o funcionamento dos serviços correspondentes e dá outras providências. Brasília, 1990. Disponível em: < http://www.planalto.gov.br/ccivil_03/leis/L8080.htm>. Acesso em: 14 dez. 2012.

BRASIL. Lei n. 8.666, de 21 de junho de 1993. Regulamenta o art. 37, inciso XXI, da Constituição Federal, institui normas para licitações e contratos da Administração Pública e dá outras providências. Brasília, 1993. Disponível em: < http://www.planalto.gov.br/ccivil_03/leis/L8666cons.htm >. Acesso em: 5 dez. 2012.

BRASIL. Lei n. 8.987, de 13 de fevereiro de 1995. Dispõe sobre o regime de concessão e permissão da prestação de serviços públicos previsto no art. 175 da Constituição Federal e dá outras providências. Brasília, 1995. Disponível em: <http://www.planalto.gov.br/ccivil_03/leis/L8987cons.htm>. Acesso em: 7 dez. 2012.

BRASIL. Lei n. 9.636, de 15 de maio de 1998. Dispõe sobre a regularização, administração, aforamento e alienação de bens imóveis de domínio da União altera dispositivos dos Decretos-Leis $\mathrm{n}^{\text {os }}$ 9.760, de 5 de setembro de 1946, e 2.398, de 21 de dezembro de 1987, regulamenta o $§ 2^{\circ}$ do art. 49 do Ato das Disposições Constitucionais Transitórias, e dá outras providências. Brasília, 1998. Disponível em: $<$ http://www.planalto.gov.br/ccivil_03/leis/L9636.htm>. Acesso em: 27 set. 2012.

BRASIL. Lei n. 9.637, de 15 de maio de 1998. Dispõe sobre a qualificação de entidades como organizações sociais, a criação do Programa Nacional de Publicização, a extinção dos órgãos e entidades que menciona e a absorção de suas atividades por organizações sociais e dá outras providências. Brasília, 1998. Disponível em: $<$ http://www.planalto.gov.br/ccivil_03/leis/L9637.htm>. Acesso em: 14 nov. 2012.

BRASIL. Lei n. 9.790, de 23 de março de 1999. Dispõe sobre a qualificação de pessoas jurídicas de direito privado, sem fins lucrativos, como Organizações da Sociedade Civil de Interesse Público, institui e disciplina o Termo de Parceria, e dá outras providências.. Brasília, 1999. Disponível em: <http://www.planalto.gov.br/ccivil_03/leis/L6766.htm>. Acesso em: 14 nov. 2012. 
BRASIL. Lei n. 9.785, de 29 de janeiro de 1999. Altera o Decreto-Lei $\mathrm{n}^{0} 3.365$, de 21 de junho de 1941 (desapropriação por utilidade pública) e as Leis $\mathrm{n}^{\mathrm{os}} 6.015$, de 31 de dezembro de 1973 (registros públicos) e 6.766, de 19 de dezembro de 1979 (parcelamento do solo urbano). Brasília, 1999. Disponível em: $<$ http://www.planalto.gov.br/ccivil_03/leis/L9785.htm>. Acesso em: 21 out. 2012.

BRASIL. Lei n. 10.257, de $1^{\circ}$ de julho de 2001. Regulamenta os arts. 182 e 183 da Constituição Federal, estabelece diretrizes gerais da política urbana e dá outras providências. Brasília, 2001. Disponível em: $<$ http://www.planalto.gov.br/ccivil_03/leis/LEIS_2001/L10257.htm>. Acesso em: 16 dez. 2012.

BRASIL. Lei n. 10.406, de 10 de janeiro de 2002. Institui o Código Civil. Brasília, 1979. Disponível em: < http://www.planalto.gov.br/ccivil_03/leis/2002/L10406.htm>. Acesso em: 20 dez. 2012.

BRASIL. Lei n. 11.079, de 30 de dezembro de 2005. Institui normas gerais para licitação e contratação de parceria público-privada no âmbito da administração pública. Brasília, 2005. Disponível em: <http://www.planalto.gov.br/ccivil_03/_ato20042006/2004/lei/111079.htm>. Acesso em: 30 nov. 2012.

BRASIL. Lei n. 11.107, de 6 de abril de 2005. Dispõe sobre normas gerais de contratação de consórcios públicos e dá outras providências. Brasília, 2005. Disponível em: $<$ http://www.planalto.gov.br/ccivil_03/_ato2004-2006/2005/Lei/L11107.htm>. Acesso em: 19 nov. 2012.

BRASIL. Lei n. 11.124, de 16 de junho de 2005. Dispõe sobre o Sistema Nacional de Habitação de Interesse Social - SNHIS, cria o Fundo Nacional de Habitação de Interesse Social - FNHIS e institui o Conselho Gestor do FNHIS. Brasília, 2005. Disponível em: < http://www.planalto.gov.br/ccivil_03/_ato2004-2006/2005/lei/111124.htm>. Acesso em: 12 nov. 2012.

BRASIL. Lei n. 11.481, de 31 de maio de 2007. Dá nova redação a dispositivos das Leis $\mathrm{n}^{\text {os }}$ 9.636, de 15 de maio de 1998, 8.666, de 21 de junho de 1993, 11.124, de 16 de junho de 2005, 10.406, de 10 de janeiro de 2002 - Código Civil, 9.514, de 20 de novembro de 1997, e 6.015, de 31 de dezembro de 1973, e dos Decretos-Leis ${ }^{\text {os }} 9.760$, de 5 de setembro de 1946, 271, de 28 de fevereiro de 1967, 1.876, de 15 de julho de 1981, e 2.398, de 21 de dezembro de 1987; prevê medidas voltadas à regularização fundiária de interesse social em imóveis da União; e dá outras providências. Brasília, 2007. Disponível em: < http://www.planalto.gov.br/ccivil_03/_ato2007-2010/2007/Lei/L11481.htm>. Acesso em: 27 set. 2012.

BRASIL. Lei n. 11.578, de 26 de novembro de 2007. Dispõe sobre a transferência obrigatória de recursos financeiros para a execução pelos Estados, Distrito Federal e Municípios de ações do Programa de Aceleração do Crescimento - PAC, e sobre a forma de operacionalização do Programa de Subsídio à Habitação de Interesse Social - PSH nos exercícios de 2007 e 2008. Brasília, 2007. Disponível em: $<$ http://www.planalto.gov.br/ccivil_03/_ato2007-2010/2007/Lei/L11578.htm>. Acesso em: 
12 nov. 2012.

BRASIL. Lei n. 11.952, de 25 de junho de 2009. Dispõe sobre a regularização fundiária das ocupações incidentes em terras situadas em áreas da União, no âmbito da Amazônia Legal; altera as Leis $\mathrm{n}^{\mathrm{os}}$ 8.666, de 21 de junho de 1993, e 6.015, de 31 de dezembro de 1973; e dá outras providências. Brasília, 2009. Disponível em: < http://www.planalto.gov.br/ccivil_03/_ato2007-2010/2009/lei/111952.htm>. Acesso em: 27 set. 2012 .

BRASIL. Lei n. 11.977, de 7 de julho de 2009. Dispõe sobre o Programa Minha Casa, Minha Vida - PMCMV e a regularização fundiária de assentamentos localizados em áreas urbanas; altera o Decreto-Lei $\mathrm{n}^{\mathrm{o}} 3.365$, de 21 de junho de 1941, as Leis $\mathrm{n}^{\text {os }} 4.380$, de 21 de agosto de 1964, 6.015 de 31 de setembro de 1973, 8.036 de 11 de maio de 1990, 10.257, de 10 de julho de 2001 e a Medida Provisória ${ }^{0} 2.197-43$ de 24 de agosto de 2001; e dá outras providências. Brasília, 2009. Disponível em: $<$ http://www.planalto.gov.br/ccivil_03/_ato2007-2010/2009/lei/111977.htm>. Acesso em: 15 dez. 2012.

BRASIL. Lei n. 12.424, de 16 de junho de 2011. Altera a Lei no 11.977, de 7 de julho de 2009, que dispõe sobre o Programa Minha Casa, Minha Vida - PMCMV e a regularização fundiária de assentamentos localizados em áreas urbanas, as Leis nos 10.188, de 12 de fevereiro de 2001, 6.015, de 31 de dezembro de 1973, 6.766, de 19 de dezembro de 1979, 4.591, de 16 de dezembro de 1964, 8.212, de 24 de julho de 1991, e 10.406, de 10 de janeiro de 2002 - Código Civil; revoga dispositivos da Medida Provisória no 2.197-43, de 24 de agosto de 2001; e dá outras providências. Brasília, 2011. Disponível em: < http://www.planalto.gov.br/ccivil_03/_ato2011-2014/2011/Lei/L12424.htm>. Acesso em: 15 dez. 2012.

BRASIL. Lei n. 12.651, de 25 de maio de 2012. Dispõe sobre a proteção da vegetação nativa; altera as Leis $\mathrm{n}^{\mathrm{os}}$ 6.938, de 31 de agosto de 1981, 9.393 de 19 de dezembro de 1996, e 11.428, de 22 de dezembro de 2006; revoga as Leis $\mathrm{n}^{\mathrm{os}} 4.771$, de 15 de setembro de 1965, e 7.754, de 14 de abril de 1989, e a Medida Provisória no ${ }^{-2.166-67, ~ d e ~} 24$ de agosto de 2001; e dá outras providências. Brasília, 2012. Disponível em: $<$ http://www.planalto.gov.br/ccivil_03/_Ato2011-2014/2012/Lei/L12651.htm>. Acesso em: 18 out. 2012.

BRASIL. Medida Provisória n. 2.220, de 4 de setembro de 2001. Dispõe sobre a concessão de uso especial de que trata o $\S 1^{\circ}$ do art. 183 da Constituição, cria o Conselho Nacional de Desenvolvimento Urbano - CNDU e dá outras providências. Brasília, 2001. Disponível em: < http://www.planalto.gov.br/ccivil_03/mpv/2220.htm>. Acesso em: 10 out. 2012.

MATO GROSSO DO SUL (Estado). Constituição do Estado. Campo Grande, 1989. Disponível em: <http://www2.senado.gov.br/bdsf/item/id/70445>. Acesso em: $18 \mathrm{dez}$. 2012.

MINAS GERAIS (Estado). Constituição do Estado. Belo Horizonte, 1989. Disponível em: $<$ http://www.tce.mg.gov.br/index.asp?cod_secao $=7 \mathrm{H} \&$ tipo $=1 \& u r l=\& \operatorname{cod} \_s e c a o \_m e n u=5 \mathrm{~L}$ >. Acesso em: 18 dez. 2012. 
PERNAMBUCO. Constituição do Estado. Recife, 1989. Disponível em: $<$ http://www.pe.gov.br/conheca/constituicao/>. Acesso em: $18 \mathrm{dez} .2012$.

PORTO ALEGRE (Município). Lei Orgânica. Porto Alegre, 1990. Disponível em: $<$ http://www.camarapoa.rs.gov.br/biblioteca/lei_org/LEI\%20ORG\%C3\%82NICA.html $>$. Acesso em: 18 dez. 2012.

PORTO ALEGRE (Município). Decreto n. 14.428, de 2 de janeiro de 2004. Regulamenta a Lei $\mathrm{n}^{\mathrm{o}}$ 9.162/03, que dispõe sobre a parceria da Administração Municipal com os empreendedores considerados urbanizadores sociais. Porto Alegre, 2004. Disponível em: $<$ http://www2.portoalegre.rs.gov.br/cgi-bin/nph-

brs? $1=000026038 . \mathrm{DOCN} . \& \mathrm{l}=20 \& \mathrm{u}=/$ netahtml $/$ sirel $/$ simples.html $\& \mathrm{p}=1 \& \mathrm{r}=1 \& \mathrm{f}=\mathrm{G} \& \mathrm{~d}=$ ato s\&SECT1=TEXT>. Acesso em: 6 dez. 2012.

PORTO ALEGRE (Município). Lei n. 9.162, de 8 de julho de 2003. Regulamenta os $\S \S 3^{\circ}$ e $4^{\circ}$ do art. 76 da Lei Complementar $n^{\circ} 434$, de $1^{\circ}$ de dezembro de 1999, dispondo sobre a parceria da Administração Municipal com os empreendedores considerados urbanizadores sociais. Porto Alegre, 2003. Disponível em: <http://www2.portoalegre.rs.gov.br/cgibin/nph-

brs?s1 $=000025602 . D O C N . \& l=20 \& u=/$ netahtml $/$ sirel $/$ simples.html $\& p=1 \& r=1 \& f=G \& d=$ ato s\&SECT1=TEXT>. Acesso em: 6 dez. 2012.

RIO DE JANEIRO (Município). Lei Orgânica. Rio de Janeiro, 1990. Disponível em: $<$ http://www.leismunicipais.com.br/lei-organica/riodejaneiro-rj/3613>. Acesso em: 28 dez. 2012.

SÃO PAULO (Estado). Constituição do Estado. São Paulo, 1989. Disponível em: $<$ http://www.al.sp.gov.br/repositorio/legislacao/constituicao/1989/constituicao\%20de $\% 200$ 5.10.1989.htm>. Acesso em: 18 dez. 2012.

SÃO PAULO (Município). Lei Orgânica. São Paulo, 1990. Disponível em: $<$ http://www.prefeitura.sp.gov.br/cidade/secretarias/educacao/cme/legislacao/index.php?p= 439>. Acesso em: 18 dez. 2012. 